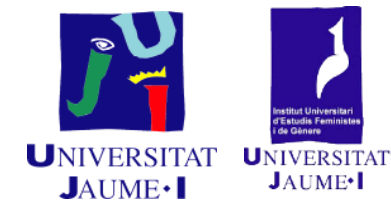

UNIVERSITAT JAUME I

FACULTAD DE CIENCIAS HUMANAS Y SOCIALES

INSTITUTO UNIVERSITARIO DE ESTUDIOS FEMINISTAS Y DE GÉNERO

«PURIFICACIÓN ESCRIBANO»

PROGRAMA DE DOCTORADO ESTUDIOS SOBRE LAS MUJERES,

FEMINISTAS Y DE GÉNERO

\title{
ALICIA GIMÉNEZ BARTLETT Y MERCEDES CASTRO. DIFERENTES FORMAS DE APROXIMARSE A LA NOVELA NEGRA DESDE UNA PERSPECTIVA DE GÉNERO
}

TESIS DOCTORAL

Presentada por: Dori Valero Valero

Dirigida por: Dora Sales Salvador 



\section{AGRADECIMIENTOS}

En primer lugar, mi más profundo agradecimiento a mi madre, Dora, y a mi padre, Juan, porque sin ellos esta tesis seguro que no estaría hecha. A mi hermana, Mar, porque siempre me anima a seguir adelante.

A mis compañeras del Instituto Universitario de Estudios Feministas y de Género «Purificación Escribano» por las sugerencias y la información que me han facilitado para la investigación.

A Inma Alcalá, empezamos el camino juntas y lo hemos acabado a la vez. ¡Lo hemos conseguido!

A José Manuel por todos sus sabios consejos.

A las amigas y amigos por su apoyo y ánimos en todo momento. $\mathrm{Y}$ a todas las personas que han mostrado interés en esta tesis.

Y muchas gracias a mi directora de tesis, Dora Sales Salvador, por la paciencia y la disponibilidad que siempre me ha prestado, y porque siempre ha estado ahí para resolver cualquier duda.

No quiero olvidar, para acabar, dar las gracias a todas las mujeres que han trabajado para que yo pueda estar aquí y tenga una voz propia. 

Índice

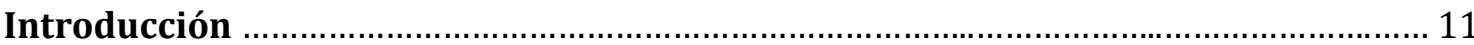

CAPÍTULO 1. El origen y desarrollo de la novela negra ................................................ 21

1.1. Origen de la novela negra: el relato enigma .................................................... 26

1.2. Hard-boiled: la evolución estadounidense del género negro ............................... 41

1.3. Novela negra desde mediados del siglo XX hasta la actualidad ........................... 55

1.4. Aproximación a las novelas negras periféricas. El caso de la novela negra japonesa, la novela negra africana y la novela negra de la India ............................... 63

1.5. Mujeres escritoras. Una forma diferente de entender la literatura .................... 68

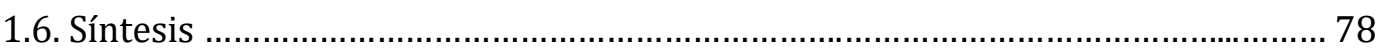

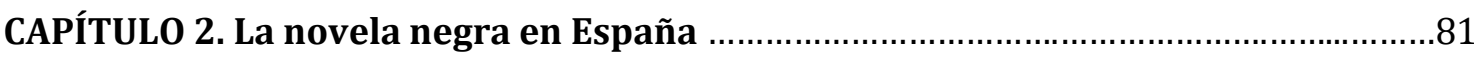

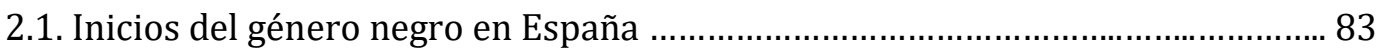

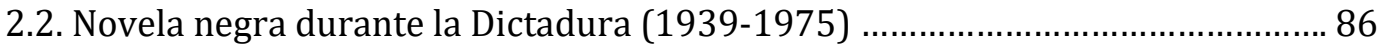

2.3. Novela negra durante la Transición (1975-1982)

2.4. La novela negra contemporánea en España......................................................94

2.5. Aproximación a las novelas negras periféricas en España................................. 105

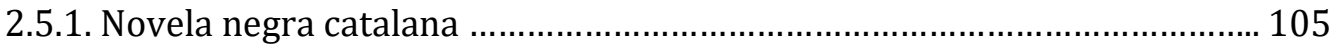

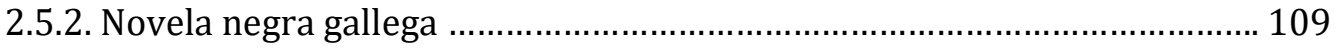

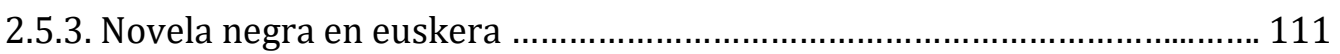

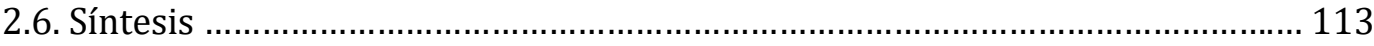

CAPÍTULO 3. Alicia Giménez Bartlett y Mercedes Castro: dos formas de entender la novela negra protagonizada por mujeres ……….................................................... 117

3.1. Alicia Giménez Bartlett ............................................................................... 126 
3.1.1. Alicia Giménez Bartlett: escritora

3.1.2. La saga de Petra Delicado: personajes

3.1.3. La saga de Petra Delicado: sus crímenes 132

3.2. Mercedes Castro 138

3.2.1. Mercedes Castro: escritora 138

3.2.2. Y punto y Mantis: personajes 139

3.2.3. Y punto y Mantis: sus crímenes 142

3.3. Síntesis 144

\section{CAPÍTULO 4. Construcción de nuevos modelos de representación de las mujeres en} la novela negra española actual desde una perspectiva de género 145

4.1. Protagonistas femeninas de la novela negra española actual desde una perspectiva de género 148

4.1.1. Mujeres profesionales: Petra Delicado, Clara Deza y Teresa Sinde 161

4.1.2. Masculinización vs feminización en la representación de las protagonistas 184

4.1.3. Representación de la maternidad en Alicia Giménez Bartlett y Mercedes Castro 199

4.1.4. Representación de las relaciones de los personajes femeninos en Alicia Giménez Bartlett y Mercedes Castro 216

4.1.5. Representación de la violencia de género: de la agresión física a los micromachismos 221

4.1.6. Representación de la sexualidad de las protagonistas en las novelas de Alicia Giménez Bartlett y Mercedes Castro 229 


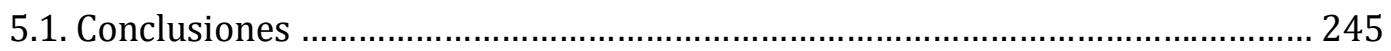

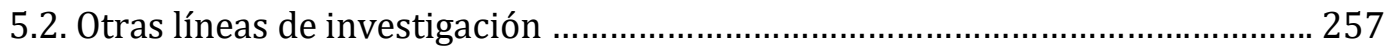

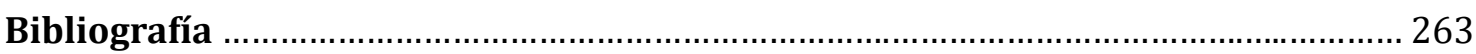

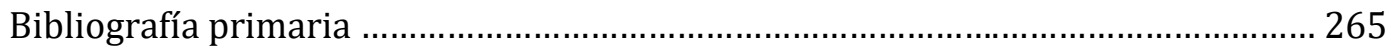

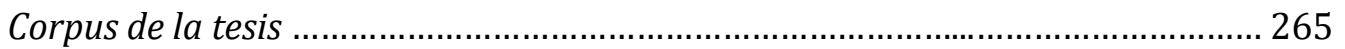

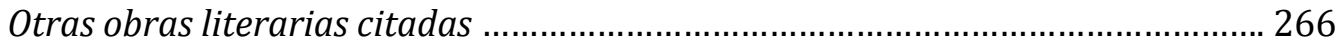

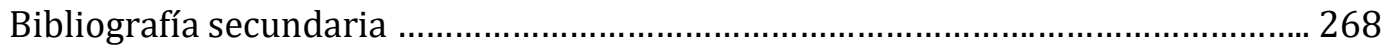

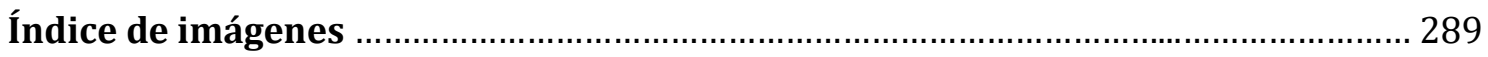







\section{Introducción}

La novela negra es, desde su origen, un género literario que goza de gran popularidad, a pesar de que parte de la crítica textual la considera un género menor. El origen del género lo situamos, siguiendo el consenso general al respecto en la publicación de «Los crímenes de la calle Morgue» (1841), de Edgar Allan Poe. Una narración que establece algunas de las características que se consolidarán como configuradoras de la novela enigma. El momento histórico en el que se produce la aparición de este nuevo género se sitúa a mediados del siglo XIX, porque se dan las condiciones socioeconómico-políticas para el surgimiento de este nuevo tipo de literatura. Es cierto que existen narraciones anteriores a este cuento, entre policiaco y terrorífico, que presentan algunas de las características del género negro, sin embargo, entendemos este primer «subgénero» como un género más próximo a los relatos de misterio.

La popularidad a la que nos referimos, y a pesar de su consideración de género menor, hace que se hayan realizado múltiples investigaciones sobre su estructura narrativa, la historiografía de su género, los autores y autoras más relevantes que han asentado el género, incluso se han tratado autores del género españoles y en los últimos años se añaden nombres de autoras españolas, especialmente desde 2000 hasta la actualidad. Sin embargo, estos análisis se han venido realizando desde una óptica investigadora dominante, sin dejar espacio a revisiones, a nuestro juicio más adecuadas, como son la teoría crítica feminista.

En un mundo cambiante, desde la década de los sesenta del siglo XX (en España los ochenta) las mujeres han ido conquistando espacios que les permiten asumir diferentes formas de relacionarse con este mundo. La conquista de los derechos laborales, los derechos sexuales y reproductivos, los derechos políticos, etc., aunque todavía quede mucho camino por recorrer para llegar a una igualdad completa, dan la oportunidad a las mujeres para expresar sus deseos, necesidades y vivencias con una voz propia, y esto debería cambiar su representación en las 
diferentes formas artísticas ${ }^{1}$ ¿ ¿Se aprecia el protagonismo de las mujeres en estas novelas? ¿Las autoras crean nuevos modelos femeninos? ¿Los modelos de feminidad son asimilados a los modelos tradicionales de masculinidad? Estas son sólo algunas de las cuestiones que nos planteamos para ayudarnos a responder a los objetivos planteados en esta tesis.

El objetivo inicial es identificar los modelos de mujeres que aparecen en novelas negras contemporáneas, en novelas de escritoras españolas que están publicando actualmente (de 2010-2016, periodo de realización de esta tesis). Entendiendo la novela negra como novela eminentemente social, queremos desvelar modelos femeninos, si existen, que surgen de «nuevos» referentes sociales, pues siguiendo a Paco Ignacio Taibo II consideramos que «una novela negra es aquella que tiene en su corazón un hecho criminal y que genera una investigación. Lo que ocurre es que una buena novela negra investiga algo más que quién mató o quién cometió el delito, investiga a la sociedad en la que los hechos se producen. Empieza contando un crimen, y termina contando cómo es esa sociedad» (Taibo en Salados, 1 de julio de 2000: 26-27).

La novela policiaca que evoluciona convive con la novela negra que siempre ha contado con mujeres tanto como escritoras como entre sus personajes. Sin embargo, estos personajes femeninos no se diferenciaban demasiado de los personajes masculinos del género. ¿Qué diferencia hay entre Miss Marple, una anciana con extraordinarias dotes de observación, y Sherlock Holmes, un cocainómano superdotado? Pongamos un ejemplo más claro, ¿qué diferencia hay entre los personajes de Miss Marple y Hercules Poirot? Parece que la novela policiaca centrada en el enigma tiene una estructura tan marcada que no permite generar novedades, sin embargo, la novela negra abre el abanico hasta donde quiera o llegue la imaginación de la autora o el autor (por ejemplo, Mantis (2010), de Mercedes Castro, como veremos). Hoy en día el género negro va mucho más allá de Raymond Chandler o Dashiell Hammett, por muy atrayente que resulte Sam Spade encarnado en Humphrey Bogart o la violencia extrema. Se trata de una

\footnotetext{
${ }^{1}$ Las referencias que realizamos a lo largo de la tesis, si no señalamos lo contrario, se circunscriben a las sociedades occidentales, capitalistas. Las sociedades no occidentales presentan particularidades propias derivadas de sus procesos histórico-sociales-políticoseconómicos.
} 
novela que incluye cierta diversidad desde la perspectiva de género: mujeres y homosexuales se representan como sujetos actantes más allá de ser víctimas. Por ejemplo, y sin agotar todas las posibilidades: el detective Dave Brandsletter (19701984) creado por Joseph Hansen (1923-2004), es considerado como uno de los primeros detectives de novela negra homosexuales. También encontramos la serie de Gay Flower (1978-2002), del español PGarcía, seudónimo del escritor José García Martínez Calín (1932- ), que tiene como protagonista a un detective homosexual. Más actual es el personaje de Arturo Zarco (2010 y 2012), creado por la autora Marta Sanz (1967- ). La saga de Donald Strachey (1981-2015) presenta a un agente de seguros gay que investiga diversos casos, y ha sido escrita por el autor Richard Stevenson (1938- ). Mehmet Murat Somer (1959- ) crea la primera investigadora transexual en Los crímenes del profeta (2008), la primera novela de la serie Hop-Çiki-Yaya (Turkish Delight Mystery, 2008-2014).

En cuanto a mujeres detectives destacaremos a personajes como Kinsey Millhone, protagonista de la serie El abecedario del crimen (1982-2015), de Sue Grafton (1940- ). La escritora clásica de novela negra Patricia Cornwell (1956- ) creó la serie protagonizada por la forense Kay Scarpeta (1990-2016). También destaca la serie protagonizada por Precious Ramotswe (1998-2016), de Alexander McCall Smith (1948- ), cuya primera novela lleva el revelador título de The No. 1 Ladies' Detective Agency (1998). A lo largo de la tesis analizaremos más personajes «alternativos», especialmente contemporáneos y de la novela negra española.

Así pues, nos proponemos analizar el cambio en los personajes femeninos de las novelas negras cuya transformación más evidente es el paso de femme fatale y acompañante del detective varón a protagonistas absolutas con toda su realidad. Esto significa que no sirve ya un investigador cínico y hastiado, sino que los personajes son madres, profesionales, tienen problemas cotidianos 0 inseguridades que les provocan miedos que expresan en voz alta. Pero, ¿ es cosa del género, de los personajes o es una cuestión del sexo-género de las autoras? Centrando el análisis en autoras españolas dejamos de lado otros ejemplos muy interesantes que pueden formar parte de otra investigación ${ }^{2}$. J.K. Rowling, madre

\footnotetext{
${ }^{2}$ Cada autora (y autor) contemporánea utiliza una interpretación propia de las reglas de la novela negra. La rigidez de los elementos se ha relajado y encontramos características de
} 
de Harry Potter, crea, bajo el seudónimo de Robert Galbraith, a un detective cansado del mundo, Cormoran Strike, que tras una fachada de hombre duro esconde un hombre inseguro, en parte, por la limitación física que le supone la amputación de una de sus piernas que sufrió en la guerra de Afganistán. En este caso se abre una posible línea de investigación más: ¿es Cormoran Strike un personaje representante de las nuevas masculinidades porque está escrito por una mujer o porque el género negro se centra menos en el caso y más en el contexto social cambiante en cuanto a los roles tradicionales se refiere? Éste es sólo un ejemplo de las muchas preguntas que pueden derivar en líneas de investigación que merecería la pena explorar, y que demuestran los múltiples caminos abiertos en torno a esta literatura.

El trabajo resulta complejo, ya que es complicado acceder a todo lo que se edita anualmente sobre género negro. Aunque sólo nos ciñamos a autoras españolas, en los últimos años la autoedición y las nuevas tecnologías han creado espacios con muchas posibilidades para autoras (y autores) noveles y autoras (y autores) a los que no respalda un gran grupo editorial (este tema, si bien resulta muy interesante, no lo trataremos, pues sería objeto de otra investigación posterior). Así que hemos optado por escoger autoras que por, diversos motivos, han resultado un éxito de ventas, como Alicia Giménez Bartlett, o que por las características de sus obras pueden representar alguna marca diferenciadora, es

novela negra en muchos relatos. Incluso en la serie de Harry Potter encontramos elementos «criminales». Harry intenta hacer «justicia» a sus padres, asesinados cuando él era muy pequeño. La autora, J. K. Rowling, es evidente que no estaba desarrollando una serie negra para adolescentes, a pesar de los pequeños «misterios-delitos» que el grupo de jóvenes magos resuelve en cada entrega. Sin embargo, la inquietud negra existía dentro de la escritora que desarrolla el personaje de Cormoran Strike, inquietud que se puede encontrar en otras autoras y autores, por ejemplo: María Dueñas y su novela históricoromántica de espías, El tiempo entre costuras (2009). Este fenómeno no es nuevo, P.D. James (2009 [2010]) afirma: «Emma de Jane Austen tal vez sea el más interesante de los ejemplos de la llamada literatura mainstream (es decir, la que no es de género) que es al mismo tiempo una historia de detectives con una excelente estructura. En esta novela, el secreto en torno al cual gira la acción son las veladas relaciones entre un reducido número de personajes. La historia transcurre en la cerrada sociedad de un contexto rural, algo que tiempo más tarde se convertiría en lugar común en las novelas detectivescas, y Jane Austen nos engaña mediante pistas ingeniosamente elaboradas (de entrada me vienen a la cabeza ocho), algunas basadas en la acción, otras en conversaciones en apariencia insustanciales y otra aún en la voz del narrador. Al final, cuando todo se aclara y los personajes se unen con sus correspondientes parejas, nos preguntamos cómo podríamos estar tan engañados» (James, 2009 [2010]: 7- 8). 
decir, nos sirven como «grupo de control», como es Mercedes Castro. Añadiremos, como elemento comparador, alguna autora o autor que nos ayudará a ahondar en la tesis que planteamos, bien por sus coincidencias o discrepancias con las escritoras que estudiamos, como Dolores Redondo (2013a, 2013b, 2014, 2016), que ha supuesto uno de los éxitos más rotundos en los últimos años, o José María Guelbenzu (2001), que introduce a una jueza como personaje central de su serie sobre Mariana de Marco.

Nuestro análisis pondrá el foco sobre el personaje protagonista, siempre un personaje femenino, y el tipo de relaciones que establece con su entorno. Pero debemos tener en cuenta que éste es un trabajo vivo que crece y muta. Mientras lo escribíamos se han producido nuevos avances: Dolores Redondo, cuya Trilogía del Baztán (2013-2014) ha vendido más de 700.000 ejemplares, ha ganado el premio Planeta 2016. Robert Galbraith también ha publicado el tercer título de su serie de Cormoran Strike (2013-2015). Una autora de novela fantástica muy conocida en Estados Unidos, como Inés García Sáez de Urturi (2016), se ha estrenado en el género negro, con una novela de «control» que nos va a permitir verificar alguno de nuestros presupuestos. Clara Peñalver ha dado por concluida momentáneamente su serie de Ada Levy (2013-2016) y el movimiento no cesa en torno al género que nos ocupa.

La metodología que empleamos se centra en el análisis crítico de los personajes femeninos principales de la saga de Petra Delicado (1996-2015) y las dos novelas de Mercedes Castro, Y punto (2008) y Mantis (2010): Petra Delicado, Clara Deza y Teresa Sinde. Para ello examinaremos la construcción de estos personajes en lo referente a aspectos como sus relaciones profesionales, la maternidad, las relaciones con otras mujeres tanto en el ámbito laboral como personal, la visibilidad que se le da a la violencia de género o la sexualización de estos personajes desde la perspectiva de los estudios de género.

La tesis la hemos estructurado de lo general a lo particular, es decir, hemos empezado por contextualizar de manera resumida la evolución de la novela negra para acto seguido analizar los modelos de mujer que presentan dos autoras concretas, Alicia Giménez Bartlett, con Petra Delicado, y Mercedes Castro, con Clara 
Deza y Teresa Sinde. A tal efecto, hemos estructurado nuestra investigación en cinco capítulos.

El primer capítulo, El origen y desarrollo de la novela negra, revisa de forma diacrónica, histórica, el desarrollo del género desde sus orígenes hasta nuestros días, señalando las características generales que han compuesto cada una de las etapas: novela enigma, hard-boiled, suspense, formas contemporáneas de la novela negra, etc. Además, se señala la situación actual de las influencias de la novela negra que contribuyen a la española y algunas literaturas periféricas que conforman el nuevo género negro, buscando algunos nombres femeninos que pueden ser de interés para el análisis, bien porque las autoras han confesado que se han sentido influidas por ellos, bien porque forman parte del imaginario colectivo y, por lo tanto, influyen en la construcción de los personajes.

El segundo capítulo, La novela negra en España, se centra en lo que ha sido el nacimiento y escaso desarrollo de la novela policiaca y negra española. Una novela que no destacó, por cuestiones políticas, hasta la Transición y el principio de la democracia. En este caso, iniciamos la revisión con Joaquín Belda y nos detenemos brevemente en Emilia Pardo Bazán, para continuar con lo que sucedió con el género negro durante la Guerra Civil y la Dictadura. Así llegamos hasta la presentación del personaje por antonomasia de la novela negra en España, Pepe Carvalho y el gran referente español del género, su autor, Manuel Vázquez Montalbán. Seguidamente, planteamos qué está sucediendo en la actualidad.

También realizamos una aproximación a lo que han sido las novelas negras periféricas en España: novela negra en catalán, novela negra en gallego y novela negra en euskera.

El tercer capítulo, Alicia Giménez Bartlett y Mercedes Castro: dos formas de entender la novela negra protagonizada por mujeres, contextualiza a las autoras y las obras que componen el corpus de la tesis. El análisis empieza presentando a las escritoras y sigue mostrando los personajes y las historias que escriben.

El capítulo cuarto, Construcción de nuevos modelos de representación de las mujeres en la novela negra española actual desde una perspectiva de 
género, desarrolla los elementos que nos permiten construir los modelos de mujeres en la nueva novela negra. Para ello, establecemos las variables con las que caracterizamos a estos personajes y la postura que adoptan los personajes en relación a los mismos. La profesionalidad que muestran las protagonistas de las novelas en el sentido que define el término la Real Academia Española (versión en línea), como «característica de la persona que desempeña un trabajo con pericia, aplicación, seriedad, honradez y eficacia, o del trabajo así desempeñado». ¿Cómo están representadas las mujeres en sus puestos de trabajo?, ¿son competentes?, ¿encuentran obstáculos para desempeñar su labor por ser mujeres?, etc.; la masculinización y la feminización de las relaciones. Una vez que las mujeres han ingresado en el ámbito público, ¿qué tipo de comportamientos adoptan? ¿Asimilan los comportamientos masculinos y se masculinizan, dentro de lo que es el esquema de la sociedad patriarcal, o, por el contrario, mantienen en el espacio público las conductas que les han sido asignadas tradicionalmente y las ponen en valor? De este modo, la asimilación de las conductas dominantes y la separación de éstas se convierte en una variable de estudio interesante en esta tesis: la maternidad es una de las funciones esenciales que se les han asignado a las mujeres en las sociedades patriarcales, como única y exclusiva en muchas ocasiones. Y no solamente la reproducción biológica, sino también la reproducción y sostenimiento de las estructuras sociales y el cuidado de la familia. En nuestro caso, las protagonistas representan mujeres que han salido al espacio público, lejos de donde se lleva a cabo esta función, ¿cómo son representadas las protagonistas de Giménez Bartlett y Mercedes Castro?; la sororidad, como concepto feminista, hace referencia al tipo de relaciones que se establecen entre las mujeres cuando se definen como iguales y se organizan en redes (informales o formales) que pueden trabajar por la igualdad, o tener objetivos que afecten a su día a día, como alimentar a un conjunto de personas 3 ; la violencia de género, también, es una realidad que se cuela en la novela negra de Giménez Bartlett y Castro. Nuestra intención es analizar la forma en que se representa tanto si hace referencia a la agresión física o psicológica entre individuos de diferente sexo que mantienen una relación, como si se trata de la violencia sistémica que se manifiesta a través de los denominados

\footnotetext{
${ }^{3}$ Como las «ollas populares» que diferentes grupos de mujeres organizaron en 2001 para responder a la situación de crisis que les impedía cubrir las necesidades alimenticias de sus familias (Gutiérrez, 2013).
} 
micromachismos; por último, hay que señalar que el control sexual es fundamental en las sociedades patriarcales. En la novela negra la situación que ocupan los personajes femeninos está subordinado a las necesidades del protagonista. Alicia Giménez Bartlett y Mercedes Castro subvierten esta situación al convertir en el centro de la historia a una mujer (Petra Delicado, Clara Deza, Teresa Sinde), ¿cómo influye esto en la sexualización de los personajes? El criterio para elegir estos elementos y no otros para caracterizar a los modelos de protagonistas ha sido que estos aspectos influyen día a día en la vida de las mujeres y en la construcción de su identidad frente a la sociedad. Son recurrentes los mensajes desde las instituciones sobre la brecha salarial, la discriminación en el ámbito laboral, la doble jornada, la maternidad, las agresiones sexuales, etc. Por otra parte, son variables que definen la imagen que en los medios (de comunicación y sociales, como las redes) se transmite de «la mujer», centrándose en la proyección de imágenes muy concretas que la inscriben en colectivos más o menos femeninos, más o menos «mujer» según el grado de cumplimiento de las características y valores considerados adecuados por el sistema patriarcal.

El quinto capítulo, Conclusiones y futuras líneas de investigación, desgrana los aspectos más destacados que hemos desarrollado en la tesis para responder al objetivo que planteábamos al principio, caracterizando los modelos de mujeres que aparecen en las novelas de Giménez Bartlett y Castro, y comprobar si se trata de un nuevo modelo de personaje femenino dentro de la novela negra.

Finalmente, cerramos la tesis con un esbozo de líneas de investigación abiertas para continuar trabajando en el futuro, con el fin de profundizar en nuevos aspectos relacionados con la novela negra española, que han surgido a lo largo de la investigación.

Tras estos capítulos, señalamos un apartado de bibliografía, que hemos dividido en dos partes: bibliografía primaria, en la que se señalan las novelas que componen el corpus de esta tesis y las obras literarias que se mencionan en el desarrollo de la misma, y bibliografía secundaria, en la que hacemos constar todas las referencias citadas. 
Además, añadimos un índice de imágenes en el que incluimos la procedencia y autoría de las imágenes que ilustran algunos de los apartados de la tesis.

Con nuestra investigación pretendemos dar valor a estos nuevos personajes y facilitar un análisis y deconstrucción que sirva para que se tomen como referentes para nuevas feminidades, pero también como nuevas formas de relación entre personas que faciliten uno de los objetivos más necesarios del feminismo: crear sociedades igualitarias y, por tanto, justas para todos sus individuos. 



\section{CAPÍTULO 1. \\ EL ORIGEN Y DESARROLLO DE LA NOVELA NEGRA}

1.1. Origen de la novela negra: el relato enigma

1.2. Hard-boiled: la evolución estadounidense del género negro

1.3. Novela negra desde mediados del siglo XX hasta la actualidad

1.4. Aproximación a las novelas negras periféricas. El caso de la novela negra japonesa, la novela negra africana y la novela negra de la India

1.5. Mujeres escritoras. Una forma diferente de entender la literatura

1.6. Síntesis 



\section{CAPÍTULO 1. El origen y desarrollo de la novela negra}

Desde la infancia, no he sido como los demás ni he visto lo que los demás.

Edgar Allan Poe

Se hace necesario comenzar haciendo una precisión terminológica sobre la diversidad y los matices que aparecen al hablar del género: enigma, detectivesco, policiaco, policial, negro...

En España, la discusión en torno a la pertinencia de un término sobre otro comienza en la década de los ochenta del siglo pasado. Salvador Vázquez de Praga (1983), por ejemplo, reflexiona sobre el tema en los siguientes términos:

[...] lo cierto es que los autores españoles que han escrito novela policiaca en sentido amplio, lo han hecho o bien desde el campo de la narración popular, con la simplificación estilística que ello compone, o bien desde el campo de la literatura general, de la llamada literatura «seria», sea como mero entretenimiento de autores más o menos consagrados en otros terrenos, sea en un intento de dignificación de la novela policiaca y consecuencia de ello es que los primeros, los autores de novela popular, han olvidado con frecuencia que estaban escribiendo «novelas», y los segundos, los escritores «serios», han olvidado del mismo modo que se trataba de narraciones «policiacas», y desde luego si no existe una base literaria, la forma, y un contenido policiaco, el fondo, difícilmente puede hablarse de novela policiaca.

Si en lugar de hablar de novela policiaca que, aparte de su significado real o etimológico, es un término que se utiliza vulgarmente para designar la novela enigma, nos referimos a la novela criminal como término más amplio que incluye además la novela negra y la novela de aventuras policiacas (Vázquez de Praga, 1983: 26).

El término «novela criminal», propuesto por Vázquez de Praga, es adoptado por otros autores como José R. Vallés Calatrava (1991), que lo considera menos confuso que el término novela «policiaca», con el que hace referencia a estos 
relatos de los orígenes, aunque en la crítica española el término no es de uso mayoritario.

Más tarde, José Colmeiro (1994) introduce los conceptos: «novela policiaca clásica (novela enigma)» y «novela policiaca negra» dependiendo de las características concretas del relato y el origen del mismo. Este término ha tenido mucho más éxito y se ha consolidado en los ámbitos de la crítica, la investigación y la academia.

Patricia Hart (1987) se decanta por utilizar el término «género negro», para la novela española, ya que, de forma general, son novelas inscritas en el realismo social crítico, y se desarrollan en un espacio urbano con características de la hardboiled estadounidense al estilo de Raymond Chandler (1888-1959) y Dashiell Hammet (1894-1961).

Joan Ramón Resina (1997) presenta una terminología variada y, en ocasiones, confusa, al emplear los conceptos de «novela policiaca» y «novela policial». Parece que el primero hace referencia a la novela clásica (de enigma) y el segundo a un conjunto más amplio.

Así pues, la crítica ha realizado mayoritariamente una división de género entre la novela policiaca, que hace referencia a la novela clásica o de enigma, y la novela negra, que incluye la novela criminal, novela negra o hard-boiled norteamericana. Es decir, el término tiene una fundamentación evolutiva.

En la actualidad, se produce una fragmentación del género en diferentes subtipos dependiendo de la procedencia geográfica y las características del relato o los personajes, que se refugia bajo el término "género negro», convirtiéndose así en un término genérico. Las editoriales emplean en sus catálogos esta denominación, los festivales que se organizan en torno a este tipo de literatura también hacen uso del término «negro» o «negra», por ejemplo, la BCNegra, Castelló Negre, la Semana Negra de Gijón, etc. Incluso las librerías tienen bajo esta denominación la colección de títulos relacionados con este género. Una de las más conocidas, regentada por Paco Camarasa y Montse Clavé, es Negra y Criminal (2002-2015), en Barcelona, nombre que ha tomado un programa dedicado al género negro que se emite actualmente (desde 2016) en Cadena SER. La 
popularización del término es tal que, en ocasiones, solamente la palabra nos remite a este género literario, como señala Malgorzata Janerka (2010) al hablar de la consolidación del término.

Así pues, a lo largo de la tesis emplearemos el término «género negro» de manera genérica, sin que ello excluya la posibilidad de hablar de subtipos de novela negra: novela enigma, detectivesca, etc. cuando hagamos una referencia concreto a un periodo histórico de la evolución del término, si todavía no se había acuñado, en ese momento, este concepto.

La popularidad del género negro en todas sus formas es indiscutible desde sus inicios. El primer crimen, perpetrado por Edgar Allan Poe, marca el comienzo de una tradición literaria que, independiente de su consideración de alta o baja cultura (Colmeiro, 1994; Pizarro Prada, 2013), ha sido ampliamente aceptada por todo tipo de público, incluida la literatura infantil. Es el caso de las aventuras de Gerónimo Stilton (Elisabetta Dami, 1972- ), que se han traducido a cuarenta idiomas en ciento cincuenta países y que han vendido más de cien millones de ejemplares, obviamente adaptadas para niñas y niños de entre 8 y 14 años, omitiendo lo más sangriento y dejando la vertiente de misterio, pero siguiendo una estructura clásica en la que se van eliminando culpables hasta que se descubre al «criminal», secuestrador, ladrón... De esta manera, desde muy jóvenes las lectoras y lectores pueden acostumbrarse a la estructura de este tipo de novelas aprendiendo a decodificar las historias de género negro. Las personas aficionadas al género se convierten en fans que esperan cada entrega con expectación y buscan la última novedad editorial o el título nuevo de sus sagas favoritas, convirtiéndolo en un fenómeno de gran popularidad. Sólo por mencionar algunas de las que han sido grandes éxitos en España en la última década podríamos destacar: la serie de Kurt Wallender (Henning Mankell, 1948-2015), que ha vendido 35 millones de ejemplares y ha sido traducida a 37 idiomas; la saga Millennium (Stieg Larsson, 1954-2004 y David Lagercrantz, 1962- ), con 80 millones de copias en 50 países, o la Trilogía del Baztán, de la española Dolores Redondo (1969- ), que ha vendido más de 700000 copias y se ha traducido a 15 idiomas, y así podemos seguir sumando. 
P.D. James (2009 [2010]) define la novela negra, siguiendo el subtipo novela detectivesca, según su rígida estructura, a pesar de lo cual acepta que cualquier novela podría considerarse detectivesca si se le añade un misterio.

Aunque la narrativa detectivesca también puede, en los momentos culminantes, operar en el límite peligroso de las cosas, se diferencia de la literatura general y del grueso de las novelas de misterio en que presenta una estructura muy definida y se ajusta a unas convenciones establecidas. Lo que podemos esperar es un crimen misterioso, normalmente un asesinato, en torno al cual se centra todo; un círculo cerrado de sospechosos, todos ellos con móvil, medios y oportunidades para haberlo cometido; un detective, aficionado o profesional, que se aparece cual deidad vengadora para resolverlo; y, al final del libro, una solución a la que el lector debería poder llegar por deducción lógica a partir de las pistas introducidas en la novela mediante artificios engañosos pero sin olvidar las normas básicas del juego limpio [...] para que un libro sea descrito como narrativa detectivesca debe haber un misterio central, y un misterio que al final se resuelva de manera lógica y satisfactoria y no por mor de la buena suerte o la intuición, sino mediante un proceso de deducción inteligente a partir de las pistas presentadas con picardía, pero sin engaños (James, 2009 [2010]: 9).

Veamos cómo se inició este género y, brevemente, cómo ha evolucionado hasta la actualidad.

\subsection{Origen de la novela negra: el relato enigma}

La teoría literaria mayoritariamente considera que «Los crímenes de la calle Morgue» (The Murders in the Rue Morgue, 1841) de Edgar Allan Poe (1809-1849) supone el primer relato del género (Vallés Calatrava, 1991, Rodríguez Pequeño, 1995) ${ }^{4}$. A este relato se le sumarán inmediatamente El misterio de Mary Roget (The

\footnotetext{
${ }^{4}$ Aunque Thomas Narcejac (1986) considera que antes de los relatos de Edgar Allan Poe existían precedentes de la novela policiaca en relatos como Edipo, escrito por Sófocles en el 430 a.C., o Hamlet, escrito por William Shakespeare hacia el 1603, entre otros. Sin embargo, en esta investigación nos sumamos a la corriente general que establece el origen del género en 1841 con la publicación de «Los crímenes de la calle Morgue». De todas
} 
Mystery of Mary Rôget, 1842) y La carta robada (The Purloined Letter, 1844), del mismo autor. Las tres historias se desarrollan de la mano de Auguste Dupin, cuyo nombre completo es Chevalier Auguste Dupin, un aristócrata venido a menos que colabora con la policía. No es un detective profesional y usa la razón y el intelecto para resolver los crímenes. Las novelas están escritas por su acompañante en estas aventuras, a quien parece leer la mente. Arthur Conan Doyle se inspirará en él para crear a Sherlock Holmes.

Todas estas historias reflejan la situación social que se está produciendo con las revoluciones burguesas que han desembocado en la revolución industrial que conlleva la economía fabril y de consumo que se produce. Estos relatos, que en un primer momento se publican en fascículos coleccionables, son recopilados por el escritor francés Charles Baudelaire (1821-1867) en un volumen denominado Historias extraordinarias (1855). Este nuevo género literario se abre paso en una sociedad cambiante cuya estructura socioeconómico-política está en crisis reflejando esta realidad de manera «sencilla» y «adaptable» para todo tipo de público.

Así pues, no es de extrañar que sea en países donde esta transformación se está produciendo de manera más rápida y profunda donde aparezca un número mayor de ejemplos del nuevo género. Al escritor estadounidense se le suman autores en otros países, como Arthur Conan Doyle en Inglaterra o Maurice Leblanc en Francia, provocando que al mismo tiempo surja un tipo de literatura separada geográficamente, pero con espacios comunes, modelos de novela policiaca que, sin embargo, se influyen. El contexto de su nacimiento explica el motivo por el que la novela negra, entendida como un género amplio, ha estado íntimamente ligada a un paisaje urbano, rodeado de los ámbitos más pobres y miserables de la sociedad donde la delincuencia se convierte en un modo de supervivencia para una clase trabajadora empobrecida (salarios muy bajos, hacinamiento en las viviendas, falta de planificación familiar, trabajo infantil, insalubridad...).

formas, no negaremos que cualquier género literario presenta características de géneros anteriores, ya que las autoras y autores no son inmunes a los antecedentes y la literatura no se desarrolla en compartimentos estancos. 
En esta edad temprana del género es fundamental entender para la investigadora e investigador entender lo que sucede en el contexto socioeconómico-político.

La aparición de los Estados supone un cambio socioeconómico-político. La organización política del feudo basada en alianzas entre señores dependiendo de la fuerza militar de cada uno para defender sus territorios, deviene, durante la Edad Moderna, en la concentración y centralización del poder de un territorio físico por parte de un único gobernante, el Rey, que pasa de ser el primus inter pares a ser el gobernante absoluto. No nos extenderemos en describir cómo se lleva a cabo este proceso, pero sí señalaremos que el nuevo sistema político crea nuevas necesidades y nuevas estructuras de gobierno. El Estado necesita, para mantener el «orden», el derecho de la fuerza que queda en manos del ejército, ahora bajo las órdenes exclusivas del monarca absoluto. Este ejército presentará mecanismos similares para «mantener la seguridad», sea la «amenaza» interna o externa.

Esta situación cambia con las revoluciones burguesas, especialmente con la Revolución Francesa (1789), cuando no hay que proteger, únicamente, los aspectos físicos, sino también los derechos de los individuos (varones con rentas) ${ }^{5}$ : libertad, vida y, lo más relevante en ese momento, propiedad (Guillem, 2012). En este contexto no sirven las estrategias militares, ya que no es lo mismo defenderse de un enemigo externo que asegurar la seguridad de la ciudadanía. Así se divide la seguridad del Estado entre el ejército, que se encargará de la seguridad exterior, y la policía, que asegurará la seguridad interior, en teoría, porque en la práctica las revueltas que se producen como respuesta a la represión, la injusticia, las hambrunas, etc. provocan el retraso de la desmilitarización completa de la seguridad hasta el siglo XX. En algunos países se opta por una vía intermedia en la que los cuerpos de seguridad usan técnicas policiales pero con disciplina y

\footnotetext{
${ }^{5}$ La «Declaración de Independencia de los Estados Unidos» está fechada en 1776 y la «Declaración de los Derechos del Hombre y del Ciudadano» es de 1789.
} 
estructura militar (Guardia Civil española (1844), Carabinieri italianos (1814), Gendarmerie Nacionale francesa (1719), entre otros) ${ }^{6}$.

La revoluciones burguesas llevan consigo un cambio político, pero también económico y social. A mediados del siglo XVIII se inicia la revolución industrial en occidente (destacan Reino Unido, Francia, Alemania y Estados Unidos). Esto significa que los sistemas de producción, que, hasta ese momento, se habían centrado en la agricultura y el comercio, basculan hacia sectores industriales manufactureros. Este cambio viene de la mano de la mecanización de los procesos de fabricación que antes de la Edad Moderna se centraban en la producción artesanal gremial y a partir de la industrialización pasa a ser mecanizada y concentrada en fábricas. Así pues, la población se traslada del campo a la ciudad, donde se convierte en mano de obra para las industrias. La revolución industrial que lleva aparejada la creación de bienes de consumo no puede triunfar si no se produce el cambio de mentalidad y de actividad económica, transformando la autarquía local en la economía capitalista de producción y comercialización de bienes de consumo. Es decir, hace falta la conversión de trabajadores que satisfacen sus propias necesidades en trabajadores asalariados ${ }^{7}$, lo que produce un «divorcio» entre productores y medios de producción (Hobsbawn, 1971 [2003]). Estos cambios suponen una transformación de los núcleos de población, que pasa de comunidades de tamaño variable a grandes ciudades con una población muy numerosa. En estas urbes, ya no se puede ejercer un «control social» informal y basado en la costumbre como sucedía en la comunidad feudal. Normas que casi siempre estaban basadas en la subsistencia de la comunidad y tenían un sustrato religioso. Normas morales y de conducta que los propios individuos se autoimponían. Si se quebrantaba alguna norma o ley, generalmente, eran los

\footnotetext{
${ }^{6}$ Los cuerpos de policía con estructura militar que se han mantenido hasta la actualidad tienen como característica principal que la dirección se deja en manos de autoridades civiles. Por ejemplo: la Guardia Civil depende de los Ministerios de Interior y Defensa españoles.

${ }^{7}$ En este caso utilizamos el masculino porque la bibliografía consultada siempre hace referencia a trabajadores, pero hay que tener en cuenta que esta mano de obra, este proletariado, que la RAE (versión en línea) define como «En la ideología marxista, clase social formada por los trabajadores que no poseen medios de producción y que obtienen su salario de la venta del propio trabajo», está conformado por hombres, mujeres y niñas y niños (el trabajo infantil es habitual), ya que para subsistir toda la familia debe contribuir con su trabajo.
} 
miembros de la comunidad quienes establecían sanciones. Pero en las ciudades no se pueden usar estos mecanismos de vigilancia y sanción, pues no todo el mundo se conoce, la procedencia es diversa, la religión no tiene una presencia tan clara en la comunidad, etc. Así que se hace necesaria una organización «profesional» que asegure la convivencia (sobre todo, que proteja a la clase burguesa que tiene los medios de producción, la riqueza y, por tanto, la propiedad) ${ }^{8}$. Surgen los «cuerpos policiales» cuyo objetivo sería controlar a los pobres y desarraigados, más que investigar crímenes (Guillén, 2015) 9 .

Isabel Olmos Sánchez (2013: 76) señala que la «miseria, desarraigo y hacinamiento constituyen la primera consecuencia de la revolución industrial». Las ciudades no estaban preparadas para recibir a la población que migraba del campo a la ciudad. La precariedad de las viviendas donde se amontonaban miles de personas, los bajos salarios (por la gran disposición de mano de obra), la desprotección en materia laboral provocaba abusos en las plantillas, la falta de una estructura de atención sanitaria, etc. Eran habituales las revueltas por la carestía de alimentos, los abusos de los patronos, la falta de empleo o la explotación de los que sí tenían trabajo, la falta de seguridad laboral ${ }^{10}$, entre otras cuestiones que con la creación de los sindicatos y la lucha del movimiento obrero desde mediados del siglo XIX se fueron mejorando, aunque habrá que esperar hasta avanzado el siglo XX para situar el momento de mayor cobertura y garantías para los trabajadores y trabajadoras.

\footnotetext{
${ }^{8}$ El artículo 8 de la «Declaración del hombre y del ciudadano» establece que «La seguridad consiste en la protección concedida por la sociedad a cada uno de sus miembros para la conservación de su persona, de sus derechos y de sus propiedades» (Berlière, 2011:50).

${ }^{9}$ Clive Emsley (2011) repasa el origen de los modelos de policía y establece que a pesar de que en algunas investigaciones se habla de dos modelos distintos (uno que estaría representado por la policía de Reino Unido y Estados Unidos y otro que lo formarían las denominadas policías europeas (continentales)), sólo existe un modelo de policía. A pesar de ello, hay que tener en cuenta que el primero surge de un "sistema prepolicial de vigilantes parroquiales y serenos» (Emsley, 2011: 21) mientras que el segundo evoluciona a partir una estructura militarizada, de ahí que todavía hoy día persistan algunos cuerpos de estructura militar (como hemos mencionado con anterioridad).

10 Hoy día existe una legislación importante en materia laboral, que si bien se puede cuestionar para pedir más cobertura, garantiza la seguridad en el puesto de trabajo mediante las medidas de prevención de riesgos laborales. Además, es obligatoria la cobertura sanitaria, el salario mínimo, etc.
} 
En la Europa continental, el sistema policial es un poco diferente al británico. El historiador y criminólogo Clive Emsley afirma que, a pesar de que la policía de la época victoriana ${ }^{11}$ (1837-1901) usó «la violencia, a veces de forma indiscriminada y excesiva, pero por medio de los comentaristas, tanto ingleses como europeos, no fueron vistos tan violentos como los cops estadounidenses, los flics franceses, o los Bulles alemanes» (Emsley, 2011: 47). A pesar de ello, será en Francia donde se intenta crear un «modelo republicano» policial que case con los principios democráticos. Jean-Marc Berlière señala que

[...] la policía judicial, la policía de los crímenes y delitos, auxiliar de la justicia, encargada de la defensa de los ciudadanos, de aportarles seguridad, parecía la indicada para encarnar el modelo del «modelo» y ofrecer un escaparate con todos los atractivos con que más se beneficiaron de la popularidad del «sabueso», confirmada a principio de siglo por el éxito de la novela de detectives (Berlière, 2011: 63).

En un momento de cambio en el que se intenta incluir la ciencia racionalista en todos los ámbitos de la sociedad, entre ellos, la investigación criminal, surgen profesionales como Alphonse Bertillon (1853-1914), que introdujo la antropometría en la investigación policial ${ }^{12}$. La racionalidad científica se filtra

\footnotetext{
${ }^{11}$ La época victoriana hace referencia al periodo del reinado de la reina Victoria I. Se divide en tres periodos: victorianismo temprano, «Early Victorian» (1837-1851), que supone el «asentamiento social surgido de la Revolución Industrial, con importantes conflictos reveladores de fuertes tensiones de clase» (Canales, 1999 [2008]: 7); victorianismo medio, «Mid Victorianism» (1851-1873), es un periodo de estabilidad interna en el que se desarrollan los denominados valores victorianos (básicamente puritanos) y el colonialismo británico «apoyado en la privilegiada posición económica derivada de la temprana realización del proceso industrializador» (Canales, 1999 [2008]: 7); victorianismo tardío, «Late Victorian» (1873-1901), la crisis económica de 1873 provoca un aumento de «las tensiones internas, representadas por la insoluble cuestión irlandesa y el desarrollo de un movimiento obrero y sindical de corte más reivindicativo» (Canales, 1999 [2008]: 7), lo que provoca que países que no sufren de forma tan directa esta crisis económica desafíen el liderazgo en las colonias.

${ }^{12}$ Se inicia un sistema de archivo de fichas donde se describen las características físicas de quienes eran detenidos. El criminólogo Bertillon no cree que el sistema utilizado sea efectivo, por ejemplo, las fotografías de estos archivos eran retratos posados en los que se perdían los detalles para la identificación del individuo. Así que la policía desarrolló un sistema que se basaba en la medición de diferentes partes del cuerpo: «altura, envergadura con los brazos abiertos y contorno de busto con el sujeto sentado; la longitud y anchura de la cabeza, longitud del dedo medio de la mano izquierda, del pie izquierdo y del antebrazo izquierdo» (Montiel Álvarez, 2016: 155). Sin embargo, se observó que podían coincidir las medidas de más de un individuo por lo que no resultaba completamente eficaz para el objetivo que pretendía, identificar de forma inequívoca a los
} 
hasta tal punto en el ámbito judicial y policial que, en Francia, surge la incipiente ciencia forense para investigar crímenes, que se ve reflejada de algún modo en estos relatos. La policía técnica y científica que se crea pretende ser una policía infalible que dejará atrás las técnicas de interrogatorio que trataban de conseguir confesiones (Berlière, 2011). Aspecto que utilizan las escritoras y escritores de novela negra en sus historias. El positivismo científico que se desarrolla durante el siglo XIX lleva a la creencia de que se puede racionalizar la conducta delictiva desplegando ideas como que las y los criminales (tanto mujeres como hombres) cuentan con unas características físicas determinadas, como escasa capacidad craneal, senos frontales muy desarrollados, mayor espesor de los huesos del cráneo, mandíbulas muy desarrolladas, piel muy pigmentadas, pelo rizado y espeso, orejas grandes, entre otros. Además, en lo referente a los rasgos morales y comportamentales, se consideran aspectos como adelanto en el inicio de las prácticas sexuales, pereza, impulsividad, predisposición al alcoholismo y las supersticiones (religiosidad), como señala Teresa Montiel Álvarez (2016). En este ambiente evoluciona el género hasta la estructura que conocemos actualmente. Es un momento de cambio, se intenta incluir la ciencia racionalista en todos los ámbitos de la sociedad, entre ellos, la investigación criminal, como hemos señalado, y de ahí que se introduzca la ciencia forense para investigar los crímenes, que se ve reflejada de algún modo en estos relatos, bien en la descripción de los personajes, bien introduciendo la técnica forense en las tramas. Así la investigadora o investigador incluye entre sus observaciones apreciaciones sobre las heridas de los cuerpos o algún rastro encontrado en la escena del crimen. Uno de los primeros forenses investigadores del género es el doctor Thorndyke (Austin Freeman, 1862-1943). En cierto modo, algunas autoras y autores hablan de una sinergia $^{13}$ entre el emergente cuerpo de policía y las técnicas sobre el terreno y las

criminales. Mejor sistema será la identificación de las huellas dactilares que desarrolló el antropólogo Francis Galton (1822-1911), y que extendió el también antropólogo argentino de origen croata Iván Vučetić. Unas técnicas de identificación que han llegado hasta nuestros días. La denominada ficha policial presenta una fotografía de frente y perfil, las huellas dactilares y las marcas distintivas de la persona fichada, como pueden ser tatuajes. ${ }^{13}$ Un ejemplo fue Eugène-François Vidocq (1775-1857), director de la Sûreté Nationale francesa, que introduce elementos científicos en la investigación policial como la recogida de huellas en el lugar del crimen, entre otros. Sus métodos levantaron cierta polémica y fue despedido con la excusa de que la policía no podía ser delincuente. Funda la primera agencia de detectives de la que tenemos noticia, en la que nuevamente contrata a 
investigaciones en la ficción, influyendo en «la concepción de la investigación y la consiguiente creación de laboratorios dedicados al análisis de las pruebas recogidas en el terreno» (López Martínez, 2006: 13).

El índice de analfabetismo, en toda Europa, en el siglo XIX, cabe destacar que era muy elevado, y los folletines y las novelas por entregas ${ }^{14}$, que en muchos casos se leían en voz alta, se hicieron tremendamente populares. La temática era variada y podemos encontrar desde relatos de corte romántico, del oeste, de terror, etc. Algunos de los escritores más reconocidos de la literatura universal utilizaron este formato para publicar algunos de sus relatos, como Leon Tolstoi (1828-1910), Benito Pérez Galdós (1843-1920) o Charles Dickens (1812-1870), quien junto a Williams Wilkie Collins (1824-1889) resulta fundamental en el desarrollo del género negro.

Dickens $^{15}$ se introduce en el género policiaco con The Detective Police (1851) para la revista Household Words, un compendio de relatos publicado a mediados del XIX. En estos relatos aparecen los Bow Street Runners, que son los primeros agentes de policía que hay en Londres. Pero lo más destacado no es tanto que aparezcan estos policías que son el germen de la policía londinense, sino que

delincuentes como él. Su aportación consiste en adaptar los métodos científicos a la investigación policial. Inspiró a personajes de Edgar Allan Poe. Su reconocimiento, hoy día, llevó a una serie de investigadores profesionales y aficionados a crear la exclusiva Vidocq Society (Filadelfia, 1990) en la que únicamente se aceptan 82 miembros y para acceder hay que demostrar una importante experiencia forense e investigadora (González de la Aleja Barberán, 2014: 180).

${ }^{14}$ Los términos folletines y novela por entregas, aunque en ocasiones se confundan, como señala Ma Pilar Aparici Llanas y Gimeno (1996), hacen referencia a dos tipos de literatura que se publicaba de forma seriada (mediante fascículos). En el caso del folletín se trataba de una sección del periódico. Generalmente ubicado en la parte inferior de éste, y que podían ser novelas publicadas que se fragmentaban. La novela por entregas era un encargo expreso de un editor que tenía una longitud variable y debía ajustarse a unos plazos de entrega, una extensión reducida por capítulo y el hecho de que debía cerrarse en un punto interesante de la narración, ya que había que crear ese interés. A este tipo de publicaciones, se accedía por suscripción (la periodicidad era semanal). Era habitual que estuvieran encuadernados e incluso hubiera ilustraciones. La duración era variable y dependía del éxito del relato.

${ }^{15}$ El escritor británico había explorado lo criminal con anterioridad en alguno de sus relatos, como Oliver Twist (1837-1839), donde el protagonista, para escapar de la miseria se une a la banda de unos carteristas dirigidos por el malvado Fagin, pero la crítica tradicional considera a esta novela como novela social. 
utiliza por primera vez la palabra detective. La siguiente incursión en la novela negra será Casa desolada (Bleak House, 1852-1853) publicada por entregas, en la que aparece el inspector Bucket, considerado por la crítica como el primer detective profesional del género negro, sin dejar de lado la mirada social que el escritor británico presenta en sus obras ${ }^{16}$. Dickens «buscaba mejorar la imagen de la policía, hasta entonces bastante desprestigiada en la mayor parte de la narrativa relacionada con el crimen». Como hemos visto la aportación que hacen estos autores contribuyó a la progresiva sustitución del «criminal en el papel de héroe, preparando el camino a la llegada del "Gran Detective” (González López, 2004: 57). Este cambio en la representación de la policía en la ficción corre aparejado a mejoras en el sistema policial, judicial y carcelario, ya que «sin la aparición de un sistema estable de policía, difícilmente podría haber surgido la novela de detectives» (González López, 2004: 57; Collins, 1962).

Dickens compagina la escritura de historias de detectives con otros géneros. A su muerte será su amigo Wilkie Collins ${ }^{17}$ el que tome el testigo para desarrollar la novela negra.

El interés de las clases trabajadoras por lo truculento y criminal al final de la época victoriana (caracterizada por la austeridad y rigidez moral) era enorme y este tipo de relatos seriales que giraban en torno a un crimen eran muy populares. Por ejemplo, en Gran Bretaña surgieron los Penny Dreadful, publicaciones periódicas de baja calidad, de corte sensacionalista y temática criminal o

16 Oliver Twist (Oliver Twist o The Parish Boy's Progress, 1837-1839); Cuento de Navidad (A Christmas Carol, 1843); David Copperfield (David Copperfield, 1949-1950); Tiempos difíciles (Hard Times for These Times, 1854); La pequeña Dorrit (Little Dorrit, 1955-1857); Historia de dos ciudades (Tales of Two Cities, 1859); Grandes esperanzas (Great Expectations, 18601861) son algunas de las novelas del autor británico. En ellas dibuja la miseria de los barrios proletarios, la explotación infantil, las enfermedades, la falta de alimentos, etc. y lo enfrenta con los excesos de las clases altas, estos temas también aparecen en Bleak House. 17 Collins, como otros autores de su época, trató en algunas de sus novelas los problemas sociales de la sociedad británica, incluyendo en alguna de sus historias la situación en la que vivían las mujeres como en La dama de blanco (The Woman in White, 1860). Este relato se encuentra entre el relato de misterio y una incipiente novela policiaca. Pero no será al único grupo minorizado que preste atención, en Hide and Seek (1854) el protagonista es sordo. Isabel Sataulàlia i Capdevila (2005b), en su repaso a la novela negra de Gran Bretaña, señala que el autor en Una cama terriblemente extraña (A Terrible Strange, 1852) presenta el primer detective profesional. También La piedra lunar (The Moonstone, 1868) incluía este tipo de personaje, como secundario, que en este primer momento no es muy apreciado por la clase burguesa. 
romántica, que provocan «adicción» entre la población menos privilegiada, «clases media-baja analfabetas y con suficiente tiempo libre y poder adquisitivo para acceder a la lectura» (González López, 2004: 57), aunque esta nueva literatura tampoco deja indiferente a las clases burguesas. Éste es el caldo de cultivo para el éxito de la novela policiaca que acaba de nacer, este interés por lo criminal junto con una incipiente lucha de clases por las condiciones de trabajo en las fábricas y la pérdida de identidad como trabajadores en las ciudades. El escritor es consciente de que está escribiendo para un público lector que va a interactuar con la historia, que puede comentar con otros lectores (y lectoras), al tratarse de un relato fragmentado, el público puede teorizar sobre quién ha hecho qué. Así, el escritor debe dar «pistas» parciales o completas, falsas o verdaderas, para establecer ese juego que provoca el deseo de comprar la siguiente entrega (López Martínez, 2006; James 2009 [2010]).

La primera forma que adopta la novela negra podemos catalogarla con el subtipo de relato enigma (Resina, 1997; Rodríguez Pequeño, 1995) y es la que conocemos todas y todos a través de personajes tan emblemáticos como Sherlock Holmes ${ }^{18-19}$ (Arthur Conan Doyle, 1859-1930), un investigador aficionado, adicto a

\footnotetext{
${ }^{18}$ Un personaje que ha llegado a nuestros días en espléndida forma, como demuestra el hecho de que se revisite constantemente, no sólo en el ámbito literario sino audiovisual. El personaje de Holmes se reinventa en versiones actuales de las novelas clásicas, como en la serie Sherlock (BBC, 2010- ). En esta serie se adaptan los casos originales de Doyle a un paisaje contemporáneo: Estudios en rosa (Study in Pink, 2010), el primer capítulo que sigue los pasos de Estudio en escarlata (A Study in Scarlet 1881); El sabueso de los Baskerville (The Hound of Baskerville, 1901-1902), el segundo capítulo de la segunda temporada. Sin olvidar que el resto de capítulos se salpican de elementos que nos retrotraen a los relatos originales. En otras ocasiones, se acomodan a nuevas realidades como en el caso de Elementary (CBS, 2012- ). En esta ocasión, además de trasladar la acción a un escenario diferente, el Nueva York de principios del siglo XXI, optan por cambiarle el sexo a Watson, que se transforma en Joan Watson. El último ejemplo, que mencionaremos, lo representaría la serie House M.D. (Fox, 2004-2012), que transforma al detective en médico y las pistas son síntomas de una enfermedad. Sea como fuere, lo que no varía son las características del personaje protagonista: perspicaz y con grandes dotes de investigación. Tampoco varía que tiene a su lado a un compañero o compañera que atempera su carácter volátil y obsesivo, en ocasiones. Sin olvidar que la estructura narrativa se mantiene adaptada a las herramientas de la realidad audiovisual. El cine también se ha acercado al detective de Arthur Conan Doyle en numerosas ocasiones. Las dos últimas versiones: Sherlock Holmes (Guy Ritchie, 2009), Sherlock Holmes: juegos de sombra (Sherlock Holmes: A Games of Shadows, Guy Ritchie, 2011) basada en Memorias de Sherlock Holmes (The Memoirs of Sherlock Holmes, 1893), una colección de relatos del detective. En esta ocasión,
} 
la cocaína, y con una capacidad de observación fuera de lo normal. Otros autores que también destacan en este momento, pero en el ámbito de la literatura de género policiaco francés, son Émile Gaboriou (1832-1873), G. K. Chesterton (18741936) y Gastón Leroux (1898-1927)20. Gaboirou crea a Lecoq, un detective profesional que trabaja para la policía francesa. Es capaz de disfrazarse para confundirse con el paisaje urbano y de delincuencia en el que trabaja. Es un hábil policía y buen observador. El personaje está inspirado en el policía EugèneFrançois Vidocq, como hemos comentado antes.

Chesterton ${ }^{21}$ es conocido por crear al padre Brown ${ }^{22}$, un sacerdote católico que, a pesar de su devoción sabe encontrar la solución más racional y mundana a los misterios más extraños.

A sentar las bases del género, en sus inicios, también contribuye Gastón Leroux. En este caso, utiliza a un periodista que hace de detective aficionado, Joseph Rouletabille, algunos de sus títulos destacados son: El misterio del Cuarto Amarillo (Le mystère de la chambre jaune, 1907), El perfume de la Dama de Negro

el director respeta la acotación temporal, recreando un Londres del XIX de cartón piedra donde el detective suma a su típica sagacidad una gran dosis de violencia física.

${ }^{19}$ La serie de Sherlock Holmes: Estudio en escarlata (A Study in Scarlet, novela, 1887), El signo de los cuatro (The Sign of Four, novela, 1890), Las aventuras de Sherlock Holmes (The Adventures of Sherlock Holmes, 1891-92), Las memorias de Sherlock Holmes (The Memoirs of Sherlock Holmes, 1892-93), El sabueso de los Baskerville (The Hound of the Baskervilles, novela, 1901-02), El regreso de Sherlock Holmes (The Return of Sherlock Holmes, 1903-04), Su última reverencia (His Last Bow, 1908-17), El valle del terror (The Valley of Fear, novela, 1914-15), El archivo de Sherlock Holmes (The Case-Book of Sherlock Holmes, 1924-26). También escribió una serie de aventuras centrada en el profesor Challenger y algunos títulos de novela histórica.

${ }^{20}$ Además cultivó el género de terror con títulos como: La doble vida de Théophraste Longuet (La double vie de Theophraste Longuet, 1904) y La reina de Sabbat (La reine du Sabbat, 1910).

${ }^{21}$ Chesterton se sumerge en diferentes géneros literarios, incluso la poesía y el ensayo. Algunos de los título de la serie de padre Brown son: La inocencia del padre Brown (The Innocence of Father Brown, 1911), La sabiduría del padre Brown (The Wisdom of Father Brown, 1914), La incredulidad del padre Brown (The Incredulity of Father Brown, 1926), El secreto del padre Brown (The Secret of Father Brown, 1927), El escándalo del Padre Brown (The Scandal of of Father Brown, 1935).

${ }^{22}$ El padre Brown no es el único miembro del clero que resuelve misterios. Ralph Matthew McInerny (1929-2010) crea al también católico padre Dowling y The Mysteries of Father Dowling- Con el seudónimo de Monica Quill también publica una saga sobre la hermana Mary Teresa (1981-2001). Más recientemente, James Runcie (1959- ) usará a un pastor anglicano, en su serie Grantchester (2012- ). Todos estos personajes han sido llevados a la pequeña pantalla con adaptaciones de sus títulos y sus historias siguen el esquema narrativo tradicional del género. 
(Le parfum de la dame en noir, 1908), Rouletabille en Rusia (Rouletabille chez le tsar, 1912), El Castillo Negro (Rouletabille à la guerre: Le château noir, 1916) y Las Extrañas Bodas (Rouletabille à la guerre: Les étranges noces de Rouletabille, 1916), entre otras. Leroux introduce en la investigación elementos de las novelas de aventuras, y veremos que, en ocasiones, la persecución es tan importante como el seguimiento de las pistas. El escritor publica sus novelas por entregas en el suplemento literario de L'Illustration.

Los elementos caracterizadores de estas novelas, a grandes rasgos, y observando matices propios del género en los ámbitos anglosajón y francés, son:

- El detective es un aficionado que no pertenece a la policía, en la mayoría de los casos. Es poseedor de cualidades extraordinarias que le permiten descubrir, mediante la deducción y la observación, aspectos que a otros les pasan inadvertidos. Excéntrico y narcisista, se comporta de manera displicente con los policías y sus métodos, a los que considera inútiles.

- Suele tener un compañero que hace la función de narrador. Tiene la tarea de apoyar al protagonista, lo que ayuda a subrayar la superioridad del detective tanto sobre él como sobre la lectora o lector, que no tienen sus dotes deductivas tan agudizadas.

- En el proceso de investigación, la autora o autor desarrolla diferentes personajes que aparecen como sospechosos del crimen a la vista de las declaraciones de los testigos. Así, al mismo tiempo que el detective, la lectora y lector van acumulando pistas.

- La racionalidad es la forma de resolver el crimen, ya que el crimen se plantea como un enigma-misterio. La técnica de investigación se encaja en la narración.

- Todos estos personajes ponderan la razón sobre la acción.

En la misma línea desarrolló su actividad Agatha Christie ${ }^{23}$ (1890-1976), en el periodo de entreguerras, convirtiéndose en una de las damas de la novela

\footnotetext{
${ }^{23}$ Agatha Christie escribió numerosas novelas: The Mysterious Affair at Styles (El misterioso caso de Styles, 1920); The Secret Adversary (El misterioso señor Brown, 1922); The Murder on the Links (Asesinato en el campo de golf, 1923); The Man in the Brown Suit (El hombre del traje marrón, 1924); The Secret of Chimneys (El secreto de Chimneys, 1925); The Murder of Roger Ackroyd (El asesinato de Roger Ackroyd, 1926); The Big Four (Los cuatro grandes,
} 
policiaca. Crea a Hercules Poirot y Miss Marple. Sus personajes suelen presentarse

1927); The Mystery of the Blue Train (El misterio del tren azul, 1928); The Seven Dials Mystery (El misterio de las siete esferas, 1929); The Murder at the Vicarage (Muerte en la vicaría, 1930); The Sittaford Mystery (El misterio de Sittaford, 1931); Peril at End House (Peligro inminente, 1932); Lord Edgware Dies (La muerte de Lord Edgware, 1933); Murder on the Orient Express (Asesinato en el Orient Express, 1934); Why Didn't They Ask Evans? o The Boomerang Clue (La trayectoria del bumerán, 1934); Three Act Tragedy (Tragedia en tres actos, 1935); Death in the Clouds (Muerte en las nubes, 1935); The A.B.C. Murders (El misterio de la guía de ferrocarriles, 1936); Murder in Mesopotamia (Asesinato en Mesopotamia, 1936); Cards on the Table (Cartas sobre la mesa, 1936); Dumb Witness o Poirot Loses a Client (El testigo mudo, 1937); Death on the Nile (Muerte en el Nilo, 1937); Appointment with Death (Cita con la muerte, 1938); Hercule Poirot's Christmas (Navidades trágicas, 1939); Murder is Easy (Matar es fácil, 1939); Ten Little Niggers/And Then There Were None (Diez negritos, 1939); Sad Cypress (Un triste ciprés, 1940); One, Two, Buckle My Shoe (La muerte visita al dentista, 1940); Evil Under the Sun (Maldad bajo el sol, 1941); N or M? (El misterio de Sans Souci, 1941); The Body in the Library (Un cadáver en la biblioteca, 1942); Five Little Pigs (Cinco cerditos, 1942); The Moving Fingerk (El caso de los anónimos, 1943); Towards Zero (Hacia cero u Hora cero, 1944); Death Comes as the End (La venganza Nofret, 1945); Sparkling Cyanide (Cianuro espumoso, 1945); The Hollow (Sangre en la piscina, 1946); Taken at the Flood (Pleamares de la vida, 1948); Crooked House (La casa torcida, 1949); A Murder is Announced (Se anuncia un asesinato, 1950); They Came to Baghdad (Intriga en Bagdad, 1951); Mrs McGinty's Dead (La señora McGinty ha muerto, 1952); They Do It with Mirrors (El truco de los espejos, 1952); A Pocket Full of Rye (Un puñado de centeno, 1953); After the Funeral (Después del funeral, 1953); Destination Unknown (Destino desconocido, 1955); Hickory Dickory Dock (Asesinato en la calle Hickory, 1955); Dead Man's Folly (El templete de Nasse-House, 1956); 4.50 from Paddington (El tren de las 4:50, 1957); Ordeal by Innocence (Inocencia trágica, 1958); Cat Among the Pigeons (Un gato en el palomar, 1959); The Pale Horse (El misterio de Pale Horse, 1961); The Mirror Crack'd from Side to Side (El espejo se rajó de lado a lado, 1962); The Clocks (Los relojes, 1963); A Caribbean Mystery (Misterio en el Caribe, 1964); At Bertram's Hotel (En el hotel Bertram, 1965); Third Girl (La tercera muchacha, 1966); Endless Night (Noche eterna, 1967); By the Pricking of My Thumbs (El cuadro, 1968); Halloween Party (Las manzanas, 1969); Passenger to Frankfurt (Pasajero a Frankfurt, 1970); Nemesis (Némesis, 1971); Elephants Can Remember (Los elefantes pueden recordar, 1972); Postern of Fate (La puerta del destino, 1973); Curtain (Telón, 1975); Sleeping Murder (Un crimen dormido, 1976). También escribió una serie de cuentos: Poirot Investigates (Poirot investiga, 1924); Partners in Crime (Matrimonio de sabuesos, 1929); The Mysterious Mr. Quin (El enigmático señor Quin, 1931); The Thirteen Problems (Miss Marple y trece problemas, 1932); The Hound of Death (1933, inédito en español); Parker Pyne investigates (Parker Pyne investiga, 1934); The Listerdale Mystery (El misterio de Listerdale, 1934); Murder in the Mews (Asesinato en Bardsley Mews, 1937); The Regatta Mystery and Other Stories (Problema en Pollensa, 1939); The Labours of Hercules (Los trabajos de Hércules, 1947); Witness For The Prosecution and Other Stories (Testigo de cargo, 1948); Three Blind Mice and Other Stories (Tres ratones ciegos y otras historias, 1950); The Under Dog and Other Stories (Ocho casos de Poirot, 1951); The Adventure of the Christmas Pudding (Pudding de Navidad, 1960); Double Sin and Other Stories (1961, inédito en español); The Veiled Lady/The Hound of Death/Double Sin (Poirot infringe la ley, 1966); The Golden Ball and Other Stories (1971, inédito en español); Poirot's Early Cases (Primeros casos de Poirot, 1974); Miss Marple's Final Cases and Two Other Stories (1979, inédito en español); Problem at Pollensa Bay and Other Stories (1991, inédito en español); While the Light Lasts and Other Stories (Un dios solitario y otros relatos, 1997); The Harlequin Tea Set and Other Stories (1997, inédito en español). 
como hiperestereotipados, ciñéndose a unas funciones, roles y clases sociales tremendamente estrictos: «Agatha Christie impone un universo autoreferencial regido por un conjunto de relaciones internas donde cada personaje se comporta en función de su rango social, salvo el criminal, el elemento perturbador disimulado, lo cual implica unos criterios para descubrirlo reductores» (Martínez López, 2016: 19). Siguiendo los principios científicos que hemos comentado antes, sus tramas presentan una línea, por la cual la o el culpable permanece oculto a la lectora o lector. A pesar de las características tradicionales de los relatos tradicionales de Christie, comenzamos a ver elementos psicológicos en los culpables, quizás por su condición de mujer (recordemos que la educación no era igualitaria y los currículums femenino y masculino se ajustaban a los roles asignados).

Otra autora que sigue esta línea de narración es Dorothy L. Sayer (18931957) que crea en el periodo de entreguerras la serie de Lord Peter Wimsey (1923-1939). Un dandi aristócrata que resuelve crímenes como afición y que tiene por compañero a su mayordomo (Bunter). A esta serie hay que añadir, posteriormente, algunos relatos más de temática negra.

Las novelas de estas autoras son, en cierto modo, inocentes, a pesar de la violencia de todo crimen. En opinión de James:

Estas novelas son, sin duda, paradójicas. Tratan la muerte violenta y emociones violentas, pero son novelas para evadirse. No se nos pide que sintamos compasión real por la víctima, ni empatía hacia el asesino, ni comprensión hacia el injustamente acusado. Doblen por quien doblen las campanas, sabemos que no es por nosotros. Sean cuales sean nuestros horrores ocultos, no es nuestro cuerpo el que yace en el suelo de la biblioteca. Y al final, por la gracia de las células grises de Poirot, todo saldrá bien, salvo para el asesino, claro está, pero él se merece todo cuanto le ocurra. Todos los misterios se explicarán, todos los problemas se resolverán y la paz y el orden se restablecerán en esa mítica aldea que, a pesar del elevado índice de homicidios, nunca pierde la tranquilidad y la inocencia (James, 2009 [2010]: 40). 
Diana Cerqueiro (2010: en línea) enumera diferentes formas que adopta la novela enigma hasta que el público considera agotada esta fórmula y busca nuevas formas de novela de investigación:

- La historia invertida: comienza con el crimen, la lectora o lector conoce el asesinato desde el principio y el interés reside en ver si el asesino se sale con la suya.

- La historia plana o de vuelta al escenario: en este caso interesa el marco ambiental tanto como el relato de la investigación.

- El howdunit o «cómo lo hizo»: para atrapar al asesino, que es conocido, se tiene que tramar un método ingenioso para que se descubra y el detective pueda probar su culpabilidad.

- El whydunit o «por qué lo hizo»: en este caso se profundiza más en aspectos psicológicos. El culpable parece carecer de los medios para cometer el crimen. Sin embargo, se desvela su capacidad psicológica para hacer cualquier cosa.

- La novela detectivesca: gana peso el comportamiento de las personas que se convierten cada vez en más reales.

- La novela criminal: se centra en los personajes y su entorno. El crimen es fundamental. Sin embargo, estas novelas son como un rompecabezas que otorga mayor énfasis a los personajes, y se presenta como un rompecabezas cuyo objetivo sigue siendo entretener a (jugar con) la lectora o lector.

Vallés Calatrava (1990) señala como central en este subtipo el misterioenigma que se plantea al inicio del relato y que deberá ser resuelto por la investigadora o investigador protagonista. Se establece un juego con la lectora y lector, la intriga, que se alarga desde el planteamiento del caso hasta su resolución, retrasando la solución final.

Este tipo de novela se alarga un poco más en el tiempo, en Inglaterra, porque:

Es precisamente esa visión de Inglaterra [aldeas con gente feliz por el lugar que ocupan en el mundo] la que estaban retratando, por lo general, los escritores de narrativa detectivesca de los años treinta y, en particular, las 
escritoras: clase media, jerárquica, rural y apacible. Pero era una época de ansiedad latente. Antes de la sociedad del bienestar, el miedo al desempleo, la enfermedad y el declive económico era muy real y el creciente poder de los dictadores fascistas en el extranjero presagiaba la posibilidad de otra guerra antes de que el país se hubiese recuperado de la horrible matanza, el levantamiento social y las tragedias personales de la Gran Guerra. Ya la propia posición del fascismo interno estaba provocando enfrentamientos violentos, sobre todo en el East End de Londres. No era de extrañar que la población deseara ese «ambiente de permanente seguridad» y pudieran encontrarlo, al menos de forma temporal, en una fórmula popular que era ordenada y reconfortante (James, 2009 [2010]: 43).

Las autoras y autores que hemos mencionado en este apartado no son los únicos que desarrollan el relato enigma, pero sí a quienes hemos considerado como precursoras y precursores de características que quedarán en el género y que con la incorporación de otros elementos que actualizarán la novela negra perdurarán en el tiempo.

Sin embargo, un nuevo subgénero, procedente de Estados Unidos, acabará por imponerse: el hard-boiled.

\subsection{Hard-boiled: la evolución estadounidense del género negro}

Durante el segundo cuarto del siglo XX, la estructura del género evoluciona. Pasa de una historia basada en la descripción de los acontecimientos, la resolución del enigma, del juego con la lectora y lector y la figura central del detective y el criminal a ser un relato plagado de violencia. El detective aficionado deja paso a un detective profesional, el detective privado, que

[...] recompone el desorden que el crimen ha desencadenado. Su objetivo es el retorno de ese orden, del orden mental por medio de la verdad, y el orden social por medio de la justicia, aunque sepa que no pueda cambiar la realidad en la que se encuentra inmerso, codificada en leyes, y la idea de justicia, que atiende a una noción ideológico-moral, por lo que en algunos casos entregará al culpable a la justicia, en otros se tomará la justicia por su mano sabiendo 
que las leyes protegerán al culpable y éste saldrá impune, y en alguna ocasión, aunque muy escasa, se negará a investigar el caso, por lo que tendremos un relato de aventuras policiales y no una narración policiaca (Martín Cerezo, 2006: 58-59).

Surge la novela negra hard-boiled. Este subgénero se desarrolla sobre todo en Estados Unidos, nuevamente, como consecuencia de una situación socioeconómica de crisis que culminará en la crisis del 2924. Otros aspectos que también se señalan como elementos causales son la Ley Seca ${ }^{25}$ (1920-1933), la corrupción política y, otra vez, un aumento de la delincuencia como consecuencia de todo lo anterior. Así aparece esta novela caracterizada por su realismo y compromiso social (novela de denuncia) ${ }^{26}$ (López Martínez, 2006; Martín Cerezo, 2006).

A las causas socioeconómicas, podemos añadir elementos culturales propios de la sociedad estadounidense y su particular desarrollo literario. De este modo, podemos afirmar que el origen y la evolución de la novela negra en Estados Unidos presenta algunos matices. González López (2004) expone que la novela negra está estrechamente relacionada «con la novela de aventuras, con la características del héroe del western y, en general, con una tradición americana bastante diferente a la tradición clásica de detectives» (González López, 2004: 63).

Retomando la idea de González López (2004) sobre el elemento diferenciador de la novela negra estadounidense, señalaremos que «la obra de Hammett representa en cierto modo la fusión de dos tipos de narrativa popular

\footnotetext{
${ }^{24}$ El crack del 29 hace referencia a la quiebra de la bolsa en octubre de 1929 y que da inicio a la Gran Depresión, un periodo de más de una década en la que Estados Unidos sufre una profunda recesión económica con los problemas sociales que provoca este tipo de crisis (desempleo, pobreza, etc.) (Rémond, 2002).

${ }^{25}$ Se denomina así a la ley que prohibía la fabricación, distribución y venta de alcohol. Esta norma impulsada por grupos religiosos puritanos pretendía la mejor de la moral de la sociedad. Consideraban el consumo de alcohol como responsable de la violencia tanto dentro como fuera del hogar y elemento causal del retraso de la clase obrera. La prohibición provoca el tráfico de alcohol que está rodeado de violencia y delincuencia. Este ambiente del hampa es recreado tanto en literatura como en el cine mediante la figura del gánsteres (Rémond, 2002).

${ }^{26}$ En esta ocasión también hay una doble discrepancia sobre cómo surge el subgénero. Thomas Narcejac (1986) plantea que se trata de una prolongación de la novela inglesa de terror del XIX, una extensión de la novela de gánsteres y una derivación de las novelas popular y policíaca.
} 
norteamericana del siglo XIX, la novela de detectives creada por Poe y el western derivado de las novelas de James Fenimore Cooper» (Margolies en González López, 2004: 63). Los elementos que relacionan el western y la novela negra son, para Cynthia S. Hamilton (1987): localización, héroe, argumento, estilo y tema. Ya que para Hamilton la «fórmula» por la que se rigen estos géneros literarios no son sino un conjunto de elementos interrelacionados de manera convencional que conocen tanto la lectora y lector como la escritora y escritor. Y continúa indicando la posición que la novela negra tendría en la tradición estadounidense.

A group of literary works which all adhere to the same formula belong to the same genre. Thus we can speak of the Western and hard-boiled detective novels as 'subgenre', for both can be subsumed under the American adventure formula, or 'master formula'. From this it follows that a number of 'levels of generalization' are possible: the individual author's interpretation of formula, the subgenre, the master formula, and the archetypal story pattern (Hamilton, 1987: 2).

No extraña que en un país que surge de la «conquista de la frontera» ${ }^{27}$, con todo lo que supone de conflictos y violencia entre los nuevos colonos y la población existente en esos territorios («indios», «salvajes») ante las diferencias de modo de vida, creencias, cultura, etc., aparezca una literatura popular en la que los nuevos habitantes se describan de forma heroica, incluso que se represente esta conquista como una aventura romántica. Uno de los máximos responsables del desarrollo de este género autóctono estadounidense es James Fenimore Cooper (1789-1851) ${ }^{28}$, quien en sus novelas

\footnotetext{
${ }^{27}$ A finales del XVIII, los estadounidenses comenzaron a desplazar la frontera vertical que iba desde New Hampshire hasta Georgia hacia el oeste en busca de tierras más fértiles y huyendo de la presión demográfica que estaban sufriendo. La mayoría de estos pioneros (y pioneras) vivían al «límite de la civilización» y «llevaban a aventura en su sangre», algunos hicieron el viaje de costa a costa buscando una vida mejor. Gregorio Doval (2009) describe a estos conquistadores en los siguientes términos: «Dejando a un lado a aventureros y cazadores, los primeros colonos fueron familias que llegaron por tierra en carromatos, caballo o incluso caminando. Quizás fueron los más valerosos de todos, porque su meta no se centraba en el límite de la frontera civilizada conocida sino en los extremos más lejanos del subcontinente» (Doval, 2009: 18). Estos individuos y sus historias resultaban muy atractivos, especialmente a una población que estaba creando una idiosincrasia sobre los orígenes de una identidad común que les uniera.

${ }^{28}$ Los pioneros (The Deerslayer, 1823); El último mohicano (The Last of the Mohicans, 1826), su obra más representativa; La pradera (The Pathfinder, 1827), El trapero (The
} 
[...] representa los problemas entre los indios y los blancos como metáforas de diversos conflictos de la sociedad americana, explorando las contradicciones entre aristocracia y democracia, naturaleza y civilización, Europa y América, y desarrollando al mismo tiempo la figura de Natty Bumpo ${ }^{29}$, que de hecho se va a construir en arquetipo del héroe literario americano (González López, 2004: 63).

Estas historias del oeste se difunden mediante las dime novels (novelas de diez centavos), novelas populares que se introducen en el mercado para consumo de las clases medias estadounidenses que habían crecido enormemente, sin olvidar que se habían reducido los datos de analfabetismo en estas capas sociales. Rápidamente,

Las dime novels de detectives fueron, pues, una transformación de la fórmula del western, dentro del mismo canal de publicación, y nacieron bajo la influencia no de la novela clásica de detectives, sino de las novelas de Pinkerton, y, en todo caso, del modelo francés de Vicdoq y Gaboriau, en el que predominaba más la acción que el detective racional (González López, 2004: 68).

En estas historias lo de menos era la resolución, lo que interesaba al público era la persecución, la aventura. El primero de los detectives de estas novelas fue Old Sleuth (1872), inspirado en Allan Pinkerton ${ }^{30}$. Las dime novels son el antecedente de la hard-boiled. González López señala:

Pioneers, 1840) y El cazador de ciervos (The Prairie, 1841), pentalogía que se recoge bajo el nombre Leatherstocking Tales.

${ }^{29}$ Nathaniel «Natty» Bumpo es el protagonista de la pentalogía Leatherstocking Tales. Natty es un niño blanco que creció entre los indios de Delaware y fue educado por los moravo cristianos. Capaz e inteligente, es un experto guerrero de gran pericia con las armas, especialmente con el rifle. Suele representarse junto a su hermano de leche, Chingachgook, el último de su pueblo (mohicano).

${ }^{30}$ Allan Pinkerton, escocés que emigró a Estados Unidos, fue nombrado el primer policía de Chicago. En 1850 fundó la primera agencia de detectives privados con otros socios, la North-Western Police Agency, que acabó por convertirse en la Agencia Pinkerton. Escribió numerosas novelas en las que describía su oficio, lo que ayudó a crear una leyenda en torno a su figura y su trabajo. The Expressman and the Detective (1874); Claude Melnotte as a Detective, and Other Stories (1875); The Spiritualists and the Detective (1876); The Mollie Maguires and the Detectives (1877); Strikers, Communists, Tramps and Detectives (1878); Criminal Reminiscences and Detective Sketches (1978); Mississippi Outlaws and the Detectives; Don Pedro and the Detectives; Poisoner and the Detectives (1879); Bucholz and the Detectives (1880); The Spy of the Rebellion (1884), entre otras. 
[...] a diferencia de la escuela inglesa, los protagonistas eran personajes poco intelectuales cuyas habilidades eran no la capacidad de raciocinio sino el disfraz, la persecución y la pelea. Aunque siempre se desenvolvían con una moralidad intachable, los forajidos empezaron a sustituir a los héroes del western en las dime novels, [...] (Gonzáles López, 2004: 69).

Con el tiempo, van surgiendo diferentes combinaciones en las que el forajido se convierte en detective y el investigador tiene que pasar a ser un fuera de la ley para resolver un caso. Esta situación supone que los personajes comiencen a presentar la ambigüedad del detective de la novela negra (González López, 2004).

La técnica narrativa utilizada en la hard-boiled se basa en la imagen. Se da menos importancia a las palabras, se trabaja en escenas fragmentando la realidad. La imagen facilita una narración que representa la dureza de la sociedad de su momento. Así, los nuevos relatos:

[...] resaltan la acción, la angustia y la violencia en detrimento de la resolución del crimen a la que convierten en un mero pretexto para resaltar las tareas de una sociedad delictiva y para ello, recurren a menudo a la narración homodiegética en focalización externa. Es decir, una escritura behaviorista con un narrador que pertenece a la diégesis, a la historia, pero que no cuenta más que lo que sabe, lo cual favorece la identificación y los golpes de sorpresa. Es decir un relato en primera persona (López Martínez, 2006: 20).

Carroll John Daly31_32 (1889-1958) es conocido por su detective Race Williams ${ }^{33}$, como primer autor de hard-boiled. Sin embargo, los máximos exponentes de esta tendencia, eminentemente estadounidense, son Raymond Chandler (1888-1959) y Dashiell Hammett (1894-1961). Eric González (2016)

\footnotetext{
${ }^{31}$ Daly escribió para Black Mask (H.L. Mencken y George Jean Nathan, 1920), una revista pulp que en sus orígenes publicó sobre diferentes temáticas: aventuras, misterio, detectives, románticas, lo oculto. Esta revista tuvo una influencia determinante sobre el género porque admitían y rechazaban originales, además de hacer sugerencias sobre los relatos (González López, 2004).

${ }^{32}$ Three Gun Terry (1923) es la primera novela negra publicada por Daly, en ella aparece el detective Terry Mack; Knight of the Open Palm (1923) es la primera novela de Race Williams.

33 Es considerado el primer detective privado (private eye): duro, solitario y violento. Servirá de inspiración a Dashiell Hammett para su personaje de Sam Spade.
} 
afirma que «sin los personajes de Dashiell Hammett, en especial el agente gordo y anónimo de Cosecha roja y el detective de El halcón maltés, y sin el prodigio de su prosa acerada, tal vez Raymond Chandler habría sido un simple publicista alcohólico y Marlowe no habría existido» (González, 22 de agosto de 2016: en línea). De hecho, el cine ha contribuido a popularizar más, si cabe, el género negro y sus personajes, modificando, incluso, los originales. Sam Spade «sólo es leal al trabajo y los colegas de profesión. No pertenece a ninguna clase social, es más joven y físicamente más atractivo que el agente, pero su impiedad resulta cruel y es el más inmoral de los dos, es capaz de enamorarse de una mujer aunque nunca anteponer el amor a las obligaciones profesionales» (James, 2009 [2010]: 44). Este personaje de Hammett siempre tendrá el físico de Humphrey Bogart, que también dará vida a Phillip Marlowe, a pesar de que Raymond Chandler declaró que lo imaginaba con el físico de Cary Grant. A pesar de ello, en el imaginario colectivo quedan inevitablemente unidos Marlowe-Spade y Bogart (Imagen 1), aunque haya otros actores que también los hayan interpretado (Imagen 2). Este fenómeno resulta muy interesante porque se inicia una sinergia entre el género negro y el cine que tiñe la historia y la palabra de la fuerza de la imagen, hecho que se prolongará e intensificará con posterioridad.

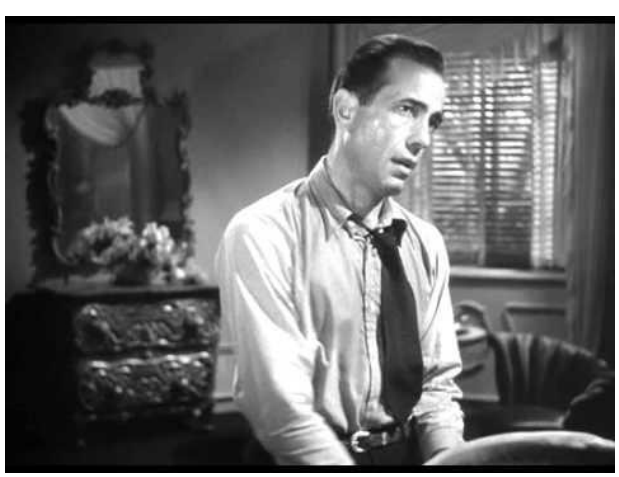

Imagen 1. Humphrey Bogart (1946)

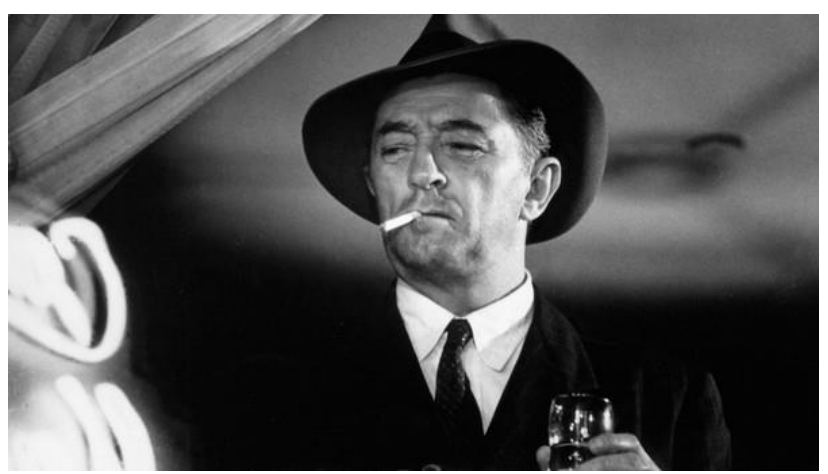

Imagen 2. Robert Mitchum (1975) ${ }^{34}$

\footnotetext{
${ }^{34}$ Las imágenes muestran a dos de los actores que han interpretado el personaje de Phillip Marlowe. A la izquierda, Humphrey Bogart interpreta a Phillip Marlowe en El sueño eterno (The Big Sleep, Howard Hawks, 1946). A la derecha, Robert Mitchum interpreta a Phillip Marlowe en Adiós muñeca (Farewell, My Lovely, Dick Richards, 1975). Posteriormente, interpretaría el mismo personaje en otra adaptación de The Big Sleep, Detective privado (The Big Sleep, Michael Winner, 1978).
} 
Ross MacDonald ${ }^{35}$, seudónimo de Kenneth Miller, (1915-1983) es considerado uno de los herederos de Hammett y Chandler. Su detective Lew Archer es un delincuente que se convierte en «agente de la ley», siguiendo el ejemplo de otros personajes como Arsene Lupin. La producción de MacDonald se puede dividir en dos etapas: la primera plenamente hard-boiled, en la que impregna sus relatos de una gran dosis de violencia, y la segunda, más próxima a una novela negra realista, que busca respuesta al origen psicológico del crimen.

La novela negra hard-boiled está protagonizada por personajes «duros» que viven en un espacio urbano, con unos principios firmes pero en un entorno corrupto. Raymond Chandler, uno de los padres del género, expone los principios básicos sobre los que se debe construir al detective en la novela negra que desarrolla. Para el escritor es muy importante que el personaje del detective «exista completo y entero y que no lo modifique nada de lo que sucede; en tanto detective, está fuera de la historia y por encima de ella, y siempre lo estará» (Chandler en Martín Cerezo, 2006: 58). Precisamente, Chandler achaca a este hecho que al final de la historia el detective nunca se quede con la chica, ni tenga vida privada. Es representado como un individuo de fuertes principios «morales e intelectuales» que hace su trabajo ( cambio de unos honorarios escasos. Se presenta como el único individuo íntegro, que pelea por mantener la dignidad, en un entorno corrupto, por eso se mantiene, en cierto modo, al margen de la sociedad. Es un personaje que se mueve en un entorno urbano, con valores urbanos, pero el detective debe sobreponerse a las presiones que sufre en éste. Sus principios son tan fuertes que para conseguir el objetivo de proteger a los más débiles, si hace falta, es capaz de transgredir la ley, porque no es lo mismo legalidad y justicia, y el detective de Chandler representa

35 Algunos de los títulos de la serie de Lew Archer: El blanco móvil (The Moving Target, 1949), La piscina de los ahogados (The Drowning Pool, 1950), La forma en que algunos mueren (The Way Some People Die, 1951), La mueca de marfil (The Ivory Grin (aka Marked for Murder), 1952), En busca de una víctima (Find a Victim, 1954), Costa Bárbara (The Barbarous Coast, 1956), Los maléficos (The Doomsters, 1958), El caso Galton The Galton Case, 1959), La Wicherly (The Wycherly Woman,1961), El coche fúnebre a rayas (The Zebra-Striped Hearse, 1962), El escalofrío (The Chill, 1964), El otro lado del dólar (The Far Side of the Dollar, 1865), Dinero negro (Black Money, 1966), El enemigo insólito (The Instant Enemy, 1968), La mirada del adiós (The Goodbye Look, 1969), El hombre enterrado (The Underground Man, 1971), La bella durmiente (Sleeping Beauty, 1973), El martillo azul (The Blue Hammer, 1976). 
esta última, para lo cual puede llegar a matar. El detective, sin embargo, manifiesta cierta humanidad y puede ser manipulado o herido. El escritor es consciente de que este tipo de detectives sólo se encuentran en la ficción.

Obviamente, esta clase de detective no existe en la vida real. El detective privado de la vida real es un mezquino juez de la Agencia Burns, o un pistolero sin más personalidad que una cachiporra, o bien un picapleitos o un embaucador de éxito. Tienes más o menos tanta estatura moral como un cartel de tráfico (Chandler en Martín Cerezo, 2006: 59).

Chandler concluye este repaso sobre cómo debe ser la novela negra afirmando que «la novela policiaca no es y nunca será una novela sobre un detective. El detective entra sólo como catalizador. Y sale exactamente como era antes de entrar» (Chandler en Martín Cerezo, 2006: 59).

Este subtipo de novela negra no se basa en observaciones inteligentes, no se trata de dar respuesta a un «enigma», se trata de una respuesta más física, violenta. Los héroes (o quizás antihéroes) que protagonizan estas historias llegan a usar los puños en las peleas, sacan el arma y disparan. En este caso no sólo el criminal recibe la agresión, los detectives también son objeto de daño físico. La psicología de los personajes de la novela enigma suele situarse en sus características personales, en el caso de la denominada hard-boiled los personajes presentan una psicología torturada (alcoholismo, soledad, violencia, etc.). Lo más importante de este subtipo es la crítica social a la que no da una respuesta. El paisaje narrativo está poblado de gánsteres, delincuencia, miseria y desesperación que envuelven a unos personajes que no tienen esperanzas de poder salir de su desventurada e infeliz situación. Se trata de personajes individualistas y pesimistas. Estas novelas se centran en el detective, la víctima y el crimen, distanciándose de la investigación.

Otro elemento fundamental en este subgénero, y que resulta novedoso, es la incorporación de la femme fatale: una mujer es la desencadenante del crimen, suele ser un personaje sexualizado que provoca a los hombres y los empuja al crimen y la violencia. John Macklin (2006: 492) califica a este personaje como «siniestro, peligroso y amenazante». Este personaje «distorsiona los discursos 
tradicionales del amor, la familia, el romanticismo y la ley para explorar sus opuestos, es decir, el sexo, la avaricia, la violencia y el poder».

La filósofa Alicia Puleo (1997: 167) señala que «la Mujer es representada una y mil veces como fuerza ciega de la Naturaleza, realidad seductora pero indiferenciada, ninfa insaciable, virgen equívoca, prostituta que vampiriza a los hombres, belleza reptiliana, primitiva y fatal». Y es que los hombres han representado a las mujeres como santas o prostitutas dependiendo de si su conducta se ajustaba a las normas que imponían socialmente esos mismos varones (patriarcado ${ }^{36}$ ). Margarita Almela (2014) señala que

36 La definición clásica de patriarcado hace referencia al derecho que deriva de las legislaciones griegas y romanas que otorga al «padre» (en caso de fallecimiento de éste puede ser un hijo, un hermano...), como cabeza de familia de una «unidad doméstica», el poder legal y económico sobre todos sus miembros, incluidos otros varones. Sin embargo, el movimiento feminista cuestiona esta definición que pretende centrar el término entre la época clásica y el siglo XIX cuando las mujeres van adquiriendo derechos civiles, ya que la «dominación» es anterior a la antigüedad clásica y persiste después del XIX. Así, en el repaso que sobre el término hace Mํㅡㄹ Encarna Sanahuja Yll (2002) señala que será Kate Millet (1934- ) la primera en intentar redefinir el término. «Para ella no se trataba del derecho de los padres, sino del de los hombres, en general, y los maridos, en particular, derechos destinados a estructurar las relaciones de poder y de dominio sobre las mujeres, con la finalidad de garantizar a los hombres su ejercicio del control sobre aquéllas» (Sanahuja Yll, 2002: 17). Ya en los ochentas, la historiadora Gerna Lerner (1920-2013) amplia el concepto añadiendo a la apropiación de la sexualidad y capacidad reproductiva el profundo cambio en la organización de parentesco, relaciones económicas, aparición de la burocracia con la aparición de los estados y un panteón de nuevos dioses masculinos. Carole Pateman (1940- ) distingue tres formas de patriarcado: pensamiento patriarcal tradicional (el poder lo tiene el padre de la familia y el relato del nacimiento de la sociedad se hace a partir de esta realidad); teoría del patriarcado clásico (el poder político es paternalista y se justifica en el poder procreador del padre); patriarcado moderno (estructura la sociedad patriarcal paternalista, surge en el XVII y se basa en un contrato social paternal). En los noventa, Sara Morace habla de una «cadena ininterrumpida de coerciones que implicaban el uso de la fuerza y la presencia de especialistas para ejercerla» (Sanahuja Yll, 2002: 18). Es decir, el paso de sociedades «matrísticas» a patriarcales supone el desmontaje de grupos más igualitarios, libres, asamblearios... para dar paso a comunidades más desiguales, injustas, represivas... y donde prima la propiedad privada. Así pues, la definición del término patriarcado gira en torno al hecho de que los hombres determinan las relaciones de poder sobre el cuerpo femenino quedando las mujeres subordinadas, lo que convierte la reproducción y sexualidad de las mujeres como fundamentales. Victoria Sau (1930-2013) señala que «una toma de poder histórica por parte de los hombres sobre las mujeres, cuyo agente ocasional fue de orden biológico, si bien elevado éste a la categoría política y económica. Dicha toma de poder pasa forzosamente por el sometimiento de las mujeres a la maternidad, la represión de la 
[...] los hombres consideran a las mujeres inferiores y peligrosas (encarnación del mal y las fuerzas oscuras), las han sometido durante siglos (o tal vez milenios) a su dominio y han tratado de «compensar» esta consideración con una sublimación de un modelo de mujeres «ideal» que lleva en su origen una contradicción insalvable (Almela, 1994: 59).

De esta manera, se considera a las mujeres malvadas por naturaleza y se intenta dominar ese instinto, lo que les confiere ciertas virtudes (bondad, sumisión, pasividad...). Además, se intenta dar carta de naturaleza a esta virtuosidad como propia de las mujeres. Un mito que explica esta definición es el de Lilith, una demonio asiria cuya historia nos llega a partir de la tradición hebrea. Se representa como seductora y devoradora de hombres. Un espíritu maligno que atacaba a mujeres de parto y a los recién nacidos. En el siglo XII aparecen los primeros textos en los que describen a Lilith como la primera esposa de Adán. Esta compañera fue creada a partir de barro, como el propio Adán, no a partir de una costilla de éste. El relato señala que la pareja tenía continuos enfrentamientos porque ella no quería renunciar a su igualdad y cuestionaba la forma en que mantenían relaciones sexuales (Bornay, 1990). Es muy importante destacar este aspecto, ya que la huida del paraíso se produjo porque no quería mantener relaciones en una postura que consideraba poco digna, la denominada postura del misionero ${ }^{37}$. Lilith es una madre insubordinada, de hecho se la considera abiertamente hostil frente a la maternidad, lo que permite establecer esa dicotomía de mujeres malas versus mujeres buenas ${ }^{38}$ (Bornay, 1990; Almela, 2014). Esta diablesa que seduce a los hombres y los ataca en sus sueños presenta similitudes con la representación de la vampiresa que además de devoradora de

sexualidad femenina y la apropiación de la fuerza de trabajo total del grupo dominado, del cual su primer pero no único producto son los hijos...» (Sau en Sanahuja Yll, 2002: 19).

${ }^{37}$ Es fundamental en las sociedades patriarcales el control de la sexualidad de las mujeres, de ahí que resulte tan importante que establezcan, incluso, la forma correcta de mantener relaciones, no sólo el contexto (matrimonio), el lugar, etc.

${ }^{38}$ Las mujeres buenas serían aquellas que siguiendo su naturaleza se entregan plenamente a la maternidad. Una maternidad que llega a relacionarse con la pureza mediante la figura de la Virgen María en la iconografía cristiana. 
hombres es ambiciosa (suele buscar la estabilidad económica) ${ }^{39}$, una figura muy representativa del género negro.

La femme fatale es «una mujer destinada o condenada (según se vea desde una óptica u otra) a ser peligrosa y atractiva para los hombres» (Sánchez-Verdejo, 2014: 230). Será a mediados del siglo XIX cuando aparece el arquetipo ${ }^{40}$ literario que conocemos hoy día, aunque su origen lo encontramos en el personaje de la condesa de Adelaida en la obra de Goethe (Johann Wolfgang von Goethe, 17491832), Götz von Berlichingen (1773). Bornay (1990) menciona otros ejemplos, también en la época romántica, como Matilde, la protagonista femenina de $E l$ monje (The Monk, 1796), de Matthew Gregory Lewis (1775-1818), en ambos casos se le opone un personaje femenino puro, devoto, es decir, modelo de mujer de la sociedad patriarcal, en el primero la antagonista será María y en el segundo Antonia.

Uno de los elementos característicos de esta femme fatale es su belleza, su atractivo sensual y sexual. No interesa la capacidad intelectual del personaje (que, si atendemos a su habilidad para manipular a los personajes varones, la tiene) únicamente el aspecto físico que la sitúa en una posición de cosificación. Es importante entender, como hemos apuntado con anterioridad, que este personaje surge de la mente masculina que lo coloca como objeto de sus fantasías. Su belleza se equipara a un perverso canto de sirena que hipnotiza a aquellos con los que trata, así que el investigador está indefenso ante sus armas de seducción: una melena larga y abundante, en muchas ocasiones pelirroja, y una piel blanca. La

\footnotetext{
${ }^{39}$ Frente a la figura de Lilith aparece la figura de Eva, la segunda mujer de Adán, creada a partir de una costilla de éste, y que representa una mujer más sumisa. A pesar de ello, atendiendo a su naturaleza malvada tentó a Adán para que comiera del árbol del Bien y del Mal. Un fruto que si lo comían hacía que adquiriesen los conocimientos que poseía Dios, lo que suponía un claro desafío a su autoridad. La Biblia indica que nada más comer la manzana fueron conscientes de su desnudez y buscaron taparse con unas hojas de higuera, porque estaban avergonzados. Por su pecado, fueron castigados con la expulsión del paraíso. A Adán le incrementó la pena haciendo que se ganara el pan con el sudor de su frente y al morir volviera al polvo, y a Eva la condenó a parir con dolor y a la sumisión a su marido. Nuevamente, vemos que la representación de la sociedad patriarcal se dirige a controlar la sexualidad de las mujeres (Almela, 2014).

${ }^{40} \mathrm{El}$ arquetipo es un personaje que no se puede reemplazar en un argumento y que es reconocible por parte de la lectora y lector para decodificar la narración.
} 
«mirada» es plenamente masculina ${ }^{41}$. A pesar de que se trata de personajes que no se limitan al espacio de la maternidad que les asigna la sociedad, están creados para el «disfrute del hombre». En cierto modo, este personaje, la femme fatale, es una mujer que desea ser mirada, respondiendo a una ilusión de la mirada de los varones (Fuentes Herbón, 2014).

Estos personajes son parte del problema al que se pretende dar respuesta en las historias del género negro. Se representan como una amenaza para el detective protagonista, ya que puede nublar su profesional juicio. Con su belleza y poder de seducción, suelen ser «mucho más jóvenes que los detectives, mezclan la sensualidad, la independencia y la audacia» (Balogh, 2011: 250). Pueden estar directamente involucradas en el crimen o mantener una postura ambigua frente a éste lo que la convierte en una amenaza para la investigación o el detective. Ana María Balogh señala esta evidencia como una parte del éxito del género negro (sobre todo en cine, pero también en literatura, como más adelante indicaremos, muchas de las obras cinematográficas son adaptaciones de textos literarios). «Seguramente se encuentra ahí otra de las claves de éxito del género: la coexistencia de las dos fuerzas temáticas, erotismo y crimen, que remiten a los universales semánticos, vida y muerte, así como a las dos pulsiones freudianas: Eros y Thanatos» (Balogh, 2011: 250).

41 Este punto nos parece especialmente relevante, ya que defendemos una posición afirmativa sobre el hecho de que la literatura, en especial las novelas, contribuye a la construcción del imaginario de la sociedad. Así, el personaje de la femme fatale se convierte en una figura transgresora que puede ayudar al cambio de mentalidad, si se reconoce el poder que ostenta. Este personaje tiene en el cine el medio en el que mejor se puede representar, por ello utilizamos la reflexión de Berger (1974 [2000]) que señala que es una falacia que los medios de comunicación reflejen la realidad. La imagen que transmite está mediada por un ser humano que está tras la cámara y que toma decisiones sobre qué perspectiva adoptar, qué encuadrar, etc. Pensemos, por ejemplo, en una forma extrema de neorrealismo italiano (1945-1950 aprox.) en la que se coloca una cámara en una calle y se graban los pies de las personas que pasan. La realizadora o realizador ha tenido que tomar decisiones como la calle en la que coloca la cámara, la posición, el tiempo de rodaje, el tipo de plano, etc. Todas esas decisiones construyen un discurso que está determinado por la experiencia anterior (personal y profesional) de ésta o éste. Así, se produce una retroalimentación: por un lado, la literatura está influida por la realidad de la autora o autor $\mathrm{y}$, al mismo tiempo, la sociedad puede verse influida por las representaciones que aparecen en las novelas, que pueden reforzar o debilitar nuestras creencias, como veremos a lo largo de esta tesis. 
Hemos comentado que el personaje de la femme fatale encaja perfectamente en el cine, cuya representación, desde sus orígenes, según Vicente Benet (2006: 118):

[...] cumple una función determinante desde la vertiente de la «imaginería» del género: saca a colación la fotogenia, la sofisticación la imagen glamourosa ligada a las figuras femeninas que permite contrapesar los ambientes sórdidos, sobrios e imaginariamente precarios para el placer de la mirada que dominan la narración.

Al mismo tiempo, continúa Benet (2006: 118), la femme fatale ofrece «al público femenino de la época algunas vías de reconocimiento y satisfacción a través de los vestidos, los peinados y los comportamientos audaces de ese tipo de figuras».

La industria cinematográfica encontró en la novela negra un yacimiento de ideas para sus producciones. Las adaptaciones de novelas de este género a la gran pantalla fue una constante $y$, como hemos señalado, algunos de estos escritores (Raymond Chandler, Dashiell Hammett) incluso trabajaron en la industria de Hollywood como guionistas. El personaje de la femme fatale se hace carne en la figura de las actrices del cine clásico y de la misma manera que Phillip Marlow se identifica con Humphrey Bogart, Vivian Sternwood será Lauren Bacall (Imagen 3). Esta imagen se actualiza en la última versión rodada de L.A. Confidential (Curtis Manson, 1997), basada en la novela de James Ellroy (1948- ) del mismo título, con la actriz Kim Basinger (Imagen 4). Las directoras y directores no dejan al azar la construcción de estas mujeres fatales y se preocupan de colocar la luz adecuada que «hace las veces de un escultor enamorado con [sic] las protagonistas, el rostro joven y bello de las actrices aguanta bien los focos de luz que los enfatizan» (Balogh, 2011: 252-253). La luz ayuda también a crear un entorno en el que el personaje de mujer fatal atrae la mirada del detective, y el resto de personajes masculinos, construyendo un juego de seducción y provocación a tres bandas (detective-femme fatale-público) ${ }^{42}$.

${ }^{42}$ El público es relegado a una posición pasiva de voyeur que, sin embargo, puede transformarse en un papel activo, a nuestro juicio, al utilizar a estos personajes como modelos conductuales (física, psicológica y moralmente). 


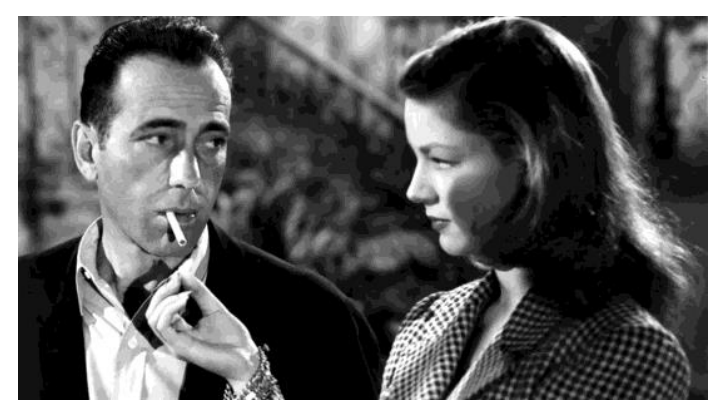

Imagen 3. Fotograma El sueño eterno (The Big Sleep, Howard Hawks, 1946)

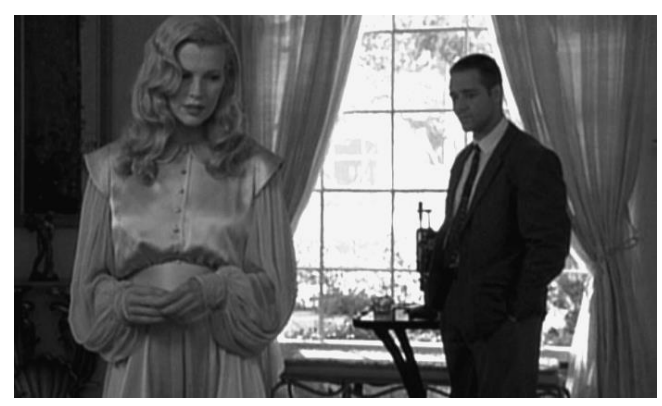

Imagen 4. Fotograma L.A. Confidential (Curtis Hanson, 1997)

Cerqueiro (2010) sitúa el fin de este género, hard-boiled, en Estados Unidos con Ross MacDonald (Kenneth Miller), creador del detective privado Lew Archer que ya hemos comentado con anterioridad. El salto de este subtipo de novela negra a Europa se produjo de la mano de George Simenon (1903-1989) en Francia, aunque con matices, pues se elabora una novela más costumbrista no tan centrada en la denuncia social como la estadounidense. Además el autor belga alarga la captura del criminal al que la lectora y lector conoce desde el principio, un juego de intriga que se hará común en el género más adelante ${ }^{43}$. No será hasta la década de los sesenta cuando al albur de las reivindicaciones de los movimientos sociales se introducirá la crítica social como elemento reconocible, especialmente en Francia. De ahí que este subtipo del género se asocie habitualmente con la novela negra norteamericana, mientras que la novela enigma, policiaca, detectivesca, se vincula con el género desarrollado en Europa.

A continuación, nos aproximaremos a cómo se desarrolla el género negro desde mediados del siglo XX hasta nuestros días.

\footnotetext{
${ }^{43}$ Simenon es un caso particular, ya que la extensión de tiempo durante la que desarrolla su producción literaria es tan amplia que cubre otros subtipos de novela negra, es decir, hace que su personaje, el inspector Maigret, empiece con un discurso del género clásico, pase por la crítica social y desemboque en novelas de corte más psicológico.
} 


\subsection{Novela negra desde mediados del siglo $\mathrm{XX}$ hasta la actualidad}

La evolución del género negro ha sido y es muy rápida, y sobre todo se ha visto influida por el cine. A mediados del siglo XX, se añade un elemento más a la novela negra: el suspense, al que hay que añadir los asesinos en serie.

Robert Block (1917-1994), con la publicación de Psicosis (1959), abre un nuevo camino para el género. A éste se suman Jim Thompson (1906-1977) con El asesino dentro de mí (The Killer Inside Me (1952)), Patricia Highsmith (1921-1995), con El talento de Mr. Ripley (The Talented Mr. Ripley, 1955) o Gerold Frank (19071998), que en El estrangulador de Boston (The Boston Strangler, 1966) describe los asesinatos de Alberto De Salvo (1931-1973) ${ }^{44}$.

Alfred Hitchcock (1899-1980) desarrolla en el cine los elementos que se adaptan perfectamente a la novela negra. El director británico rueda más de cincuenta películas. Acostumbrado a controlar todas las facetas de la producción no suele firmar los guiones, sólo en los inicios de su carrera en Gran Bretaña, y posteriormente reconoce que prefiere que ese trabajo lo hagan otros (Truffaut, 1966[1974]). A pesar de ello, reconoce que se involucra en los libretos porque considera que si fuera un texto exclusivamente de otros no podría convertirlo en éxito (el suspense y el clima son una creación suya). Hitchcock se jacta en la entrevista con el director francés de que no mira por el visor o repasa el guión durante el rodaje porque lo conoce a la perfección. Él planifica la película plano a plano, con anterioridad al rodaje, para poder construir el clima de intriga y misterio que le caracteriza. Su filmografía se basa, sobre todo, en obras literarias, para lo que explicaba al guionista colaborador cómo quería que fuera la historia. Sus adaptaciones no pretenden ser un fiel reflejo de los libros, sino su propia interpretación ${ }^{45}$. Entre los guiones que adapta de novelas de escritoras y escritores

\footnotetext{
${ }^{44}$ Asesino en serie que confesó haber matado a 13 mujeres en el área de Boston (Massachusets, Estados Unidos).

${ }_{45}$ "A menudo se habla de los cineastas que, en Hollywood, deforman la obra original. Mi intención es no hacerlo nunca. Yo leo una historia sólo una vez. Cuando la idea de base me sirve, la adopto, olvido por completo el libro y fabrico cine. Sería incapaz de contarle Los pájaros de Daphne du Maurier. Sólo la he leído una vez y rápidamente. Lo que yo no
} 
destacaremos: Rebeca (1938), de Daphne du Maurier (1907-1089), una novela negra atravesada por el misterio y rasgos psicológicos que permite crear una historia multidimensional. También utilizó la novela Extraños en un tren (1950), de Patricia Highsmith (1921-1995), una de las principales escritoras de novela negra, o Marnie (1961), de Winston Graham (1908-2003), otro relato de corte psicológico, que se desarrolla en un ambiente de suspense.

En este nuevo subtipo de novela negra, la víctima se convierte en el centro de la historia, apareciendo nuevos subtipos como las «novelas del miedo», «novela de la víctima» o «novela de suspense». Se trata de un tipo de novela que se extiende tanto en Estados Unidos como en Europa. Lo más importante de estos relatos es la «atmósfera», intangible, pero que se siente cuando algo perturba la tranquilidad de lo cotidiano. Ese «algo» es un elemento que había estado reprimido, por cualquier razón. Generalmente, la víctima siente que está enredada en una conspiración y la resolución suele ser irracional, sujeta a las pulsiones básicas del ser humano. La angustia que provoca en la lectora y lector es la palabra que mejor define este subtipo.

En los años sesenta podemos destacar a la autora Carolyn Gold Heilbrun (1926-2003). Es una profesora universitaria estadounidense, la primera que consiguió la titularidad del departamento de inglés de la Universidad de Columbia. Reconocida feminista firma sus novelas negras con el seudónimo de Amanda Cross. Su producción de ficción negra la protagoniza Kate Fansler (1964-2002), una profesora de inglés que desarrolla su actividad detectivesca en el ámbito académico que tan bien conoce la escritora a través de la relación con los personajes alejándose de la violencia que se va imponiendo en el género negro a partir de este momento. En sus novelas indaga sobre temas feministas y de diverso calado social, como los conflictos que se producen en el ámbito académico.

comprendo es que alguien se apodere realmente de una obra, de una buena novela cuyo autor ha empleado tres o cuatro años en escribir y que constituye toda su vida. Se manipula el asunto, se rodea uno de artesanos y de técnicos de calidad y ya tenemos candidatura a los «óscars», mientras que el autor se diluye en segundo plano. No se piensa más en él» (Truffaut, 1966 [1974]: 57). 
Santaulàlia i Capdevila (2005b) considera que no se la puede considerar todavía como una escritora feminista ${ }^{46}$.

Desde la década de los sesenta cada diez años aproximadamente puede decirse que las tramas se centran en un aspecto diferente: en los sesenta se politizan, en los setenta surge la reivindicación violenta, en los ochenta las historias se centran en la historia, en los noventa la influencia de las snuff movies abre la puerta a los asesinos en serie que nacen en Estados Unidos y pronto son imitados en Europa, y nos encontramos ante relatos gore (López Martínez, 2006).

Así veremos, en un primer momento a Truman Capote ${ }^{47}$ (1924-1984) como uno de sus mayores exponentes de estas nuevas formas del género, empezando con A sangre fría (In Cold Blood, 1966) que inaugura una nueva corriente periodística que consiste en novelar crímenes reales, se conoce como nuevo periodismo. A sangre fría es la culminación de años de investigación sobre el atroz crimen de la familia Clutter en Holcomb (Kansas). En los setenta, destacará Stephen King (1947- ) con El resplandor ${ }^{48}$ (The Shining, 1977), que aúna la psicología criminal, el terror fantástico y el suspense. Para esta novela se inspira en el relato de Edgar Allan Poe, «La máscara de la muerte roja» (The Masque of the Red Death, 1842). En los ochenta, cuando el criminólogo y agente del FBI, Robert K. Rossler (1937-2012) acuña el término «asesino en serie» da pie a un subtipo de novela negra. Con la novelización de los asesinatos de Ted Bundy ${ }^{49}$ (1946-1989) por parte de parte Richard W. Larsen (1951-2008) y la irrupción en el panorama editorial de Thomas Harris (1940- ) el género avanza enormemente.

\footnotetext{
46 Para esta autora, la primera escritora de novela negra propiamente feminista es P.D. James, como veremos más adelante.

${ }^{47}$ Truman Capote cultiva diferentes géneros literarios tanto de ficción como ensayísticos. Algunos títulos destacados: Un árbol de noche y otros cuentos (A Tree of Night and Other Stories, 1949), El arpa de hierba (The Grass Harp, 1951) o Desayuno en Tiffany's (Tiffany's Breakfast, 1958).

48 La adaptación cinematográfica se llevará a cabo en los años ochenta, de mano del director Stanley Kubrick (1928-1999).

${ }^{49}$ Asesino en serie, secuestrador, violador, ladrón y necrófilo que asesinó a mujeres jóvenes durante los años setenta.
} 
Thomas Harris sitúa como protagonistas de su serie Lecter ${ }^{50}$ al psiquiatra asesino Hannibal Lecter. La primera de las novelas de la saga es El dragón rojo (Red Dragon, 2002), que quiebra los límites del género hasta el momento y hace que la novela negra se convierta en más violenta, más caótica, más oscura e inquietante. A este autor se le suman muchos otros entre los que destacaremos a Michael Connelly (1956- ) que tiene una importante producción dividida en tres series: Harry Bosch (1992- ) la más importante que está protagonizada por un policía veterano del departamento de Los Ángeles; Mickey Halley (2005-2013) y Jack McEroy (1996 y 2009). A la que hay que sumar algunos títulos no seriales.

También contribuye de manera decidida a este subtipo James Ellroy (19461989), que explora la psicopatología del acto criminal (Horsley, 2005: 147), La Dalia Negra (The Black Dhalia, 1987) es uno de los ejemplos más importantes de este autor. Phillip Kerr (1956- ) sitúa la acción de sus novelas negras en un futuro apocalíptico, Una investigación filosófica (A Philosóphical Investigation, 1992). Ian Rankin (1960- ) ha creado dos series de novela policiaca: John Rebus ${ }^{51}$ (1987- ) y Malcolm Fox (2009 y 2011). Para cerrar este breve repaso sobre la evolución de la novela negra en la segunda mitad del XX, mencionaremos a Bret Easton Ellis (1964- ) y su novela American Psycho ${ }^{52}$ (1991), en la que vemos a un Patrick Bateman que desdobla su personalidad: un hombre de éxito en los negocios y un asesino en serie caníbal.

La novela negra, a diferencia de otros géneros literarios, no evoluciona de manera lineal como ha sucedido anteriormente, de forma que un movimiento con características propias sustituye al anterior que presenta características diferentes. La novela negra mantiene sus subgéneros actualizados y conviven en el tiempo. Es decir, la novela enigma convive con la hard-boiled, y ésta con el nuevo híbrido de género negro actual, del que hablaremos más adelante. El género

\footnotetext{
${ }^{50}$ La serie fue adaptada al cine en 1991 con El silencio de los corderos (Jonathan Demme) y Hannibal (Ridley Scott, 2001), y más recientemente se ha convertido en serie de televisión Hannibal (NBC, 2013-2015).

${ }^{51}$ La adaptación televisiva la realizó la BBC y duró en emisión cuatro temporadas (catorce episodios) entre 2000 y 2007.

${ }^{52}$ La adaptación cinematográfica fue dirigida por Mary Harron en 2000.
} 
evoluciona, pero no abandona los subtipos anteriores cuya publicación está relaciona con el fenómeno fan que comentábamos anteriormente o con criterios editoriales (aquí sinónimo de comerciales) (Cerqueiro, 2010; Martínez López, 2006; Resina, 1997; Rodríguez Pequeño, 1995).

En la actualidad, conviven diferentes subtipos de novela negra que se retroalimentan los unos a los otros gracias a la rapidez con que se difunden las nuevas publicaciones. Pasemos a ver el ejemplo de la novela negra nórdica.

Kerstin Bergman (2014) analiza los factores que están detrás del éxito de la novela negra nórdica ${ }^{53}$ que resume como: el efecto Stieg Larsson, la crítica del estado de bienestar, la representación de temas relativos a la igualdad de género y la fortaleza de los personajes femeninos, los escenarios y paisajes exóticos. La denominación Nordic Noir hace referencia a la literatura de género negro más allá de un ámbito geográfico concreto. Bergman (2014: 80) afirma que estas novelas pueden producirse en cualquier parte, desde las zonas rurales de Islandia a Estocolmo y Copenhague, pero también en Asia, África, Europa, América del Sur, Australia, Estados Unidos o Canadá. Es un amplio concepto que incluye todos los subtipos del género que hemos comentado anteriormente (desde el relato enigma a la novela suspense). Además, no es exclusivo de la literatura, incluye también la producción televisiva y cinematográfica.

Cronológicamente aparece de la mano del matrimonio formado por Maj Söwall (1935- ) y Per Wahlöö (1926-1975) en los años sesenta. En su obra se puede observar un tratamiento psicológico de los personajes y detalles de la investigación. Sitúan sus novelas en la realidad de la sociedad en la que viven y empujan a la lectora y lector a cuestionarse el entorno. Escribir su saga sobre el inspector Martin Beak fue, en palabras de Söwall, «un proyecto que los dos

53 La novela negra nórdica ha sido denominada, a efectos de comercialización: Scandinavian Crime Fiction, Scandicrime, Le polar polaire, o Schwedenkrimi, y, más crecientemente, Nordic Noir. Eva Parra Membrives (2013: 550) señala: «En cierto modo, la novela policíaca nórdica - sin entrar ahora en consideraciones de género- ya se define de forma local al emplear en su nomenclatura criterios geográficos y no temáticos, como sí hace la novela criminal hard-boiled o la novela de ciencia-ficción policial, por ejemplo». 
teníamos claro que debía tener un principio y un fin. Con esas obras queríamos denunciar una Suecia que de cara al exterior era idílica y que para nosotros, que la estábamos viviendo, era una absoluta degradación de lo que habíamos imaginado» (Söwall en Intxausti, 24 de enero de 2013: en línea). La escritora sueca es muy crítica con el actual boom de la novela negra nórdica, que es una de las que más ha crecido en los últimos años.

Pero Bergman señala que el término noir (negro), hace referencia a los oscuros inviernos nórdicos (días cortos y noches largas), de este modo, la climatología se convierte en un elemento fundamental (frío, lluvia, nieve) y los paisajes helados, que son una metáfora de paisajes interiores que definen a los personajes como fríos y con tendencia a la depresión. Esto se observa en personajes como el detective Wallander, creado por Henning Mankell, un policía divorciado agobiado por su vida familiar (relaciones tormentosas con su hija y su padre), con tendencias depresivas, que vive en Ysyad (Malmö, Suecia) o Rebeccka Marthisson, la abogada metida a investigadora de Åsa Larsson, fría, independiente y adicta al trabajo, que deja Estocolmo por un pequeño pueblo sueco, Kiruna, donde se «esconde» adormecida, y semi-recluida.

Por otro lado, Bergman (2014) habla del prejuicio que existe en cuanto a que la novela negra nórdica es violenta. Sin embargo, considera que no es así y que la etiqueta le viene de la saga Millenium, de Stieg Larsson en la que la protagonista femenina es brutalmente violada y con posterioridad ella se venga, a pesar de que no se describa la escena de manera detallada.

In Larsson's text, these rape scenes are short and not very explicitly described. Nevertheless, they have become the most widely discussed scenes of Nordic crime fiction, and as they have been used to illustrate the abundance of graphic violence in crime fiction in general, they have gathered a reputation that has very little to do with what is actually present in Larsson's novel (cf., Horeck, Gregersdotter, and Åström 4) (Bergman, 2014: 82).

Centrándonos en los cinco factores definitorios de la novela negra nórdica, podemos empezar por el denominado efecto Stieg Larsson. El gran éxito de la saga Millenium ha provocado que numerosas editoriales seleccionen otras autoras (y autores) nórdicas, porque «readers and publishers both seem to perceive the 
geographical origin and the comparisons with Larsson as an emblem of quality» (Bergman, 2014: 83-84). La investigadora señala que, en algunos casos, ese criterio de espejo podría decepcionar a las seguidoras y seguidores de este género negro nórdico. Sin embargo, considera que las buenas traducciones que se hacen de estas novelas salvan del desencanto. Pone como ejemplo que «Henning Mankell's and Camilla Läckberg's language, in both cases a quite simple language in the Swedish originals, often becomes more aesthetically advanced in the English translations by Laurie Thompson (Mankell), Steven T. Murray (Läckberg), and Tiina Nunnally (Läckberg)».

El segundo factor es la crítica del estado del bienestar, que está relacionado con la intención que señala Maj Sowäll unas líneas más arriba: su crítica social y política acaba por «politizar el género». Aunque no todas las escritoras y escritores presentan este compromiso, la mercadotecnia editorial hace que el público tienda a creer que es así. Además, fuera del entorno nórdico se siente curiosidad por conocer este reputado estado de bienestar (ahora en proceso de desmantelamiento). Este atractivo se ve satisfecho porque la novela negra nórdica es realista y describe la sociedad contemporánea (sólo ocasionalmente introduce elementos históricos).

El tercer factor está relacionado con la igualdad de género y la fortaleza de los personajes femeninos. Bergman (2014: 85) hace referencia al hecho de que muchas de las autoras son mujeres y escriben sobre protagonistas también mujeres. Aquí se produce una aproximación diferente del público lector nórdico y el internacional. Mientras el primero ve a los personajes de las novelas como estereotipados y consideran que todavía tienen mucho camino por andar, en el exterior gusta leer sobre «gender equality, and reading about women who combine career and family or men who take parental leave, cook for their family, and clean the house» como si ya se hubiera conseguido esa igualdad.

Los escenarios y paisajes exóticos están relacionados con la simbología del paisaje inhóspito que remite al estereotipo de personalidad fría y depresiva. Bergman (2014: 85) señala este elemento como marca de identidad que transciende a lo literario, por ejemplo se puede observar en las portadas de muchas de estas novelas (Imagen 5). También en las adaptaciones de estas sagas 
de novela negra a la televisión se observa la preeminencia de estos paisajes tan áridos como reflejo de la personalidad de los personajes. Es el caso, que mencionábamos antes, de la serie que la BBC realizó de la saga Wallander de Henning Mankell (1948-2015), la serie de Fjällbacka (de Erica Falck y Patrick Hedström) de Camilla Läckberg (1974- ) fue adaptada por el realizador Daniel Lind Lagerlöf, o la serie de la abogada Rebecka Martinsson, de Asa Larsson (1966- ), ha sido adaptada para la televisión este mismo año (2017).

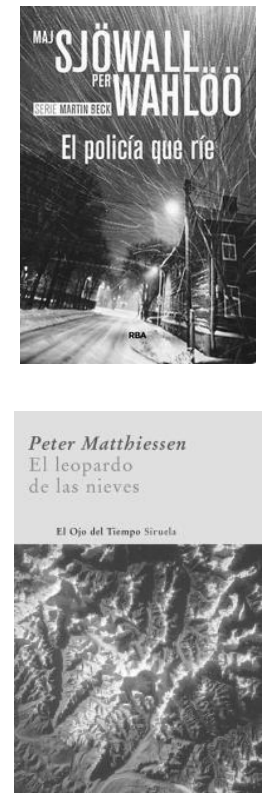

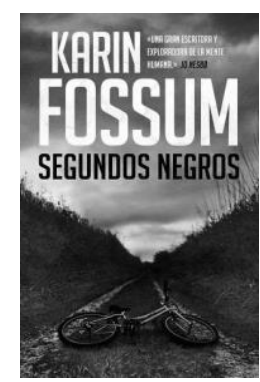

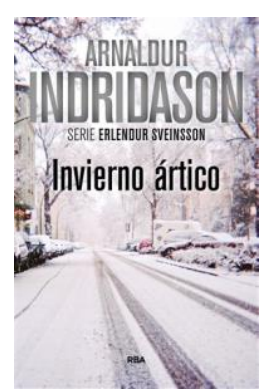

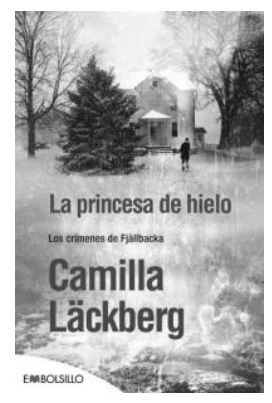

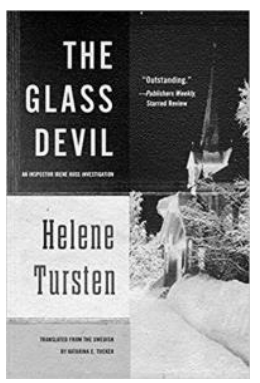

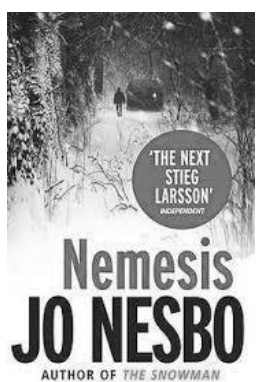

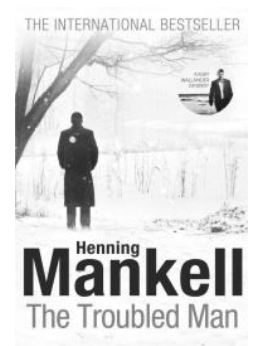

Imagen 5. Portadas de series de novela negra nórdica (de derecha a izquierda y de arriba abajo). El policía que ríe (Maj Sjöwall y Per Wahbo, 1968), Segundos negros (Karin Fossen, 2002), La princesa de hielo (Camilla Läackberg, 2002), Nemesis (Jo Nesbø, 2002), Aurora Boreal (Åsa Larsson, 2003), El leopardo de las nieves (Peter Mattiessen, 2004), Invierno ártico (Arnaldur Indridason, 2007), The Glass Devil (Helene Tursten, 2009), The Troubled Man (Henning Mankell, 2009), Le noyé dans la glace (Kjell Ola Dahl, 2014).

La influencia de la novela negra angloamericana, según Bergman (2014), queda patente en la novela negra nórdica y esto la hace fácilmente decodificable para la lectora y lector internacional, ya que se establece un equilibrio entre el exotismo que comentábamos antes y la comodidad de lo conocido. Así, el nordic noir se puede calificar como «confortable y familiar» para la lectora y lector.

Finalmente, Bergman (2014: 87) se centra en el denominado «Schwedish sin» y es la idea que la lectora y lector internacional tiene de que en las sociedades nórdicas se manifiestan actitudes más liberales sobre el sexo. La autora nos señala que es una creencia, ya que el tabú del sexo es igual a otras sociedades donde la religión es importante. 
Una vez descritos los factores que identifican la novela negra nórdica, nos preguntaríamos si es cierta la tesis de Bergman (2014) respecto al hecho de que estas mismas características se pueden rastrear en otras literaturas de género negro.

\subsection{Aproximación a las novelas negras periféricas. El caso de la novela negra japonesa, la novela negra africana y la novela negra en la India}

La popularidad de la novela negra no se circunscribe únicamente a las literaturas occidentales. Las literaturas periféricas ${ }^{54}$ también presentan autoras y autores que se dedican a este género, un ejemplo sería la novela negra japonesa, sobre la que realizamos una breve aproximación en lo que sigue. La novela negra llegó a Japón a principios del siglo XX, su denominación era Tantei Shôsetsu (ficción detectivesca), pero tras las Segunda Guerra Mundial se prohibió y surgió el Suiri Shotsetsu (ficción de razonamiento deductivo) que sigue los principios del whoudonit. La Biblioteca Nacional define el género negro japonés en los siguientes términos:

En Japón el género policiaco se engloba dentro de la literatura denominada «popular»y tiene diversas variantes o subgéneros perfectamente delimitados. Algunos de los más importantes son: Nazotoki: puede considerarse similar a la novela policiaca británica clásica (la trama se plantea como un juego de lógica donde el policía o detective protagonista utiliza el razonamiento deductivo para descubrir al culpable); Mado koirudo: la trama no se plantea como un juego de pistas, sino que tiene más elementos de acción y aventura; Shyakai ha: la trama relata conflictos relacionados con las distintas clases sociales que existen en Japón; Seishyun mono: se trata de una rama dedicada al público joven o adolescente. La acción suele tener lugar en colegios o universidades (Biblioteca Nacional, s.f.: en línea).

\footnotetext{
${ }^{54}$ Utilizamos el término «periferia», en este contexto, en sentido geográfico para referirnos a las literaturas que no se escriben en Europa o Estados Unidos. Las literaturas no mainstream que se publican en estos espacios geográficos también pueden ser denominadas periféricas, sin embargo, no utilizaremos esa acepción en esta tesis.
} 
Repasamos, a continuación, las principales escritoras y escritores del género negro japonés: Okamato Kido ${ }^{55}$ (1872-1939) y Taroou Hirai ${ }^{56}$ (1894-1965) son los primeros autores de novela negra japonesa. Okamato Kido opta por crear un personaje que recuerda a Sherlock Holmes, el detective Hanshichi. Sus aventuras se publicaron entre 1840 y 1860, un periodo en que Japón todavía está inmerso en la tradición que choca con la racionalidad del pensamiento de Hanshichi, «un retrato de las costumbres del Japón imperial, como, por ejemplo, que un samurái no puede creer en fantasmas» (Corroto, 15 de octubre de 2014: en línea). Ranpo Edogawa adquiere gran popularidad gracias a la introducción en sus historias de algo de obscenidad y un sutil erotismo revestido de un poco de fantasía. Las tramas de esta primera novela negra japonesa se caracterizan por seguir los cánones del género que se desarrollan en occidente, en el caso de Edogawa sus historias están inspiradas en Poe y Doyle. Fue el fundador de la Asociación Japonesa de Escritores de Misterio.

Igual que hemos visto que sucede en Europa y Estados Unidos la novela negra japonesa bascula hacia la hard-boiled representada en el escritor Ōyabu Haruhiko (1935-1996). Sus novelas, cuyo protagonista es el detective privado Kosuke Kindaicho, siguen la línea de las novelas negras occidentales ortodoxas.

Tras la prohibición será Seishi Yokomizo (1902-1981) quien recupera el género en la persona del detective privado más célebre en Japón: Kosuke Kindaichi. Sobre las novelas de Yokomizo «[...] hay incluso estudiosos como Nakagawa que defienden que sus libros no son simples divertimentos, sino que encierran cierta crítica a la cultura patriarcal y el sistema político tradicional nipón» (Vera, 13 de enero de 2017: en línea).

Matsumoto Seichō (1909-1992) sigue los pasos de Seishi y crea la Shyakai ha o novela negra con una vertiente más realista centrada en el conflicto social.

\footnotetext{
${ }^{55}$ El fantasma de Ofumi (Ofumi no tamashii), La farola de piedra (Ishi dôrô), La muerte de Kanpei (Kanpei no shi), El misterio de la campana de incendios (Hansho no kai), La doncella del daimyô (Oku jochû), Nieve de primavera (Haru no yukidoke), La mansión de las campanillas (Asagao yashiki), El guirigay de los gatos (Neko sôdô), La celebración del paso de la montaña (Yama iwai no yo), El caso del halcón desaparecido (Taka no yukue), entre otras.

56 Su seudónimo es Ranpo Edogawa.
} 
La popularidad del género negro en el país nipón hace que las mujeres incursionen en la novela negra con éxito, pues se convierte en una herramienta de crítica social y política como sucede en el género negro occidental. Etsuko Niki (1928-1986) es la primera escritora de novela negra, lo que supone un punto de inflexión en una sociedad que considera este género poco apropiado para las mujeres. Un hecho que tiene gran importancia en una sociedad tan tradicional como la japonesa, en la que la división sexual de los roles seguía estando presente; a Masako Togawa (1933- ) la han comparado con P.D. James. Sus libros más importantes son Lady Killer y La llave maestra, en sus novelas hace hincapié en el «comportamiento humano y sus consecuencias» (Corroto, 15 de octubre de 2014: en línea); Natsuo Kirino (1951- ), autora de Out (1997 [2003]), sitúa como tema central la violencia de la sociedad japonesa que ejerce una presión extrema sobre sus ciudadanas y ciudadanos. La novela funciona como exponente de los valores tradicionales de la sociedad japonesa, asfixiantes en una sociedad moderna también opresiva (cada vez es más difícil vivir con dignidad, tener un trabajo con el que mantenerse, etc.). Además, Kirino trata el tema de la defensa de la mujer en una sociedad con una gran violencia de género; Keigo Higashino (1958- ) y Miyuki Miyabe (1960- ) desarrollan su obras en paralelo a la producción de autoras norteamericanas como Patricia Cornwell (1944- ) o Sara Paretsky (1947- ); Miysuyo Kakuta (1967- ) plantea temas cotidianos como los problemas de vivir en la ciudad, la incomunicación, la fragilidad del individuo, a lo que añade su interés por la ecología; o Fuminori Nakamura (1977- ), que en su novela El ladrón (2012) opta por utilizar a un delincuente como protagonista. Tiene un estilo cinematográfico parecido a Kim Ki-Duk (1960- ).

La novela negra africana, sigue las características originarias de la novela negra, las escritoras y (los escritores) africanas utilizan sus historias para hacer una crítica social del mundo que les rodea. Sin embargo, el escritor senegalés Abassen Ndione afirma que hay una gran diferencia entre la novela negra europea y la africana: «"la novela negra europea tiene que imaginar para crear, la africana sólo ver". Los escritores europeos, aunque pretendan criticar la situación de África nunca sentirán en sus carnes aquello de lo que hablan, sus palabras jamás podrán 
expresar la rabia y la impotencia de quien palpa día a día la brutalidad policial, la injusticia y la pobreza» (Ndione en Heras, 10 de octubre de 2010: en línea).

Debemos tener en cuenta que África es un gran continente con una enorme diversidad cultural. Esto hace que el sustrato sobre el que se desarrolla el género no nos permita homogeneizar las novelas, sino que cada novela es diferente dependiendo del lugar de origen de la autora o autor. Laundry-Wilfrid Miampika (2009) apunta:

El escritor Yashmina Khadra (el que mejor ha reflejado la realidad y las consecuencias de la guerra civil en Argelia), el congoleño Achille Ngoye, el senegalés Abasse Ndione y el maliense Moussa Konaté no solo confirman la existencia de la novela negra en África negra, sino también demuestran un uso original del género, con la ventaja de entrever esa África negra desde un sombrío y violento pero inédito punto de vista» (Miampika, 18 de septiembre de 2009: en línea).

Para ejemplificar lo que es la novela negra en África referenciaremos de forma sucinta dos novelas: La malédiction du Lamantin (2009), de Moussa Konaté, y Ramata (2000 [2007]), de Abasse Ndine. La primera representa las características que hemos mencionado sobre la novela negra africana. El comisario Habib es un hombre educado en la racionalidad occidental, aunque no puede dejar de lado la tradición de su país. El compañero de Habib está más apegado a las creencias ancestrales, en algunos casos, supersticiosas. En La malédiction $d u$ Lamantin reflexiona sobre los problemas de África en general y Malí en particular: la situación entre la tradición y la cultura occidental, la corrupción política y policial. El relato presenta un análisis realista de la situación (Catoira, 2014). Ramata fue promocionada por su editorial como la Madame Bovary africana. Al igual que la anterior es un reflejo de una sociedad quebrada entre la racionalidad y la superstición, así como la corrupción que impregna todo el sistema. De forma relevante, el personaje central de esta novela de Ndine es una mujer, lo que supone la introducción de la situación de las mujeres en el continente africano en un marco de género negro.

¿Qué sucede en otras partes del mundo? La novela negra siempre refleja la sociedad en que nace. ¿Cómo se desarrolla el género en Asia? Si en África hay una 
gran fragmentación, las diferencias entre zonas geográficas diversas en el continente asiático nos llevan a realidades diametralmente opuestas.

El subcontinente indio, por ejemplo, aquejado de situaciones similares a las africanas plantea, para la novela negra india, temas comunes, pero su realización es diferente en cada autora o autor. Dora Sales Salvador (octubre de 2014) presenta las diferencias entre la novela negra de Vikram Chandra que «trasciende cualquier definición de narrativa policiaca» y Kalpana Swaminathan que «elabora un tipo de ficción detectivesca más clásica, en la línea de Arthur Conan Doyle, Agatha Christie o Wilkie Collins [...] Pero su aportación es fresca, convincente, entretenida. Y comprometida con la intención de denuncia social» ${ }^{57}$.

La evolución del género negro es constante, como vemos, ya que se trata de un tipo de novela que responde a la evolución social, actuando de alguna forma como una catarsis para la sociedad donde se escribe. Para las mujeres, es un género en el que despuntaron con las novelas policiacas clásicas, se diluyeron en las novelas negras hard-boiled y vuelven a surgir en el suspense, con autoras como: P. D. James (1920-2014), Mary Higgins Clark (1927- ) o Ruth Rendell (1930-2015). P.D. James es la madre de las series de: Adam Dalgliesh (1962-2008) y Cordelia Gray (1972 y1982). Cordelia hereda una agencia de investigación en la primera entrega, No apto para mujeres (An Unsuitable Job for a Woman, 1972) que continúa en La cadavera bajo la piel (The Skull Neneath the Skin, 1982). «Cordelia abrirá camino a una serie de novelas que, al otro lado del Atlántico en los años 80, transmutarán la fórmula hard-boiled al poner la investigación en manos (o sobre los tacones) de una mujer de armas tomar» (Santaulàlia i Capdevila, 2005b: 38). Es un personaje que permite plantear cuestiones feministas.

\footnotetext{
57 Dora Sales Salvador impartió la lección inaugural Voces indias contemporáneas: Manju Kapur y Kalpana Swaminathan, del Máster Universitario en Investigación Aplicada en Estudios Feministas, de Género y Ciudadanía, organizado por el Instituto Universitario de Estudios Feministas y de Género «Purificación Escribano», en octubre de 2014. Disponible en línea en: https://www.youtube.com/watch?v=St-Rg8PL0NE. Fecha de consulta: 8 de marzo de 2017.
} 
Mary Higgins Clark es una prolífica escritora con un estilo próximo al suspense. Por lo general, las protagonistas de sus novelas son mujeres jóvenes, inteligentes e independientes que se muestran prudentes en sus acciones. Algunas de sus obras: ¿Dónde están los niños? (Where are the children?, 1975), Acuérdate de mí (Remember me, 1994), Asesinato en directo (I've got you under my skin, 2014), entre otras.

Ruth Rendell sigue un subtipo de novela negra caracterizado por un «paisaje psicológico, escenario de traumas infantiles o comportamientos patológicos, espejo de fantasmas personales o sociales, o una cortina de humo que, al desvanecerse, revela los oscuros recovecos del alma humana» (Santaulàlia i Capdevila, 2005b: 38). Es la creadora de la serie del inspector Wexford (19642013) que inaugura con el título Dedicatoria mortal (From Doon with Death, 1964).

En la actualidad, con el boom del género un gran número de nombres de mujer se han sumado a la producción de novela negra con perspectivas propias, como veremos a lo largo de esta tesis.

\subsection{Mujeres escritoras. Una forma diferente de entender la literatura}

Las mujeres siempre han estado al lado de la cultura, bien como mecenas, bien como creadoras, aunque sea difícil rastrear su obra en las enciclopedias de la historia del arte y la literatura convencionales porque han desaparecido, se las ha invisibilizado o se han considerado un género menor. En la literatura, las mujeres han visto dificultado su acceso a los medios de creación y a la producción. En los diferentes periodos históricos, pocas mujeres tenían posibilidad de dedicarse a la escritura, únicamente aquellas que pertenecían a una clase social acomodada y, en muchas ocasiones, relacionada con entornos religiosos o de la nobleza, como es el 
caso de Isabel de Villena (1430-1490), Santa Teresa de Jesús (1515-1582) o Sor Juana Inés de la Cruz (1651-1695), por mencionar sólo algunas de las más destacadas.

La primera prohibición que tuvieron que afrontar las mujeres fue el acceso a la lectura. De hecho, algunas sociedades puritanas no permitían, ni tan siquiera, la lectura de la Biblia a las mujeres, y la controversia sobre qué debían o no debían leer las mujeres y si algunos libros podían perjudicar o no la «virtud» de las mujeres en general, y las jóvenes en particular, provocaba encendidas discusiones. El peligro, en realidad, radicaba, como señala Stefan Bollmann (2005 [2006]) en el repaso a la historia de las formas de leer, en que las mujeres que aprendían conquistaban, por un lado, «un espacio de libertad al que sólo ella tiene acceso» (Bollmann, 2005 [2006]: 28) y, por otro lado, un sentimiento de autoestima que las convertía en individuos independientes. Estas mujeres aprendían a pensar y configurar un punto de vista sobre el mundo que no tiene que coincidir con el tradicional, ni con la opinión de los hombres. Supone un primer paso hacia la emancipación de las mujeres de la tutela de los hombres en las sociedades patriarcales (Bollmann, 2005 [2006]).

Los cambios sociales influyen también en el ámbito de las artes, surgiendo nuevas formas de producción artística. En la literatura, el género de la novela (principios del siglo XVIII) supuso un punto de inflexión importante en la construcción del pensamiento, al romper con la alta cultura pasando a participar del entretenimiento 58 .

Ese nuevo género literario, la novela, invade y fagocita al resto de géneros porque nace para ser «devorada» por todas las lectoras y los lectores en muy poco tiempo. Francesca Serra (2011 [2013]) pone como ejemplo del cambio en la forma de lectura la Biblia «con la que aprende a leer Viernes en Robinson Crusoe», que es un relato para leer despacio y de forma vertical. El nuevo género, que tendrá en la imprenta una gran aliada, es más democrático y rápido de consumir. «A posteriori

\footnotetext{
${ }^{58}$ La aparición de la novela surge en un momento de cambio sociocultural que deriva hacia una laicización de la ética y la moral y en la que surgen con fuerza conceptos como felicidad o el placer como un derecho universal (Serra 2011 [2013]).
} 
acabaron diciendo que se había producido una democratización de la cultura, pero, en su momento, la palabra más utilizada fue "prostitución"» (Serra 2011 [2013]: 42). Es decir, en este cambio, las mujeres no salen muy bien paradas. Las mujeres que se dejan seducir por la lectura no estarán muy bien consideradas, incluso se habla de ellas como «manchadas». Sin embargo, el punto de inflexión que se ha producido con la aparición de una nueva clase social, la burguesía, en los siglos XVIII y XIX, cuya fortuna dependía de una actividad económica y no de rentas, hace que la situación de las escritoras vaya cambiando al mismo tiempo que cambian las necesidades de las mujeres en general. De todas formas, en esta ocasión también nos referimos a las mujeres de las clases pudientes, puesto que las mujeres sin recursos no encuentran espacios para reivindicaciones propias, más allá de las reivindicaciones de clase (la participación de las mujeres en las revoluciones burguesas resultó determinante, pero siempre subordinada a la reivindicación social considerada de interés general y que dictaban los varones de las organizaciones políticas y sindicales).

Virginia Woolf (1882-1941), en su análisis sobre cómo las mujeres se relacionan con la literatura (Woolf, 1979 [1981]), define la novela como el género que mejor se ajusta a las mujeres porque se puede retomar con más facilidad que otro tipo de géneros para los que se necesita una mayor «concentración», es decir, una dedicación intensa y casi exclusiva en ello. Las mujeres están sometidas dentro del hogar a la exigencia del cuidado de la casa y las demás personas que viven con ellas, lo que suponen constantes interrupciones en su tarea de escritura. «La narrativa era, como sigue siéndolo, el género más fácil para una mujer. Y tampoco es difícil de saber la razón. La novela es la forma artística menos concentrada. La novela puede ser abandonada y continuada más fácilmente que una obra teatral o un poema» (Woolf, 1975 [1981]: 54) 59.

Woolf insiste en la necesidad de que estas mujeres establezcan un espacio donde trabajar de manera tranquila y, sobre todo, que necesitan ser libres para poder desarrollar su potencial. De esta manera, la escritora británica declara que hay que «matar al ángel de la casa» que pone obstáculos murmurando consignas

\footnotetext{
${ }^{59}$ El ensayo «Las mujeres y la narrativa», al que pertenece este fragmento, apareció en The Forum en marzo de 1929 y se reimprimió en Granite and Rainbow.
} 
del como «Jamás permitas que alguien sospeche que tienes ideas propias» (Woolf, 1979 [1981]: 69 ${ }^{60}$. Es decir, pide que a las mujeres se les den las herramientas para ser libres y poder trabajar, en este caso, en el ámbito de la literatura. En nuestra opinión, Virginia Woolf, que no puede ser considerada propiamente feminista, sí reivindica derechos sociales, legales y culturales en la línea de otras pensadoras como exponemos en este apartado.

En España, escritoras como Pilar Sinués de Marco (1835-1893) utilizan argumentos similares a los de autoras europeas y americanas del siglo XIX. Alda Blanco (1998) reseña que la prohibición de dar educación básica a las mujeres estaba ligada al concepto de mujer del XIX. Según ese concepto, una mujer tiene que tener por atributos la modestia y la castidad, mientras que la escritura se relaciona con la sexualidad en el imaginario cultural, lo que hace que muchas mujeres no se atrevan a dar el paso, aunque tengan esas inquietudes.

En realidad, Sinués pide que estos tabús e ideas preconcebidas se abolan. Sin tener una conciencia feminista la escritora realiza una aproximación a un pensamiento crítico semejante al de otras escritoras de la época en diferentes países, es decir, demanda para las mujeres el derecho a la educación. Esta reivindicación será el primer paso hacia la reclamación de los derechos políticos y sociales para las mujeres más adelante. Blanco (1998) describe el argumentario de estas autoras que conciben la escritura como «vehículo para la educación e instrucción de la mujer» y para la construcción del nuevo tipo de «mujer». Los ensayos de la época formulan una noción sorprendente de la escritura en la cual se tejen la necesidad de la instrucción, la educación, la expresión literaria para la mujer... (Blanco, 1998: 25).

Aunque se pueda reprochar a Sinué que sea una representante de la difusión de la imagen femenina como «ángel del hogar», debemos entender el contexto de carencia de derechos de las mujeres del XIX en España, como señala

${ }^{60}$ El ensayo «Profesiones para la mujer», al que pertenece esta cita, apareció en The Death of the Moth. Se basa en la charla pronunciada en la London National Society for Women's Service, el 21 de enero de 1931. El texto mecanografiado de esta conferencia, de una extensión aproximadamente tres veces superior a la del ensayo, se encuentra (incluyendo párrafos eliminados y expresiones alternativas) en The Pargiters, bajo la dirección de Mitchell A. Leaska, 1978. 
Má Cristina Urruela (2005). La aportación de Sinué, una de las primeras profesionales que se ganaron la vida con sus trabajos, radica en que «escribió explícitamente para las mujeres, y buscó de forma constante el acceso a una educación más amplia para ellas, en un tiempo en que la mayoría de las mujeres españolas no sabían leer ni escribir, y las que sabían, debían por ley obtener el permiso de sus maridos, padres o hermanos para publicar» (Urruela, 2005: 157). Consideramos que estas pensadoras, sin ser feministas y sin romper con una sociedad patriarcal, en la que eran privilegiadas, inician el camino de la emancipación.

En Inglaterra, autoras como Mary Wollstonecraft (1759-1797), un siglo antes, proponía algo similar. Para formar a los hijos y las hijas de la clase burguesa consideraba que había que educar a las mujeres para conseguir fortaleza de espíritu. Sin embargo, la autora británica sí parece establecer una postura transgresora, ya que consideraba que la educación convertiría a las mujeres en «compañeras» de sus maridos. «Para organizar una familia, para educar a los hijos, se requiere de modo especial entendiendo, en un sentido sencillo: fortaleza de cuerpo y alma [...] la razón absolutamente necesaria para que la mujer sea capaz de cumplir todo deber con propiedad, y debe repetir que sensibilidad no es razón» (Wollstonecraft, 1791 [1994]: 194-195).

Mientras, en Estados Unidos, la escritora Elizabeth Cady Stanton (18151902) impulsa junto a Lucrecia Mott la «protesta feminista» del siglo XIX en su país. Perteneciente a una familia acomodada, se casa con Henry Stanton, quien la introduce en el movimiento abolicionista. Asiste a la Convención Mundial contra la esclavitud, junto a otras delegadas de mujeres de Boston y Filadelfia, como Lucrecia Mott, pero tienen que escuchar las ponencias detrás de un biombo por ser mujeres. «Stanton no podría creer que aquellos hombres que habían acudido de todo el mundo para declararse a favor de lo que llamaban "emancipación universal" pudiesen sacrificar con total indiferencia los derechos de una parte de la humanidad -los de la mujer» (Alberola, 2012a: 45). Inmediatamente después, Stanton opta por seguir con su vida de ama de casa, pero, hastiada de la monotonía de esta vida, retoma el contacto con Mott, que había estado trabajando por el movimiento de mujeres, y se unen para redactar la Declaración de Sentimientos 
(1848), donde se recoge la reivindicación de derechos políticos y de educación para las mujeres.

Vemos que, a pesar de las iniciativas anglosajonas, la mayoría de las autoras en España consideran que la educación de las mujeres, y su oficio de escritoras, estarían vinculados a la actividad que desarrollan en el ámbito doméstico privado. Sólo algunas pocas activistas de la época van más allá. Emilia Pardo Bazán (18511921), a la que, desde un punto de vista actual, consideramos una mujer avanzada a su tiempo, era una católica, nacionalista, que atendía a los «códigos sociales», como sustenta Maryellen Bieder (1998: 77):

Al privilegiar su conformismo con la construcción social de lo femenino, Pardo Bazán abre espacio para la dimensión nada convencional de su vida y su obra. Sus relaciones de amistad y, a veces, sexuales, con hombres del mundo literario, como por ejemplo Galdós y Lázaro Galdiano, se desarrollaron en este espacio al margen de la proyección pública de las cualidades normativas de una señora católica de la alta burguesía, hija y madre modelo.

Pardo Bazán, a la que denominan en su época «feminista radical», afirma que «todos los derechos que tiene el hombre, debe tenerlos la mujer, se entiende todos los compatibles con la estructura física» (Pardo Bazán en Bieder, 1998: 77). El discurso feminista que construye es evidente, aunque con algún matiz, obviamente es producto de la época. Se trata de un discurso que extiende a sus ensayos, aunque no resulte tan presente en sus relatos de ficción, que tienen un carácter más social. En nuestro caso, nos interesa su incursión en la novela negra y, en este sentido, su personaje, Ignacio Selva, que desarrollaremos más adelante.

Pardo Bazán acabará rompiendo convencionalismos, se separará de su marido $^{61}$ y decidirá sumergirse en una vida intelectual y vivir de su trabajo literario, lo que ella misma considera una decisión «del todo varonil». Carmen

61 Es interesante comprobar como muchas de las escritoras españolas del siglo XIX que manifiestan opiniones críticas sobre la situación de la mujer siguen el mismo camino. Mantienen una vida más o menos aceptable según los criterios patriarcales de conducta femenina, aunque se separan de sus maridos y ejercen una profesión como escritoras. Es el caso de Carmen de Burgos (1867-1932), María Pilar Sinué o de Emilia Pardo Bazán, tan diferentes respecto a, por ejemplo, la actitud más beligerante de Concepción Arenal (18201893), «feminista temprana que criticó abiertamente el sistema establecido y que fue considerada no sólo impopular, sino también fría, seca y varonil» (Urruela, 2005: 157). 
Bravo-Villasante (1972) cita una carta de la escritora a Benito Pérez Galdós (18431920) donde se observa su conciencia de ruptura con el rol que le ha asignado la sociedad: «esta especie de trasposición del estado de mujer al hombre, es cada día más acentuada en mí. De los dos órdenes de virtudes que se exigen al género humano, elijo las del varón... y en paz» (Bravo-Villasante en Bieder, 1998: 81). Es sorprendente cómo en una época en que la asignación de roles se realiza atendiendo a razones biológicas con el sistema dual de sexos (mujer/varón), Pardo Bazán ya intuya que los roles que se asignan biológicamente presentan una construcción cultural y que se puede decidir a cuál quiere cada persona adscribirse, pero no olvidemos que la escritora gallega puede vivir de alguna forma en los márgenes porque tiene medios económicos suficientes para vivir de la escritura y reivindicar la igualdad con los hombres.

Más próxima en el tiempo, la escritora mexicana Rosario Castellanos (19251974) considera, como las autoras anglosajonas del XIX, que las mujeres escriben de una manera distinta:

[...] se espera de ellas que tengan un estilo propio, una característica inconfundible, en fin, una especie de marca de fábrica. Pero ésta existe. Es ligeramente extraño que no la hayan advertido quienes formulan esta exigencia, porque la marca de fábrica es un defecto, un defecto que, por su constancia, por su invariabilidad, por su persistencia en toda obra salida de manos de mujer, tiene que ser considerado y admitido como estilo, característica y modo distintivo (Castellanos, 1950 [2005]: 208).

Todas estas mujeres suman reivindicaciones hasta que, en el mundo anglosajón, aparecen autoras como Sandra M. Gilbert y Susan Gubar (Las locas del desván), que consideran que «la pluma del poeta es en cierto sentido (incluso más que de forma figurada) un pene» (Gilbert y Gubern, 1979 [1984]: 18). Esto significa que las mujeres escritoras deben empoderarse como autoras. Y precisamente esa es la cuestión. Hasta el siglo XX a las mujeres se les ha impedido tener una voz propia, a pesar de que muchas de ellas lo hayan intentado, algunas como feministas, otras con inquietudes por reivindicar los derechos de las mujeres, pero sin declararse feministas. Hemos comprobado que las escritoras, por decisión 
propia, o porque se las prejuzgaba como poco dotadas escribían sobre temas «propios de mujeres» o se decantaban por géneros menores.

Las mujeres resuelven crímenes de manera diferente a los hombres, como opina Paco Camarasa:

En las obras de mujeres hay muchísima menos sangre y entrañas en el crimen en sí y, en cambio, sus detectives están más atentos a los detalles de la cotidianeidad [...] Usan más la mirada de las armas y los crímenes no son tan sanguinarios, a excepción de los casos que ve la comisaria foral Amaia Salazar de Redondo, pero que se dan en un contexto rural, donde el crimen es más salvaje al ser pueblos, ollas a presión social (Camarasa en Geli, 31 de enero de 2014: en línea).

A pesar de que en la historiografía general del género y en el mundo de la edición del género, las mujeres han sido invisibilizadas, encontramos que existen aportaciones pioneras como las de Ebenezer Gryce, de Anna K. Green (1846-1935), que creó la primera detective; Emilia Pardo Bazán (1851-1921), quien introdujo la primera crítica de la sociedad62; Carolyn Wells (1862-1942), que elaboró la primera antología de narraciones policíacas, y el primer ensayo teórico sobre el género; The Circular Staircase de Mary Roberts Rinehart (1876-1958), la primera novela de suspense; L'affaire Bellamy de Frances Noyes Hart (1890-1943), el primer caso judicial, que se olvidó tras la aparición de Perry Mason (Erle Stanley Gardner, 1889-1970) (López Martínez, 2006), sólo por mencionar algunos ejemplos ${ }^{63}$.

Las autoras asumen las características básicas de los subgéneros (novela enigma, hard-boiled, suspense....) introduciendo elementos que los enriquecen. Los relatos de enigma de las mujeres son claramente realistas, sumergiendo a sus personajes en problemas existenciales. Escritoras como Agatha Christie se

${ }^{62}$ Emilia Pardo Bazán era mujer polifacética. Su compromiso social es importante en su obra, bien a través de su obra naturalista (Pardo Bazán introdujo el naturalismo en España y lo reinterpretó a las condiciones españolas), bien a través de su incursión en la novela negra. La vertiente social de la novela negra la convierte en el medio ideal para exponer sus inquietudes sociales, el resultado es La gota de sangre (1911). Ampliaremos esta idea en el capítulo dos de la presente tesis.

${ }^{63}$ En el artículo de Isabel Santaulàlia i Capdevila (2005b) «Un viaje al reino de la niebla. La novela de detectives en Gran Bretaña» la autora hace un repaso más profundo sobre las escritoras anglosajonas que se forman parte del género negro. 
caracterizan por sus diálogos efectivos, que cumplen una doble función: por una parte caracterizar a los personajes, y por otra desvelar pistas que llevan a la resolución del caso. De hecho la solución al caso viene de la mano de los propios personajes (James, 2009 [2010]).

Son escritoras de su época y sus obras relatan las inquietudes del momento en que viven y desarrollan su actividad literaria (este aspecto lo iremos desarrollando a lo largo de nuestro análisis, con diferentes ejemplos). López Martínez (2006: 27) afirma que las escritoras de novela negra «dinamitan desde el interior» la estructura narrativa del género negro, ya que introducen, incluso cuando siguen la fórmula, temas nuevos como la psicología criminal (motivación) y enlazan elementos cotidianos del ámbito privado con los elementos del ámbito privado de los que dependen.

Esto se produce sobre todo a partir de la novela negra más próxima a nuestros días, sin embargo, reconocemos que las primeras escritoras abren un camino y apuntan en la dirección correcta para hacer de su oficio un acto de rebeldía. López Martínez (2006: 27), en este sentido, continúa su razonamiento:

Rebeldía frente a la falta de cobertura social a la que se enfrentan las víctimas, pero sobre todo las víctimas mujeres. Rebeldía que traduce su mirada, desde los bastidores de la vida, rebeldía que recoger su narración, consciente del proceso de creación, pero sobre todo rebeldía frente al silencio que tratan, con su voz y con su mirada, de disolver para enaltecer, lo que dura una novela, el valor de la justicia moral, el coraje de sus protagonistas y el valor de los propios recovecos de la escritura.

Por nuestra parte consideramos que, efectivamente, las escritoras, especialmente en la época contemporánea, aun utilizando las mismas herramientas y estructuras que los varones, añaden temas e inquietudes específicas, aunque sea de manera implícita. Como señalan las autoras Maureen Reddy y Shelley Godsland, sólo el hecho de que las mujeres escriban es un acto subversivo con el sistema establecido (Reddy y Godsland en Venkataraman, 2010).

Nos parece interesante concluir este apartado señalando que la novela negra goza de muy buena salud en el mundo. Como manifiesta P.D. James (2009 
[2010]) hoy día existe un gran interés por la novela negra, a lo que cabría añadir: esté escrita por mujeres o por hombres. La accesibilidad a las herramientas de edición y distribución de publicaciones mediante diferentes servicios de Internet han, en cierto modo, «democratizado» la publicación de la novelas (sobre todo, por parte de escritoras y escritores no profesionales). Por otro lado, por parte de las grandes empresas, la estrecha relación de sus «estrellas» con el cine y la televisión ha supuesto un escaparate extraordinario para fans del género y simples lectoras y lectores sin interés específico. Todos estos aspectos son importantes para el análisis de cualquier obra literaria, pues como comenta Dora Sales (2012):

[...] lamentablemente, no basta con que alguien escriba y escriba bien, sino que otros elementos del polisistema ${ }^{64}$ son esenciales para que en definitiva esa voz tenga mayor o menor presencia. Existen personas e instituciones (editores, medios de comunicación, premios, etc.) que promueven o impiden la lectura, escritura o reescritura (traducción) de la literatura, y que ejercen como mecanismos reguladores del papel que ocupa la literatura en la sociedad (Sales, 2012: 137).

De este modo, vemos que tan importantes como las escritoras y escritores son las editoras y editores ${ }^{65}$. Cada vez son más las mujeres que toman decisiones en las editoriales, sin olvidar la importancia de las traductoras y traductores que se convierten, en muchas ocasiones, en las «posibilitadoras» y «posibilitadores» para

64 Even-Zohar desarrolló la nación de literatura como un «polisistema», es decir, un «conglomerado de sistemas» diferenciado y dinámico que se caracteriza por oposiciones internas y cambios constantes. Entre las oposiciones está la que se da entre modelos y tipos «primarios» (o innovadores) y «secundarios» (o conservadores), la que se da entre el centro y la periferia, entre estratos canónicos y no canónicos, entre formas más o menos codificadas, entre los diversos géneros, etc. El aspecto dinámico se deriva de las tensiones y conflictos generados por estas oposiciones múltiples de manera que el polisistema en su conjunto, y sus sistemas y subsistemas constituyentes, están en un estado de flujo perpetuo, siempre inestable. Puesto que el polisistema literario tiene su correlato en otros sistemas culturales y está inmerso en las estructuras ideológicas y socioeconómicas de la sociedad, su dinamismo está lejos de ser mecanístico (Hermans en Carbonell i Cortés, 1997: 53).

${ }^{65}$ Las y los profesionales de la edición se encargan de la selección de los textos a publicar, por ello deben de tener una visión global, no sólo del proceso de publicación sino también del contexto en el que se va a comercializar la obra. Así, pueden ser un elemento fundamental en la promoción de un determinado tipo de literatura y unas autoras u otros escritores. A pesar de que el mundo editorial está muy masculinizado, observamos un aumento de editoras que introducen una nueva perspectiva en sus empresas. 
que una obra llegue al público. También en este ámbito las mujeres tienen una gran presencia.

En esta tesis, sin embargo, nos centraremos en las autoras (Alicia Giménez Bartlett y Mercedes Castro) y sus personajes (Petra Delicado, Clara Deza y Teresa Sinde) sin entrar en cómo otros elementos relacionados con el ámbito editorial influyen en estas novelas.

\subsection{Síntesis}

A lo largo del presente capítulo, hemos presentado el origen de la novela negra, situado a mediados del siglo XIX, en concreto en el año 1841 con la publicación de «Los crímenes de la calle Morgue» de Edgar Allan Poe. En esta historia, el autor plantea una interacción con la lectora o lector durante el proceso de resolución, motivo por el cual se considera el inicio del género negro con la forma del subtipo de relato enigma. Son representantes de este subtipo de novela negra, personajes femeninos y masculinos de manera indistinta, Sherlock Holmes o Miss Marple, por ejemplo. También cabe destacar la importancia de los relatos por entregas en el desarrollo y popularización en el primer momento del género. Este subtipo de novela negra, muy exitosa entre el público y aceptada por la crítica, dará paso a un nuevo subgénero procedente de Estados Unidos, la denominada hardboiled. En las hard-boiled, el detective pasa a ser un profesional que se dedica en cuerpo y alma a la investigación, se representa como un personaje duro y violento. Por su parte, el personaje femenino protagonista por excelencia es una femme fatale, un personaje hipersexualizado que manipula al resto de personajes, sobre todo a los hombres, para obtener lo que desea; además, es mostrada con un trasfondo perverso y dañino, sobre todo para el protagonista masculino, que es el único que sabe resistirse a sus intenciones y «manejarla».

Al igual que todos los géneros literarios, la novela negra continúa evolucionando y, como hemos mostrado en el presente capítulo, en los sesenta, pasa a destacar una novela negra que tiene como elemento principal el suspense, 
la historia se centra en la víctima y en todo lo que la rodea. Este progreso viene influido, principalmente, por el cine de Alfred Hitchcock. Este tipo de novela se extiende tanto en Europa como en Estados Unidos.

En la actualidad, la novela negra está muy fragmentada, no podemos hablar de un tipo definido como en los años anteriores, ya que aparecen muchas novelas negras que se arraigan en un espacio geográfico, cultural y social concreto, pero al mismo tiempo comparten características que hacen que el público las acoja con interés. Son novelas como la novela nórdica, que ha abierto un espacio editorial importante, o las periféricas como la novela africana en la que se realiza una crítica a la sociedad corrupta y desigual, y la novela japonesa, determinada por una sociedad tradicional, en sus orígenes, y que suele aunar costumbrismo y crítica social, por poner solo unos ejemplos de un panorama amplio y en continua expansión.

Desde los inicios del género negro hay autoras como Agatha Christie o Pardo Bazán, que se decantan por escribir novelas del mismo, aunque no sea una dedicación exclusiva al género en todos los casos. En un primer momento, no parece que haya diferencia entre las novelas de las escritoras y de los escritores, sin embargo, consideramos que en la contemporaneidad el hecho de que sea una mujer la que escriba el relato supone un elemento significativo, pues supone un posicionamiento explícito o implícito de crítica a la desigualdad y una reivindicación por la igualdad. 



\section{CAPÍTULO 2. \\ LA NOVELA NEGRA EN ESPAÑA}

2.1. Inicios del género negro en España

2.2. Novela negra durante la Dictadura (1939-1975)

2.3. Novela negra durante la Transición (1975-1982)

2.4. La novela negra contemporánea en España

2.5. Aproximación a las novelas negras periféricas en España

2.5.1. Novela negra catalana

2.5.2. Novela negra gallega

2.5.3. Novela negra en euskera

2.6. Síntesis 



\section{CAPÍTULO 2. La novela negra en España}

Mi nombre es Sherlock Holmes y mi negocio es saber lo que otras personas no saben.

Por lo que respecta a la novela negra en el ámbito español, la cuestión reside en determinar si hay una novela negra autóctona o se trata de una adaptación de la novela negra anglosajona y, en menor medida, de la novela negra europea, especialmente la francesa.

\subsection{Inicios del género negro en España}

El origen de la novela negra se sitúa, como hemos señalado anteriormente, en los relatos de Edgar Allan Poe. En España, Fernando Colmeiro (1994) coloca su nacimiento en el momento de la publicación de la novela corta de Pedro Antonio de Alarcón, El clavo (1853). Otras autoras y autores que forman parte de este tímido inicio del género en España son, por ejemplo, Joaquín Belda con ¿Quién disparó? (1909) o Emilia Pardo Bazán (1851-1921). Belda y su novela se han visto involucrados en una polémica entre diferentes autores como Salvador Vázquez de Parga (1981) y Patricia Hart (1987) sobre sus cualidades como novela policiaca: el primero, la considera una novela paródica y popular que únicamente busca la risa; la segunda, considera el texto de Belda como una obra plenamente «española», castiza y picaresca al nivel de la prosa de Quevedo.

Sin embargo, será Emilia Pardo Bazán quien realice una de las incursiones más interesantes en los inicios del género en España, con varias novelas ${ }^{66}$. La escritora, avanzada a su tiempo tanto en el ámbito personal como social, es una viajera y estudiosa incansable, y no sólo se la considera precursora del naturalismo

${ }^{66}$ Misterio (1905), La cita, En coche cama, La cana (1911), La gota de sangre (1911), Belcebú (1913), Selva (un manuscrito incompleto de 168 cuartillas que parece ser la continuación de La gota de sangre). 
en España sino también de la importación de la novela negra, ya que era una gran conocedora de autores como Poe o Conan Doyle. El conocimiento que tiene Pardo Bazán de la novela europea hace que en su incursión en el género utilice las herramientas características de éste (delito, detective capaz, deducción a través de las pruebas y arresto del culpable, lo que siempre restablece el orden inicial). Sin embargo, la autora gallega tiene un estilo propio que se pone de manifiesto en la que se considera la culminación de su paseo por el género detectivesco, La gota de sangre (1911). Los aspectos éticos y estéticos de la escritura de Pardo Bazán enriquecen la fórmula del género policiaco creando a un personaje humano, el detective Selva. Este protagonista se muestra contradictorio y moralmente ambiguo, de hecho deja escapar a la cómplice del asesino, por la que se siente atraído. Se introduce así el conflicto entre el ser individual y la sociedad, construyendo un personaje psicológicamente completo, tan característico de su estilo.

Pardo Bazán hace su incursión en la novela policiaca de una manera crítica, uno de los leitmotiv de la autora en toda su producción, bien sea ficción bien sea ensayo. Su reflexión sobre el relato detectivesco (periodo en el que destaca el relato enigma) la lleva a realizar afirmaciones como que la rigidez de las normas del género hace que las autoras y autores enfaticen la descripción realista de los elementos secundarios quedándose en lo superficial. Para la escritora gallega es reprochable que se detengan en el escenario y accesorio y no se ahonde en el elemento pasional ${ }^{67}$ del acto criminal (Colmeiro: 1994: 112).

El interés de Pardo Bazán por este género, señala Colmeiro (1994), es propiciado por su atracción por lo criminal en todos sus aspectos, tanto sociales como psicológicos. La escritora publicó numerosos cuentos centrados en temas como «el robo, el crimen misterioso, el asesinato rural o las contiendas entre familiares» (Colmeiro, 1994: 106). Las obras de la escritora gallega se caracterizan por su fuerte compromiso social ${ }^{68} \mathrm{y}$ feminista ${ }^{69}$. La autora juzga a la sociedad como

\footnotetext{
${ }^{67}$ Recordemos que históricamente está hablando de relatos impregnados por una moral victoriana, época en la que surge el género, como hemos visto en el primer capítulo.

${ }^{68}$ En lo referente a los cuentos, Colmeiro (1994: 107) menciona títulos como: «Crimen libre», «Pena de muerte», «Un destripador de antaño», «La puñalada», «Causalidad», «La confianza», «En coche-cama», «En el presidio», «Presentido», «El esqueleto» o «Hacia los
} 
la responsable de muchos de estos crímenes, por la carencia de educación y la situación de miseria en la que sobrevivían amplias capas de la población. También reivindica los derechos inalienables de las mujeres, independientemente de su clase, y se «enfurece» por la situación de víctima que, en muchos casos, queda desamparada ante los tribunales, justificando que en caso de que sea la criminal no se la juzgue con el mismo rigor, porque si no tiene los mismos derechos, no debe sufrir con la misma dureza las leyes, elemento que introducirá en sus relatos. A esto añade la escritora gallega que las injusticias se ven amplificadas por un sistema policial, judicial y penitenciario ineficiente, y aboga por una mejora de éste aproximándose a los sistemas europeos.

Colmeiro (1994) expone, a la vista de estas inquietudes, lo siguiente en relación a cómo Pardo Bazán materializa su aproximación al género:
Hemos comprobado cómo Pardo Bazán, partiendo de una revisión crítica a la novela policiaca desde presupuestos éticos y estéticos, se aprovecha de sus convenciones genéricas para explorar la problemática psicológica, moral y social alrededor del crimen, superponiendo una peripecia argumental de intriga sobre un trasfondo social realista que aúna los futuros caminos que el género habrá de tomar (corriente «psicológica», corriente «negra» y corriente de «suspense»). Estas innovaciones que Pardo Bazán incorpora al género policiaco no serían aprovechadas, ni siquiera reconocidas, por otros autores españoles (Colmeiro, 1994: 124-125).

ideales» recogidos en sus Obras Completas editadas por Aguilar en tres volúmenes (fecha de edición de los volúmenes 1 y 2, 1947, volumen 3, 1973).

${ }^{69}$ Cuando calificamos la obra de Pardo Bazán de feminista la contextualizamos en su época (finales del XIX y principios del XX) y teniendo en cuenta que la escritora es católica. No se trata de un feminismo como el actual, aunque los temas que trata, el placer de las mujeres, la situación de las mujeres, entre otros, continúan siendo reivindicaciones de la agenda feminista de hoy en día. Aun así en su obra junto a la vertiente de compromiso social con las clases más desfavorecidas intenta introducir una perspectiva sobre la injusticia que se cierne sobre las mujeres. Repasando algunas de sus obras de manera rápida, ya que no son el objetivo de esta tesis, destacaremos algunos títulos como: Una viaje de novios (1881), en esta primera novela expone el matrimonio como una limitación para las jóvenes; $L a$ tribuna (1883), donde se acerca a las reivindicaciones de la obrera, sin olvidar la problemática de las mujeres trabajadoras; Los pazos de Ulloa (1886), una de sus obras más conocidas; La madre naturaleza (1887), donde además del trasfondo social trata el tema de las relaciones amorosas a través de la relación incestuosa de unos adolescentes; Morriña (1889), que gira en torno a las relaciones entre una mujer, su hijo y la nueva sirvienta llamada Esclavitud; o Insolación (1889), donde narra una relación extramatrimonial. En ella explora el placer de las mujeres, y la obra fue muy cuestionada en su momento al ser considerada indecente. 
Tras esta primera etapa, caracterizada más por la asimilación de las características de la novela negra que se escribe en Europa, llega una época, entre la Guerra Civil y la Transición, en la que el género prácticamente será inexistente.

\subsection{Novela negra durante la Dictadura (1939-1975)}

La novela policiaca que se escribe durante las décadas de los cuarenta y cincuenta, en España, suele caracterizarse por imitar a la novela anglosajona y francesa, por lo que una vez más no podemos hablar de una novela autóctona con características propias. Francisco González Ledesma explica que entre 1940-1975 la censura hace imposible escribir una novela negra autóctona porque una de las características fundamentales es situar la acción en un espacio urbano reconocible y, en la España de la dictadura, eso resultaba imposible, no se podían «tratar en sentido crítico ambientes españoles en los que actuaban policías españoles» (González Ledesma, 1987: en línea). El público tampoco lo hubiera aceptado bien. Recordemos que en aquellos momentos se identifica policía con la Brigada Social ${ }^{70}$, con todo lo que eso podía suponer en el imaginario colectivo sobre la función de la policía. Para el público, en general, «todo lo bueno sucedía entonces fuera de España, y las únicas policías con garantías de origen eran Scotland Yard y el FBI, sobre todo este último» (González Ledesma, 1987: en línea). De esta manera, los escritores ${ }^{71}$ de novela negra de la época, continúa el escritor barcelonés, no describen espacios españoles y menos si tienen que hablar de corrupción. Lo máximo que se atreven a tensar la situación con la censura es introducir alguna frase del tipo: «Ella le insinuó sus encantos». Los autores, para sortear estos obstáculos, firman estas obras con seudónimos anglosajones (generalmente deformaciones de sus nombres (Canalda y Cantero, 2002)), bautizan a los protagonistas con nombres que suenan

\footnotetext{
${ }^{70}$ La Brigada de Investigación Social, conocida popularmente como Brigada Político-Social (1941-1978), era la policía secreta que se encargaba de la persecución y represión de cualquier oposición al régimen franquista.

${ }^{71}$ González Ledesma únicamente menciona a escritores varones. Durante este periodo encontramos a pocas mujeres que se dedique al género negro. Consideramos que en cierto modo se produce al llevar al plano editorial los roles sociales. Así se consideran unos géneros literarios más propios de mujeres y otros de hombres, tanto si nos referimos a autoras y autores como se hablamos de lectoras y lectores.
} 
ingleses y los espacios también son extranjeros. Los más importantes fueron: Víctor Debrigode Duggo, que escribió bajo el seudónimo de Peter Debry; Orlando García, que usaba el alias de Orlando Garr; Rafael Segovia Ramos, quien firmaba como Raf Segram; Luis García Lecha era Louis G. Milk; Miquel Oliveros Tovar se decantó por el sobrenombre de Keith Luger (González Ledesma, 1987: en línea). Colmeiro (1994), por su parte, expone otras razones, como que las obras extranjeras se consideran las originales, la ocultación de la autoría en relación a un subtipo desprestigiado, pero, sobre todo, el hecho de que no resultan creíbles este tipo de tramas en pleno franquismo, además de la, mencionada con anterioridad, desconfianza generalizada hacia la policía y el hecho de que la profesión de detective no era legal entonces. A pesar de lo cual el número de publicaciones populares de este tipo es cuantioso.

La literatura española también tiene su versión económica y de rápido consumo, los bolsilibros o «novelas de a duro» (versión de las dime novels estadounidenses). Suelen ser libros de corta extensión que pueden tratar de diferentes géneros literarios: novelas del oeste (Marcial Lafuente Estefanía, Silver Kane, entre otros), novela romántica (Corín Tellado, la mayor exponente), novela de ciencia ficción, novela negra (Keith Luger, Orlando Garr, etc.), entre otros. Los relatos eran sencillos y se ajustaban a la estructura de la fórmula. Las escritoras y escritores eran profesionales que tenían oficio y desarrollaban una narrativa fluida y eficaz (Canalda y Cantero, 2002). Estas novelas no pretendían convertirse en obras de arte, su objetivo fundamental era el entretenimiento a un precio asequible, y la precariedad era la norma para las autoras y autores que cobraban, en la mayoría de los casos, poco, y a las (y los) que se les exigía un ritmo de producción muy rápido. Estas novelas se vendían en los kioskos o se realizaba un trueque a cambio de una rebaja del precio de la novela (una lectora o lector dejaba su ejemplar y cogía otro a cambio de una pequeña cuota). Se trata de un formato popular para una literatura popular. 
La novela negra, en ese momento, se desarrolla de forma paralela al resto de novelas de otros géneros, introduciendo elementos de vanguardia que la convierten en un experimento innovador, un ejemplo sería El inocente (1953) de Mario Lacruz. Vemos que esta novela se aleja del whodunit ${ }^{72}$ de la novela policiaca clásica con la introducción de elementos novedosos como la música dentro del relato. Lacruz narra la huida de Virgilio Delise, acusado de haber asesinado a su padrastro. Hace hincapié en el ambiente opresivo que rodea al protagonista y en el que la incompetencia de los representantes de la ley provoca indefensión en el protagonista. El interés del autor reside en:

[...] mostrar como la represión crea su objeto y la necesidad de autolegitimación del régimen (representado por la institución fundamental, la policía) se antepone a la verdad. Lacruz no describe simplemente la dicotomía ente el individuo honesto y la corrupción institucional, como hace la novela negra [...] En la España de Franco, sin embargo, el derecho civil y la verdad demostrable han dejado de ser valores sociales, y el individuo no puede apelar a ellos. Por eso, un autor sensible a la incompatibilidad del género con el sistema social de la dictadura adopta preferentemente el punto de vista del individuo cazado por el sistema (Resina, 1997: 47).

El franquismo no parece, a priori, el mejor contexto para que se afiance la novela negra. En un primer momento el retraso social, económico y cultural sufrido durante la posguerra dificulta las condiciones de modernización en las que surge el género en otros países. Por otro lado, la censura impide el crecimiento de un género caracterizado por su apego a la realidad y la crítica social.

En este punto, se hace necesario introducir una precisión temporal que permitirá entender mejor la evolución del género negro en esta época. En los años sesenta se observan, en España, las primeras señales de cambio, sobre todo, en el ámbito económico y social. Hagamos un pequeño inciso para entender qué está sucediendo en el ámbito socioeconómico y cultural. A grandes rasgos la dictadura

\footnotetext{
${ }^{72}$ Este término es la abreviatura de la pregunta Who has done it? (Who's done it?), en castellano «¿Quién lo hizo?», y hace referencia a un subgénero de novela negra centrada en el juego de descubrir al asesino, la novela enigma.
} 
franquista se puede dividir en dos periodos: la primera etapa ${ }^{73}$, que va entre 1939 y 1959, se caracteriza por un férreo control social y político. Son los años de la autarquía económica; la segunda etapa se inicia con el Plan de Estabilización que pretende sacar a España de la autarquía anterior, comprende los años que van desde 1959 hasta 1975, y se caracteriza por una progresiva apertura económica, son los años del desarrollismo en los que surge una incipiente clase media además de producirse mejoras en la educación. Esta reforma económica no lleva aparejada una mayor libertad política, continúa la censura. En este momento, se producen movimientos en el ámbito cultural que llegan a los gustos literarios del público, que se interesa por los nuevos géneros que vienen del extranjero.

En este contexto Manuel Pedrolo ${ }^{74}$ (1918-1990) comienza a escribir una novela negra más atrevida, igual que Lacruz, adopta el punto de vista del perseguido. Patricia Hart (1987) considera que este autor, que desarrolla su obra en catalán, es fundamental en el establecimiento y desarrollo de lo que será la novela negra catalana y española. Pedrolo opta por una novela negra más próxima al hard-boiled. Su primera novela será Es vessa una sang fàcil (1952).

El éxito de Pedrolo en parte es debido al traductor de su obra, Jaume Fuster (Resina, 1997) que toma la obra del escritor catalán, situada en Barcelona, e introduce elementos novedosos, y la «aclimata» a un tipo de novela negra más convencional que se entiende mejor en España.

Por otra parte, encontramos a Francisco García Pavón (1919-1989) que, según Colmeiro (1994: 154), ennobleció «el género ante el público culto» ${ }^{75}$. Para

\footnotetext{
${ }^{73}$ Estos amplios periodos tienen subetapas que no detallaremos, por alejarse de los objetivos de la presente tesis.

${ }^{74}$ Es vessa una sang fácil (1954), L'inspector arriba tard (1960), Joc brut (1965) y Mossegarse la cua (1967), entre otras.

${ }^{75}$ García Pavón creará al detective Manuel González, Plinio. Se trata de un personaje autóctono que no sigue la tradición anglosajona. Es un personaje complejo y humano que sirve como modelo para futuros protagonistas del género. El Quaque (1953); Los carros vacíos (1965); Los jamones (1965); «El carnaval» (1968) y «El charco de sangres» (1968) dentro de Historias de Plinio; El reinado de Witiza (1968); Las Hermanas Coloradas (1969); Nuevas historias de Plinio (1970) donde se recogen otras publicadas («Los carros vacíos»,
} 
conseguirlo crea a Plinio, un detective que trata problemas propiamente españoles. Además, opta por situarlo en un entorno rural, lo que tiñe la novela de elementos costumbristas que chocan con el avance tecnológico que se está produciendo. Son novelas que se enmarcan dentro del subtipo enigma. En este caso, la novela policiaca es una excusa para dar a conocer diferentes historias que conforman el verdadero interés del autor.

Con esto comprobamos que en España conviven diferentes subtipos de novela negra al mismo tiempo intentando sortear la censura. Pedrolo, como Lacruz, denuncia la violencia del sistema en el que la justicia no vale, mientras García Pavón opta por un género negro basado en un personaje sencillo que desvela el enigma que supone el crimen.

Así pues, observamos que será en el tardofranquismo y durante el periodo del desarrollismo cuando se den las condiciones para que se introduzcan las bases del género negro que eclosionará durante la Transición, una vez desaparezca la censura. La verdad sobre el caso Savolta ${ }^{76}$ (Eduardo Mendoza77, 1975) se considera iniciadora del boom del género. Esta novela no es estrictamente una novela negra. Mendoza mezcla diferentes géneros, voces y una fuerte carga de acción. Recupera la temática criminal y la marginalidad como elementos de la narración a los que

«El Quaque», «Los jamones») e inéditas como «El huésped de la habitación número cinco», «El caso de la habitación soñada», «Echaron la tarde a muertos», «Las desilusiones de Plinio» y «Muerte y blancura de Baudelio Perona Cepeda»; Una semana de lluvia (1971); Vendimiario de Plinio (1972); Voces en Ruidera (1973); El último sábado (1974) incluye diez relatos inéditos, «El último sábado, «Las fresas del Café Gijón», «Los sueños del hijo de Pito Solo», «Fecha exacta de la muerte de Polonio Torrijas», «Sospechas anulares de Plinio», «La esquela mortuorio», «Detalles sobre el suicidio de Arnaldo Panizo», «Un crimen verdaderamente perfecto», «Una tarde sin faena de Plinio y don Lotario», «La bella comiente»; Otra vez domingo (1978); El caso mudo y otras historias de Plinio (1980) que contiene un único relato inédito, «El caso mudo», junto con otros relatos publicados anteriormente; El hospital de los domingos (1981); Cuentos de amor... vagamente (1985) contiene dos relatos inéditos: «Pan caliente y vino fuerte, mi muerte» $\mathrm{y}$ «El roncador».

76 Esta novela fue galardonada con el Premio de la Crítica en 1976, lo que ayuda a enaltecer el género.

77 Destacaremos dos novelas más de género negro, en esta ocasión, en un tono completamente diferente, de este autor: El misterio de la cripta embrujada (1979) y El laberinto de las aceitunas (1982). La amplia obra de Mendoza abarca casi todos los géneros narrativos, lo que le ha valido el Premio Cervantes en 2016. 
añade una estructura de intriga. Sin embargo, no deja de ser curioso que utilice un caso de los años veinte y no un episodio contemporáneo a su redacción.

Hemos consignado la incipiente novela negra de los siglos XIX y XX, y cómo tras la Guerra Civil se desarrolla una novela próxima a la vanguardia y bastante alejada a la novela policiaca, que en las décadas de los sesenta y setenta construye los cimientos de los que será la novela negra desde la Transición hasta la actualidad, teniendo como una de las figuras más reconocidas a Manuel Vázquez Montalbán (1939-2003). Es interesante la reflexión que se plantea en la compilación de Paul Aubert (2001), que hace un recorrido por la novela negra de los siglos XIX y XX y coloca la prehistoria de la novela policiaca en España precisamente en el periodo franquista.

\subsection{Novela negra durante la Transición (1975-1982)}

La novela negra está muy relacionada con la modernidad, y el retraso socioeconómico-cultural de España a causa de la dictadura franquista define el desarrollo de este género de manera determinante (Lissourgues, 1992, Colmeiro, 1994, Tyras, 2001, Balibrea, 2002). Hemos señalado con anterioridad que será en los años sesenta, con el desarrollismo, cuando surjan los fundamentos de la novela policiaca española y que con el fin de la dictadura cuando se producirá un estallido del género. Esto se produce al mismo tiempo que en el ámbito político España se sitúa a nivel de los estándares europeos, es decir, España ingresa en la modernidad de pleno derecho (estructura del estado, ámbitos jurídico, económico, social, etc.) justo en el momento en el que la modernidad deja de ser el marco dominante de la realidad. Así pues, se ve obligada a adaptarse a una postmodernidad que «considera los metarrelatos explicativos, desacredita los antagonismos, anula toda relación entre la política, el delito, y sepulta las diferencias bajo la primacía de consenso» (Blanco Aguinaga, en Tyras, 2002: 101). Una postmodernidad en la que la incertidumbre lo invade todo: 
[...] -eclecticismo, incoherencia, pluralismo, ambigüedad, etc.- no son sino un reflejo de la sociedad en la que nos ha tocado vivir: el fin de los absolutos y de la utopía y un cierto malestar ante la falta de modelos a seguir; vivir siempre en la incertidumbre, ansiando un orden, un origen, un centro, pero habiendo perdido la esperanza de recuperarlos (Vidal, 1989: 15).

Más adelante, veremos que las protagonistas de la novela negra se impregnan de estos valores y muestran contradicciones en diferentes aspectos de su vida. España, en este momento, sufre una gran convulsión social, no únicamente por el cambio político sino por los cambios estructurales que se llevan a cabo en todos los ámbitos: reconversiones industriales que dejan en paro a miles de trabajadores, creciente violencia, consumo de drogas, paro juvenil, mercantilización de la vida, etc. Todo esto en un momento en el que la ciudad cobra un mayor protagonismo y relega el ámbito rural. La novela negra es una novela eminentemente urbana, de ahí que sirva de herramienta a toda una generación como medio de descripción y denuncia de la realidad. El realismo es una de las características de la novela negra española, y por otro lado los escritores de la época reinterpretan en clave de los sesenta y setenta la novela de Hammett o Chandler (Lissorgues, 1992).

Manuel Vázquez Montalbán (1939-2003) (Imagen, 6), tiene una ingente producción literaria tanto en el campo de la ficción como en el ensayístico. Sus ensayos abarcan diversos campos: político, sociológico, histórico, culinario y literario, en el que destacan sus reflexiones y análisis

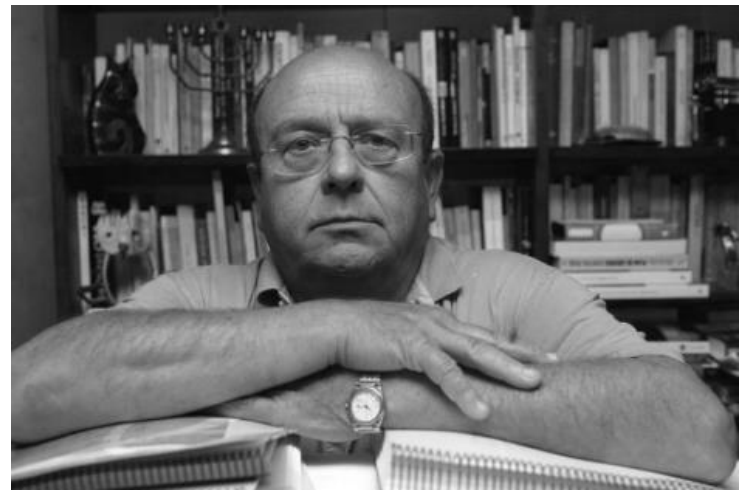
sobre las características de la novela Imagen 6. Manuel Vázquez Montalbán negra. Una de las cuestiones que plantea es precisamente que la novela negra debe representar la sociedad de su momento, como si paseara un espejo por el camino al que sumar una visión crítica. Vázquez Montalbán considera fundamental introducir en estas historias las consecuencias que han tenido los cambios 
económicos que se iniciaron en la última etapa del franquismo. Tatuaje (1974) inaugura la saga del detective de Pepe Carvalho, un personaje complejo y lleno de contradicciones. George Tyras (2001) lo define como «[...] un gastrónomo exigente y amante positivo, ex agente de la CIA y antiguo militante comunista, letrado distanciado y sociólogo desengañado, encamina el mundo desde una postura no sólo escéptica sino aséptica. Y se rodea de una familia atípica compuesta de algunas muestras de aquellas figuras que la colectividad relega a sus márgenes» (Tyras, 2001: 251). Se trata de un personaje que no encaja con el típico detective de novela negra, pero sí se ajusta a la realidad socioeconómica-política que había vivido España, pero también que está viviendo en ese momento, así como las esperanzas en un futuro democrático. Es decir, Vázquez Montalbán construye su crítica social desde la que nos presenta al protagonista de la saga y lo caracteriza desde ahí, planteando una crítica a la Transición en la que está entrando España.

En cierto modo, la novela negra consigue convertirse en un diario de la situación social: «El universo de héroes y antihéroes, de acontecimientos heroicos y antiheroicos, de marcos cotidianos, de miedos urbanos y de bajas pasiones que se ofrece en estas novelas coincide en todos sus aspectos con la lectura diaria de la prensa» (Andreu Martín en Tyras, 2001). De hecho, muchos de los escritores y escritoras que se acercan a la novela negra son periodistas que llevan un paso más allá la función de crítica social con la que nace el género, como Francisco González Ledesma (1927-2015), Eduardo Mendoza (1943- ) o Juan Madrid (1947- ), entre otros.

En este sentido, Colmeiro (1994) recoge las diferentes formas de ver la novela negra de estos autores y las divide en tres grupos: el primero estaría formado por los autores que inician un acercamiento al género, Manuel Vázquez Montalbán o Eduardo Mendoza, entre otros. Son autores que mezclan géneros y que están localizados en las coordenadas de la posmodernidad. A estos pioneros les sigue un grupo representado por Andreu Martín y Juan Madrid, autores que siguen la fórmula del género negro, pero la adaptan a la realidad española. El último grupo estaría representado por Juan Benet o Juan Marsé.

Son comunes a todos estos autores los espacios urbanos y la corrupción, enfatizando la denuncia de la violencia que ejerce el poder. Será ya en democracia 
cuando las mujeres se conviertan en un elemento fundamental del género policiaco. Las editoriales comienzan a introducir voces minorizadas hasta ese momento. Uno de los primeros ejemplos es Picadura mortal, de Lourdes Ortiz (1979), una novela que no se puede catalogar de feminista, pero que pone en solfa la necesidad de denunciar las injusticias y «cuya detective no parece funcionar según ninguna norma hasta ahora establecida en la ficción», este aspecto lo analizaremos en el siguiente capítulo.

\subsection{La novela negra contemporánea en España}

La mayoría de los autores de novela negra que desarrollan su actividad en la etapa de la Transición, y que hemos visto en el anterior epígrafe, han continuado con ella hasta el presente. Durante los años ochenta se produjo una expansión de la publicación de novela negra, sin embargo una parte de la crítica considera que se produce un estancamiento, no se introducen novedades significativas y las editoriales prefieren ir sobre seguro y publicar un tipo de novela que la lectora y el lector decodifican fácilmente. Se trata de una producción literaria destinada al consumo. Andreu Martín (1991) opina al respecto:

El «boom» de la novela negra fue coherente en un momento de euforia y liberación, como fue el de la transición. Pero ahora vivimos una época en que se ha vuelto al elitismo cultural. Leer cosas lo más difíciles posible es hacer actos culturales sublimes. Pero en un país serio tiene que haber lectores para todos los géneros. Y el lector que se mueve por modas merece poco respeto (Martín en Piñol, 1991: 34).

Ya en la década de los noventa Xavier Moret (1991), con motivo de la celebración de la Semana Negra de Gijón, analiza la situación de los autores del género negro en España y señala que las editoriales pretenden estimular la publicación de estas novelas: «Dado que los clásicos ya los han publicado todos, 
nuestro objetivo es publicar nueva novela negra [colección Círculo Hueco ${ }^{78}$ ] que por calidad vaya más allá del género» (Agut en Moret, 21 de julio de 1991: en línea). También sobre calidad habla el editor de la colección Grandes Detectives ${ }^{79}$ : «Si nos hemos lanzado a esta aventura, después de unos años bajos para la novela negra, es porque creemos que la fórmula de una colección de escritores vivos de calidad y con protagonista fijo puede tener posibilidades» (Capdevila en Moret, 21 de julio de 1991: en línea).

Sin embargo, los autores que menciona Xavier Moret (1991) en su artículo son escritores que estaban en el oficio de la escritura desde la Transición (o antes) como Madrid, Mendoza, Montalbán... A estos se suman algunos nombres extranjeros (como se observa en los autores que componen las colecciones Círculo Hueco o Grandes Detectives). Respecto a los autores españoles citados que se pueden considerar «nuevos escritores» poco se acercan al género negro y no se dedicaban a la creación de novela negra en exclusividad, como Arturo Pérez Reverte (1951- ), quien crea un híbrido entre los géneros negro y de aventuras. Algunas de sus novelas que tuvieron más éxito: El maestro de esgrima (1988), La tabla de Flandes (1990) y El club Dumas (1993). Antonio Muñoz Molina (1956- ) había explorado el género negro en los ochenta, pero será en la década de los noventa cuando encontramos sus aportaciones más interesantes: Los misterios de Madrid, que se publicó por entregas entre el 11 de agosto y el 7 de septiembre de 1992 en El País. Posteriormente publica Plenilunio (1997), la novela que mejor ajusta al género negro. La obra de Muñoz Molina combina temas de actualidad con temas del pasado planteando cómo superar el resentimiento, la ira, el miedo... que provocan. También basculará hacia un planteamiento humorístico de la novela negra.

Tras estos escritores aparece la Generación X, en cuyas obras, según Toni Dorca (1997: 320-321):

${ }^{78}$ Rubein Fonseca (1925- ), Brasil; Marc Behm (1925-2997), Estados Unidos; Derek Raymond (1931-1994), Reino Unido; Daniel Chavarría (1933- ), Uruguay; Jerome Charyn (1937- ), Estados Unidos; Justo Vasco (1943-2006), Cuba.

${ }^{79}$ Michael Collins (1890-1972), Irlanda; H.R. F. Keating (1926-2011), Reino Unido; William MacIlvnney (1936-2015), Reino Unido. 
Las características formales de la nueva novela española pueden cifrarse en una predilección de la primera persona... que guarda semejanzas con la estructura de la picaresca, aun cuando la linealidad se haya visto desplazada por el desorden en la exposición y el uso del frecuencia repetitiva. Se recurre asimismo al modelo policiaco en la confección de la trama, que suelen dejarse sin resolver en consonancia con lo que la posmodernidad llama la liquidación del centro de autoridad del relato.

Las autoras y autores de esta generación no se decantan mayoritariamente por la novela negra si bien presentan algunas características comunes como los ambientes urbanos de los bajos fondos donde el delito (crimen) forma parte de la vida cotidiana. José Ángel Mañas (1972- ) autor de la Tetralogía de Historias de Kronen $^{80}$, es considerado uno de los mejores exponentes de este grupo. Más recientemente Mañas ha optado por una novela negra más tradicional protagonizada por la pareja de policías Pacheco y Duarte ${ }^{81}$ : Caso Karen (2005) y Sospecha (2010).

Esta etapa en la que autoras y autores consagrados y noveles conviven es seguida por un nuevo fenómeno en este desarrollo de la novela negra española: la aparición de las primeras sagas como tales, de la mano de Alicia Giménez Bartlett (1951- ) y Lorenzo Silva (1966- ), que presentan elementos comunes en ambas series. Profundizaremos en las características de sus obras en el siguiente capítulo.

Así pues, vemos que un periodo especialmente crítico nos encontramos ante un momento heterogéneo mediado por intereses editoriales que prefieren una novela mainstream. George Tyras (2002) señala: «El cuadro no existe sino porque se empeña un crítico en sacar una foto panorámica, cuando quizá la única actitud crítica que valga en la actualidad literaria sea la del acercamiento individual, ya no al género sino a las obras concretas» (Tyras, 2002: 98).

\footnotetext{
${ }^{80}$ Historias de Kronen (1994), Mensaka (1995), Soy un escritor frustrado (1996), Ciudad rayada (1998).

81 «Pacheco y Duarte, dos policías con personalidades antagónicas, uno extrovertido y simpático, mujeriego y putero empedernido, con una tramposa vida familiar, y el otro un homosexual con una personalidad atormentada, siempre en el filo de la navaja, entre los que, en el curso de la acción» (Mañas, s.f.).
} 
Este éxito del género negro español viene de la mano del boom de la novela negra nórdica en España, que comparte algunas de las características como hemos señalado en el primer capítulo. Uno de los aspectos más interesantes es la serialidad, que sin ser nuevo sí responde a las nuevas necesidades editoriales y al gusto de las lectoras y lectores ${ }^{82}$. En este sentido, Balló y López (2005: 37) hablan del «espacio estable»: «un centro de operaciones en el que el detective pensador recopila los hechos, extrae conclusiones y explora salidas de futuro» y que resulta fundamental para que el público al que va dirigido pueda decodificar la historia rápidamente. En el caso de Petra Delicado y Fermín Garzón se encuentran en el despacho de Petra en la comisaría, en la Jarra de Oro, en la casa de la inspectora... para trabajar y discutir aspectos de los diferentes casos. Teresa Sinde intenta recopilar las ideas en su casa, especialmente en el horno antiguo.

El ejemplo nórdico consideramos que refuerza la aparición de nuevas autoras y autores que se convierten en fenómeno editorial y contribuye a la amplificación del fenómeno de la novela negra en España (aunque no exclusivamente). De hecho, tras una pequeña crisis en el cambio de siglo, en el año 2012 se produjo una recuperación y las publicaciones de novela negra superaron otros géneros, también populares, como el histórico. Muchas de las novelas, calificadas por las editoriales como género negro, incluyen, además, un poco de novela histórica, otro poco de amor y otro poco de suspense. Esta mezcla, fusión de géneros, la encontramos en la novela nórdica, pero también en los títulos contemporáneos de la novela negra española, como la Trilogía del Baztán (20132014) ${ }^{83}$ de Dolores Redondo o la Trilogía de la Ciudad Blanca (2016- ) ${ }^{84}$ de Eva García Sáez de Urturi, en los que además observamos episodios de lo que en Latinoamérica se denomina realismo mágico, con la introducción de relaciones con un mundo telúrico espiritual, sólo por mencionar dos ejemplos. También plantean nuevas formas de relación de las y los detectives protagonistas. Dolores Redondo

82 Balló y Pérez (2005: 18) definen como «una ficción infinita de sucesos intermedios» a la «ficción serial», aplicada al medio audiovisual, pero también se puede extender el término a la literatura. Consideramos que esta es una de las características de la novela negra contemporánea tanto en el ámbito internacional como en España.

83 El guardián invisible (2013a), Legado de los huesos (2013b), Ofrenda a la tormenta (2014).

${ }^{84}$ El silencio de la ciudad blanca (2016), Los ritos del agua (2017), la tercera entrega está pendiente de publicación. 
(2013a, 2013b, 2014) es uno de los mejores ejemplos. Los autores varones también se suman a esta tendencia, por ejemplo, Carlos Bassas (1974- ) es el creador de la serie de Herodoto Corominas. Bassas sitúa las relaciones paterno filiales como uno de los elementos fundamentales de su novela Mal trago (2016). Relaciones que cubren varias generaciones: por un lado, Corominas y su padre, por otro lado, Vázquez, su ayudante, con su hija.

Uno de los fenómenos de la contemporaneidad que nos resultan más interesantes es cómo las nuevas tecnologías permiten que las aficionadas y aficionados a la escritura puedan acceder a publicar sus relatos con cierta facilidad, bien mediante autopublicación, bien a través de pequeñas editoriales que están proliferando los últimos años ${ }^{85}$. Uno de los ejemplos más significativos es $E l$ bolígrafo de gel verde (2011), autoeditado por el escritor Eloy Moreno, que debido al movimiento en las redes y el boca a boca vendió ejemplares suficientes para llamar la atención de la editorial Espasa, que lo reeditó ese mismo año.

La novela negra está de moda y uno de los factores que lo demuestra es la proliferación de los festivales sobre el género que han surgido en los últimos años. Generalmente son «semanas negras» cuyas actividades giran en torno a la literatura o el cine negro, además de otras actividades culturales y artísticas relacionadas con el género negro. Repasemos brevemente los más destacados:

- Getafe Negro (desde 2008) es un festival comisariado por Lorenzo Silva y dirigido por David Barba. Página oficial (2016): http://getafenegro.com/2016/gn/.

- Castellón Negro/ Castelló Negre (2010) está promovido por escritoras y escritores, cineastas y artistas plásticos. Sus actividades (exposiciones, conferencias, ciclos cinematográficos, etc.) se realizan en toda la provincia de Castellón con el apoyo de diferentes entidades e instituciones

\footnotetext{
${ }^{85}$ La autoedición se puede realizar de diversas maneras: gestionando el proceso completo personalmente que incluye la impresión y distribución; mediante plataformas que ayudan a la maquetación y distribución del producto como obra propia, bubok o incluso amazon.
} 
(ayuntamientos, Universitat Jaume I, entre otras). Página oficial (2017): http://www.castellonegre.es/.

- Aragón Negro (2014), promovido por el escritor Juan Bolea (1959- ), despliega su radio de acción a las tres provincias de la comunidad autónoma de Aragón. También es un festival multidisciplinar, que incluye una sección gastronómica. Página oficial (2017): http://www.aragonegro.es/.

- Collbató Negre (2014) es un festival que se celebra en la comarca del Baix Maestrat. A las actividades literarias añade una ruta de tapas. Página oficial (2015): https://collbatonegre.wordpress.com/.

- Granada Noir (2015), dirigido por Gustavo Gómez y Jesús Lens, es un festival multidisciplinar que tiene como hilo conductor de sus actividades el género negro. Página oficial (2016): http://granadanoir.com/.

- Pamplona Negra (2015) se celebra en el Palacio de Congresos de Baluarte (Pamplona). Página oficial de Facebook (2017): https://www.facebook.com/pamplonanegra/.

Con todo, los dos festivales de temática negra más destacados, por antigüedad y prestigio, son: Barcelona Negra (BCNegra, desde 2005) y la Semana Negra de Gijón (desde 1988).

- Barcelona Negra (BcNegra), promovida por Paco Camarasa, dueño de la librería Negra y Criminal, nace como homenaje a Manuel Vázquez Montalbán. Página oficial (2017): http://lameva.barcelona.cat/bcnegra/ca.

- Semana Negra de Gijón, promovida por Paco Ignacio Taibo II (1949-) y organizada por la Asociación Cultural Semana Negra desde 2013, también es multidisciplinar, con exposiciones de fotografía, artes escénicas, etc. Página oficial (2016): http://www.semananegra.org/.

Durante los últimos años se han producido algunas polémicas con estos festivales por la escasa representación y visibilidad de las mujeres. La representación de escritoras en estos festivales es todavía deficitaria. La última polémica sobre el tema surgió en la Semana Negra de Gijón en 2016, cuando no fue elegida ninguna mujer finalista al premio Dashiel Hammett. De hecho, en los 29 años en los que se celebra el certamen, sólo lo ha ganado una mujer, Cristina 
Fallarás (1968- ), en el año 2010. Rosa Ribas, finalista con mención especial en 2015, considera que

La polémica me parece necesaria. Algunos se sorprenden de que haya estallado de esta manera y argumentan que otros años también hubo pocas obras escritas por mujeres entre las candidatas a los premios. Pero es que la rotundidad del cero de este año ha hecho estallar un malestar que venía incubándose desde hacía tiempo. No hacia la Semana Negra en concreto, sino en el mundo literario y, particularmente en el mundo de la literatura de género negro (Ribas en Galindo, 2016: en línea).

Fallarás, en la misma línea, expone:

Claro que hay mujeres que han escrito libros que merecen estar ahí, pero tiene que haber voluntad de leerlas. Hay un micromundo macho que no está interesado. Cuando gané el Hammett fue extraordinario: no sólo fui el único sino que además era con un libro sobre la maternidad. La mujer se enfrenta la novela negra (sic) de una manera menos heterodoxa y eso en un mundo cerrado no interesa. El lector se está alejando de eso. A la mayoría de los que están nominados les gustaría vender la décima parte de lo que venden Dolores Redondo o Fred Vargas. Es una cuestión del petit comité de los frikis de la novela negra, que como los frikis de todo, son ultraortodoxos (Fallarás en Galindo, 2016: en línea).

Aleix Ravelo (en Galindo, 2016) considera que esto emana de la esencia masculina y violenta de la novela negra, lo que la coloca en una situación privilegiada para realizar una denuncia del patriarcado. Pero esta situación no es única de este género o de estos festivales literarios sino que es un mal endémico en el mundo empresarial, de ahí que cualquier iniciativa que visibilice a las autoras resulta positiva. Una de ellas queda referida a otros premios literarios que otorgan empresas editoriales e instituciones públicas.

A pesar de esta polémica, en 2016 todos los festivales de novela negra se adhirieron a un manifiesto, escrito por el escritor Lorenzo Silva, contra la violencia machista, que reproducimos a continuación: 


\section{MANIFIESTO DE LOS FESTIVALES DE NOVELA NEGRA CONTRA LA VIOLENCIA DE GÉNERO}

Escribió Walter Benjamin que la construcción histórica se consagra a la memoria de los que no tienen nombre. Parafraseándole, cabe decir que el género negro, en todas sus formas y modalidades, tiene un asunto primordial: atestiguar el dolor de quienes sufren el crimen, exponerlo y ahondar en su conocimiento.

El verdadero centro de una historia criminal es siempre la víctima. Como lectores, cultivadores y difusores del género negro, los abajo firmantes reivindicamos el papel central que corresponde en nuestra sociedad a las mujeres que todavía hoy, entre nosotros, sufren demasiado a menudo violencia por su condición de tales. Mujeres de todas las edades, incluidas ancianas y niñas, de cuya integridad y dignidad disponen sin derecho ni conciencia hombres de todas las edades también.

Reclamamos el protagonismo para ellas y, con él, la protección que merecen por ser la parte más débil de un conflicto, ya sea de índole personal o familiar o derivado de una injusticia social o colectiva, y siempre, en último término, víctimas de la desigualdad entre sexos de la que la violencia contra las mujeres es la más cruel expresión. Hablamos de las mujeres que sufren violencia a manos de sus parejas o ex parejas, 57 de ellas muertas en 2015; pero también de las que por culpa de esa desigualdad, social y de sexo, y de la desidia de quienes deberían protegerlas, se ven expuestas a la trata, la explotación y todas las formas insoportables de violencia a ellas asociadas, de cuyas muertes ni siquiera se lleva la cuenta, por no haber una reacción institucional proporcionada a la gravedad del crimen.

Proclamamos la necesidad de una protección efectiva, que no se quede en normas, formulismos o declaraciones bienintencionadas; que no supla con alardes legales la insuficiencia de medios policiales, materiales o de asistencia, cuando no faltan policías, ni recursos, para atender necesidades menos perentorias.

Por alguna razón casual, o quizá no lo sea tanto, todos los que esto firmamos somos hombres. No arremetemos contra nuestro propio sexo, no participamos de ninguna generalización andrófoba ni pedimos un encarnizamiento contra 
nosotros mismos. Sólo reclamamos amparo eficaz para ellas, y que cese la vergüenza que para todos representan los hombres que no han aprendido a respetarlas, a los que señalamos, hoy y siempre, con nuestro rechazo más firme y profundo.

El ámbito académico tampoco es ajeno a este interés por el género negro, así que se realizan investigaciones y congresos en torno a éste. El congreso más longevo es el Congreso de Novela y Cine Negro de la Universidad de Salamanca que organiza Alex Martín Escribà y Javier Sánchez Zapatero desde 2005. La decimotercera edición se celebró en mayo de 2017. Página web oficial: http://www.congresonegro.com.

Los premios literarios son otro elemento interesante, pues se presentan como un instrumento de marketing de la industria editorial para dar publicidad (visibilidad) a sus autoras y autores. Sin embargo, a nuestro juicio, apuntan también a una línea editorial, aunque esté dentro de la literatura mainstream. Así, la coincidencia que se da en ocasiones en las que la ganadora o ganador y la o el finalista son de diferente sexo es una declaración de apoyo a una cierta igualdad. Obviamente, estamos hablando, en la mayoría de los casos, de empresas, y esta declaración de intenciones tiene un objetivo último: vender más libros al construir identidades con las que identificarse tanto lectoras como lectores. Un ejemplo claro puede ser el Premio Planeta 2016, cuya ganadora ha sido Dolores Redondo (1969- ) ${ }^{86}$ por la novela Todo esto te daré. La escritora vasca saltó al panorama literario con la Trilogía del Batzán. En esta ocasión Redondo sitúa la acción en Galicia, pero continúa manteniendo algunos de los temas que destacan en sus novelas anteriores: los secretos de familia y cómo influyen en la vida de los individuos. En la trilogía, uno de los personajes corales era homosexual, tema que se toca tangencialmente a través del ayudante de la protagonista, Jonan Etxaide, en este caso, el protagonista es abiertamente homosexual y el crimen que investiga es

${ }^{86}$ El finalista fue Marco Chicot (2016), con El asesinato de Sócrates, que presentó una novela de intriga y misterio ambientada en una época histórica (Grecia de Pericles, 435 a.C. -429 a.C.). 
el de su marido. Así vemos que Planeta apuesta por una novela en la que se incluyen dos colectivos minorizados que hoy día continúan reivindicando el reconocimiento de sus identidades. Estas novelas contribuyen a visibilizar la diferencia como algo cotidiano y en las que conviven en la búsqueda de sociedades más justas para todas y todos (independientemente de su sexo, identidad sexual, creencia, etc.).

La escritora Rosario Raro ${ }^{87}$, en el documental Lletra de dona (Maribel Rocafull, 2017), dice que cada vez se visibilizan más las mujeres que escriben porque son muchas las mujeres que «escribimos». Como hecho objetivo hay que decir que cualquier paseo por una librería en los últimos años nos presenta un escaparate de novelas escritas por mujeres que hace veinticinco años no encontrábamos. Otras entidades que convocan premios son las entidades públicas, como ayuntamientos y consejerías. Estos premios dirigidos a mujeres tienen un objetivo social lejos del interés económico, suelen tener entre sus funciones fomentar la escritura de las mujeres y ofrecerles un espacio en el que expongan sus trabajos y sean publicados.

La preocupación por la visibilización de las mujeres que escriben es además una preocupación de las escritoras. De hecho, desde 2016 se celebra el Día de las Escritoras $^{88}$. Una iniciativa española que busca visibilizar el trabajo de las mujeres, fomentar la igualdad y recuperar el legado de mujeres escritoras.

La necesidad de estos premios es incuestionable, ya que las mujeres todavía no están en igualdad de condiciones en el mundo editorial. Ana S. Pareja y Laura Freixas así lo atestiguan: «Las estadísticas que revisé en 2014 a raíz del Year of

\footnotetext{
${ }^{87}$ Rosario Raro es una escritora castellonense que ha desarrollado la mayor parte de su producción, hasta el momento, en relatos cortos y cuentos. Ganadora de diversos premios, como el premio de relatos cortos Ciudad de Huelva, el premio Magda Portal del Ministerio de la Mujer de Perú, Cruzando Culturas, Ateneo Ciudad Galdós de Las Palmas de Gran Canaria, Igualdad de Aranda, Mujer Kimetz Elkartea de Ordizia, Palabras de Mujer, entre otros. Fue finalista del premio internacional de novela Vargas Llosa de la editorial Alfaguara, y una de las dos mujeres españolas finalistas en el premio de escritura literaria Virtuality Caza de letras de la UAM de México y Alfaguara. Tiene dos novelas en el mercado: Volver a Canfranc (2015) y La huella de una carta (2017), ambas en Planeta.

${ }^{88}$ La fecha de la conmemoración escogida es el primer lunes después del 15 de octubre, fecha del nacimiento de Santa Teresa, reconocida escritora española del siglo XVI. La iniciativa parte de la Biblioteca Nacional, la Asociación Clásicas y Modernas y la Federación Española de Mujeres Directivas.
} 
Women Writers no eran muy alentadoras. Sigue habiendo un porcentaje muy inferior no sólo de mujeres que publican sino de mujeres que ejercen la crítica literaria y de libros escritos por mujeres reseñados en los medios tradicionales» (Pareja en Caballero, 17 de octubre de 2017: en línea).

Laura Freixas, presidenta de Clásicas y Modernas, en la misma línea señala:

Es un espejismo que el papel de la mujer en la literatura haya aumentado. Los premios de prestigio son un buen termómetro para demostrar que no ha sido así. Es cierto que hay algunas escritoras que venden mucho pero como lo hacen algunos escritores. Sin embargo, corre la idea de que las mujeres vendemos más, lo cual nos asocia a una literatura comercial y, por tanto, de menor calidad. De igual manera, somos reconocidas en los premios más populares pero no en los de prestigio. Y es grave, porque no es el Planeta lo que van a leer nuestros nietos ${ }^{89}$ (Freixas en Caballero, 17 de octubre de 2017: en línea).

Como hemos visto la situación de las mujeres en la novela negra está cambiando, se visibilizan más sus relatos, se da voz a las escritoras en espacios que los tenían vetados. Sin embargo, la igualdad todavía parece lejana, de ahí el interés por realizar una tesis como ésta, que mediante un análisis crítico se propone entender qué hay, cómo se corresponde o no con la realidad y, sobre todo, nos

\footnotetext{
${ }^{89}$ En este caso Freixas plantea la cuestión de la pervivencia de una obra y utiliza la crítica a los premios comerciales, un argumento esgrimido por gran número de escritoras y escritores y crítica y críticos. Fernando González-Ariza (2004) señala que la sobreabundancia de premios no es per se negativa, sin embargo, esto conlleva consecuencias que no son positivas. «Los premios están en una relación triangular entre el arte del que supuestamente se trata, el interés económico y las determinaciones sociopolíticas» (Martínez Cachero en González-Ariza, 2004: 16). Así los premios literarios se dividen en dos categorías: premios de editoriales cuyo objetivo es comercializar esos títulos y premios otorgados por la buena reputación. En el primer caso, las ventas se aseguran con marketing y, en el segundo caso, el prestigio asegura las ventas porque se entiende que la obra tendrá calidad. Las críticas y críticos literarios no suelen entender la relación entre literatura y mercado, ya que entienden la literatura como una disciplina artística no un producto comercial. Hay que reconocer que estos premios publican títulos que tienen una amplia aceptación entre el público y las escritoras y escritores por la dotación económica. González-Ariza (2004) ahonda en esta idea señalando que estos premios crean literatura que se ajusta a los principios dominantes socialmente. Hecho que no discutimos. Sin embargo, en nuestra opinión es precisamente la popularidad de estas novelas las que las convierte en instrumentos extraordinarios para introducir estereotipos subversivos y presentar modelos alternativos positivos lo que los convierte deseable. Un ejemplo es el caso del Premio Planeta 2016, Dolores Redondo, que hemos comentado con anterioridad.
} 
enseña que no es lo mismo lo que declaramos en nuestra vida diaria y las creencias implícitas con las que nos manejamos en ese día a día.

\subsection{Aproximación a las novelas negras periféricas en España}

A lo largo del capítulo hemos repasado lo que ha sido la evolución de la novela negra en España desde sus inicios hasta la actualidad sin centrarnos en lo que se puede denominar novela negra periférica: la novela negra catalana, la novela negra gallega y la novela negra en euskera. A continuación realizaremos un breve repaso a las tres literaturas periféricas que se producen en España.

\subsubsection{Novela negra catalana}

El concepto de novela negra catalana hace referencia a la novela que se escribe en Cataluña, Comunidad Valenciana, las Islas Baleares, y está escrita en catalán. La primera novela negra en catalán en realidad fueron traducciones de los clásicos: Poe, Conan Doyle, entre otros.

Antes de la guerra, aparecen los primeros ejemplos de novela negra catalana que no son traducciones: Cèsar August Jordana escribe El collar de la Núria (1927) y Mercè Rodoreda, Crim (1936), que está escrita en clave humorística. Pero será después de la guerra cuando el género negro comienza a destacar: Rafael Tasis (1906-1966) publicará La Bíblia valenciana (1955), que entronca con el subtipo enigma; És hora de plegar (1956) entraría dentro de la categoría hard-boiled; finalmente, Un crim al Paralelo (1960) introduce algunos personajes que se convertirán en seriales (comisario Vilaguy y el periodista Caldes). De todas maneras, el interés y compromiso de Tasi va más allá del género, es un compromiso con la lengua catalana, como señala Salvador Balcells (2014: 219): 
Tasis, es tractava d'una clara voluntat de resistència i de servei a la llengua en un context totalment advers. Intentar guanyar nous lectors en català quan la llengua estava totalment prohibida a l'ensenyament, ni que fos amb obres de poc tonatge literari, era missió pràcticament impossible. I, tanmateix, ho van intentar. I és que les seves aportacions en català són un intent normalitzador de la llengua catalana.

Poco después, llegará Manuel Pedrolo (1918-1990), que ya hemos mencionado en el epígrafe «Novela negra durante la Dictadura (1939-1975)», como precursor de la novela negra española. Algunas de sus obras más importantes son: L'inspector arriba tard (1960), Joc brut (1965) i Mossegar-se la cua (1968). Como director de la colección La Cua de Palla (1963-1970) ayuda a promover la novela negra tanto en Cataluña como en el resto de España. Realiza una importante labor de traducción de los clásicos anglosajones y franceses, especialmente la obra de George Simenon, pero también las novelas de Agatha Christie, etc., que no tiene el éxito esperado por el escaso número de lectoras y lectores en catalán, al no existir la escolarización en catalán, sin olvidar que en castellano existía una amplia oferta más económica, de la que ya hemos hablado en este capítulo. A pesar de esta situación en la década de los setenta comienzan a aparecer algunos autores autóctonos con novela propia, como Joan Carandell i Maromon (seudónimo de Lloreç Sant Marc, 1901-1988), autor de Males companyies (1970), Ramón Planes i Izabal (1905-1989), Crim al carrer Tuset (1973) o Jordi Carbonell (1924-2006), Un home qualsevol (1979). Algunas escritoras, de las que hablaremos en el siguiente capítulo brevemente, también aparecen en el panorama de la novela negra catalana: Maria Aurèlia Capmany (1905-1989) o Nuria Minguez (1936- ), entre otras.

Jaume Fuster (1945-199) será el escritor que impulse definitivamente la novela negra en catalán con títulos como De mica en mica s'omple la pica (1972), Tard, sessió contínua, 3.45 (1976), entre otras. Fuster alternará, como otros autores contemporáneos, por ejemplo Vázquez Montalbán ${ }^{90}$, su labor crítica y la novela de

\footnotetext{
${ }^{90}$ Aunque Manuel Vázquez Montalbán es catalán, no lo incluimos en este apartado porque su producción literaria es mayoritariamente en español.
} 
ficción con las que va sentando las bases de lo que será el género negro catalán hasta nuestros días. Fuster trabaja para difuminar las barreras entre alta y baja literatura, considerando que sólo hay buena y mala literatura e intentado alejarse de las etiquetas. «Afirmava que les fronteres entre els gèneres i els llenguatges són sempre difuses, i que de fet aquestes fronteres difuses de la literatura s'imbriquen amb les de multitud d'altres produccions existents en l'àmbit més general de la cultura» (Aritzeta, 2014: 167).

En los años ochenta, en el entorno catalán, igual que sucede a nivel español, se dan las condiciones para el crecimiento de la novela negra catalana en catalán. Este grupo de autoras (y autores) catalanas es muy numeroso e incluye escritoras y escritores exclusivamente de género negro y otras (y otros) que ocasionalmente publican en novela negra: Joan Fuster (La corona valenciana, 1982), que continúa con su comprometida actividad literaria, el colectivo Ofèlia Dracs ${ }^{91}$ (Negra $i$ consentida, 1983), Josep Maria Palau i Camps (Assassinat al club dels poetes, 1983), Ferran Torrent (No emprenyeu el comissari, 1984; Penja els guants, Butxana, 1985; Un negre amb un saxo, 1987; Gràcies per la propina, 1995); Albert Draper (col-lectiu literari format per Emili Castellanos y Miquel Colomer, Vuit dies de juny, 1987); Maria Antònia Oliver (Estudi en lila, 1985); Antoni Serra (El blau pàl-lid de la rosa de paper, 1985); Andreu Martín (Muts i a la gàbia, 1986; Crònica negra, 1988; Barcelona Connection, 1989); Magí Rosselló (Faraó, 1988); Margarida Aritzeta (El correu de Trípoli, 1990, etc.); Isabel-Clara Simó (La veïna, 1990); Toni Cucarella (Bogart \& Bogart, 1993.); Pep Coll (L'abominable crim de l'Alsina Graells, 1999); entre otros.

\footnotetext{
${ }^{91}$ El colectivo lo formaron a lo largo de su vida: Josep Albanell, Margarida Aritzeta, Jaume Cabré, Assumpció Cantalozella, Joaquim Carbó, Miquel Desclot, Joana Escobedo, Jaume Fuster, Isidre Grau, Josep M. Illa, Quim Monzó, Maria-Antònia Oliver, Carles Reig, Joan Rendé, Xavier Romeu, Josep-Lluís Seguí, Antoni Serra, Joaquim Soler, Roser Vernet y Vicenç Villatoro. Su objetivo era reivindicar diferentes géneros literarios escritos en catalán; desde la novela erótica a la fantástica, la de ciencia ficción, y, desde luego, el género negro.
} 
La novela negra catalana, a diferencia de otras novelas periféricas, crece muy rápido durante la Transición y, especialmente, en los primeros años de ésta gracias a colecciones como: Seleccions de la Cua de Palla (1985-1997), del grupo Edicions 62, dirigida como hemos visto en el apartado anterior por Xavier Coma y dedicada exclusivamente a la novela negra, y La Negra (1986-1998), del grupo La Magrana, que incluía autoras y autores catalanes y traducciones de novelas extranjeras.

Ana María Villalonga (2013: 54) señala que se está produciendo una deriva consumista que afecta a la novela negra catalana como al resto de literaturas del género lo que «s'allunya sovint de l'esquematisme narratiu anterior [...] per pasar a reflectir la vida i quotidianitat dels personatges». En el caso catalán, finales del siglo XX y principio de siglo XXI supone una etapa de retroceso en la publicación de novela negra catalana debido al cierre de las colecciones que más esfuerzos habían hecho por la normalización lingüística en este ámbito. Pero se producirá una recuperación en la última década gracias a pequeñas editoriales independientes ${ }^{92}$, y la consolidación de las políticas de promoción lingüística, entre otros factores. Algunas autoras (y autores) destacadas son: Jaume Benavente (1958- ), Agustí Vehí i Castelló (1958-2013), Rafael Vallbona i Sallent (1960), Teresa Solana (1962- ), Lluís Bosch Albert (1964- ), Juli Alandes Albert (1968- ), Xavier Aliaga (1970- ), Sebastià Bennasar i Llobera (1976- ), Sebastià Jovani (1977- ), o Marc Moreno (1977- ).

\footnotetext{
${ }^{92}$ Ya hemos mencionado que las nuevas tecnologías ayudan a la autopublicación, pero también a la aparición de pequeñas editoriales que desarrollan su actividad a nivel local. La independencia de estas empresas les permiten publicar títulos que no encajan en las colecciones de los grandes grupos de la industria editorial.
} 


\subsubsection{Novela negra gallega}

Las novela negra gallega, entendida como novela negra escrita en gallego, presenta un desarrollo tardío ${ }^{93}$ respecto al de otras literaturas de género negro en España, no será hasta $1984^{94}$ cuando esta se produzca (Ventura, 2012). Crime en Compostela (1984) de Carlos G. Reigosa (1948- ) es considerada como la novela que inaugura el género negro gallego. El protagonista es Nivardo Castro y su compañero de aventuras es Carlos Conde. Reigosa trata un gran tema social contemporáneo como es el narcotráfico. Las siguientes novelas de la serie son: $O$ ministerio de baco perdido (1988), A guerra do tabaco (1996) y Narcos (2001).

Hemos hablado en el epígrafe anterior que la novela negra nórdica está de moda y exporta sus características a otras literaturas, sobre todo en lo que se refiere a la creación de series de detectives, el caso gallego no es una excepción. Domingo Villar (1971- ), siguiendo esta corriente dominante, crea al detective Leo Caldas. Sánchez Zapatero (2014b: 814) describe al personaje como «taciturno, melancólico, tímido y solitario». Villar humaniza al detective asignándole algunas fobias y aficiones como el vino, aspectos que se van conociendo a través de las diferentes entregas de la serie como característica de la novela negra contemporánea y que no afecta únicamente a la novela negra gallega, como hemos visto antes. Caldas es un detective que, al estilo de las actuales novedades literarias en España (Redondo, García Sáenz de Urturi, entre otros), transita entre lo urbano y lo rural en sus casos. Tránsito que va más allá de lo literario y, al tratarse de espacios reales se traspasa la ficción y se crean rutas turísticas para las y los fans de estas series, ahondando de esta manera en la característica de producto

\footnotetext{
${ }^{93}$ La definición que hacemos de novela negra gallega deja fuera de este apartado a autoras como Emilia Pardo Bazán, por eso hablamos de inicio del género en los ochenta. Tampoco se incluyen autoras (y autores) contemporáneas como Mercedes Castro (escritora que compone el corpus de esta tesis) porque sus producciones son mayoritariamente en español.

${ }^{94}$ Hay que tener en cuenta que será con la llegada de la democracia cuando se vuelven a dar las condiciones, por motivos sociales, políticos, culturales, para desarrollar la actividad literaria en lengua gallega.
} 
comercial95. Sánchez Zapatero (2014b: 811) señala que Domingo Villar junto a «Lorenzo Silva, Alicia Giménez Bartlett, Eugenio Fuentes, Rafael Reig, José María Guelbenzu, Carlos Zanón o Willy Uribe» son los referentes de la novela negra contemporánea cuya producción literaria coincide con los años noventa y principios del siglo XXI, momento de crecimiento y consolidación de la novela negra debido a diferentes factores como: la tradición del género negro que nació durante la Transición; el cambio socioeconómico y político que permite la adecuación a la estructura de la novela negra; la difusión del género mediante congresos, festivales, etc.; el mayor interés de las editoriales y las lectoras y lectores; entre otros. La producción de las autoras o autores que mencionamos ha sido uno de los referentes de la novela negra española contemporánea, condición que compartiría el autor gallego Domingo Villar y otras autoras y autores que también escriben novela negra en gallego.

Miguel Anxo Fernández (1955- ) crea al personaje Frank Soutelo, hijo de padres gallegos exiliados, y que vive en Malibú, donde transcurren las novelas. Las características de Soutelo son similares a las de los detectives de la hard-boiled americana. Los títulos que componen esta saga son: Un nicho para Marilyn (2002), Luar no inferno (2006), Tres disparos e dous friames (2008) y Luna de cobiza (2011). Diego Ameixeiras (1955- ) es el padre de Horacio Dopico, y sus novelas más destacadas: Baixo mínimos (2004), O cidadán do mes (2006) y Asesinato no Consello Nacional (2010). A los anteriores podemos añadir a Bieto Iglesias (1957- ) que da vida a Gumersindo Nespereira, o Manuel Forcedela (1958- ), que escribe sobre el investigador Toni Barreiro (Sánzhez Zapatero, 2014b).

Por otra parte, el autor Suso de Toro (1956- ) escribe Ambulancia (1990) y Calzados Lola (1997), que no se ajustan exactamente a la escritura de la novela negra, pero Villa (2014: 811) considera que «han de encuadrarse dentro de la narrativa negra por la importancia que en ellas adquieren la violencia, el delito y el submundo criminal». El autor gallego explora las razones por las cuales alguien delinque reflexionando sobre la violencia en la sociedad gallega contemporánea.

\footnotetext{
${ }^{95}$ Este fenómeno se produce tanto a nivel internacional como nacional. Por ejemplo, se han creado rutas para visitar los lugares donde se rodó la saga del Hobbitt. En España, se han establecido las rutas por espacios de la Trilogía del Batzán (http://kilometrosquecuentan.com/ruta-trilogia-baztan/. Fecha de consulta: 5 de junio de 2017).
} 
Las novelas de de Toro presentan numerosas dualidades, como urbano-rural, nuevo-viejo, realidad-fábula, etc.

Podemos concluir que la juventud de la novela negra gallega hace que nazca con las características que presenta el género en la actualidad: serialidad, espacios urbanos y rurales, temas sociales actuales, etc.

\subsubsection{Novela negra en euskera}

A continuación trataremos la novela negra en euskera, con este término haremos referencia a la producción realizada en lengua vasca.

Txema Arinas (20 de mayo de 2016: en línea) considera que se escribe y publica mucho en euskera

[...] porque existe, tanto un sistema educativo en euskera que garantiza la competencia de los lectores que dejan la escuela sabiendo leer y escribir en dicho idioma, como por la existencia de una tradición literaria que viene de antaño y que tras sufrir todo tipo de restricciones durante los tiempos más duros de la dictadura franquista adquirió una pujanza lo suficientemente grande

Las obras escritas en euskera, de cualquier género, en opinión de Ramón Saizarbitoria (en Arinas, 20 de mayo de 2016: en línea), son de gran calidad, lo que ayuda a que se fortaleza la producción literaria en euskera.

Arinas (20 de mayo de 2016: en línea) valora que la novela negra en euskera presenta dos limitaciones para su expansión entre el público vasco: por un lado, la cuestión lingüística durante la Dictadura; por otro, «un rechazo casi que instintivo de buena parte de los lectores euskaldunes a un género en el que la figura del policía tiene un protagonismo tan destacado». A pesar de ello, se pueden rastrear títulos desde mediados del siglo XX como son: Amabost egun Urgainen (Quince días en Urgain, 1955) de José Antonio Loidi (1916-1999), o, en 
Navarra, Dirua Galgarri (El dinero es la perdición, 1962) de Mariano Izeta (19152001).

No será hasta la década de los ochenta cuando aparezca el primer gran éxito de novela negra euskera 100 Street-eko Geltokia (La estación de 100 Street, 1986) escrita por Iñaki Zabaleta Urkiola (1952- ). Podemos observar que aunque haya ejemplos anteriores la eclosión del género negro en lengua vasca es paralelo al fenómeno en Galicia. Y también vemos que en algunas cuestiones hay semejanzas. Zabaleta Urkiola sitúa al protagonista de la novela en Nueva York, donde por motivos políticos se ve involucrado en un asunto de drogas. A partir de ese momento, son numerosas las autoras y autores que suman el género negro a su producción, que se había movido en otros ámbitos hasta ese momento: Alberto Ladrón Arana (1967- ), Jon Arretxe (1963- ) o Iñaki Irasizabal (1969- ), Anjel Lertxundi (1948- ）, Itxaro Borda (1959-） Jon Alonso (1958-) o Aingeru Epaltza (1959-). Especial interés prestamos a Itxaro Borda, que crea a Amaia Ezpeldoi, una inspectora lesbiana de la que hablaremos en el capítulo 3. Por otro lado, Arinas (20 de mayo de 2016: en línea) destaca a Jon Alonso96, «el cual utiliza la novela negra como mera excusa para caricaturizar prototipos y actitudes de un país en permanente querella consigo mismo».

A estas autoras y autores que compaginan su producción de novela negra con otros géneros se les suman autores que desarrollan su producción completamente en el género negro, como Jon Arretxe (1964-2017), que crea la saga del detective Touré, nacido en Burkina-Faso y que vive en el barrio de San Francisco (Bilbao); Iñaki Irasizabal ${ }^{97}$ (1969) «destaca por utilizar el crimen como mera excusa para una disección de la sociedad contemporánea en la que vivimos, lo cual acostumbra a hacerlo sin circunscribirse en exclusiva a la vasca» (Arias, 20

\footnotetext{
96 Katebegi Galdua (La cadena perdida, 1995), Zintzoen saldoan (En el grupo de los honrados, 2012), Hiri hondakin solidoak, (Residuos urbanos sólidos, 2015).

97 Mendaroko Txokolatea (El chocolate de Mendaro, 2005), Gu bezalako heroiak, (Héroes como nosotros, 2009), Igelak benetan hiltzen dira (Las ranas mueren de verdad, 2011), Bizkartzainaren lehentasunak (Las prioridades del guardaespaldas, 2013), Odolaren deia (La llamada de la sangre, 2014), entre otras.
} 
de mayo de 2016: en línea). 0 Alberto Ladrón Arana ${ }^{98}$ (1972- ), que suele colocar como protagonistas a personas corrientes.

Arinas señala que la novela en euskera en las últimas décadas ha corrido paralela al fenómeno que ha supuesto el género a nivel nacional e internacional y que hemos analizado en los epígrafes anteriores, con títulos como: Prime-Time (Jonh Andueza, 2014), Argazki kamara (La cámara fotográfica, Ana Urkiza, 2015), Barre algarak infernutik, (Carcajadas desde el Infierno, M.A. Mintegi Larraza, 2009), Herensuge gorriaren urtea (El año del dragón rojo, Eneko Aizpurua, 2013), Zangotraba (La zancadilla, Juan Kruz Igerabide, 2014), Argiaren Erreinua, (en castellano Las Siete Esferas, Joseba Lozano, 2011).

Todas estas novelas se caracterizan por una cuestión

[...] muy curiosa, idiosincrásica que diríamos, y que no es otra que el rechazo a hacer protagonistas de las novelas a policías de cualquier tipo o a personas relacionadas con la Justicia, de no ser, claro está, como meros instrumentos para criticar precisamente la actividad de los cuerpos policiales (Arinas, 20 de mayo de 2016: en línea).

El desarrollo sociohistórico-político del ámbito de influencia cultural vasca influye directamente en la novela y hace que suelan situar como protagonistas a personas «corrientes» y no a policías con los que una parte de la sociedad vasca ha mantenido tensiones, concluye Arias.

\subsection{Síntesis}

A lo largo del presente capítulo hemos realizado un recorrido por la evolución del género negro en España.

98 Xake Mate (Jaque Mate, 2002), Itzalaren Baitan (En el interior de la Sombra, 2001), Arotzaren Eskuak (Las manos del carpintero, 2006), Ahaztuen Mendekua (La venganza de los olvidados, 2009), Zer barkaturik ez, (Nada que perdonar, 2011), Piztiaren begiak, (Los ojos de la bestia, 2012), entre otras. 
Así, recogiendo velas recordemos que Fernando Colmeiro (1994) coloca el nacimiento del género detectivesco negro en España en el momento de la publicación de la novela de Pedro Antonio de Alarcón, El clavo (1853).

En nuestro país, la primera autora que realiza una aportación a este género será Emilia Pardo Bazán, que a pesar de presentar un relato ajustado a la norma general de la novela enigma de su época, añade un estilo propio y enriquece la fórmula del género policiaco creando a un personaje humano, el detective Selva, contradictorio y moralmente ambiguo, es decir, construye un personaje psicológicamente completo. Ésta será una característica propia de las novelas negras escritas por mujeres, quienes consideran relevante mostrar los entresijos psicológicos de los personajes, generando una ambigüedad que confunde al lector sobre la bondad o maldad de los mismos.

Sin embargo, en los años de la Guerra Civil y la Dictadura, destacará la figura de Manuel Pedrolo, que desde el ámbito catalán contribuye a establecer las características de la novela negra en España. Y en la Transición la aparición de Tatuaje (1974), de Manuel Vázquez Montalbán, supone la apertura de un nuevo periodo para la novela negra española que será muy fructífero. Una novela que se ajusta a la representación de la realidad socioeconómica-política que había vivido España y que se convierte en una especie de diario de la situación social.

En esta línea, con los cambios sociales provocados con la llegada de la democracia, se introducen otras voces en el género: Eduardo Mendoza, Juan Madrid, entre otros. Una de las primeras voces de mujer en el género negro será Lourdes Ortiz, con una novela, Picadura mortal (1979), que no se puede definir como abiertamente feminista, pero que funciona en los márgenes de la norma establecida.

Además, hemos repasado sucintamente los nombres más destacados de lo que son las novelas negras periféricas en España: catalana, gallega y en euskera. Así hemos podido comprobar que mientras la novela negra catalana inicia su andadura al mismo tiempo que la novela negra española y se retroalimentan, las novelas negras gallegas y en euskera manifiestan su eclosión a partir de los ochentas, y será a principios del siglo XXI con el boom del género cuando 
destacarán numerosos nombres de autoras y autores de novela negra en sus lenguas propias. 

CAPÍTULO 3.

ALICIA GIMÉNEZ BARTLETT Y MERCEDES CASTRO: DOS FORMAS DE ENTENDER LA NOVELA NEGRA PROTAGONIZADA POR MUJERES

3.1. Alicia Giménez Bartlett

3.1.1. Alicia Giménez Bartlett: escritora

3.1.2. La saga de Petra Delicado: personajes

3.1.3. La saga de Petra Delicado: sus crímenes

3.2. Mercedes Castro

3.2.1. Mercedes Castro: escritora

3.2.2. Y Punto y Mantis: personajes

3.2.3. Y Punto y Mantis: sus crímenes

3.3. Síntesis 



\title{
CAPÍTULO 3. Alicia Giménez Bartlett y Mercedes Castro: dos formas de entender la novela negra protagonizada por mujeres
}

\author{
Lo que hace que la profesión de escritora sea animada y apasionante \\ es la constante posibilidad de fracasar. \\ Patricia Highsmith
}

La mayoría de los protagonistas de la época de resurgimiento de la novela negra española, como hemos comentado en el capítulo anterior, son detectives, profesionales o aficionados, varones. Sin embargo hay algunos ejemplos que rompen con esta característica. Estos suelen salir de una pluma femenina, y en la mayoría de los casos resultan personajes realmente transgresores.

Por ejemplo, Lourdes Ortiz (1943- ), con Picadura mortal (1979), en que aparece la primera detective de la novela negra española, Bárbara Arena. El personaje se caracteriza como los detectives de la hard-boiled, sobre todo, en lo que a uso de la violencia de refiere. Escrita en plena Transición todavía se observan las heridas de la Guerra Civil y la Dictadura. Los ambientes marginales en los que se mueve Arena están marcados por la heroína99. También encontramos a María Antonia Oliver (1969- ), escritora mallorquina cuya producción se desarrolla en catalán y que también se ha dedicado a la traducción, ha escrito novelas, teatro, poesía. De su mano surge una detective llamada Apolònia Guiu (Lònia) (Estudi en lila, 1985), una reivindicación de su identidad como mujer, pero también de su identidad cultural, lingüística y política como catalana. Vemos en este caso que la autora utiliza esta ficción para demandar otros derechos, diferentes a los relacionados con cuestiones de género. Como personaje, Lònia presenta similitudes y diferencias con el resto de sus compañeras, y sólo cuenta con una aventura hasta el momento:

\footnotetext{
${ }^{99}$ La heroína no era nueva en España, ya que desde principio del siglo XX en sus diferentes formas. Con el fin de la Dictadura el clima de libertad lleva también a una parte de la sociedad a experimentar con las drogas, la heroína se convierte en una epidemia que durará hasta la década de los noventa.
} 
Lònia Guiu, en definitiva, recull la tradició hard-boiled feminista y representa el model de la dona alliberada que s'enfronta a situacions perilloses i violentes. La seva plena independència econòmica i personal o l'absència de lligams emocionals en temes com ara la maternitat i la família fan d'ella un personatge atractiu per als lectors, sobretot si analitzem el context social en què s'escriuen les obres. Tot i aquesta duresa, Lònia mostra també la seva part més sensible i humana amb els seus atacs de ràbia, dolor o impotència que es manifesten amb els plors u els renecs (Bordoy, 2011: 71).

Por su parte, Itxaro Borda (1959- ) crea a Amaia Ezpeldoi, que es una detective rural y bisexual. Esta saga escrita en euskera comienza con Bakean ützi arte (Hasta que nos dejen en paz, 1994) y finaliza, después de un parón, con una cuarta entrega, Boga, boga (2012). Borda ha experimentado con otros géneros, sobre todo poesía, siempre en euskera, también en los márgenes por cuestiones como la lengua comunicativa que usa y por la inclusión de la crítica social en sus relatos (sea en poesía o novela):

Itxaro Borda ha dispuesto, desde supuestos feministas, que la obstinada Amaia Ezpeldoi observe el mundo desde su alteridad y anticonvencionalidad. La detective del País Vasco francés proviene del mundo rural, es euskaldun, y lesbiana; en otras palabras, pertenece a un mundo rural pobre y en extinción, a una minoría lingüística sin amparo legal y a una opción sexual todavía hoy discriminada en Francia; de ahí que su «mirada lesbiana» (Retolaza, 2010: 125) cuestione el avance del capitalismo y los principios igualitarios de la república francesa (Fernández Iglesias, 2014: 223).

Rosa Montero (1951- ), que también comienza a escribir en la Transición, no contará con el beneplácito del público hasta la publicación de La hija del caníbal (1997), una novela negra que está atravesada por una perspectiva crítica feminista. Lucía, protagonista femenina de esta novela negra, encuentra espacio subjetivo para distanciarse de la realidad de su marido secuestrado y vincularse mediante el deseo sexual con otro hombre, en una serie de acciones y de giros subjetivos que concuerdan irónicamente con el arquetipo de la femme fatale. Pero La hija del caníbal propone para esta figura un desarrollo positivo que escapa al castigo que la narrativa tradicional reserva para ella (Zizek en Bonatto, 2012: 74). Teniendo en cuenta los niveles narrativos a cargo de Lucía, estamos frente a un 
collage de novela de aprendizaje o Bildungsroman femenino y novela policial negra, en el que el primero de los códigos contamina y tergiversa, gracias a su planteamiento de género, los presupuestos culturales del segundo.

Entre los escritores que manifiestan su interés por personajes femeninos, encontramos a Lorenzo Silva (1966- ), que escribe la serie de los Guardia Civiles Bevilacqua y Chamorro ${ }^{100}$ (Imagen 7). Esta saga es la que presenta más aspectos en común con la pareja de la Policía Nacional que idea Alicia Giménez Bartlett

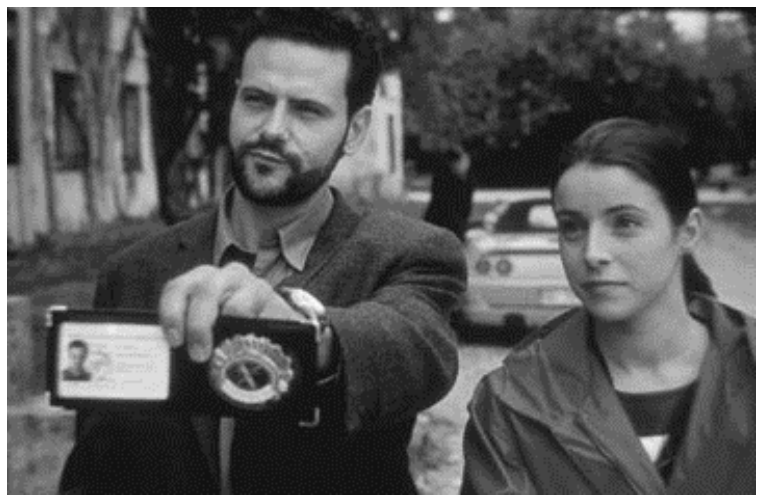

Imagen 7. Fotograma de El alquimista impaciente (Patricia Ferreira, 2002)
(Delicado y Garzón), pues pertenecen a los cuerpos y fuerzas de seguridad del estado y son una pareja mixta. La primera novela de la serie de Rubén Bevilacqua escrita por Silva, El lejano país de los estanques, se publicó en 1998, muy próxima, en el tiempo, al primer título de la serie de Petra Delicado, Ritos de muerte (1996), creada por Giménez Bartlett.

Rubén Bevilacqua, igual que Petra Delicado es una persona culta y formada (estudió Psicología). Aquí la diferencia es que Silva le busca una compañera también con formación universitaria (Derecho). La diferencia de edad es otro rasgo en común, aunque los Guardia Civiles invierten los rangos y las edades. También se diferencia en el hecho de que mientras el escritor madrileño opta porque entre su pareja exista una cierta tensión sexual, Giménez Bartlett sólo hace crecer una sólida amistad entre Petra y Fermín.

Bevilacqua será el narrador, con lo que a lo largo de las diferentes entregas conocemos sus opiniones sobre diferentes temas cotidianos o trascendentales, su posicionamiento moral, etc., tal y como sucede con Petra.

${ }^{100}$ La saga de Bevilacqua y Chamorro se ha adaptado a la televisión con una serie protagonizada por Jesús Noguero y Mariona Ribas, y al cine (Imagen 7) en una película protagonizada por los actores Roberto Enríquez e Ingrid Rubio, El alquimista impaciente (Patricia Ferreira, 2002). 
Silva es un escritor prolífico que cultiva el género negro así como el relato, la narrativa juvenil o el ensayo. Además, ha sido premiado o finalista en diversas ocasiones. Entre sus premios se encuentran los más antiguos y mejor dotados de las letras españolas: el Premio Nadal ${ }^{101}$ con El alquimista impaciente (2000), segundo título de la serie Bevilacqua, y el Premio Planeta, con La marca del meridiano (2012). La entrega más reciente, Donde los escorpiones, se publicó en 2016. Que una de las protagonistas sea mujer, Virginia Chamorro, puede ser atractivo por la visibilización que supone, aunque en 1948 ya hubiese mujeres que pertenecían al cuerpo de la benemérita. Estas «matronas» no portaban armas y no tenían insignias, solían ser viudas o huérfanas de miembros del cuerpo. Las mujeres pudieron acceder a las pruebas de selección a partir de 1988 (promulgación del RD 1/1988 de 22 de febrero, por el que se regula la incorporación de la mujer a las Fuerzas Armadas), un acceso que no fue fácil ya que las instalaciones no estaban preparadas para acoger a mujeres y hubo que publicar una Orden General para solucionar los problemas que se habían observado. No será hasta 1993 cuando ingrese la primera mujer en la Academia

${ }^{101}$ El Premio Nadal de novela es uno de los premios comerciales más importantes de las letras en español. Creado en 1944 por la editorial Destino (desde 1990 pertenece al Grupo Planeta, un grupo editorial y de comunicación español con «vocación europea e internacional», según aparece en su web (2015)), es considerado el premio comercial más longevo de España. Se falla todos los 6 de enero en el hotel Ritz de Barcelona y desde 2010 no tiene categoría de finalista (brevemente fue sustituida por el Premio de novela Francisco Casavella).

La crítica cuestiona el hecho que desde que el Grupo Planeta adquirió Destino los títulos que han sido premiados han ido tomando un carácter más comercial. En esta línea estaría el premio de Lorenzo Silva de 2000, aunque no sea la primera vez que el Premio Nadal se otorga a una novela negra. Francisco García Pavón fue finalista en 1967 con El reinado de Witiza y ganador en 1969 con Las hermanas Coloradas, ambas novelas del ciclo de relatos de Plinio. A nuestro juicio, el Nadal se ha caracterizado por galardonar novelas transgresoras por tratar temas sociales o experimentales, desde Nada (Carmen Laforet, 1944) con la que se inaugura el certamen, pasando por El Jarama (Rafael Sánchez Ferlosio, 1955) o Central eléctrica (Jesús López Pachezo, 1957, finalista). En 1947, el año en que ganó Miguel Delibes con La sombra del ciprés es alargada, la organización tuvo que entregar una mención especial a Ana María Matute, que había quedado finalista con Los Abel, pero que la censura prohibió publicar. Posteriormente, la autora se resarciría al ser ganadora por Primera memoria (1959). Más recientemente encontramos títulos como Historias del Kronen (José Ángel Mañas, 1994). Si bien es cierto que se habían premiado novelas negras, muy diferentes a estos ejemplos, en el momento en que García Pavón es galardonado la novela negra española, como hemos visto en el capítulo dos, era un género que navegaba entre la copia de estilos foráneos y una voz propia. 
General Militar de Zaragoza ${ }^{102}$. En este contexto, la aparición de Chamorro es interesante, sin embargo, no es relevante como sucede en el caso de Petra Delicado. Silva opta por asignar a cada uno de sus personajes el estereotipo socialmente aceptado, mientras Giménez Bartlett mueve las fronteras de estos modelos de feminidad y masculinidad dentro de su convencionalismo al invertir edades y sexo dentro del esquema jerárquico inspectora-subinspector. George Tyras señala que:

Los ingredientes de los textos de Lorenzo Silva son equiparables a los que convocan los libros de Alicia Giménez Bartlett: un dúo actancial de sexo y temperamento opuestos, miembro de las fuerzas del orden (Policía Nacional o Guardia Civil), una narración personal asumida por el protagonista y que deja bastante espacio a la vivacidad oral de los diálogos, una empresa detectivesca que se desenvuelve en los arcanos psico-individuales y se desinteresa de los mecanismos estructurales de la socio-historia. De la misma manera, asimismo, los determinismos estructurales priman en Lorenzo Silva, y lo emocional sustituye el análisis de las relaciones de fuerza sociales (Tyras, 2002: 100).

Tyras (2002) establece que el autor enviste a Bevilacqua de un «carácter moral» y compara los relatos de Silva y Giménez Bartlett calificándolos de «convencionales». No vamos a negar el carácter comercial de ambos autores, pero tampoco podemos dejar de señalar que, en la actualidad, el público lector busca tanto el convencionalismo para seguir la historia, como novedades y transgresiones. Creemos que estos cambios se observan en mayor medida en la novela negra española escrita por autoras contemporáneas y que, en cierto modo, han aprendido de estos dos autores (cuyas últimas entregas de sus series se han publicado muy recientemente, en el caso de Petra Delicado en 2015, Crímenes que no olvidaré, y en el caso de Bevilacqua en 2016, Donde los escorpiones), pero también de otros géneros, asimismo comerciales, y que han creado en las lectoras,

${ }^{102}$ Este dato es significativo si tenemos en cuenta que la Guardia Civil, como hemos señalado en el primer capítulo, es un cuerpo militarizado con todas las consecuencias que esto tiene. Debemos recordar que España tuvo una dictadura militar (1939-1975) basada en los principios del nacionalcatolismo y las mujeres no eran admitidas en el ejército como miembros de «pleno derecho». En caso de trabajar en el entorno militar tenían posiciones subalternas de cuidado como enfermeras o voluntarias para atender y «cuidar» de los soldados. Incluir a un personaje femenino supone un cambio en la representación de las mujeres. 
especialmente, una nueva «necesidad»: verse reflejadas en la ficción. Este aspecto lo desarrollaremos más adelante.

Otro autor que también opta por colocar a un personaje femenino como el centro de su historia es José María Guelbenzu (1944- ), que creó la serie de la juez Mariana de Marco (2001-2017), y que a nuestro juicio resulta interesante. De Marco es independiente, al igual que el resto de compañeras que se dedican de una u otra manera a la investigación y que han perdurado en el tiempo a lo largo de finales del XX y principios del XIX. Mariana de Marco es una profesional eficiente, divorciada, melómana, sibarita, vive a gusto con su soledad, sexualmente plena, aunque sin interés por el compromiso, y un elemento relevante es que la constante en su vida son sus dos amigas: Julia Cruz y Carmen Fernández, antigua Secretaria de Juzgado, con la que tras su traslado ha perdido contacto. Es curioso que el escritor madrileño haya hecho que su protagonista dejara el bufete de abogados en el que trabaja (con su marido y unos socios) después del divorcio, como veremos que le sucede a Petra Delicado, inspectora de policía creada por Alicia Giménez Bartlett. Guelbenzu, sin embargo, no muestra un posicionamiento de género, utiliza un personaje femenino, lo dota de carácter, capacidad, independencia y sensibilidad, como otras de las compañeras mencionadas anteriormente, pero el carácter feminista queda un poco eclipsado. Entre otras cosas porque Guelbenzu está más interesado en mostrar los mecanismos de poder que las relaciones de género. El autor reconoce que la serie de Mariana de Marco comenzó como un ejercicio para conseguir soltura con la escritura (Gordo, 22 de septiembre de 2014: en línea).

En los últimos años son muchas las escritoras que se han sumado a la novela negra y los ejemplos crecen cada año ${ }^{103}$. Con la llegada del nuevo siglo,

\footnotetext{
${ }^{103}$ El Centro Mujeres y literatura. Género, sexualidades, crítica de la cultura fue fundado por Ángels Carabó y Marta Segarra como Seminario de literatura hecha por mujeres en 1990. Situado en la Facultad de Filología de la Universitat de Barcelona edita la revista Lectora: revista de dones $i$ textualitat/ revista de mujeres y textualidad y participa de diferentes proyectos y grupos de investigación con objetivo de «analizar las diferencias de género, raza y orientación sexual desde una perspectiva histórica, social, artística, lingüística y literaria. Explorar e investigar la obra de creación producida por mujeres en un amplio abanico geográfico e histórico, con especial atención a escritoras procedentes
} 
durante los últimos años del siglo XX y principios del XIX, las editoriales publican a numerosas escritoras y la publicidad va directamente dirigida a las mujeres que son consumidoras y cuentan con recursos propios. Desde los años sesenta y setenta las mujeres salieron paulatinamente fuera del hogar. Muchas de las activistas antifranquistas de esos años son universitarias y profesionales, el modelo ya no es el ángel del hogar que cuida de las hijas y los hijos, el marido y la casa, mientras los hombres salen a trabajar para proveer a la familia. A pesar de que continúan los «estereotipos», la situación definitivamente está cambiando. En esta tesis, centramos nuestro análisis en torno a dos autoras en esta línea: Alicia Giménez Bartlett y Mercedes Castro.

¿Por qué hemos escogido a Alicia Giménez Bartlett y Mercedes Castro como autoras centrales de nuestra investigación? La decisión la tomamos en dos fases: la primera nos hace decantarnos por elegir entre las escritoras que se han dedicado a la novela negra en España. Como hemos visto, desde el inicio del género ha habido mujeres que se han decantado por la novela negra. Además, aunque en las últimas décadas el análisis con perspectiva de género ha entrado en las instituciones y en una de sus vertientes se ha dedicado a la visibilización de las mujeres, los esfuerzos para conseguir igual reconocimiento de las aportaciones de las mujeres en el espacio público continúa siendo disparejo, por lo que consideramos que es necesario continuar la tarea. Pero, ¿por qué específicamente Giménez Bartlett y Castro? La primera, Giménez Bartlett, porque la mayor parte de la literatura especializada en este tema la sitúa como la iniciadora del género subtipo

de culturas consideradas hasta ahora periféricas. Restituir la originalidad de escritoras ignoradas o silenciadas en el pasado. Revisar el canon artístico analizando la imagen de las mujeres y de los hombres en el discurso oral, escrito y visual (textos literarios, medios de comunicación, cine y arte)», como señalan es su página web oficial (s.f.). Uno de los proyectos que han impulsado es MUNCE (Mujeres y Novela Criminal en España (19752010)). Este grupo de investigación tenía como objetivo básico elaborar una base de datos de textos en línea para el análisis de narrativas literarias y fílmicas desde una perspectiva feminista y de los estudios de género. Este análisis fue extendiéndose a la representación de las mujeres como figuras de poder, víctimas, criminales y al análisis sobre los modelos de feminidad/masculinidad incluyendo la representación de las mujeres en las series televisivas realizadas en España.

En la actualidad, el proyecto recoge datos de escritoras y sus personajes (investigadoras e investigadores) desde 1975 hasta 2012 y en la página web publica, como noticia, las novedades que aparecen periódicamente. Una página muy viva, ya que las nuevas publicaciones son constantes. Es una excelente guía en la que rastrear los títulos de novela negra escrita por mujeres desde la Transición. 
procedimental (procedural ${ }^{104}$ ) en España. A esto hay que añadir que su producción no está cerrada todavía, es suficientemente amplia para observar los cambios que se han ido sucediendo en su personaje central, la inspectora Petra Delicado. La segunda, Castro, es una autora joven con escasa obra y que se manifiesta consciente de los conflictos de género, así mismo reconoce que con sus personajes pretende realizar una crítica a la sociedad, por lo que las mujeres que protagonizan sus historias son subversivas y contestan a los prejuicios y valores tradicionales de la sociedad, como veremos en este capítulo y el siguiente (capítulo cuarto).

\subsection{Alicia Giménez Bartlett}

Las mujeres, como hemos visto con anterioridad, están ligadas a la novela negra desde sus orígenes: escritoras, investigadoras, femme fatale, víctimas. Para los propósitos de nuestra investigación, las consideramos como autoras e investigadoras. Empecemos por ver quién es quién en el corpus que utilizamos en el análisis.

\subsubsection{Alicia Giménez Bartlett: la escritora}

Alicia Giménez Bartlett (1951- ) (Imagen 8) es una autora muy prolífica que ha abordado géneros muy variados, desde la recreación biográfica de la relación que mantuvieron Virginia Woolf y Nelly Boxall (Una habitación ajena, 1997) en el contexto del grupo de Bloomsbury, hasta géneros como el relato. La última novela

104 Procedimental hace referencia a un tipo de novela negra en el que dentro de una serie o saga cada una de las entregas presenta una historia autoconclusiva, es decir, que empieza y acaba en esa entrega. La coherencia serial suele venir dada por los personajes que se repiten, protagonistas y secundarios, las localizaciones comunes: una ciudad, la casa, los bares, etc. Está «caracterizada por su estética realista, por la utilización de técnicas documentales y por el protagonismo de los agentes de la ley. Como su propio nombre indica, este subgénero de la novela negra acostumbra a mostrar los procedimientos oficiales que se han de seguir para llevar a cabo una investigación» (Sánchez Zapatero, 2004a: 14). 


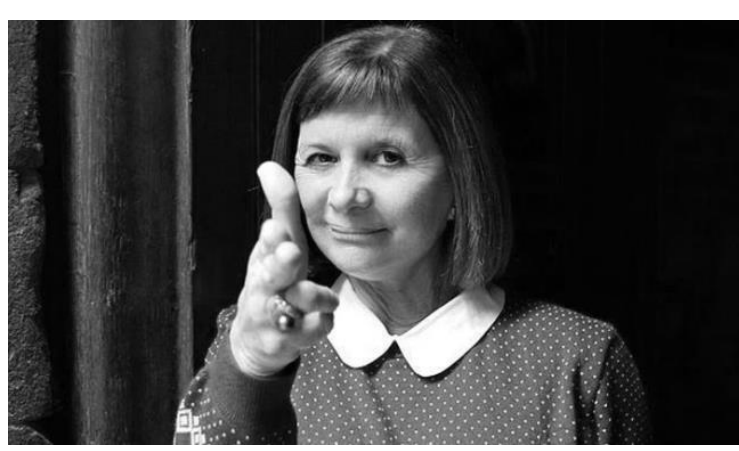

Imagen 8. Alicia Giménez Bartlett que ha escrito se titula Hombres desnudos (2015), ganadora del Premio Planeta, cuyo tema gira en torno a la crisis. Giménez Bartlett la resume, en los siguientes términos: «Uno pierde su trabajo, la otra cierra su empresa, a otra le abandona su marido ante un matrimonio de conveniencia... y de repente se encuentran los personajes

en un régimen de supervivencia sentimental y económica. ¿Hasta dónde nos afecta perder un trabajo? No es un tema sólo económico, hay muchas más consecuencias, como la autoestima, la pareja... Somos seres humanos» (Giménez Bartlett en Lario, 6 de noviembre de 2017: en línea).

Sin embargo, el personaje que más popularidad le ha dado ha sido la inspectora Petra Delicado, cuya saga consta a fecha de hoy de diez volúmenes. La propia autora, en su página web oficial (Bartlett, s.f.) afirma: «Quería un personaje que fuera mujer y que tuviera protagonismo. Porque la mujer en la novela negra o es la víctima, que aparece muerta en la primera página, o es la ayudante de alguien». Esta frase hace referencia a la literatura negra que se había escrito en España hasta la aparición en escena de Petra Delicado.

Giménez Bartlett ha triunfado en otros países, sobre todo en Italia, donde tiene gran cantidad de seguidores, recogiendo la tradición de Pepe Carvalho, que tuvo gran éxito entre el público italiano. La literatura negra de hecho es un género muy popular en Italia, donde encontramos numerosas autoras y autores que la practican, por ejemplo: Giorgio Scerbaneco (1911-1969), Leonardo Sciascia (19211989), Andrea Camilleri (1925-), Loriano Macchiavelli (1934-), Massimo Carlotto (1956-), Marcelo Fois (1960-), o Donna Leon (1942- ) ${ }^{105}$, entre otros y otras.

105 Estadounidense de nacimiento vive en Venecia desde 1981. Su personaje más importante es el inspector Brunetti, al que sitúa en Venecia. Paco Camarasa (2016: 262263) destaca que de la mano de Brunetti la autora nos lleva como turistas por la ciudad. Señala que las críticas han surgido por el hecho de que el inspector Brunetti no sea el típico investigador «cínico desinteresado», diferencia entre la ley y la justicia y se presenta como una persona feliz. Donna Leon emplea sus novelas para la denuncia contra «la 
Por lo que respecta a su actividad en un mundo mayoritariamente masculino, Giménez Bartlett manifestaba, en una mesa del festival Getafe negro, donde participaban otras mujeres que habían trabajado en ámbitos dominados por los hombres:

Sin embargo, en el mundo de la literatura, han tenido opción porque ese diálogo íntimo que se mantiene entre el autor y el lector, «es un vis a vis entre dos chicas, entre una mente femenina y otra», señaló Giménez Bartlett. «Pero no vamos a negar un lugar a nuestro lado al hombre. Cuando empecé era la única mujer que escribía novelas policíacas y mis colegas masculinos me recibieron bien. Si alguien me gastaba alguna broma, yo se la hacía mayor y punto» (Membra, 20 de octubre de 2015: en línea).

Y, lo cierto es que Giménez Bartlett ha conseguido hacerse un espacio en el género negro español. Marie-Soledad Rodríguez (2009) afirma:

Alicia Giménez Bartlett puede aparecer como la primera autora que no sólo acepta las reglas que impone el género sino que crea una referencia ya insoslayable dentro de un producción que, en España, a menos es dentro de una producción que, en España a menos es considera como mayoritariamente masculina (Rodríguez, 2009: 250).

La escritora albaceteña nos da muchas pistas sobre cómo ha creado a su personaje en las numerosas entrevistas que ha concedido para promocional cada uno de sus libros. Giménez Bartlett intenta, según ella misma ha comentado en alguna ocasión, crear un personaje puede llegar al gran público, pero confiesa que en cierto modo Petra Delicado es una especie de alter ego de la escritora. «La que sí ha evolucionado es Petra. [...] Petra está más cabreada que nunca, y la escritora también. La realidad del país ha superado cualquier ficción» (Giménez Bartlett en Vázquez Sallés, 5 de febrero de 2017: en línea).

Iglesia, el poder financiero, la mafia, la trata de blancas, el tráfico de deshechos contaminantes, las farmacéuticas inmorales que envían medicamentos caducados a África, el racismo y la xenofobia, el deterioro de las ciudades, los italianos que se enriquecieron colaborando con el fascismo, el saqueo del patrimonio de las bibliotecas...». A lo largo de sus veinticinco entregas, la serie ha podido enfrentarse con diferentes tipos de injusticias. Camarasa concluye: «Donna Leon se inscribe claramente en el conjunto de la novela negra del sur de Mediterráneo. Brunnetti forma, junto a Carvalho, Jaritos, Montalbano y Montale, el quinteto de la buena mesa». 
Pero, ¿quién es Petra Delicado?

\subsubsection{La saga de Petra Delicado: personajes}

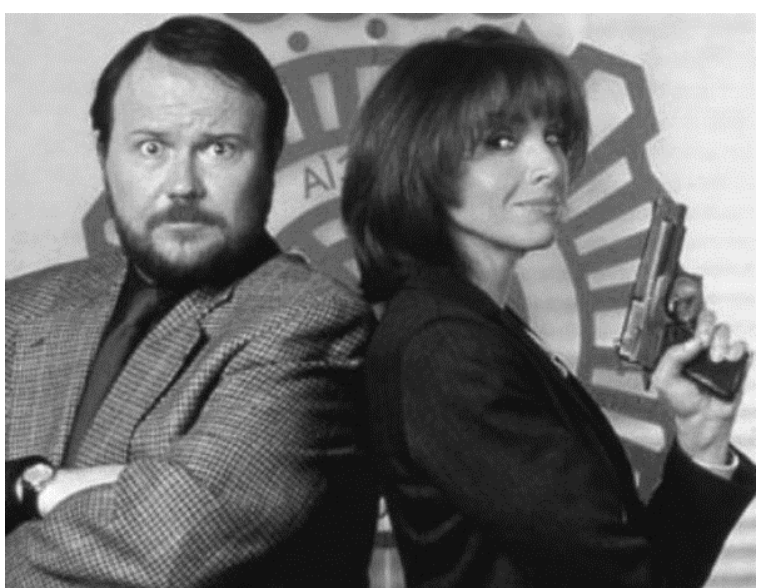

Imagen 9. Fermín Garzón y Petra Delicado
Petra Delicado106 (Imagen 9), el personaje central de la serie negra de Giménez Bartlett, es una inspectora del Cuerpo Nacional de Policía asignada a una comisaría de Barcelona que pertenece a la sección de Documentación hasta que, por una cuestión de falta de personal, comienza a investigar casos criminales. Antes de entrar en la

policía había ejercido como abogada en un bufete importante del que era socio su entonces marido, Hugo. Con la separación decidió dar un giro a su vida, así que se hizo policía y se volvió a casar. El segundo matrimonio fue con un hombre más joven que ella, Pepe, del que también acabó divorciándose porque «había hecho demasiado tiempo de madre y ya no procedía» (Giménez Bartlett, 1996 [2013]: 7).

Detengámonos, antes de continuar, en el nombre con el que bautiza Giménez Bartlett a su personaje, Petra Delicado. Su nombre y apellido forman un oxímoron ${ }^{107}$ (Bados Ciria, 2010; Vázquez Sallés, 5 de febrero de 2015). Petra es la transcripción latina de la palabra aramea Kefás que significa piedra (Petrus). La onomástica la traduce como «firme como la piedra». En la tradición católica cristiana, Pedro (el masculino de Petra) es la piedra sobre la que se edifica la Iglesia. El evangelio de Mateo (16: 17-18) relata: «Jesús le respondió: "Feliz tú, Simón, hijo de Juan, porque eso no te lo ha enseñado la carne ni la sangre, sino mi Padre que está en los cielos. Y ahora te digo: Tú Pedro, o sea Piedra, y sobre esta

\footnotetext{
106 La serie Petra Delicado fue adaptada a la televisión por Telecinco con 13 capítulos (1999). Ana Belén interpretaba el papel de Petra Delicado, mientras que Santiago Segura encarnaba a Fermín Garzón.

107 Figura retórica por la que dos palabras de significado contradictorio se complementan.
} 
roca edificaré mi Iglesia, y los poderes del Infierno no la podrán vencer». Petra es dura. Su apellido, por el contrario, Delicado, evoca imágenes contrarias, suave, tierno, débil, etc. Cualidades que tradicionalmente se asignan a las mujeres. Esta paradoja es una más de las que presenta el personaje. Concepción Bados Ciria (2010) describe a la detective en los siguientes términos:

[...] por un lado, la lucha entre el ser y el parecer en un mundo dominado por los varones, en el cual ella se declara feminista convencida; por otro lado, sus planteamientos éticos y humanos, que no coinciden, casi nunca con los duros y arduos métodos policiales; por último, el conflicto entre sus obligaciones profesionales y sus emociones que parecen estar siempre en equilibro (Bados Ciria, 2010: 41).

Giménez Bartlett, que utiliza el recurso de la ironía a lo largo de toda la serie, hace un guiño cómplice a la lectora y lector desde el momento en que presenta el personaje. Recurso que se extiende a su compañero, Fermín Garzón, el complemento de Petra. En este caso el nombre debía ser eufónico ${ }^{108}$ (Vázquez Sallés, 5 de febrero de 2015). Fermín, también es un nombre de origen latino derivado de Firminos, patronímico de Firmus (Firmo), que significa sólido. Esto sería lo que tienen en común inspectora y subalterno. Garzón, por otra parte, se convierte en un descriptor del personaje, ya que etimológicamente deriva del francés garçon que significa muchacho o mozo (Monlau, 1856). En el siglo XI significaba criado o sirviente. En cierto modo la posición que ocupa el subinspector en la jerarquía policial. La personalidad de este personaje también queda dibujada a través de su nombre, es perseverante $y$, en ocasiones, enérgico. Sus interrogatorios suelen buscar una confrontación más física. Al mismo tiempo es el ayudante de Petra.

Giménez Bartlett nos presenta a una mujer voluntariosa, obstinada, cabezota, profesional, tenaz, es consciente en todo momento de su posición en un mundo de hombres. En ocasiones, se muestra dura con los subordinados, pero siempre para ocultar sus sentimientos. Quiere vivir sola, sin compromisos, manteniendo relaciones ocasionales e intensas, le gusta leer un buen libro y la música de Beethoven, de Chopin, el jazz. Al comienzo de la serie Petra declara: «Se

${ }^{108}$ Eufónico es relativo a la eufonía, es decir, que suene bien, armonioso. 
me presentaba la oportunidad de vivir sola en un lugar tranquilo, lo cual debía ser considerado como otra ocasión de cambiar» (Giménez Bartlett, 1996 [2013]: 6).

Alérgica a la maternidad hasta que conoce a Marina, una testigo del robo de su pistola, y cae por tercera vez en el «delito» del matrimonio, con Marcos Artigas, un arquitecto polidivorciado, como Delicado, con el que acaba «criando» cuatro hijastros (Federico, de 16 años, los gemelos Hugo y Teo de 12, y la pequeña Marina de 8) en una especie de custodia compartida con las respectivas madres de los más jóvenes. Una situación que en ocasiones la desborda y en otras le encanta, especialmente su relación con la pequeña Marina. En resumen, como señala Trotman, «Giménez Bartlett has created a complex multidimensional female character whose plausibility resonates with millions of readers in numerous countries -including women who describe themselves as feminist and those who do not» (Trotman, 2011: 78).

Petra Delicado tiene una «voz propia», Giménez Bartlett opta por usar la primera persona en sus relatos. Esto favorece que la lectora y lector conozca los procesos mentales por los que junta las piezas del puzzle que es la investigación de un crimen, pero también qué opiniones tiene sobre diferentes temas como: su situación laboral, las relaciones personales, la miseria, la riqueza, el matrimonio, la maternidad, etc. Si la seguimos a lo largo de la serie en este proceso reconocemos que al tiempo que descubre la identidad criminal se descubre su propia identidad.

Chung-Ying Yang (2010: 596) considera que la narración en primera persona sitúa a Petra dentro de una institución tradicionalmente vinculada «con la autoridad y la represión». La inspectora intenta así «deconstruir las representaciones estereotipadas negativas femeninas» que representan a las mujeres como pasivas y que critican su participación en el sistema patriarcal. 


\subsubsection{La saga de Petra Delicado: sus crímenes}
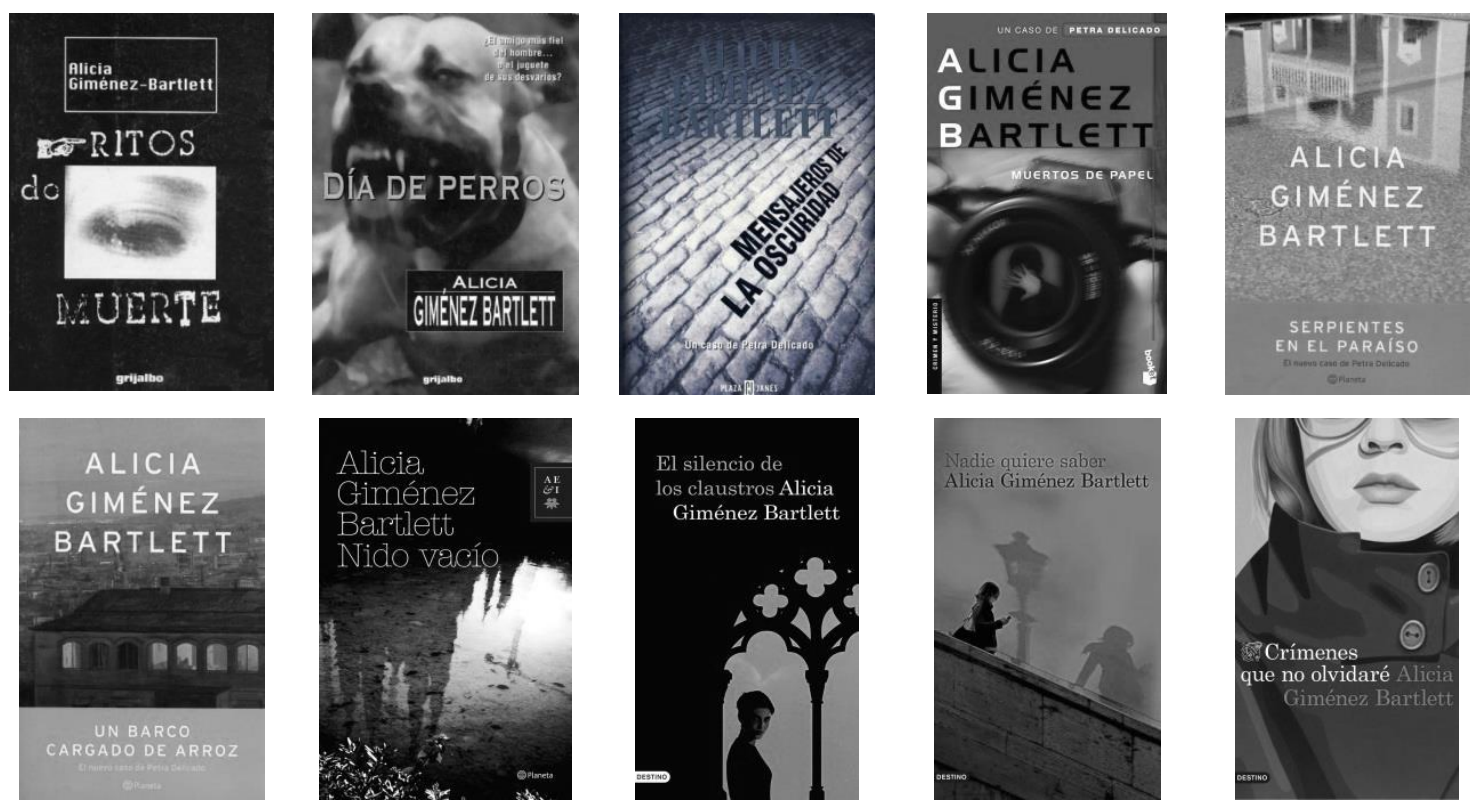

Imagen 10. Portadas de la saga de Petra Delicado (de derecha a izquierda y de arriba abajo). Ritos de muerte (1996), Días de perros (1997), Mensajeros de la oscuridad (1999), Muertos de papel (2000), Serpientes en el paraíso (2002), Un barco cargado de arroz (2004), Nido vacío (2007), El silencio de los claustros (2009), Nadie quiere saber (2013), Crímenes que no olvidaré (2015).

A continuación pasaremos a repasar brevemente las novelas de Alicia Giménez Bartlett que componen el corpus de nuestra tesis: Ritos de muerte (1996 [2013]), Días de perros (1997 [2013]), Mensajeros en la oscuridad (1999 [2013]), Muertos de papel (2000 [2013]), Serpientes en el paraíso (2003 [2013]), Un barco cargado de arroz (2004 [2013]), Nido vacío (2007 [2013]), El silencio de los claustros (2009 [2013]), Nadie quiere sabe (2012) y Crímenes que no olvidaré (2015) (Imagen 10).

La primera de las novelas de la saga de Petra Delicado es Ritos de muerte (1996 [2013]). En ella se nos presenta a la inspectora que acaba de mudarse después de su divorcio a una casa en el barrio de Poblenou donde intenta crear un hogar, un oasis de tranquilidad. Trabaja en el Departamento de Documentación, pero la falta de personal le da una oportunidad para investigar un caso, por 
primera vez. El compañero que le asignan es Fermín Garzón, un policía veterano, que acaba de llegar a Barcelona desde Salamanca. La inversión de los papeles de jefa-subordinado supone un elemento subversivo en la novela negra tradicional.

El comisario deja claro este aspecto al encargarle a Petra su primer caso y asignarle a su compañero:

- Si se espera aquí un momento le presentaré al subinspector Garzón que va a ser su compañero; quiero decir que estará bajo su mando.

Eso era lo que quería decir el comisario e hizo bien en precisarlo, porque si yo era inspectora se debía a los méritos de mi graduación, jamás había tenido a nadie bajo mis órdenes desde que empecé (Giménez Bartlett, 1996 [2013]: $10)$.

Petra y Fermín se complementan perfectamente, desde esta primera entrega, porque son opuestos perfectos: mujer-hombre, clase privilegiada-clase obrera, culta-poseedor de conocimientos populares, etc. Por otro lado, en ocasiones invierten lo que serían los roles tradicionales. Delicado es dura, como los detectives clásicos de la hard-boiled, malhablada, sexualmente activa... mientras que Garzón se presenta en este momento como conservador y controlado en sus actitudes.

La pareja de policías investiga una serie de violaciones, en esta primera novela, que llevan a la muerte del sospechoso (Juan Jardiel) y la detención de su novia, Luisa. Ambos habían sido criados por la madre del primero, una mujer que había perturbado a sus hijos. Petra la define así: «Su madre adoptiva allanó el camino hacia un carácter rozando lo patológico. El dominio total de una mujer dura y amargada, llena de odio» (Giménez Bartlett, 1996 [2013]: 226).

En Días de perros (1997), el segundo volumen de la serie, la víctima es «un hombre de un medio muy humilde» (Giménez Bartlett, 1992 [2013]: 281) al que le han dado una paliza y el único testigo es su perro, muy feo, al que llaman Espanto. En esta ocasión, los límites de las vidas profesionales y personales de Petra y Garzón se confunden. Ambos encuentran parejas mientras están investigando el 
caso. Petra empieza algo con un veterinario y Fermín encuentra a dos mujeres muy diferentes: Valentina Cortés ${ }^{109}$ y Ángela Chamorro ${ }^{110}$. Garzón le pide matrimonio a Valentina ${ }^{111}$, lo que nos da pie a conocer a un hijo que trabaja y vive en Estados Unidos y con el que no tiene apenas trato. La boda no se celebra porque Valentina es asesinada. En este caso, Giménez Bartlett opta por presentar a mujeres fuertes, las novias de Garzón. Además, vemos como éste empieza a modificar sus creencias tradicionales por una conducta más moderna. Fermín que siempre había estado atendido por mujeres (madre, esposa y dueña de la pensión) debe aprender a cocinar y mantener su propio apartamento, ahora que se ha ido a vivir solo (Petra le enseña cómo comprar y a cocinar algún plato sencillo).

Mensajeros de la oscuridad (1999), la tercera novela de la serie, se centra en la investigación de unos penes amputados que llegan por correo a Petra. Nos parece realmente significativo que Petra reciba los falos, un símbolo de masculinidad (¿cercenada?). En un primer momento, parece que la inspectora se ha convertido en el centro del caso por haber salido en la televisión para hablar del caso anterior. Finalmente, sabremos que no es la única razón. Julieta, su asistenta, estaba también involucrada en el asunto. Las pesquisas llevan a la pareja de policías a realizar su primer viaje internacional. Van a Rusia para buscar información sobre el origen de la secta que está detrás de estos macabros envíos donde tiene un pequeño romance con su homólogo de la policía de Moscú, Alexander Rekov.

\footnotetext{
${ }^{109}$ Valentina Cortés, una entrenadora de perros y tiene un rottweiler. Petra la califica como una «mujer muy abierta y cordial» (Giménez Bartlett, 1997 [2013]: 270), «bien plantada, llamativa y enérgica, justo el tipo de mujer que podía gustarle al subinspector» (Giménez Bartlett, 1997 [2013]). Siempre se mostraba: «rozagante, hermosa y llena de vida, no parecía pesarle demasiado el triángulo amoroso» (Giménez Bartlett, 1997 [2013]): 369).

${ }^{110}$ Ángela Chamorro es una experta en perros, «la mejor experta en perros del país» (Giménez Bartlett, 1997 [2013]: 277). Tenía una librería, Bestiarium, y una mastín de los Pirineos llamada Nelly. «Rondaba la cincuentena, tenía bonitos ojos color avellana e iba vestida con el mismo gusto discreto y tranquilizador que había utilizado para decorar su tienda. Llevaba el pelo entrecano recogido en un frondoso moño tras la nuca» (Giménez Bartlett, 1997 [2013]: 277). Era viuda y amaba a los perros.

${ }^{111}$ Garzón duda sobre a cuál de las dos debe elegir. Finalmente le dice a Petra: «Valentina me divierte y Ángela me halaga, nunca había conocido antes esas sensaciones» (Giménez Bartlett, 1997 [2013]): 315), así que se decanta por la relación con Valentina.
} 
En Muertos de papel (2000) la víctima es un periodista del corazón. Los sospechosos pertenecen al mundo del papel cuché, pero también la política (Ministro de Sanidad). La acción transcurre entre Barcelona y Madrid, donde Petra hace migas con el compañero de la comisaría madrileña recién divorciado. Durante la investigación, Amanda, la hermana de Petra, que tiene problemas con su marido y debe de decidir si le pide el divorcio, aparece en casa de la inspectora. Delicado está preocupada por ella, que mantiene varios affaires mientras está de visita con el inspector Moliner y con un miembro de la brigada de estupefacientes, Guillermo Franquesa.

Serpientes en el paraíso (2003) presenta la muerte de un importante abogado que vive en una urbanización de lujo. Los sospechosos, como en otras ocasiones, pertenecen a todas las clases sociales desde los socios y sus mujeres hasta el personal de servicio. El tema de maternidad se representa en diferentes facetas, por un lado, el deseo de ser madre a toda costa (tratamientos de fertilidad) $y$, por otro, la necesidad de renunciar a esa maternidad cuando se tiene que migrar para cuidar a las hijas e hijos de esas personas.

Garzón tiene sus propias cuitas. En sus vacaciones en Ibiza ha conocido a las hermanas Enárquez (Emilia y Concepción), pertenecientes a la clase alta catalana, Fermín siente que su relación es imposible por la diferencia de clase. Petra, en esta ocasión, se hace amiga de Malena Puig, una de las mujeres de la urbanización. Su amistad obliga a la inspectora a plantearse sus propias elecciones vitales.

En la sexta novela de la saga la inspectora y el subinspector, Un barco cargado de arroz (2004), se sumergen en un ambiente diametralmente opuesto a la entrega anterior. En esta ocasión, el muerto será un mendigo lo que supone que investigan en el ambiente de las organizaciones caritativas y las personas sin hogar y los grupos neonazis que agreden a estos grupos. Delicado agrede a uno de estos 
individuos cuando le interroga y el grupo se venga de ella dándole una paliza, siguiendo la tradición de los protagonistas de la hard-boiled tradicional.

En cuanto a las relaciones personales, vemos a Petra con un psiquiatra, Ricard Crespo, que permanecerá en su vida una vez hayan roto. Garzón continúa su relación con las hermanas Enárquez y le visita su hijo, Alfonso, por segunda vez desde el inicio de la serie, para presentarle a su novio Alfred. Esto supone un golpe para Garzón, que no asume la homosexualidad de su hijo. En este caso, parece que los cambios que el subinspector sufre desde la primera entrega no le resultan suficientes cuando se trata de la homosexualidad de su hijo. Fermín siente que la orientación de su hijo cuestiona su propia masculinidad.

- Asumí en su día que la profesión de policía ya no es sagrada, que en esta época moderna debo cargar con un puto teléfono móvil y hacer mis informes en ordenador. He aceptado incluso, y usted me perdonará que ponga tanto énfasis, la igualdad absoluta de la mujer. Pero que mi hijo viva con un tío ya es demasiado para mí. Renuncio a comprender (Giménez Bartlett, 2004 [2013]: 1167).

La séptima entrega, Nido vacío (2007), supone un punto de inflexión en la vida de la inspectora. Petra deberá investigar el robo de su arma en un centro comercial. La ladrona ha sido una niña y la testigo otra menor, Marina, que lleva a Delicado a conocer a su familia: su padre Marco, arquitecto y sus hermanos (el contacto de la policía con las madres es mínimo). Delgado se siente muy atraída por Marco, que gana a Petra en divorcios (tres exmujeres).

La investigación destapará una red mafiosa rumana de trata de personas y abuso infantil que, sobre todo, afecta a mujeres y a niñas. La inspectora se sentirá muy próxima a la pequeña ladrona, sin embargo, será la conexión que entabla con Marina la que le hará cuestionarse su decisión de no haber sido madre y la dirección que tomará la relación.

Garzón también se enfrentará a una decisión que le puede cambiar la vida: mantener su independencia o aceptar casarse con Beatriz. Otra boda será la de la 
agente Yolanda con un compañero de la comisaría, el «atontolinado» de Dominguez.

El silencio de los claustros (2009) narra el asesinato de un monje restaurador de momias. El caso transcurre en un convento de monjas y serán éstas las sospechosas. Ahora Petra debe equilibrar su trabajo con una familia numerosa, pues finalmente se casó con Marco. Garzón también optó por casarse con Beatriz y debe enfrentarse a cambios importantes en su forma de vida. Su esposa es una mujer sofisticada y con poder adquisitivo que, en cierto modo, saca al subinspector del medio ambiente proletario con el que se ha identificado hasta el momento. Esto en muchos casos no es del agrado del policía, que tiene que modificar aspectos como puede ser su forma de vestir. La inspectora lo describe de la siguiente manera:

Desde que Garzón estaba casado, notaba que se habían efectuado importantes cambios en su modo de vestir. Ahora llevaba camisas y pantalones más esport, americanas ligeramente desestructuradas, había abdicado de la corbata y no había vuelto a ponerse ningún traje en la línea ortopédica que le caracterizó durante su larga viudedad. Tuve la funesta idea de comentárselo porque aquella mañana lo encontré particularmente elegante (Giménez Bartlett, 1996 [2013]: 226).

En Nadie quiere saber (2013) Delicado y Garzón se enfrentarán a un caso abierto. Un empresario, Adolfo Siguán (70 años), fue asesinado meses atrás cuando requería los servicios de una prostituta adolescente (Julieta). En su momento, se consideró al chulo como el asesino, y como fue encontrado muerto se dio por cerrado el caso, en el presente no está tan claro. Petra viaja, primero, a Ronda con la intención de entrevistar a Julieta, que ahora hace muebles a mano y vive junto a su compañero, un toxicómano recuperado. La investigación lleva a Petra y Garzón a Roma. En Italia, se encuentran con unos colegas con los que congenian, descubriendo que el «honrado» empresario tenía vínculos con la mafia. 
Todo esto resulta una nube de humo y no tiene relevancia para el caso. Siguán era un pederasta que abusó de sus tres hijas cuando eran adolescentes, hecho que les afecta a su vida de adultas.

En el terreno personal, Petra se encuentra con un comprensivo Marco y una hija e hijos no tan tolerantes con los imprevistos laborales que le surgen a Petra. Garzón parece haber descubierto cómo sobrellevar las exigencias de su nueva vida (lleva una mochila de libros sobre Roma para el viaje que le ha preparado Beatriz).

Finalmente, Crímenes que no olvidaré (2015), es una compilación de relatos. Los casos que recoge este libro nos muestran a una Petra que tiene que dejar a su familia en momentos considerados especialmente familiares como Navidad o las vacaciones de verano, lo que empieza a perjudicar su vida familiar, y surgen las primeras discusiones con Marco.

\subsection{Mercedes Castro}

Mercedes Castro completa el corpus de autoras de la tesis. Conocedora del mundo literario porque ha trabajado durante años en diversas editoriales, opta por escribir las novelas que le gustaría leer.

\subsubsection{Mercedes Castro: escritora}

Mercedes Castro (1972- ) (Imagen 11) ha trabajado como editora en diferentes departamentos del Grupo Planeta. Como autora, comenzó realizando una edición crítica sobre la obra de Pérez Galdós, seguida de la de un poemario de Rosalía de Castro. Su primera novela, Y punto (2008), fue galardonada como Mejor Ópera Prima en lengua española por el Festival de Primera Novela de Chambéry (Francia). Hasta la fecha únicamente ha escrito otro libro de género difícil de situar 
dentro de las categorías tradicionales, Mantis (2010). De hecho, Castro, que por su profesión conoce muy bien el medio editorial y su clasificación, como hemos señalado antes, es reacia a que encasillen sus obras en un género concreto porque considera que «el lector lee libros que le apetece leer y punto. Antes se colocaban por colecciones, por género, y eso cada vez ocurre menos. De hecho, hay editoriales que están renunciando a la imagen de sus colecciones. El mestizaje favorece la creación literaria» (Castro en

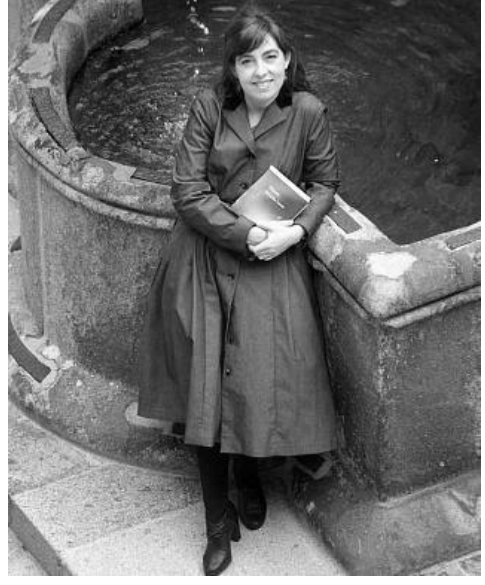

Imagen 11. Mercedes Castro Silió, 2 de febrero de 2008).

Castro es una escritora a la que le gusta jugar con las lectoras y lectores en sus novelas, de hecho cuando se le señala que las protagonistas femeninas parecen revanchistas con los hombres, llegando al asesinato en Mantis, responde: «Yo no voy de feminista radical. En realidad es todo una broma. Un juego. Me hace gracia que cuando este tipo de cosas las hacen gente como Amelie Nothomb o [Michel] Houllebecq, se ven con ironía, pero ¿y si lo hago yo?» (Castro en Corroto, 10 de abril de 2010: en línea). La autora impregna sus libros de ironía, y siempre va más allá de lo que parece.

\subsubsection{Y punto y Mantis: personajes}

Clara Deza es la protagonista de $Y$ punto (Castro, 2008) (Imagen 12). Subinspectora de policía, está rodeada de hombres machistas y le cuesta entrar en el «club de los chicos». Casada con el abogado Ramón Montero Ortega-Trevijano, sufre a una suegra clasista que no soporta que su hijo se haya casado con una mujer «inferior», una policía sin clase. Tiene un gato con el que mantiene una relación de amor-odio que interpreta los altibajos de ánimo que le provoca el día a día en su vida. También tiene que lidiar con un antiguo novio, Carlos París, la nueva estrella ascendente de la comisaría. Santi, el comisario Carahuevo, el inspector jefe Bores... Su creadora la define con los siguientes términos: 
Quería a una mujer joven en un mundo de hombres. Una mujer con celulitis, que tuviera el punto de vista femenino. Terminar con el estereotipo de la policía marimacho y con tacones. Porque muchas mujeres que trabajan en un mundo masculino se masculinizan por supervivencia. Creo, y es una reivindicación mía, que la sociedad en la que vivimos es cada vez más inhumana, borde. El fuerte pisa al débil, se falta al respeto. Y quería que ella lo viese y le minase que se cometan abusos a todas horas [...] que le permitiera llegar a muchas facetas de la sociedad y de la vida de alguien. Que entrase en apartamentos de lujo y en chabolas [...] Y Clara tenía que ser muy ingenua frente a sus compañeros muy maleados, con la sensibilidad de pensar que detrás del cadáver había una vida (Castro en Silió, 2 de febrero de 2008: en línea).

Es decir, Castro pretendía que la subinspectora Deza fuera un personaje real y coherente. Porque para la autora: «Hay mujeres que nunca aparecen en los libros, hay mujeres anónimas, bragadas, con su carga de inseguridades, valentías y bromas que siguen adelante viviendo, luchando, sin que nadie les dé voz» (Castro en García, 31 de marzo de 2016: en línea). La autora gallega quiere reflejar a las heroínas del día a día que nunca salen en los titulares:

Mujeres en trabajos de hombres que se enfrentan a su incomprensión cotidiana, mujeres que intentan conciliar vida personal y trabajo que nunca se verán reflejadas en esas heroínas de diseño, bien pagadas y mejor calzadas, carentes de responsabilidades, bebedoras de cócteles y un tanto neuróticas que protagonizan hoy por hoy infinidad de novelas. Y, sin embargo, las mujeres de las que hablo son heroínas de verdad (Castro en García, 31 de marzo de 2016: en línea).

De hecho, Castro declara que ha creado una protagonista sobre la que le gustaría escribir. Clara no es perfecta, es humana:

Estaba cansada de leer novelas en las que detectives norteamericanas, con sus medias de seda, corrían tras los malhechores encaramadas en altísimos tacones; de arquear la ceja porque a muy pocas mujeres protagonistas de novelas se las ve ir a hacer la compra, o lidiar con la suegra, o meterse en un atasco, o flaquear de vez en cuando procurando que nadie se dé cuenta, soltando borbotones de tacos para defenderse de la vida, pensando en poemas 
por dentro para consolarse, gritando para hacerse respetar, apretando los dientes para salir adelante (Castro en García, 31 de marzo de 2016: en línea).

A diferencia de otros personajes del género, sólo tenemos una aventura protagonizada por ella, con un final completamente abierto para que la lectora y el lector imaginen. La autora ha confirmado que no habrá segunda parte con Clara Deza como protagonista, pero no descarta desarrollar un spin off literario con alguno de los otros personajes.
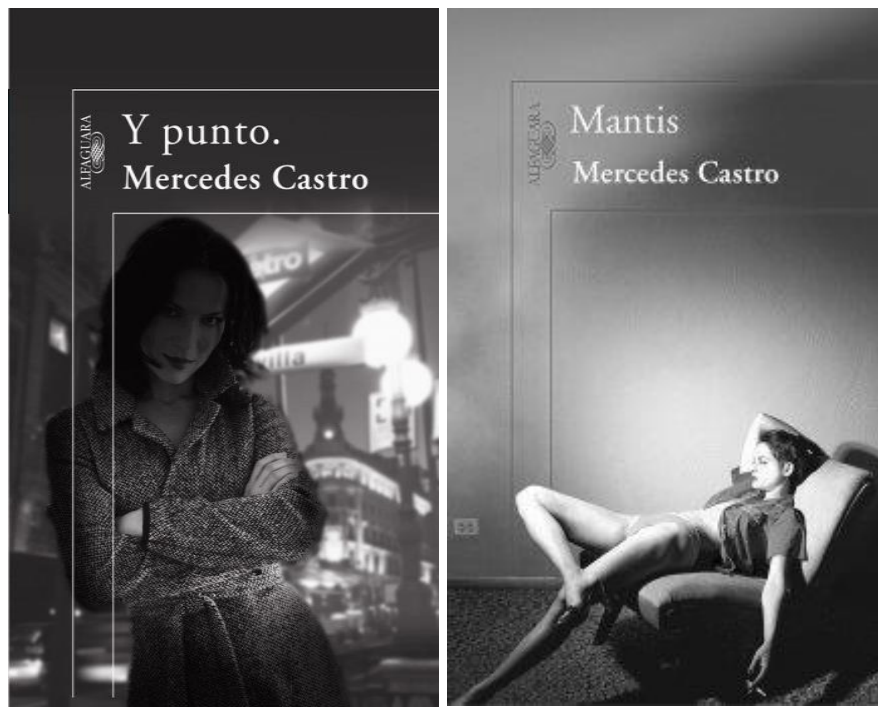

Imagen 12. Portadas de las novelas de Mercedes Castro. $Y$ punto y Mantis

Teresa Sinde ${ }^{112}$, «sin el Valverde, eso lo dejo para mamá» (Castro, 2010: 24), la protagonista de la segunda novela de Castro, Mantis (Imagen 12), es la cocinera propietaria de un restaurante (Barbantesa) de éxito y estrella de la televisión con un lado oscuro, que cuando conoce a un hombre se transforma en una femme fatale: «Soy una mujer oscura [...] malvada y cruel» (Castro, 2010: 253). Esconde un secreto relacionado con la complicada y abusiva relación que mantuvo con su madre, que, aun estando muerta, condiciona la vida de su hija. De hecho, la mayoría de las decisiones que toma Teresa están relacionadas con hacer lo contrario a lo que haría su «perfecta» progenitora. Esta insana forma de tomar decisiones es contrarrestada por los amigos de Teresa, que son su apoyo en el restaurante y en su vida.

\footnotetext{
${ }^{112}$ La mantis es un insecto de cuerpo alargado y estrecho, color verde o amarillento con patas largas, que se alimenta otros insectos, y cuya hembra devora al macho tras la cópula. También recibe el nombre de santateresa.
} 
Este personaje, según palabras de la autora en una entrevista a Europa Press, es «una burla hacia ciertos estereotipos masculinos y femeninos», pero más allá de un enfrentamiento de géneros, precisa que «en esta sociedad todos estamos jodidos y tanto las mujeres como los hombres tienen sus problemas para asumir su rol social, atemorizados por lo políticamente correcto, que nos puede a todos» (Castro en Europa Press, 16 de abril de 2010: en línea).

\subsubsection{Y punto y Mantis: sus crímenes}

La primera novela de Mercedes Castro, $Y$ punto (2008), narra el asesinato de un yonqui, una prostituta y un abogado prominente. Clara Deza se mueve entre dos mundos: el laboral y el personal, que en algunos momentos llegan a cruzarse.

Su casa es, a veces, su refugio, y, a veces, su cámara de tortura. De la misma manera que tiene encuentros sexuales plenamente satisfactorios, Ramón, su marido, se muestra en sus peleas como un tirano. Romero López (2016) analiza un episodio que sucede cuando Clara está recogiendo el agua del congelado que se ha derretido. El abogado, durante la discusión, se muestra insultante y despreciativo:

Nestas liñas obsérvase de novo esa ideoloxía patriarcal, na que a muller non serve para nada máis que para ser un obxecto contra o que o home pode descargar toda a súa rabia. Ademais, déixase ver a idea de que o home sempre ten que ser máis sufrido que a muller, traballa máis, cánsase máis, en definitiva está por riba dela. Mais esta escena remata, de novo, co home pedindo perdón polo acontecido (Romero López, 2016: 12).

Representa todas las fases de la violencia en la pareja: escalada de tensión, agresión y arrepentimiento (petición de perdón), como vemos que sucede en este caso. El control es otro tipo de violencia que sufre en su relación. A pesar de todo esto Clara dice estar muy enamorada de Ramón en diversas ocasiones. Su suegra, también manifiesta una conducta machista, considerando que Clara debería cuidar a su hijo en lugar de trabajar en un oficio tan peligroso. 0 le intenta hacer sentir culpable porque Ramón se puede preocupar al descubrir que Clara tiene un bultito 
en un pecho. Sin embargo, esta mujer tendrá también su propio autodescubrimiento.

En el trabajo le cuesta, en ocasiones, hacerse escuchar, pero presenta batalla y sigue con la investigación hasta descubrir que lo que parecía el caso de otro drogadicto muerto es, en realidad, un caso que involucra a mafias internacionales.

Es interesante observar que Clara Deza presenta características similares a Petra Delicado, es tenaz, irónica, dura... y tiene, también, una «voz propia». Sin embargo, Castro le da a su subinspectora una voz más mordaz y satírica llena de ironía. El tono de la escritora gallega es más comprometido y se involucra en la obra. Como le gusta decir a la autora, una protagonista de «carne y hueso».

Mercedes Castro define esta primera novela como «[...] negra, intimista, femenina, introspectiva y con una parte muy importante de crónica social, que siempre ha sido un elemento presente en la novela negra». Sobre sus expectativas, añade: «No pensé que fuese conocida en el mercado, y además anima el mercado ese punto de originalidad» (Castro en Silió, 2 de febrero de 2008: en línea).

La segunda novela de Mercedes Castro es completamente diferente. En Mantis (2010) la protagonista de esta novela negra no es policía, es cocinera. Teresa Sinde es una mujer apasionada y llena de complejos que se dedica a crear recetas innovadoras. Por otra parte intenta descubrir su identidad y superar sus traumas infantiles con amantes que curiosamente desaparecen tras su relación.

La violencia que ejerce Teresa Sinde consideramos que es significativo que se desarrolle en el ámbito privado, mientras en el ámbito público se presenta como una mujer de éxito.

Con los hombres entabla dos tipos de relación: sus amantes, que no sobreviven, y sus amigos, compañeros de trabajo, o Germán, un periodista que resulta ser su alma gemela. 


\subsection{Síntesis}

Este capítulo nos ha servido para presentar a las autoras y su obra. Comparativamente Alicia Giménez Bartlett tiene una larga carrera como escritora, en la que ha cultivado diversos géneros. Aunque en algún momento se la calificó de feminista, al escribir Una habitación ajena (1997), la escritora señala que en las novelas de Petra Delicado intenta crear personajes que puedan ser entendidos por un amplio público. Así, los personajes son menos abiertamente feministas. La autora reconoce que cuando escribe intenta ser más neutral.

Petra es una detective de hard-boiled con todos los atributos tradicionales de este subtipo de novela negra: dura, malhablada, tiene diferentes amantes, etc. Le acompaña Fermín Garzón, con el que se complementa perfectamente. Al tener diez entregas se puede rastrear el pensamiento de la inspectora y la evolución en éste.

Por otra parte, Mercedes Castro es una autora joven con dos novelas en el mercado. Los dos títulos son completamente diferentes. Mientras Y punto presenta la perspectiva de una policía a la que la escritora humaniza, Mantis refleja el punto de vista de una femme fatale devora-hombres. Así, Castro fuerza las normas de la novela negra para crear un producto con elementos novedosos que atrapan a la lectora y el lector.

Una vez introducidas, a grandes rasgos, las protagonistas del corpus de esta tesis, pasamos a analizar desde una perspectiva de género la representación que Giménez Bartlett y Castro hacen de las protagonistas de sus novelas. 


\section{CAPÍTULO 4. \\ CONSTRUCCIÓN DE NUEVOS MODELOS DE \\ REPRESENTACIÓN DE LAS MUJERES EN LA NOVELA NEGRA ESPAÑOLA ACTUAL DESDE UNA PERSPECTIVA DE GÉNERO}

4.1. Protagonistas femeninas en la novela negra española actual desde una perspectiva de género

4.1.1. Mujeres profesionales: Petra Delicado, Clara Deza y Teresa Sinde

4.1.2. Masculinización vs feminización en la representación de las protagonistas

4.1.3. Representación de la maternidad en Alicia Giménez Bartlett y Mercedes Castro

4.1.4. Representación de las relaciones de los personajes femeninos en Alicia Giménez Bartlett y Mercedes Castro

4.1.5. Representación de la violencia de género: de la agresión física a los micromachismos

4.1.6. Representación de la sexualidad de las protagonistas en las novelas de Alicia Giménez Bartlett y Mercedes Castro

4.2. Síntesis 



\title{
CAPÍTULO 4. Construcción de nuevos modelos de representación de las mujeres en la novela negra española actual desde una perspectiva de género
}

\author{
Escribo novela negra porque es una literatura viva, \\ que cuenta lo que nos rodea y sus personajes suelen ser gente de a pie.
}

Alicia Giménez Bartlett

Las herramientas que utilizan las escritoras son las palabras, las frases y los párrafos que crean una estructura concreta para contar una historia. En el caso de la novela negra, además, la estructura de la historia está de alguna forma establecida de antemano. El análisis que hemos realizado de diferentes títulos desde la aparición de las primeras novelas policiacas nos permite afirmar que las primeras escritoras del género aparecen casi al mismo tiempo que estas historias. Sin embargo, en este momento inicial en el que se desarrolla el subgénero enigma no hay diferencias significativas entre los personajes de las novelas escritas por mujeres y los protagonistas de las novelas escritas por varones. Como ya hemos señalado con anterioridad, Sherlock Holmes creado por Arthur Conan Doyle en 1887 y Miss Marple personaje de Agatha Christie en 1928, o Auguste Dupin que salió de la imaginación de Edgar Allan Poe en 1841 y Hercules Poirot también un personaje de Agatha Christie creado en 1920 presentan características similares en cuanto a su carácter, personalidad e historia, es decir, la estructura narrativa fijada por el género hace que las autoras y autores creen personajes y situaciones muy similares.

El objetivo de esta tesis, como ya hemos señalado en la introducción, es identificar los modelos de mujeres que aparecen en novelas negras contemporáneas, más concretamente en las escritoras de novela negra Alicia Giménez Bartlett y Mercedes Castro. Para ello realizamos un análisis crítico desde una perspectiva de género de las novelas que hemos presentado en el capítulo anterior. 


\subsection{Protagonistas femeninas de la novela negra española actual desde una perspectiva de género}

Consideraremos dos aspectos fundamentales del género negro para desarrollar nuestro análisis. Por una parte, seguimos la teoría, ya mencionada en los anteriores capítulos, de que la novela negra está atravesada por la crítica a la sociedad en la que se publica. Por otra parte, no cabe duda de que se trata de un juego con las lectoras y lectores, un género lúdico en el que las autoras y autores plantan pistas para que el público descubra la solución al problema, o se plantee una reflexión ética y moral. ¿Qué perspectiva adoptan las autoras que analizamos?

En el caso español, como hemos mencionado antes, son muy pocas las escritoras que se han decantado por las novelas negras hasta la llegada de la Transición y durante la misma. Esta situación cambia con el inicio del nuevo siglo.

El informe El sector del libro en España (2013-2015) realizado por el Ministerio de Educación, Cultura y Deportes junto al Observatorio de la Lectura y el Libros revela que

Las mujeres, con un $64,1 \%$ de lectoras en el tiempo libre, leen más que los hombres (54\%). Las diferencias afectan también al tipo de lectura: las mujeres leen más libros y revistas, mientras los hombres se decantan más por la prensa, los cómics y las webs, blogs y foros. Además, las mujeres leen más por entretenimiento $(88,3 \%)$ que los hombres $(78,9 \%)$, aunque esta es la principal razón para leer con independencia de factores como el sexo o la edad. La principal razón para no leer entre los no lectores o los lectores ocasionales es la falta de tiempo (Ministro de Educación, Cultura y Deporte y Observatorio de la lectura y el libro, abril 2015: 62).

Este tipo de informes dictan las políticas de edición de las editoriales que ven en las mujeres un público objetivo que atraer hacia sus publicaciones. Por ello, buscan estrategias varias, entre ellas: publicar novelas de una temática con la que se sientan identificadas y publicar novelas escritas por mujeres buscando también la identificación con éstas. Así, en los últimos años, a las escritoras extranjeras clásicas y contemporáneas se les unen autoras que desarrollan sus personajes 
desde esta nueva perspectiva, una de las más importantes es sin duda Alicia Giménez Bartlett y su serie de Petra Delicado (primera entrega, Ritos de muerte, 1996, siendo la última el compendio de relatos Crímenes que no olvidaré, 2015). Otra de las escritoras, Mercedes Castro, sacude el mundo editorial de la novela negra con un relato lleno de ironía e inconformismo.

En la mayoría de los casos, estas autoras trabajan con las pautas de la novela negra clásica aunque con cierta laxitud y revisando el género desde su propia perspectiva, incluyendo detectives lesbianas, inspectoras divorciadas, con una familia, etc., es decir, reflejan y ficcionalizan la sociedad en la que escriben. Delicado es una policía nacional en un momento en que las mujeres se están incorporando al cuerpo con los problemas que esto supone. A pesar de que Bartlett no denuncia abiertamente la situación de las mujeres, sí lo plantea como una cuestión más que supera su personaje, ella misma afirma que escogió el género negro porque le «permitía escribir según mi modo de pensar. Soy observador y me gusta añadir elementos de crítica social, pero como escribir novela social hoy en día es pecado, lo suplo con la negra» (Olbiols en Martín Alegre, 2002: 416). Así, aunque de manera explícita no hace una declaración feminista, «La elección de una investigadora femenina es en sí un comentario sobre un tema social tan candente como a la situación de la mujer» (Martín Alegre, 2002: 416), lo que de hecho podemos entender como una reivindicación sobre la situación de desigualdad de las mujeres. Una postura diferente adopta Castro en $Y$ punto (2008), dibujando a una Clara Deza que debe luchar contra «los elementos» humanos y naturales para salir adelante como policía. En este caso se trata de una novela que no tiene continuación, no es parte de una serie, al contrario de Delicado, que evoluciona e involuciona en cada nueva entrega.

Teresa Sinde se sitúa frente a estos personajes. Es una femme fatale, ¿la mala de la historia?, ¿la criminal? Su actitud ante la vida es diametralmente opuesta a la de Petra y Clara, no se ajusta a los convencionalismos. Aunque parezca lo contrario, vive en los márgenes de la sociedad.

A pesar de las diferencias hay un elemento que une a las tres protagonistas. Como cualquier otro personaje de novela negra, la policía o los detectives circulan y conectan las clases sociales más desfavorecidas y las clases sociales que 
representan el poder político, económico, social, es decir, la élite social. Éste es un elemento a tener en cuenta en nuestro análisis: tanto la policía (bien en Barcelona, Petra Delicado, bien en Madrid, Clara Deza) como la asesina, cocinera, show-woman (Teresa Sinde), pertenecen a una clase social acomodada de la que reniegan. Esto las sitúa en una situación privilegiada para el desarrollo de sus actividades profesionales, pero también para tomar decisiones que no siempre se ajustan a las expectativas sociales que se tienen sobre ellas.

Hemos mencionado con anterioridad el discurso social del subinspector Garzón. Así, en Ritos de muerte (1996 [2013]: 37) el análisis preliminar de las violaciones que hace Petra es que parecían «muchachas frágiles», a lo que Garzón añade: «—Y la clase social — dijo Garzón varios días después-. Las dos eran chicas trabajadoras, de escasos recursos familiares, sin cualificación profesional». Esta teoría queda desbaratada con la cuarta agresión: «La nueva hazaña del violador desbarataba las conjeturas sociales que había hecho Garzón. En esta ocasión se trataba de una niña bien. El hecho se había producido al atardecer en la parte alta de la ciudad, en un barrio elegante» (Giménez Bartlett, 1996 [2013]: 72).

Sin embargo, la teoría social de Garzón continúa y diserta sobre la diferencia que existe entre las clases sociales populares y pudientes, al comprobar cómo reacciona la familia y la víctima rica del violador. La decisión que toman es intentar «borrar» la agresión, así que mientras está en el hospital la operan para quietarle la marca que les deja el agresor y después la mandarán a estudiar fuera, cualquier pregunta tendrán que hacerla al abogado de la familia y/o al padre de la chica.

- Siempre pasa igual, las clases populares resisten mejor los contratiempos. Me lo comentaba el forense de Salamanca una vez. Si en una familia acomodada nace un hijo subnormal la cosa se convierte en un drama, una tragedia, un motivo de ocultación. Pero si se trata de una casa sencilla de trabajadores, entonces el niño enseguida es aceptado, lo llevan limpio, lo cuidan, se lo enseñan a todo el mundo para que vean que es cariñoso y hasta guapo (Giménez Bartlett, 1996 [2013]: 76). 
Garzón, un hombre callado y discreto, cuando habla de los conflictos de clase toma posiciones muy claras. Petra lo nota pronto: «¡Coño con Garzón!, era lo más largo que me había dicho desde el día en que nos conocimos. El tema de la lucha de clases parecía el único capaz de desatar su pasión y locuacidad» (Giménez Bartlett, 1996 [2013]: 76).

El entorno de Petra, que la conocía antes de ser policía, no siempre está de acuerdo o entiende su nueva decisión profesional, entre otras cuestiones porque les puede afectar. Hugo, su exmarido, un abogado de éxito, que se va a casar con la mujer adecuada113, le advierte: «Andar todo el día junto a un policía gordo, entrando y saliendo de bares de mala muerte y puticlubs. Te estás jugando tu dignidad» (Giménez Bartlett, 1996 [2013]: 70). Aunque este comentario estaba, en esta ocasión, no tanto destinado a criticar «el envilecimiento que supone vivir en ambientes policiales» (Giménez Bartlett, 1996 [2013]: 22), como solía ocurrir en sus encuentros, como que tenía miedo que los relacionaran y él se viera humillado por la situación.

Ignacio Lucena Pastor, la víctima de Días de perros (1997 [2013]), no le importaba a nadie. De hecho, Petra recuerda:

Casi tuvimos que implorar para que alguna agencia de prensa aceptara la noticia de la muerte de Lucena. Naturalmente aquel caso carecía de lucimiento periodístico. No había morbo sexual, ni implicaciones políticas o raciales... nada que fuera vendible. Al fin y al cabo, ¿a quién le importaba que un lumpen desconocido muriera de una paliza? (Giménez Bartlett, 1997 [2013]: 262).

La reconstrucción de los pasos del «pobre diablo» les muestra que sobrevivía como podía entre artesanos que vendían esculturas de escayola en el mercadillo, catedráticos en Medicina que compraban perros con los que experimentar en la facultad, ayudantes de la perrera que facilitaban los animales, etc. La inspectora deduce que los perros que vendía de la perrera (que iban a acabar muertos de todas maneras, por lo que les confiesa el mozo de la perrera) valían tan poco como Lucena, eran considerados basura.

113 Es abogada y dice Hugo: «Ella no se hará policía, te lo aseguro» (Giménez Bartlett, 1996 [2013]: 22). 
En la tercera entrega, los conflictos de clase los representan los López, a pesar de lo cual «no eran el final de la escalera; debajo de ellos existían varios peldaños que bajaban hasta un abismo total» (Giménez Bartlett, 1999 [2013]: 492). Petra piensa que a la madre de esta familia numerosa no le importa demasiado su hijo (víctima). Las condiciones sociales de las mujeres solas y con cargas familiares suelen ser peores en términos estadísticos generales, como demuestran diversos estudios de organismos públicos como Emakunde o Unicef. Existe, por ello, una reivindicación del colectivo feminista para que a estas madres se les faciliten ayudas sociales (crematísticas o en forma de ayuda: plazas en guarderías públicas, libros gratuitos, entre otras). Sin embargo, la conciencia social de la pareja argumenta nuevamente que las personas de clases desfavorecidas sobreviven de otra manera:

La realidad de la gente pobre no tiene los mismos esquemas que la nuestra, inspectora. La señora López ama a sus hijos, pero de una manera inconsciente procura sentir lo menos posible. ¿Por qué querría llevar a fondo sus sentimientos si resulta que casi siempre son dolorosos? (Giménez Bartlett, 1999 [2013]: 493).

Durante la investigación de este tercer caso, Mensajeros de la oscuridad (1999 [2013]), a Petra le afecta la visita a los albergues sociales en busca de información sobre quienes pueden ser los responsables de enviarle los penes amputados.

El espectáculo de la marginación me resultó atroz. Los detalles de lo visto me golpeaban la mente sin cesar. Aquel equipamiento de los albergues, con camas idénticas y mantas bastas, los pequeños intentos de decoración consistentes en flores de plástico y cuadritos con fotos de paisajes idílicos eran significativos en sí. Todo hacía pensar en hombres derrotados que tienen como espejo una sociedad próspera, el excipiente, los que no cuentan, los que casi no son. (Giménez Bartlett, 1999 [2013]: 493).

Petra invita a Garzón a cenar a su casa, pero no se le va de la cabeza la situación de esas personas que ha visto en el albergue, lo deprimente que le resulta y reflexiona: «Todos nos vamos librando, ¿verdad, Fermín? Trabajamos y nos libramos de la pobreza, tenemos amigos y nos libramos de la soledad... Nos vamos 
escapando, nos escabullimos..., pero si un día falla algo podemos acabar ahí, en uno de esos hoyos que hemos visto». (Giménez Bartlett, 1999 [2013]: 494)

El subinspector la anima, le dice que no les puede pasar y Petra se defiende ante estos sentimientos: «Sabe que no soy una persona blanda, que como policía voy acostumbrándome a lo peor; pero esto es distinto, aquí no hay delito ni lucha, ni siquiera picaresca» (Giménez Bartlett, 1999 [2013]: 494).

En esta ocasión será la inspectora quien realice un comprometido comentario social: «Son hombres acabados, apartados en un rincón y olvidados; pero lo cojonudo es que todos lo sabemos y nos da igual» (Giménez Bartlett, 1999 [2013]: 494). Garzón le responde que en lugar de quejarse pase a la acción, pero Petra confiesa que no aguantaría ver ese tipo de injusticia todos los días. Finalmente, el subinspector le levanta el ánimo cantando una coplilla popular.

Es curioso que Giménez Bartlett coloque en esta situación únicamente a varones. ¿Las mujeres no participan de este descenso a los infiernos? El planteamiento de la pobreza femenina se representa a través de otras figuras, como hemos visto que sucede con la familia López.

Al tiempo que avanza la serie, la inmovilidad de las clases sociales se hace más evidente. En Muertos de papel (2000), Petra tiene que lidiar no sólo con la clase social acomodada como en títulos anteriores sino que además son personajes que se agarran desesperadamente a esa clase de apariencias (mundo rosa). Una de las testigos que tiene un marido muy celoso, y que cree estar en un lío por hablar con la pareja de investigadores, afirma, cuando Petra le propone que le diga que eran amigas de su «etapa anterior»: «¿De verdad? Usted sabe perfectamente que nadie se tragaría eso. Está claro que usted y yo nunca podríamos haber sido amigas, no somos de la misma clase social, y eso se nota en todo. Le aseguro que ésa es una lección que sí he aprendido, inspectora» (Giménez Bartlett, 2000 [2013]: 776). 
Por otra parte, en Serpientes en el paraíso (2002 [2013]: 1046) nos encontramos con la situación que vive parte de la población inmigrante ${ }^{114}$. En concreto mujeres inmigrantes que trabajan en tareas domésticas de forma precaria: jornadas agotadoras cuidando a las niñas y niños de la familia por un pequeño sueldo y con la posibilidad de ser despedidas en cualquier momento. Aun así, estas mujeres habían conseguido crear su propio ecosistema con un particular sistema de poder:

Sin duda, las criadas tenían su propio mundo paralelo en «El Paradís». Eran amigas, se comunicaban, libraban sus luchas de preponderancia o poder según la nacionalidad y se hacían confidencias sobre las familias para las que les había tocado trabajar. Me habría encantado meter la nariz allí (Giménez Bartlett, 2002 [2013]: 957).

La pérdida de su Glock ${ }^{115}$ centra las pesquisas que se desarrollan en Nido vacío (2007 [2013]: 1379). En este caso, la miseria también está aparejada a la inmigración. Si bien en la anterior entrega se centra en las mujeres que trabajan en casas de urbanizaciones de lujo realizando tareas domésticas, en esta ocasión, la realidad a la que se enfrenta es más dura y también está representada por mujeres. Por un lado, las inmigrantes del Este explotadas en talleres de confección y por otra la trata de personas (niñas). Al comienzo de las pesquisas, todo apunta a que la ladrona ha sido una «niña de la calle». Menores inmigrantes ilegales que no

114 Alicia Giménez Bartlett introduce el proceso extraordinario de regularización de inmigrantes que acometió el Gobierno de José María Aznar en 2000. Petra le pregunta al inspector Morales por la situación de una de las criadas de la urbanización. Morales indica que la «chica está limpia. Hace cinco años se registró en el censo de inmigrantes con contrato [...] Oye, se hizo tabla rasa con los inmigrantes cuando se les dio la oportunidad de legalizarse en el país. Con que aportaran un contrato laboral ya era suficiente» (Giménez Bartlett, 2002 [2013]: 982).

115 La Glock ha sido el arma oficial de la policía durante mucho tiempo. Petra se decanta por una Glock modelo 22. Otras agentes, como Dolores Redondo, prefieren una Glock 19. Y este aspecto es relevante, ya que como señala Shelley Godsland (2007: 56-57), para el caso de Petra, y que es extensible a otras detectives armadas, la Glock se convierte en una referencia al pene. De esta manera, se masculinizan estos personajes femeninos y en cierto modo se invierten los roles de género como se puede deducir de la fantasía que Petra tiene al imaginarse desenfundando el arma frente a Ricard Crespo, un psiquiatra que también será su amante un tiempo, en Un barco cargado de arroz (Giménez Bartlett, 2004 [2013]: 1153). 
tienen aparentemente familia porque les han abandonado aquí o han llegado solas y solos como polizones.

Petra reconoce que el caso del robo de su arma, que es más complejo de lo que pensaba en un principio, le está afectando, no por el robo en sí, sino porque descubren una red de pornografía infantil: «Aquel caso me afectaba sobremanera por una sola razón: había visto la cara del mal. En mi labor de policía había tenido que enfrentarme con el crimen, pero nunca había tratado ni de lejos ningún tema relacionado con el abuso de menores» (Giménez Bartlett, 2007 [2013]: 1438). Como policía había visto muchas veces cómo se aprovechaban de los más débiles, pero el abuso a niñas y niños era algo atroz porque se les clavaba en el alma un daño cuando todavía no había dado «cuatro pasos en el mundo».

Petra reflexiona a la vista de las pistas que le deja el caso sobre los abusos a los que quedan expuestos las y los inmigrantes: «Desde que las mafias extranjeras y la inmigración ilegal están a la orden del día en España, identificar a alguien se ha convertido en una tarea complicada. Corre por la calle mucha gente sin nombre» (Giménez Bartlett, 2007 [2013]: 1426).

La dignidad que muestran estas personas es significativa y Petra puede observarla cuando una de las mujeres de la fábrica (Illiana Illiescu) va a declarar que en la fábrica le enseñaron «fotos malas de niños» y le propusieron ganar mucho dinero si dejaba que le hicieran algunas a su hijo (Giménez Bartlett: 2007 [2013]: 1466-1468). Al finalizar el interrogatorio, Petra, en un intento, quizás torpe, de agradecimiento, tal vez para acallar un poco su conciencia, le da treinta euros que llevaba en el bolsillo. La costurera en un primer momento los rechaza: «Yo viene aquí porque foto muy mala, muy mala, no porque euros» (Giménez Bartlett, 2007 [2013]: 1469).

Garzón empatiza con estas mujeres que vienen al país pensando en encontrar una vida mejor y acaban cosiendo sujetadores de manera insalubre todo el día, como reflexiona al saber que el marido de Illiana ha estado esperándola para que no volviera a casa sola: «-El marido la esperaba en la calle para que no fuera sola. — ¿Ha estado dos horas esperándola sin saber cuándo regresaría? —Ya lo ve. Esa 
gente no cree tener ningún derecho, no pide nada, lo aguanta todo» (Giménez Bartlett, 2007 [2013]: 1470).

Todos estos ejemplos de la situación de la inmigración que afloran en las diferentes investigaciones (empleadas del hogar filipinas explotadas, mujeres del Este prostituidas y hombres empleados como matones, mujeres inmigrantes en talleres de costura trabajando a destajo, etc.) describen conflictos sociales actuales. Giménez Bartlett, sin embargo, los presentará con mayor contundencia, si cabe, en Un barco cargado de arroz (2004). Tomás «El Sabio» era un vagabundo que trabajaba de contable para una organización benéfica y es asesinado cuando quiere denunciar un timo. Petra y Garzón se sumergen, de la mano de Yolanda Santos, en un mundo de pobreza extrema donde conviven «inmigrantes sin papeles, y jóvenes drogadictos, gente sin trabajo... un poco de todo» (Giménez Bartlett, 2004 [2013]: 1145).

Giménez Bartlett pone en boca de la agente de la policía local una descripción próxima a la realidad de las personas sin hogar. La imagen que ofrece de la situación de los vagabundos es la siguiente ${ }^{116}$ :

Mendigan, tocan instrumentos en la calle, reciben algunas pequeñas cantidades de la beneficencia. Con poco pasan, especialmente los homeless. Son los que suelen ir más asiduamente a los comedores de caridad, y una vez comidos... sus necesidades son pequeñas. No tienen esposa ni hijos... se limitan a vegetar (Giménez Bartlett, 2004 [2013]: 1148-1149).

En este caso, observamos que, a pesar de la difícil situación que viven, hay escalones, como señalaba Petra en volúmenes anteriores: inmigrantes pobres con

116 El Instituto Nacional de Estadística (INE) realiza periódicamente una encuesta sobre condiciones de vida. La «Encuesta sobre las personas sin hogar (EPSH 2005)» señala que el $82,7 \%$ de personas sin hogar eran hombres y el 17,3\% mujeres; el 46\% tienen hijas y/o hijos (sólo una décima parte viven con ellos). El porcentaje de la encuesta de 2012 el número de hombres sin hogar prácticamente se mantiene, 80,3\%. Sin embargo, la salud de las mujeres que viven en la calle es peor. Suelen ser personas solitarias (solteros, divorciados, viudos), alrededor de un 48,6\% viven con sus parejas. Estos datos apuntan al hecho de que las mujeres concretizan de manera diferente las situaciones de empobrecimiento en las que se pueden encontrar. 
trabajo e inmigrantes pobres que sobreviven entre mendigos y drogadictos por no tener papeles y que vivían en la calle como personas sin hogar.

Petra se sorprende de la respuesta que reciben de estas personas: «Las reacciones no eran demasiado variadas: miedo, incomprensión, indiferencia y extrañeza. Ninguno de ellos mostró violencia o indignación porque nos metiéramos hasta el centro de su precaria intimidad; habían perdido cualquier capacidad de rebeldía» (Giménez Bartlett, 2004 [2013]: 1148). Y observa que parecían de «una raza diferente» considerando que tal vez estuvieran mejor en el albergue. A lo que Yolanda les responde que no pueden estar más de quince días para no convertirse en «crónicos». La elocuente exclamación de Garzón resume lo que piensan ante esta paradoja: «iCojonudo!». La respuesta al problema que ahonda más, si cabe, en la indignación de los protagonistas es que si se encuentran a la policía urbana les pueden buscar ayuda en Servicios Sociales o el Ayuntamiento les paga el billete para irse a otra ciudad.

Nuevamente vemos que se establece un sistema jerárquico en este mundo marginal, así Petra describe:

En aquellas visitas comprobamos que, de entre los más desfavorecidos, los homeless eran el último estadio de la clasificación. En los jóvenes inmigrantes sin papeles palpitaba una esperanza de trabajo, de aceptación social, pero los viejos mendigos alcoholizados no parecían aspirar a nada, eran el final de la saga ciudadana e incluso daba la impresión, por lo que contaban las trabajadoras sociales, de que despreciaban la caridad (Giménez Bartlett, 2004 [2013]: 1164).

Este ambiente contrasta con la vida tranquila de clase media que Petra desea llevar desde el principio de la serie cuando se muda a su casa de Poble Nou o esa vida de soltero que le apetece experimentar a Garzón después de estar media vida casado en una convivencia de estricta cordialidad. Sin olvidar que ambos contraen matrimonio con dos personas de clase alta: la esposa de Garzón, Beatriz, pertenece a la familia Enárquez, una familia que forma parte de la aristocracia catalana; el marido de Petra es un arquitecto de éxito. Ambos se encuentran como pez fuera del agua en esta nueva vida, en El silencio de los claustros (2009). Petra se tiene que acostumbra a vivir con un nuevo marido, comprensivo, pero que exige cierta 
atención, por no hablar de la hija y los hijos de éste que quieren su cuota de interés por parte de la policía. Fermín, el paladín de las clases sociales menos favorecidas, debe acostumbrarse a la burguesa vida que le supone estar casado con una mujer rica, algo que parece han conseguido, con altibajos, en la última entrega, Nadie quiere saber (2009).

Clara Deza, la policía de Mercedes Castro, vive una situación similar en Madrid. La investigación lleva a la subinspectora a los peores lugares de la ciudad donde se trapichea con drogas y se ejerce la prostitución. La escritora sitúa la acción de su novela en la capital de España y, sin nombrarlo, nos describe la Cañada Real Galiana, un poblado chabolista conocido como el supermercado de la droga (Castro, 2008 [2010]: 267). Este ambiente contrasta con el barrio de Salamanca, donde el marido de Clara tiene el bufete, una de las zonas más ricas de la capital de España. De hecho su suegra, Esmeralda, es «una de las descendientes de una rancia estirpe de damas andaluzas de las de puesta de largo y peineta en los toros y palco en el teatro» (Castro, 2008 [2010]: 198).

Una zona rica de Madrid que se ve conectada con los ambientes marginales de la droga y la prostitución por la tarjeta de visita de un abogado especializado en sucesiones que se define a sí mismo como «putero». Es decir, la relación que se establece entre ambos ámbitos se cimienta en las fantasías y perversidades de estos prohombres de clase alta que encuentran en la compañía de profesionales discretas, según confiesa el abogado Roberto Butragueño: «un bálsamo, además de placer proporcionaba paz, tranquilidad y, sobre todo, comprensión. Podía hablar con ella, sentía la necesidad de volver a verla cada cierto tiempo, sin importar su tarifa y no más de una vez al mes dado lo solicitada que estaba» (Castro, 2008 [2010]: 238). Petra Delicado investiga un caso simular en Nadie quiere saber (2009), un respetado hombre de negocios paga a prostitutas menores de edad. Ahondaremos más sobre este punto al tratar el tema de la violencia de género.

La inmigración también aparece en la novela de Castro (2008), aunque no se presenta un posicionamiento crítico tan claro como en la obra de Giménez Bartlett. Un hombre que quiere denunciar el robo de su cartera se siente agraviado. 
[...] que se hayan reído de mí, que me toreen, que me tomen por tonto y me insulten. [...] Y todo por una cartera, la mía, que me la han robado. Y no la he perdido [...] no puede asegurar que fueran dos rumanos, no se pase de listillo, que eso es acusar en falso, hace falta ser racista, coño, ¿o no sabe que hay muchos más ladrones de guante blanco con negocios como el suyo que pobres inmigrantes que no se meten con nadie? (Castro, 2008 [2010]: 336).

Pero el denunciante sigue con si indignación porque en el bar le habían comentado que no era la primera vez que los dos tipos que mencionaba habían causado problemas. Continúa:

Me llamaron ladrón y racista porque mencioné a dos jóvenes de Europa del Este muy mal vestidos que se sentaron detrás de mí en la barra y que me comentaron los del bar luego, cuando me vieron tan nervioso tras el robo, que más de una vez los habían tenido que expulsar por meter la mano en los bolsos de las señoras o en las chaquetas de los maridos despistados (Castro, 2008 [2010]: 336).

En este sentido, Teresa Sinde, la protagonista de Mantis (2010), no deambula por lugares geográfica y económicamente marginales. La marginalidad de Teresa está en su interior y en las «fantasías oscuras» que tiene.

Las tres protagonistas, sí tienen en común su rebeldía y su inconformismo. Incluso Teresa Sinde adopta una posición crítica ante la sociedad que vemos en los diferentes aspectos que analizamos en esta tesis.

La metodología que empleamos para el análisis de los elementos diferenciadores de estas autoras o elementos homogeneizadores del género consiste en un análisis crítico basado en el estudio de las siguientes facetas:

Una de las cuestiones que planteamos analizar es la representación de la profesionalidad de las protagonistas en un mundo de hombres. Los feminismos plantean la apropiación de los espacios públicos como una necesidad para conseguir la igualdad entre mujeres y hombres. ¿Pero qué sucede en el espacio privado? 
Otro elemento de análisis relacionado con la salida al espacio público es la duda que se plantea sobre cómo se ocupa ese ámbito. Se asimilan las conductas dominantes masculinizadas o se intentan incorporar los valores que se les han asignado a las mujeres en el espacio privado. ¿Cómo se posicionan en estos espacios los personajes femeninos protagonistas de la novela negra española escrita por mujeres?

El patriarcado asigna a las mujeres una función de reproducción biológica y social. La maternidad se convierte así en excusa y causa para mantener controladas a las mujeres y en el espacio privado para sostener el uso del espacio público de los varones. ¿Las protagonistas se enfrentan a este tema de la misma manera o de una forma distinta a la que se espera de ellas?

La reclusión en el hogar supone un hándicap para que las mujeres establezcan relaciones entre ellas. La falta de redes entre mujeres ayuda al patriarcado a mantener el control sobre éstas para que continúen vigilando la reproducción social, que paradójicamente las sitúa en una posición de desigualdad que se permanentiza. Las protagonistas de Giménez Bartlett y Castro, ¿cómo afrontan estas relaciones?

La violencia que se ejerce sobre las mujeres para mantener el status quo se puede entender de dos formas: una hace referencia a la amenaza o la agresión física; la otra a la violencia estructural del propio sistema y las exigencias que recaen sobre las mujeres. Como policías Delicado y Deza se encuentran con la primera en su trabajo. Mientras, los tres personajes, incluida Teresa Sinde, deben enfrentarse a la segunda.

Finalmente, estudiaremos como las autoras representan la sexualidad de las protagonistas teniendo en cuenta que las sociedades patriarcales reprimen a las mujeres sexualmente cuando los detectives suelen tener parejas sexuales variadas. 


\subsubsection{Mujeres profesionales: Petra Delicado, Clara Deza y Teresa Sinde}

Las sociedades patriarcales establecen un contrato social por el que las mujeres y los hombres ocupan diferentes espacios (privado y público) de producción y reproducción, siendo el primero sostenido por el segundo, como señala Juncal Caballero Guiral (2012: 68):

La separación público-privado no es una separación natural. Al diferenciar tan claramente dos espacios, damos prioridad a uno sobre el otro. Las necesidades básicas van a ser cubiertas, puesto que no debe cubrirlas para él y para quienes le rodean, puede dedicarse al ámbito público -economía, política, sociedad, etc.- y su vitalidad se centra en la obtención del bienestar, en la consecución de la libertad y la felicidad.

Así pues, vemos cómo la reclusión de las mujeres en el espacio privado, doméstico, da libertad a los varones para desarrollar su actividad en el espacio público, generalmente un espacio de producción (trabajo) y prestigio. En cuanto a las mujeres

[...] podemos observar que, si bien [son] libre[s], las mujeres no se encuentran en un plano de igualdad con el varón, puesto que se les sigue asociando al ámbito de la domesticidad, del hogar. Esa condición de domesticidad de la mujer es la que posibilita al varón a acceder al ámbito privado como propio y, en cambio, al ámbito público como lo social (Caballero Guiral, 2012: 69).

Situar a las mujeres en la esfera privada las limita para acceder a la esfera pública, y, a aquellas que consiguen llegar «se las va a marcar con el estigma de la no feminidad. Desacreditación de las mujeres al fracasar en el proyecto de ser familiar, ser abnegado, ser conciliador, etc.» (Caballero Guiral, 2012: 69).

La naturalización de la biología femenina convierte a las mujeres en inadecuadas para el ámbito público. Este prejuicio perdura hasta nuestros días, sobre todo para desvelar los estereotipos asignados a los sexos. De hecho, la ocupación del espacio público por parte de las mujeres es un camino sin vuelta atrás. El siguiente paso para conseguir la igualdad real pasa por conseguir que los hombres ocupen el espacio privado como ámbito en el que se desarrolla un trabajo 
que permite la participación en el espacio público (reducir la doble jornada para las mujeres) ${ }^{117}$.

La incorporación de las mujeres al mercado laboral, de manera efectiva, se ha realizado en España en fechas muy tardías. Un sistema político nacionalcatólico que rigió hasta $1978{ }^{118}$ provocó un retraso en aspectos políticos, así como sociales, culturales y económicos.

Siguiendo esta realidad, como ya hemos mencionado, todas las protagonistas de las novelas negras son profesionales: Petra Delicado es inspectora de policía (antes abogada) como Clara Deza, Teresa Sinde es cocinera, productora de televisión... En otras novelas contemporáneas sucede lo mismo. Amaia Salazar es inspectora de la Policía Foral, Ada Levy es periodista, aunque trabaje como camarera y detective después del que ella siempre llama «incidente», Mariana de Marco es jueza... por poner unos ejemplos ${ }^{119}$.

${ }^{117}$ El informe de la OCDE (Organización para la Cooperación y el Desarrollo) de 2016 indica que en España las mujeres dedican un total de cuatro horas y media al trabajo no remunerado en el hogar, mientras que los hombres sólo utilizan dos horas y media de su tiempo en la misma tarea. En el resto de países miembros de la OCDE (más de 120) también se produce este desequilibro. Por ejemplo: en China, las mujeres trabajan cuatro horas en casa, por una y media de los hombres; en EEUU, la diferencia es de cuatro a dos y media, también son las mujeres las que más se dedican a las tareas del hogar; en India, uno de los países con más desequilibrio, son 6 horas para las mujeres y una para los hombres; Irlanda, cinco frente a dos y media; en México seis y cuarto frente a dos, y en Noruega, uno de los países más igualitarios, tres horas y media de trabajo no remunerado de las mujeres frente a dos y media de los hombres.

118 Tomamos como referencia la fecha de 1978 porque es el año en que se aprobó la Constitución Española y se puede empezar a hablar de un cambio político real e irreversible de la dictadura a la democracia.

${ }^{119}$ En el mundo audiovisual y en concreto en las series de televisión norteamericanas se sigue este ejemplo de colocar protagonistas profesionales: Bones (2005-2017) con una forense hiperprofesional a la cabeza del equipo forense-investigador. A la protagonista, la doctora Temperance Brenan, se le añaden otras mujeres igual de capaces como la doctora Camille Saroyan, jefa del laboratorio forense del Instituto Jefersonian, Angela Montenegro, que es una artista que realiza reconstrucciones forenses y es capaz de crear una máquina que ayuda a este fin con un complejo algoritmo. A este núcleo central hay que sumarle diferentes becarias igual de inteligentes que sus jefas. La maternidad y el sexo son dos realidades en las «vidas» de estas mujeres, que las desarrollan incluyéndolas de manera efectiva en sus vidas profesionales. Rizzoli \& Isles (2010-2016) está protagonizada por una detective y la jefe médica forense de la ciudad de Boston. Las protagonistas de las series españolas son un poco diferentes $\mathrm{y}$, aunque profesionales, se las representa como profesionales distantes o desbordadas por la realidad de sus vidas personales. Quizás estas diferencias en la representación de los personajes femeninos protagonistas se deban a la evolución sociocultural distinta en Estados Unidos y en España y el tiempo que hace 
Es evidente que la incorporación de las mujeres al espacio público es un proceso sin retorno, como queda patente de manera implícita en los textos seleccionados. Un aspecto interesante que puede explicar la creación de estos personajes profesionales e independientes pudiera encontrarse en que todas las autoras son universitarias y han trabajado en un ámbito profesional. De hecho, las diferencias que encontramos entre las protagonistas consideramos que tienen que ver, precisamente, con esta realidad de las autoras. Giménez Bartlett es la que escribe desde hace más tiempo y Petra Delicado «padece» el efecto de la edad y la estructura policial con la que convive. Sara Martín Alegre (2002: 415) señala que «las novelas de Bartlett sugieren que la mujer policía es, ante todo, una persona y no una figura representativa del feminismo o la feminidad». No obstante, Petra es un personaje al servicio de la historia, en la mayoría de las ocasiones.

De hecho, Petra adopta una postura típica de detective de la hard-boiled y como tal en algunas ocasiones adopta una actitud violenta para conseguir justicia. Ya en la primera entrega, la inspectora intimida a un detenido en un interrogatorio y le obliga a desnudarse.

Me levanté, fui hasta la puerta, pasé el pestillo. El chico me miraba nervioso. Me acerqué a él y con una furia ralentizada que me hacía tener mucha fuerza lo cogí por la solapa de la camisa y tiré hacia mí.

que las mujeres hayan adquirido sus derechos. Los misterios de Laura (2009-2011) se centran en Laura Lebrel, una inspectora del cuerpo nacional de policía que prefiere «dejarse guiar por su olfato e intuición que por las pruebas científicas» (Fernández, 25 de abril de 2011: en línea). Su vida familiar, en ocasiones, se interpone en las investigaciones que lleva, su exmarido es su jefe y tiene unos gemelos hiperactivos que se meten en líos constantemente. Esto hace que sea un personaje entrañable y no sea su profesionalidad, se trata de una protagonista que sigue más la tradición de la serie de los ochenta y principios de los noventa, Se ha escrito un crimen (Murder, She Wrote, 1984-1996), centrada en la escritora de novelas de misterio Angela Fletcher. Por otra parte, la característica gabardina que siempre lleva Laura nos recuerda a Colombo (1968-2003), la longeva serie norteamericana que duró más de cincuenta años. Es decir, se sitúa dentro de un imaginario humorístico y menos profesional: no puede identificarse porque los gemelos le han cogido la placa, coge una sartén para enfrentarse a un «intruso» que ha entrado por la noche en su casa, lleva el revólver en un enorme bolso que parece un cajón desastre apto para cualquier emergencia, entre otras situaciones absurdas. Consideramos que Laura es ama de casa, pero también es profesional, aunque parezca que ambas facetas, en ocasiones, son incompatibles, la inspectora sabe cómo manejar las diferentes situaciones, crea un orden caótico donde cuidar de su familia al mismo tiempo que realiza su trabajo de policía. 
-Si no te desnudas ahora mismo te juro por Dios que te hinchamos a hostias. Ésa es la ley.

Cedió. [...] Se quedó en ropa interior.

—Los calzoncillos también, y ponte de pie (Giménez Bartlett, 1996 [2013]: $56)$.

En Un barco cargado de arroz (2004) sucede un episodio similar. Petra no se puede controlar durante un interrogatorio y golpea al skin con el que está hablando. Esta vez, al igual que le sucede a los detectives masculinos, la banda de neonazis se venga y le da una paliza.

— No me imaginaba que eras una tía, yo creí que los jefes de la policía...

No le dejé acabar, le descargué el dorso de la mano en la cara con toda mi fuerza. Se replegó como un gato, sus ojos lanzaban llamas.

—iHáblame de usted, hijo de puta!

—No puede pegarme, no puede ni tocarme.

Me abalancé sobre él y seguí pegándole en la cara, en la boca, en las orejas. No era una reacción histérica; los golpes eran certeros, concienzudos, secos. La mano se me había dormido, pero continué, el ruido de los golpes sonaba en todo el recinto. Se escondió tras los brazos.

— ¡Déjeme, yo no he hecho nada!

Retrocedí un paso con esfuerzo de voluntad. Me apetecía seguir atizándole, pero procuré retenerme (Giménez Bartlett, 1996 [2013]: 1141).

Clara Deza se humaniza, es una mujer con «problemas de mujeres», a lo que hay que añadir una vida profesional. Ramón pregunta a Clara sobre una conversación que había tenido con la madre de éste, Esmeralda.

La media hora tarde de siempre, esa media hora de más discutiendo porque él no lo puede evitar.

-Al final no me has dicho qué quería mi madre. 
-Nada, hablar de cosas de mujeres. Lo que yo te decía, el climaterio.

- ¿Y para eso tanta movida?, ¿y por qué no llamó a mi hermano?

-Pero bueno -responde con cansancio, tirándose en el sofá y quitándose los

zapatos uno contra otro-, ¿no eras tú el que decía que igual necesitaba comprensión femenina, hablar de mujer a mujer? Pues eso» (Castro, 2008 [2010]: 213).

Estamos hablando de mujeres cuyas reivindicaciones van más allá de un deseo de igualdad legal, reivindican su diferencia, «ser mujer» como valor. Teresa Sinde, por otra parte, es un personaje de los márgenes cuya personalidad y conducta está sometida a las presiones que su madre (madre-monstruo) ha ejercido desde su niñez sobre ella, aunque «funciona» gracias a su trabajo y un entorno de amistades y familiar sólido.

Las protagonistas femeninas de otras sagas escritas por autores y con protagonista femenina cuentan con la misma particularidad. José María Guelbenzu (1944- ) escoge a una jueza como personaje central de su serie sobre Mariana de Marco $^{120}$, concienzuda, seria y profesional, pero con una sensibilidad especial, ¿por ser mujer? Tal vez sea porque el personaje, para el escritor, es una excusa en un ejercicio literario. Guelbenzu confiesa:

Me lo sugirió una joven con la que me crucé y que me llamó la atención, pero a partir de ahí todo es inventado [...] Me atrajo lo que daba a entender desde fuera, su carácter, su exterioridad, cierto aire de independencia. Pero, como le digo, aquello fue una impresión a partir de la cual yo cree al personaje que he

\footnotetext{
${ }^{120}$ Debemos tener en cuenta dos cuestiones a la hora de analizar la obra de Guelbenzu: la primera que propio autor reconoce su interés por la novela negra está mediado por su interés por adquirir fluidez a la hora de escribir, pero no siente un inclinación especial por este género. En una de sus entrevistas el escritor reconoce: «Yo escribí mi primera novela policíaca por hacer pluma. Era una época de sequía literaria en que no sabía muy bien qué hacer. Me metí en esa novela sin más, y ahí Mariana de Marco era uno de los muchos personajes que había. Lo que pasa es que una vez cerrada la novela, y después de haber hecho otras muchas cosas, me di cuenta de que ese personaje a mí me fascinaba, y entonces seguí con ella. Para eso, lo único que yo podía hacer era seguir haciendo novela policíaca» (Guelbenzu, en Gordo, 22 de septiembre de 2014: en línea).
} 
venido desarrollando (Guelbenzu en Gordo, 22 de septiembre de 2014: en línea).

José María Guelbenzu es un sólido escritor y crítico literario con una larga carrera en ambos campos. La crítica suele nombrarlo junto a otros autores de su generación como Joaquín Leguina (1941- ), Juan Carlos Somoza (1959- ) o Juan Madrid (1947- ), como autores que desarrollan la novela negra en España después de la Transición. Antes de crear a la jueza de Marco ya había escrito un número importante de novelas y relatos ${ }^{121}$, incluso algún poemario. La saga de Mariana de Marco consta de ocho volúmenes ${ }^{122}$ : No acosen al asesino (2001), La muerte viene de lejos (2004), El cadáver arrepentido (2007), Un asesinato piadoso (2008), El hermano pequeño (2011), Muerte en primera clase (2011), Nunca ayudes a una extraña (2014), El asesino desconsolado (2017). Para Concepción Bados Ciria (2010: 36) Guelbenzu con Mariana de Marco sigue la fórmula de la novela negra de los orígenes, personajes como Sherlock Holmes o George Simenon. La historia se presenta como un juego con la lectora (o lector) que consiste en que ésta siga las vistas para descubrir al asesino. En No acosen al asesino (2001), parece que esta estructura se rompe, ya que el público conoce al asesino en las primeras líneas, siendo la duda si se podrá escapar y cuáles pueden haber sido los motivos. El enigma se le presenta a la lectora y el lector al intentar descubrir quién es el asesino en realidad (en cuanto a personalidad).

Mariana de Marco era «la juez titular del juzgado de Primera Instancia e Instrucción de San Pedro del Mar». De unos cuarenta años, de Marco era una mujer muy atractiva:

Alta, de figura atlética y voz profunda, no sólo llamaba la atención por su tipo de mujer grande sino también por la expresión decidida que acompañaba todos sus ademanes. Lucía una especie de melena muy corta que dejaba las

\footnotetext{
${ }^{121}$ Hogar eventual (1967), Espectros, la casa antigua (1967), La donna de otoño (1967), El mercurio (1968), Antifaz (1970), El pasajero de ultramar (1976), La noche en casa (1977), El río de la luna (1981), El esperado (1984), La mirada (1987), La tierra prometida (1991), La mosca de Funchal (1992), El sentimiento (1995), Recuerdo una vez en Argüelles (1997), Un peso en el mundo (1999). Después de comenzar la saga de Mariana de Marco ha publicado: La cabeza del durmiente (2003), Esta pared de hielo (2005), El amor verdadero (2010), Mentiras aceptadas (2013), Los poderosos lo quieren todo (2016).

122 El autor ha reconocido que desde el comienzo de la saga tiene previsto que finalizará con la décima entrega (Gordo, 22 de septiembre de 2014)..
} 
orejas medio al descubierto, unas orejas pequeñas, ligeramente abiertas y rematadas por dos diminutos brillantes; pero lo más interesante de su rostro - de rasgos no tanto finos como contundentes- eran los ojos grandes, castaño oscuro, que casaban a la perfección con el cabello del mismo color (Guelbenzu, 2001: 12).

El personaje de Guelbenzu se asemeja en muchos aspectos a Petra Delicado. Sin embargo, Giménez Bartlett no nos describe a la inspectora físicamente, en alguna ocasión nos puede decir cómo va vestida o qué se va a poner, cómo se siente. Ambas habían ejercido como abogadas. De Marzo es independiente, inteligente y divorciada, sin hijos. En diferentes entregas tiene distintos amantes, como Petra casi a lo largo de toda la serie, pero Mariana no se compromete con ninguno de ellos, se siente feliz con su soltería.

[Andy era raro], pero a ella le venía tan bien en ese momento el modo de relación que habían establecido, [...] Con ella, él era tan apasionado como distante, una ecuación difícil de resolver, pero que se formulaba muy gratamente a lo largo del año en sus varios encuentros esporádicos y, de otro modo, en encantadoras conversaciones al calor del teléfono o en juegos de ingenio, medio eróticos, medio intelectuales, por el correo electrónico (Guelbenzu, 2001: 70).

Otra diferencia entre Mariana de Marco y Petra Delicado es el círculo de amistades femeninas de las que presume la jueza. Petra hemos visto que tiene pocas relaciones femeninas y poco fluidas. «Sonsoles Abós era, por así decirlo, la amiga de verano de la juez de Marco» (Guelbenzu, 2001: 33). Cada nueva novela nos desvela aspectos sobre la jueza de Marco, por ejemplo, descubrimos que su amiga íntima es Julia Cruz, una arquitecta que tiene estudio en $\mathrm{G}^{123}$. El escritor también nos describe cómo es físicamente: «Es una mujer grácil, de cuerpo fino, con aspecto de muchacho, pelo castaño cortado a lo garçon, el cutis lleno de pecas y tan alta como Mariana» (Guelbenzu, s.f.). Se trata de una mujer emotiva, leal y directa, comparte muchas de las cualidades de la jueza.

123 Mariana de Marco, en las primeras entregas de la serie, era la jueza de Primera Instancia e Instrucción de San Pedro del Mar. A partir de la cuarta novela de la saga, Un asesino piadoso (2008), de Marco se traslada a la ciudad Cántabra de G. (todo indica que es Gijón, aunque no se menciona) para cubrir una vacante en el juzgado de Primera Instancia e Instrucción. 
Guelbenzu no es el único escritor que sitúa a personajes femeninos en sus novelas negras, hemos mencionado antes que Lorenzo Silva crea a Chamorro ${ }^{124}$ como una de las protagonistas de la serie de Bevilacqua, que hemos introducido en el tercer capítulo. El autor confiesa que no tenía la intención de que ni Rubén Bevilacqua ni Virginia Chamorro «fueran representativos de nadie más que de sí mismos, no constituyen el promedio ni una manifestación típica de lo que hoy pueda ser un guardia o una guardia civil» (Silva, 2008: en línea). Para Silva, la joven guardia civil sentía una «vocación militar frustrada (y con un carácter inquieto y despierto), porque era una posibilidad que me proporcionaba la entonces aún reciente incorporación femenina al Cuerpo, donde habían recalado no pocas jóvenes para las que el ingreso en las Fuerzas Armadas» (Silva, 2008: en línea). El escritor señala que era consciente de que aquellas personas que todavía pensaban en el estereotipo le criticarían pero que para él era importante que estas particularidades fueran «el cimiento ideal para crear unos personajes de ficción que resultaran originales, atractivos y en suma, memorables» (Silva, 2008: en línea). Personajes alternativos que plantean nuevas representaciones (positivas) de los roles de género.

Así pues, podemos afirmar que hay una nueva generación de escritoras con sensibilidad hacia los temas de género que, de manera intencional o no, crean nuevos referentes para las lectoras y abren el género negro a un público al que tradicionalmente se le había dado la espalda, como hacen sus compañeras de profesión, que están acompañadas por escritores varones de su generación..

Las sociedades occidentales, a las que circunscribimos nuestra investigación, han dividido tradicionalmente los espacios sociales en público y privado, y a pesar de todos estos ejemplos de mujeres destacadas en el ámbito público, los estereotipos de género circunscriben a las mujeres al hogar y le dan la prioridad del espacio público a los hombres. Toda esta situación se quiebra cuando las mujeres comienzan a exigir derechos. Poco a poco, las reivindicaciones dan sus frutos y las mujeres ocupan espacios públicos, también espacios profesionales. Los

\footnotetext{
${ }^{124}$ Silva inicia la serie con una Virginia Chamorro número de la Guardia Civil sin demasiada experiencia y la finaliza, hasta el momento, como cabo.
} 
espacios profesionales clásicos para las mujeres son una extensión de las tareas que desarrollan en el espacio privado, como son los cuidados (enfermeras, maestras...). Sin embargo, hay mujeres que, durante el XIX y principios del XX, optan por profesiones menos «femeninas», como ser periodistas, fotógrafas de guerra, aviadoras... y, cómo no, milicianas que en épocas más recientes se convierten en militares y policías. Inspectoras como Petra Delicado y Clara Deza.

Otro espacio bastante masculinizado es la cocina de los grandes restaurantes. Es fácil comprobar esta afirmación, incluso hoy día, con un sencillo ejercicio. Si pensamos en profesionales de todo el mundo que trabajen en la cocina, la mayoría conocemos a aquellos que aparecen en los medios de comunicación porque tienen un programa de cocina, presentan algún tipo de reality show, han ganado una o varias estrellas Michelín, etc. La respuesta resulta abrumadora y nos demuestra cómo en el momento en que se profesionaliza y prestigia una tarea, los hombres ocupan esos espacios más visibles del espacio público. Teresa Sinde es un ejemplo de ruptura en este sentido. Y no olvidemos que Sinde también trabaja en el mundo de la producción audiovisual, otro ámbito fuertemente masculinizado cuando hablamos de puestos directivos de toma de decisiones, no tanto en los escalones de base que suponen estar de cara al público, y en los que la feminización supone una prolongación de los estereotipos menos positivos sobre la apariencia física y la objetualización de las mujeres.

Así pues, las tres protagonistas tienen algo en común, además de trabajar en oficios tradicionalmente masculinos, realizan su trabajo con profesionalidad.

\section{Myung N. Choi apunta sobre Petra Delicado que}

[...] su personalidad y carácter contradice el estereotipo de mujer sumisa que desea proteger su honor y cuidarse del qué dirán. A medida que la serie de Petra Delicado avanza, Alicia Giménez Bartlett presenta paulatinamente una evolución de su personaje, puesto que la inspectora cambia de mujer solitaria a una profesional que sabe balancear su trabajo y su vida personal de manera inteligente. Petra también logra ser reconocida por la fuerza policial por su 
desempeño en el lugar de trabajo donde predominan los hombres (Choi, 2012: 20).

Estamos de acuerdo con esta autora, pues un personaje que se narra y se construye a lo largo de una saga evoluciona, $y$, por tanto, hay que considerarla en su conjunto.

Ya hemos señalado que en España el acceso de las mujeres a los cuerpos y fuerzas de seguridad del Estado es relativamente tardío respecto a los países del entorno y, en cierto modo, permite trabajar mejor las reivindicaciones y la ruptura con un sistema patriarcal heteronormativo. Vijaya Venkataraman (2010: 231) afirma:

[...] mientras que la novela policíaca puede interpretarse como una crítica dura de la sociedad y las leyes que las gobiernan, el hecho de seguir la fórmula hace que se convierta en una apología del orden social y el statu quo. Esta tensión aumenta aún más cuando se trata de la novela policiaca escrita por mujeres, con protagonismo de la mujer investigadora. La gran pregunta entonces que nos enfrenta es si es posible escribir una novela policíaca que sea reconciliable con la consciencia femenina.

Por nuestra parte consideramos que sí, que a pesar de la tensión que se genera subyace una corriente de conciencia sobre la situación de las mujeres al describir las relaciones de las protagonistas con el resto de personajes, su trabajo, su familia, etc. Sabemos que no hay un único punto de vista sobre el hecho de que la novela negra sea empoderadora y rompa con los estereotipos patriarcales o, por el contrario, refuerce los modelos mainstream de mujeres y hombres, pero consideramos que, en cualquier caso, es empoderadora porque se produce un cambio respecto a lo que se consideraba la normalidad. La popularidad de la novela negra puede ser empleada para visibilizar las cuestiones de género y hacer una crítica de la situación de desigualdad. Venkataraman (2010: 231) decide abordar la novela negra escrita por mujeres. En la misma línea de argumentación, Kathleen Klein:

[...] acepta que el uso de protagonistas femeninas en un espacio masculino parece favorecer metas feministas porque ayudan a modificar las actitudes de los lectores que se acercan a estas novelas desde perspectivas conservadoras. 
La mujer detective está dotada de una complejidad psicológica por lo que rechaza los estereotipos de género (Klein en Venkataraman, 2010: 231).

Ante esta afirmación concluimos que las mujeres pueden y deben crear una ficción que tenga consciencia de género, utilizando al mismo tiempo la fórmula de la literatura popular en beneficio de la un cambio hacia una sociedad más igualitaria.

Antes de continuar con el desarrollo de los aspectos positivos de la representación de personajes femeninos en la novela negra realizaremos un pequeño inciso sobre lo que sucede con los modelos de representación de la masculinidad en el género negro. La novela negra tradicionalmente se ha inclinado por representar a personajes masculinos que se ajustaban a la representación del hombre dominante: blanco, heterosexual, duro (parco en sentimiento), etc. Àngels Carabí (2000) argumenta que la masculinidad hegemónica gravita y se reafirma con actitudes sexistas, racistas y homófonas. En el mundo anglosajón encontramos ejemplos como Chester Himes (1909-1984) que creó a Ataúd Ed Johnson y Sepulturero Jones, dos detectives negros de la policía de Nueva York que están destinados en Harlem ${ }^{125}$. La obra de Himes emana ira, debemos tener en cuenta que todas las novelas de la serie se escribieron entre 1957 y $1968^{126}$, como

125 La serie de Ataúd Ed Johnson y Sepulturero Jones está compuesta por los siguientes títulos: Por amor a Imabelle (For Love of Imabelle or A Rage in Harlem, 1957), La banda de los musulmanes o El jeque de Harlem (The Real Cool Killers, 1959), Un loco asesinato o El extraño asesinato (The Crazy Kill, 1959), El gran sueño de oro (The Big Gold Dream, 1960), Todos muertos (All Shot Up, 1960), Algodón en Harlem (Cotton Comes to Harlem, 1965), Empieza el calor o Cuando el calor aprieta (The Heat's On or Come Back, Charleston Blue, 1966), Un ciego con una pistola (Blind Man with a Pistol or Hot Day Hot Night, 1969), Plan $B$ (Plan B, 1993).

${ }^{126}$ El inicio de la lucha por los derechos civiles de la población negra en Estados Unidos se sitúa en 1955 con el asesinato de Emmett Till, un joven de Chicago asesinado en Mississippi cuando visitaba a su familia. Posteriormente otros hitos fueron: el boicot a los autobuses de Montgomery iniciado por Rosa Parks, también en 1955; el fin de la segregación escolar tras el fallo del Tribunal Supremo sobre el caso de Brown (Little Rock, Arkansas, 1957); las movilizaciones en Mississippi (1962), Albany (1691-1967), Birmingham (1963-1964), que culminaron con la gran Marcha sobre Washington (28 de agosto de 1963) donde Martin Luther King, uno de los líderes del movimiento, pronunció la famosa frase: «Yo tengo un sueño»; el asesinato de Michael Schwerner, Andrew Goodman y James Chaney, un grupo de voluntarios del «Verano de la Libertad» en Mississippi en 1964 supuso el espaldarazo definitivo a las reivindicaciones del movimiento, ya que provocó la quiebra de la fe de gran parte de la población en los 
personajes de novela negra se ajustan a los cánones clásicos de la hard-boiled, dos tipos duros cuya honradez está fuera de duda. No se dejan sobornar y persiguen, únicamente a los criminales violentos, dejando que el resto de personajes del lumpen (prostitutas, homosexuales, drogadictos...) sobrevivan con sus actividades. Resulta curioso, recordemos el momento histórico en el que se desarrolla la acción, que estos detectives a pesar de todo cuentan con el beneplácito de sus jefes (el capitán Brice y el teniente Anderson), ambos blancos.

Walter Mosley (1952- ) también se decanta por un detective afroamericano en su serie Easy Rawlins ${ }^{127}$. Ezquiel «Easy» Rawlins es un veterano de Vietnam que nació en 1920 en Houston (Texas) y que ha tenido una vida muy agitada hasta acabar trabajando en el mantenimiento de un instituto. Sus novelas cubren el espacio de tiempo que va desde 1948 hasta 1967 y el racismo es un tema recurrente. Easy mantiene una relación complicada con la policía, pero la relación es beneficiosa para ambas partes en cuanto a resolver crímenes se refiere. Las historias nos llevan a visitar diferentes ambientes de Los Ángeles, desde mansiones hasta barrios marginales.

Los personajes de Himes y de Mosley pertenecen a la tradición hard-boiled y son representados como duros, mujeriegos y con principios morales firmes. Están muy lejos de la representación de masculinidades alternativas, por lo tanto, aunque son afroamericanos, siguen representando modelos heteronormativos.

Hemos mencionado anteriormente que hay algunos ejemplos de detectives homosexuales, ¿son positivos los modelos que representan? Este aspecto lo desarrollaremos más adelante en el apartado sobre la sexualización de las protagonistas de la novela negra, a pesar de ello, sí podemos señalar que, dentro de

denominados «valores del sur», que se sustentaban en la segregación y discriminación racial. Será en 1965 cuando se promulgue la Ley de derecho a voto en la que se prohibirá la discriminación racial en cuando al derecho al voto.

${ }^{127}$ El demonio vestido de azul (Devil in a Blue Dress, 1990), Una muerte roja, (A Red Death, 1991), Mariposa blanca (White Butterfly, 1992), Betty la negra (Black Betty, 1994), Un perro Amarillo (A Little Yellow Dog, 1996), De pesca (Gone Fishin, 1997), El caso Brown, (Bad Boy Brawly Brown, 2002), Six Easy Pieces: Stories (2003), Muerte escarlata (Little Scarlet, 2004), Beso Canela (Cinnamon Kiss, 2005) y Rubia peligrosa (Blonde Faith, 2007). 
un género fórmula, las representaciones suelen caer en muchas ocasiones en los estereotipos menos positivos.

Parece que pocos autores representan nuevas masculinidades más positivas que las tradicionalmente establecidas por el patriarcado. Sin embargo, existen jóvenes escritores que buscan identificarse con los personajes que crean, como en el caso de Eloy Moreno en El bolígrafo de gel verde (2009), donde el protagonista entabla relaciones en el marco de la heterosexualidad lejos de la dominación que ejercen los investigadores en la novela negra.

Antes de estos nuevos escritores nos encontramos el experimento de «novela negra humorística» (Vallés Calatrava, 1991) de PGarcía y el detective Gay Rose Flower. El primer guiño de humor es el propio nombre del protagonista que hasta en tres ocasiones reafirma su orientación sexual: Gay, como diminutivo de Gaylor, su nombre; Rose, ahondando en la idea de la ambigüedad sexual, sobre todo cuando el protagonista reconoce el origen de este nombre, «mamá siempre deseó una niña y cuando papá la dejó en estado de buena esperanza, pensó que nacería una niña» (PGarcía, 1982: 53). Así que como ya tenía la ropa bordada con una R. decidió que le pondría una G. delante y mantendría el nombre de Rose; finalmente, el último guiño del autor es el apellido, Flower. Debemos recordar que en inglés a los homosexuales se les llama despectivamente así.

Flower se representa como un individuo preocupado por su aspecto, elegante, se dirige a todos los hombres con muletillas como cariño, querido, etc. Además exhibe cualidades que se asignan a las mujeres tradicionalmente, como la cocina o la limpieza de la casa. Así pues, vemos que PGarcía128 representa una

\footnotetext{
${ }^{128}$ Nos numerosos los relatos y novelas en los que PGarcía sitúa a Gay Flower como protagonista. Por ejemplo: «Orgía sexual en el invernadero de orquídeas y perejil» (1976), «Manchas de sangre y moco en un cortaúñas chino» (1976), «Mafia y travestismo con secuestro de testículo de cargo» (1977), Gay Flower, detective muy privado (1978), «El ladrón de orgasmos» (1979), «La leyenda de Fulwider y Trevillyan» (1981), El nombre es Flower (1982), Flower, al aparato (1982), Demasiados muertos para Flower (1983), Flower en El calzoncillo eterno (1983), ¿Pero hubo alguna vez 800.000 puestos de trabajo? (1984), Flower en El Tataranieto del Coyote (1985), El Método Flower (incluye el remake de dos relatos: «Encontrar un culpable» y «Adiós, muñeco» publicados en 1975, 1991), Flower siempre llama dos veces (1995), Flower, blanco y negro (1996), La leyenda de Fulwider y Trevillyan (1996), Mi nombre es Flower (1997), La venganza de Flower (1997), Flower, te necesito (1998), La clienta de Flower (1999), Fulwider, Trevillyan \& Moriarty, Ltd. (1999),
} 
masculinidad diferente a la dominante en el género negro, usando para ello el humor ${ }^{129}$.

En cuanto a mujeres que representan la homosexualidad en sus relatos lo analizaremos más adelante con diferentes ejemplos.

Nuestro análisis parte de la posición, ya mencionada, de Venkataraman (2010), por ello observamos en las personas de Petra, Clara y Teresa unos modelos positivos, al visibilizar situaciones cotidianas en las que las mujeres se pueden ver reflejadas y reflexionar sobre su situación. Asimismo, describen las diferentes estrategias que adoptan las protagonistas ante las situaciones que se les presentan «a diario», al contrario de lo que opinan autoras citadas por Shelley Godsland (2011), que afirman que en la contemporaneidad ha desaparecido el discurso teórico feminista con la apariencia de que no hace falta porque ya se ha conseguido la igualdad.

It is perhaps in this realm, then, that what commentators such as Milagros Rivera or Carmen Alborch see as the dangerous 'masculinization' of the working female comes to the most clearly within the series. An once again, as in the case of the detective's use of expletives, we must read GiménezBartlett's expensive exposition and analysis of this particular theme as a device constructed to lay bare the considerable anomalies of the professional woman's situation in contemporary Spain (Godsland, 2011: 54).

Por nuestra parte consideramos que la visibilización de las dificultades de las mujeres en ámbitos laborales masculinizados es positiva, provocando una conciencia de feminismo, aunque no se verbalice como tal. Y esto sucede en ocasiones en las novelas que analizamos en esta tesis.

Flower, punto final (2002), Flower total (incluye tres relatos inéditos: «Flower cambia el paso», «La secretaria de Flower» y «Los archivos de Flower», 2010).

${ }^{129}$ Aquí cabe puntualizar que PGarcía crea a Gay Flower en plena Transición, un momento de apertura sociocultural y política, en Madrid se desarrolla la denominada Movida. Rafael Cervera Torres (2012) la define en los siguientes términos: «La nueva ola madrileña había mutado en una definición mucho más abstracta: la movida. Si la nueva ola era asunto casi exclusivo de músicos, la movida incluía también artistas plásticos, diseñadores, directores de cine, actores y actrices, caraduras, periodistas y, en definitiva, a todo bicho viviente que tuviese ganas de aparcar el aburrimiento y hacer algo». 
Críticas como Maureen Reddy y Shelley Godsland afirman que la presencia de la mujer en la novela policíaca rompe con las convenciones genéricas y estereotipos ya que presentan la trama desde perspectivas femeninas. La sustitución de un hombre solitario, cínico y marginal por una mujer independiente, liberada y auto-consciente parece funcionar para subvertir y cuestionar el orden patriarcal (Venkataraman, 2010: 231).

En su primera etapa profesional Petra Delicado compartía bufete con Hugo $^{130}$, su primer marido. La inspectora reflexiona sobre ello en una conversación con Garzón, el compañero de Petra:

[...] ambos éramos jóvenes, brillantes en los estudios, no mal parecidos... Nos conocimos en la facultad y acabamos la carrera al mismo tiempo. Decidimos montar un bufete de abogados con dos socios más que, contra todo pronóstico, funcionó muy bien. Luego, poco a poco, Hugo fue tomando el papel principal y yo me quedé como una mera pasante. Trabajo seguro pero sin protagonismo y con el marido de jefe. Ya ve, las cosas estaban cantadas, ¿o no? (Giménez Bartlett, 1996 [2013]: 102).

Esta posición secundaria en el ámbito laboral se justifica por el tipo de relación patriarcal-tradicional que mantenía el matrimonio. De hecho, como anécdota, Petra cuenta:

Era la primera vez que citaba su nombre, sonaba bien. Cuando estuve casada con él [Hugo] intentó convencerme varias veces de que cambiara mi nombre de forma legal. Petra le parecía poco distinguido; que mi abuela se llamara así era un accidente que no debía ser determinante de por vida. Le gustaba más Celia. Estuve a punto de hacerle caso, pero felizmente me negué. Sin embargo, desde entonces no era capaz de decirle a alguien mi nombre por primera vez sin sentir un ramalazo de culpabilidad. Petra era en verdad horrible, quizá no hubiera sido mala idea sustituirlo (Giménez Bartlett, 1996 [2013]: 40).

Petra Delicado decide cambiar el rumbo de su vida profesional y se hace policía. Petra reconoce que pese a su «brillante formación» como abogada en la

130 «Hugo tenía un aspecto distinguido y cansado, como si acabara de salir de una enfermedad tomando las aguas en un balneario. El paso del tiempo le favorecía, las sienes grises, su cuidado en el vestir. Caducados los plazos florecientes de la Naturaleza, la experiencia y el dinero hacían lo suyo» (Giménez Bartlett, 1996 [2013]: 20). 
Academia de Policía no le daban casos de «relumbrón». Presentaba dos hándicaps: ser una intelectual y ser mujer. Así que acabó destinada en el Departamento de Documentación, «donde me ocupé de temas generales; archivos, publicaciones y biblioteca, lo cual acabó por fijarme un estatus meramente teórico en la consideración de los compañeros» (Giménez Bartlett, 1996 [2013]: 9). Petra se esfuerza por mantener una actitud profesional en todo momento para mantener el respeto de sus compañeros:

Nadie en mi trabajo sabía nada de mi vida privada. Me parecía una condición indispensable para no perder el respeto general. Había visto a algunas compañeras dar consejos a sus niñeras por teléfono en presencia de todos. «Échale en la papilla un puñadito de arroz, tiene el vientre algo flojo». Pensaba que no podía ser de esa manera, por mucho que después fueran capaces de resolver el enigma de los diez negritos; aquellas mujeres olvidaban que existía aún un largo camino de formas por recorrer. Nunca había descubierto a ningún inspector macho llamando a su casa preocupado por la gastronomía infantil. Y las cosas no habían llegado al punto neutro en el que se puede mostrar sin consecuencias cierta debilidad (Giménez Bartlett, 1996 [2013]: $10)$.

Petra reclamó servicios activos, pero no la invitaron nada más que a participar en casos de pequeños robos. Mujer práctica, no se había hecho policía inspirada en las películas de acción o las novelas negras. Sin embargo, su trabajo en los archivos la frustraba aunque no perdía la esperanza de que algún día llegara su oportunidad en el servicio activo. Petra soporta esta situación porque:

[...] creía que una mujer no puede dedicarse a lloriquear en su puesto de trabajo sin provocar una reacción fatal. Esperaba en silencio mi ocasión, y cuando otro inspector se cruzaba conmigo en el pasillo y preguntaba: «¿Cómo está nuestra intelectual?», yo por dentro siempre pensaba: «Algún día se verá quién soy», y por fuera le daba un par de masticaciones irónicas al chicle en señal de saludo y me limitaba a sonreír (Giménez Bartlett, 1996 [2013]: 9).

Y ese día llega, aunque se deba a que los demás están demasiado ocupados:

Pues ya que no lo sabe se lo diré: nos lo han encargado porque no tenían a nadie más, así de sencillo. Me he enterado esta mañana. El resto de 
compañeros está realizando una operación muy complicada, algo de drogas. Una de esas historias con fotos finales en el periódico y mucho material incautado. -Parecía haber recibido el proyectil pero remoloneó. Como de costumbre no quieren gente de otra comisaría, y de no haber sido por la falta de personal, nos hubieran dejado donde estábamos a fulltime, yo en mi archivo y usted con su alijo. No creo que tuvieran confianza en nosotros para un trabajo de tanta responsabilidad. Al fin y al cabo usted es casi un jubilado y yo sólo soy una mujer (Giménez Bartlett, 1996 [2013]: 23).

La situación de Clara Deza no es mejor que la descrita por Petra:

Como si ya no hubiera suficiente con una mujer entre los muchachotes, entre los sabuesos, entre los polis guays que deducen y resuelven igual que en las novelas, como si no fuera suficiente con el inspector jefe apretando cada vez más, que no me traéis detenidos, que tenemos muy mal porcentaje este trimestre, que al ritmo que vamos nos quedamos atrás y eso no puede ser, en las otras comisarías treinta detenciones cada día y antes prefiero mil veces pillar a media docena de chorizos que a un pez gordo, que a fin de cuentas son más palotes y si eso es lo único que les importa a los políticos para qué nos vamos a comer la moral. Pues eso (Castro, 2008 [2010]: 12-13).

Petra en la misma línea, se da cuenta de que: «No estaba preparada para aquella reacción intempestiva. Definitivamente aquello no era el servicio de documentación. Habría que lucir coraza y armas ofensivas si no quería perder el respeto de mi subordinado» (Giménez Bartlett, 1996 [2013]: 24).

Esta coraza no sólo la exhibe con los delincuentes y testigos sino que también la tiene presente cuando defiende sus «intereses» frente a su jefe o su compañero. Para ello, usa la coartada que antes decía no querer utilizar, la de ser mujer. «El comisario me trataba con mayor respeto que en la primera parte de la investigación. Lo atribuí a mi andanada feminista, en ningún caso a los progresos que hubiéramos podido hacer. Resultaba evidente que, para dar cualquier paso, hay que tener una boca bien entrenada para el mordisco» (Giménez Bartlett, 1996 [2013]: 112). Esta coraza, Petra la debe mantener a lo largo de la serie al enfrentarse a otros profesionales que la tratan de manera paternalista $y$ 
condescendiente: «El sargento Pinilla quiso hablar conmigo personalmente tras recibir el encargo de Garzón. Me miraba con cara de reproche, leyéndome la cartilla profesional. -Pero inspectora, usted tendría que saberlo, en la Guardia Urbana no admitimos denuncias de perros desaparecidos o robados» (Giménez Bartlett, 1997 [2013]: 315).

Clara, por el contrario, se muestra más sentimental, ya que, mientras Petra se revela igual de «dura» en el trabajo y fuera de él, Clara reconoce la contradicción en que se convierte su vida profesional y personal: «Que soy una contradicción andante lo sabe todo el mundo, pero Ramón aún se asombra de mis opuestos. Yo creo que se puede ser animal e intelectual a la vez, surreal y verosímil, infernal y angelical, real y provisional, sensual, policial, habitual en su cama y retráctil a un tiempo, cerebral, espectral, azul, natural» (Castro, 2008: 23).

En un incidente con Carlos París, su compañero y un antiguo ex, éste le pide a Clara que sean profesionales.

[...] yo no te estoy diciendo que nos vayamos a tomar una caña juntos ni que haya olvidado de un plumazo todo lo que me hiciste al final, pero deberíamos intentar ser profesionales, recordar que servimos al Estado por encima de nuestras rencillas personales $\mathrm{y}$, al menos y en nombre de la Patria, intentar soportarnos.

-Hombre, si me lo pides en nombre de la Patria y por el bien del caso... -y rebosando ironía por la comisura de una sonrisa que no acaba de parir, se desliza por el hueco que resta entre los asientos y se deja caer delante.

-Es del caso de lo que quería hablarte.

-Estupendo, porque lo cierto es que he estado mirando este aparatejo mientras la del juzgado tonteaba contigo y tú te dejabas y me apuesto lo que sea a que en la agenda hay números interesantes que seguro que nos pueden ayudar (Castro, 2008: 91).

La protagonista, molesta, responde como siempre con ironía y Carlos le dice que el hecho de que no considere que haya caso no es algo personal. Clara sí se lo toma como personal, ya que cuestionarla profesionalmente es cuestionarla personalmente. 
-Clara, no te embales: para mí no hay caso.

Ella se queda en blanco, paralizada y con expresión de sorpresa ante el fotomatón, como si hubiera sido inmovilizada por el cruel dedo que en el mando del vídeo pulsara el botón de pause. Pero poco a poco, a pesar de la lentitud que imprime al cerebro la noticia, a pesar del chaparrón de hielo y de la lasitud de los miembros, los cabos se van atando y las furias encuentran su lugar.

-¿Para eso querías que pasara aquí delante?

-No empieces, no es nada personal.

-No, por supuesto que no es personal, es justo lo contrario. Yo te doy exactamente igual, eso lo tengo asumido desde hace tiempo y no me importa, pero lo mismo te pasa con el Culebra, que te da igual, que no consideras su muerte ni una desgracia ni un crimen ni una pérdida. No es personal, qué va a ser personal si ni siquiera lo calificas de persona.

-Volvemos a lo de siempre, te obcecas en la única realidad que ves, la tuya, y no te paras a pensar con objetividad. No hay caso. Asúmelo, es un yonqui cualquiera muerto por una sobredosis cualquiera. Pura rutina.

-Aquí el único rutinario eres tú, que no ves más allá, porque resulta que no, que no era un yonqui cualquiera sino un confidente de la Policía que días antes nos había dado un soplo muy importante. (Castro, 2008 [2010]: 91).

Clara tiene un fuerte sentido de la justicia, en parte porque todo le importa, porque deja que sus sentimientos, sobre todo la empatía, en ocasiones le guíen en su profesión. En cierto modo es lo que la convierte en una buena profesional capaz de resolver los casos.

Por su parte, Petra, una vez se ha incorporado al servicio activo ya no quiere abandonarlo, se frustra y no quiere volver al archivo.

Durante la semana siguiente me reintegré a mi trabajo habitual en el departamento de documentación. Había sido como comer un poco de maná, ahora todo me parecía insípido si me ponía a hacer comparaciones. Había un componente enormemente excitante en el trabajo de investigar, hubiera sido tonto haberlo negado. Era como viajar sentado en un tren, aunque tu cuerpo 
permaneciera tranquilo, las cosas avanzaban a tu alrededor, todos los implicados seguían actuando. Tú te quedabas allí, pensando, ordenando los hechos, con los ojos bien abiertos para no pasarte de estación. También era emocionante aquel contacto a tumba abierta con la realidad, ser testigo de la miseria moral, la podredumbre, el horror (Giménez Bartlett, 1996 [2013]: 8990).

Con el tiempo Petra consigue prestigio y es asignada al servicio activo en el Departamento de Homicidios, donde hace una labor reconocida, con casos importantes, como en Mensajeros de la oscuridad (1999) o Muertos de papel (2000), si bien es cierto que en algunas ocasiones todavía le asignan trabajos que nadie quiere, como en Nadie quiere saber (2013).

Un aspecto interesante que ahonda en los prejuicios de los estereotipos profesionales asignados a mujeres y hombres, y de los que son conscientes las protagonistas, se ilustra con diferentes episodios. Por ejemplo, en Días de Perros (1997), Petra lleva al veterinario al perro-testigo Espanto y comenta: «Tuve que rellenar una ficha de cliente. Como no tenía deseos de ser objeto de miradas curiosas ni de dar explicaciones, en la casilla destinada a profesión escribí "Bibliotecaria"» (Giménez Bartlett, 1997 [2013]: 258). En Nido vacío (2007), Petra se acerca a hacer una entrevista a un centro de acogida y ve en un parque a una anciana que había estado en el centro de acogida durante la Guerra Civil. La mujer le pregunta por su profesión y responde: «-¡Eh, oiga! ¿Puede decirme a qué se dedica usted? -Soy profesora -mentí. Tenía la impresión de que, si le decía la verdad, aquel hermoso cuadro bucólico de tulipanes y tranquilas charlas se estropearía. ¡Es terrible tener una profesión que siempre empaña el gesto de los demás!» (Giménez Bartlett, 2007 [2013]: 1519).

Las protagonistas de Mercedes Castro no se enfrentan a esta disyuntiva de tener que mentir, ya que la autora las sitúa en su ámbito laboral o en un ámbito personal en el que todas las personas conocen su profesión (amistades, familia, etc.). Se muestran más abiertas con su trabajo. 
En los ámbitos laborales masculinizados puede haber problemas de machismo. Clara Deza se ve obligada a enfrentar este machismo de manera habitual, lo que nos permite afirmar que existe una conciencia de la situación de desigualdad de las mujeres que la autora, Mercedes Castro, quiere poner de manifiesto. «Tenía que haberse levantado a las 7:00, pero eran las 7:33. Y sabía que llegaría tarde, claro, como siempre, las mujeres con el secador y pintándose la pestaña ya se sabe, je, je, diría el estúpido de la puerta al verla llegar» (Castro, 2008 [2010]: 6). Pero no solamente en esta situación. Su jefe la trata con condescendencia y su compañero, un antiguo novio, Carlos París, con paternalismo que detesta: «ya se sabe que a las mujeres se les da mal manejar manos y pies a la vez y, qué pollas, a él le gusta llevar el rumbo de su vida y su automóvil. Y sí, conduzca usted, don Carlos, y yo a callar a pesar de que se equivoque de carril y se pierda al coger en la autopista una salida que no es. Lo que yo decía: patético» (Castro, 2008 [2010]: 66).

Clara reivindica su posición de mujer: «Otra Ley Sagrada que a ver quién inventó: Los polis no pueden tener miedo. Por qué. Es más: por qué las mujeres policía deben parecer Ángeles de Charlie y ser más duras que la teniente Ripley, a ver, por qué» (Castro, 2008 [2010]: 8).

Es interesante comprobar que las protagonistas no son las únicas mujeres profesionales que aparecen en las novelas. Giménez Bartlett manifiesta abiertamente que Petra no es feminista, sin embargo, crea un entorno con mujeres de perfiles profesionales distintos. «En la ficción, cualquier militancia me parecería peligrosa. Si Petra fuera estupenda y lo hiciera todo sin contradicciones, se resentiría de un cierto esquematismo. Yo procuro que en mis libros no se note que soy feminista, de izquierdas y que tengo 61 años» (Giménez Baartlett en Goñi, 10 de marzo de 2013: en línea). Castro también sitúa mujeres profesionales alrededor de las protagonistas, aunque con diferentes matices.

Petra se relaciona con juezas, con las que siente, en algunos casos, afinidad y un cierto aprecio. La jueza de menores Isabel Royo, que se relaciona muy bien con los policías. La jueza Flora Mínguez, de la que dice: «Teníamos la misma edad y no 
era la primera vez que coincidíamos en una instrucción. Siempre se había mostrado cordial conmigo y nos había dado facilidades de cara a la investigación, pero yo sabía que su fama de dureza no se debía a rumores y siempre la había tratado de manera formal» (Delicado, 2007 [2013]: 1497). También hay empleadas del hogar (Azucena, Julieta), asistente social, directora y funcionarias de prisiones, inversoras financieras (Laura, la madre de Mariana), periodistas (Ana Lozano, que se casará con Pepe, su segundo marido), otras agentes (Yolanda y Sonia), e incluso monjas, es decir, que abarca un amplio espectro de empleos.

Clara tiene que vérselas con una médica forense llamada Dolores (Lola), secretaria del juzgado, peluqueras y prostitutas de alto standing. En Y punto (2008) la mayoría de mujeres con las que se relaciona la subinspectora en su trabajo son prostitutas (de todas las clases sociales), aunque también interactúa con mujeres de clase alta que actúan de amas de casa, como su suegra.

Teresa Sinde, como propietaria de un restaurante de moda, tiene que conocer, a la fuerza, a muchas personas que están de paso en su local, a los que tiene que atender como anfitriona. Además, si se trabaja en un medio audiovisual donde la publicidad es importante hay que hacer un esfuerzo por mantener relaciones con diferentes tipos de profesionales. Pero estas personas (directivos, editores, directores de banco, etc.) no permanecen en el círculo de amistades de Teresa Sinde, la propietaria del «Barbantesa». La cocinera confiesa: «no son meros asalariados, son mis compañeros, cocineros como yo que me ayudan, de los que aprendo y a quienes respeto» (Castro, 2010: 60). Además, están Tomás, su cocinero jefe, y Estrella, su ayudante, secretaria, paño de lágrimas y lo que haga falta.

En el restaurante, Teresa es altamente competente, una cocinera de éxito, hecho que queda refrendado cuando le conceden el Premio Nacional de Gastronomía por «la originalidad de sus propuestas culinarias y la extraordinaria calidad de las materias primas» (Castro: 2010: 372). Sin embargo, debemos tener en cuenta que la misma Teresa confiesa que su éxito no es de ella únicamente, lo es de su equipo, sobre todo de Tomás, el jefe de cocina. La única de las tres protagonistas (Petra Delicado, Clara Deza, Teresa Sinde) que es reconocida personalmente siente reparos en aceptar este reconocimiento y reparte su éxito 
con su amigo. Afirma: «[En el Barbantesa] yo soy algo así como la máxima soberana de la colmena, una monarca que soporta su corona dejando que éste brille a la luz de los focos, leyendo discursos que no dicen nada [...]. Pero el presidente de este gobierno, el que manda de verdad, el respetado por todos es, por descontado, Tomás» (Castro, 2010: 62).

Un concepto que sobrevuela la vida de las protagonistas es el techo de cristal. Linda Wirth (2002) define este concepto en los siguientes términos:

El «techo de cristal» es un término acuñado en la década de los años setenta en los Estados Unidos para describir las barreras artificiales e invisibles, creadas por las actitudes discriminatorias así como por los prejuicios de las organizaciones, que bloquean a las mujeres en su intento de obtener puestos de dirección. El hecho de que este techo de cristal aparezca en el lugar de trabajo o en la política no es más que un reflejo de las desigualdades de género que existen en los ámbitos económico y social. Al haberse logrado una paridad educativa y ciertos cambios en las actitudes sociales en lo que se refiere al papel de la mujer y del hombre, se asumió en cierto modo que las mujeres se moverían con rapidez en la escalera profesional. Sin embargo, se ha demostrado que no es tan sencillo, sobre todo con respecto a los puestos de mayor responsabilidad, en los cuales el predominio de los hombres tiende a perpetuar el techo de cristal y, así, las mujeres se encuentran a menudo sin la experiencia empresarial apropiada que se exige en los puestos de dirección (Wirth 2002: 23).

Clara Deza y Petra Delicado pertenecen a la Policía Nacional. Actualmente, en el cuerpo hay 65706 efectivos (2016), de ellos 9000 son mujeres, según datos de la misma policía, divididos en las siguientes categorías: 21 comisarias, 150 inspectoras jefas, 644 inspectoras, 516 subinspectoras, 7386 cuerpo de policía (Policía Nacional, 8 de marzo de 2017: en línea). Tanto Giménez Bartlett como Mercedes Castro, conscientes de estos datos, sitúan a sus personajes en un ámbito laboral en el que independientemente de que hayan mostrado su valía, son consideradas en relación a sus compañeros, o ciertas conductas. Se evidencia, de este modo, el techo de cristal al que deben enfrentarse las protagonistas. Ni Petra 
ni Clara, parece que tengan posibilidades de ser comisarias. La subinspectora Deza se queja de que los compañeros no toman en consideración sus teorías y piensa lo fácil que sería dejarlo pasar.

¿Cómo puedes insistir en tus teorías rodeada de hombres que te niegan, que te quitan la razón dispuestos a refutarte que el cielo es azul? Déjalo, vete a casa, es tan fácil como levantarse de la silla y marcharse. A qué seguir, qué vas a sacar en limpio aquí, ¿sería capaz cualquiera de ellos de proponerte para un ascenso? ¿Podrían llegar a reconocer por una vez, sólo por una mísera y diminuta vez, que has hecho algo bien? (Castro, 2008 [2010]: 250)

Teresa, quizás por su propia historia vital, se queda en un margen estrecho de poder, su ventaja reside en que el restaurante es de su propiedad y el exotismo de sus platos atrae a esnobs que subrayan su éxito.

Hemos constatado que, a pesar de la profesionalidad que muestran, las protagonistas se encuentran con dificultades derivadas de su condición de mujeres en un espacio masculino. Cada una de ellas se enfrenta a situaciones de discriminación por parte de los compañeros y la discriminación sistémica de sus profesiones de diferentes maneras, en ocasiones se mimetizan con las costumbres masculinas, en otras se resisten e intentan poner en valor su identidad femenina. Pasemos a analizar cómo se produce esta asimilación y diferenciación de la conducta, comportamiento y valores masculinos.

\subsubsection{Masculinización vs feminización en la representación de las protagonistas}

Los feminismos se caracterizan de muchas formas diferentes: feminismos socialistas, feminismo cristiano, o feminismo del hiyab, entre otros. Victoria Sau (1981 [1989]) definió algunos de estos feminismos en su Diccionario ideológico feminista, pero los cambios sociales suman realidades nuevas al discurso feminista, que se convierten en nuevos feminismos. Todos los feminismos tienen un 
elemento común: el empoderamiento de los individuos, especialmente las mujeres a las que el patriarcado sitúa en una posición de inferioridad respecto al varón y limita su toma de decisiones. Celia Amorós (1997 [2000]) señala que el sujeto en el feminismo se construye en dos vertientes: una primera vertiente está relacionada con la emancipación de las restricciones de las sociedades patriarcales, entendiendo sociedad patriarcal como la «estructurada sistemáticamente en torno a la hegemonía masculina». La segunda vertiente impregna el proceso emancipatorio de valores ilustrados en los que «el feminismo se incardina a la concepción humanista del sujeto» con valores como autonomía, capacidad de reflexión, participación en el espacio público, etc. En este sentido, Amorós afirma que

[...] valores tales como autonomía, las capacidades reflexivas y críticas, la responsabilidad de un proyecto de vida individualizado que sólo se sabe viable en el ámbito del reconocimiento solidario, el adiestramiento para la interacción en estructuras de reciprocidad como constitutivo de toda posible vida moral, la participación en el espacio público, esfera del poder explícito y legítimo, como el cauce inolvidable y eficaz para la promoción de la propia potentia -en el sentido spinoziano-, de la incidencia activa en la configuración de las condiciones de la vida colectiva, que a todos afecta» (Amorós, 1997 [2000]: 24).

Sin embargo, no es el objeto de esta tesis tratar las características de cada una de estas formas de desarrollo del pensamiento feminista, tampoco es el objetivo establecer una taxonomía ajustada a cada una de las formas de feminismo. Nos decantamos por acudir a dos categorías amplias dentro de las cuales incluiremos el resto: feminismo de la igualdad y feminismo de la diferencia ${ }^{131}$. El feminismo de la igualdad plantea como objetivo que mujeres y hombres tengan los mismos derechos y obligaciones, para ello, adopta una postura crítica ante la división sexual. Es defendido por autoras como Victoria Sau (1981).

El feminismo de la diferencia, por su parte, una de cuyas representantes españolas más destacadas es Victoria Sendón, añade a los razonamientos de «igualdad» entre los sexos en que se apoyan socialistas y radicales, las de la

\footnotetext{
${ }^{131}$ Alicia Puleo (2005) plantea una idea similar sobre el enfrentamiento de los feminismos negros con el concepto de sororidad.
} 
diferencia reivindican simultáneamente aquellas cualidades femeninas que piensan pueden ser congénitamente propias de la mujer, tales como la sensibilidad, la intuición, una menor agresividad, etc. (Sau, 1981 [1989]: 129).

Por otra parte, el feminismo de la diferencia ha sido ampliamente contestado por el feminismo radical y el feminismo negro, entre otros, por motivos distintos, por el temor a que el hecho de exaltar las denominadas cualidades femeninas podría alienar a las mujeres y relegarlas, exclusivamente, a los roles que les han asignado las sociedades patriarcales de manera tradicional. Dolores Juliano (1998) expone:

Sin embargo, la idea unificadora del Feminismo de la Diferencia, según el cual existe un punto de vista femenino (generalizable a todo el colectivo de mujeres) específico y reconocible, ya había entrado en crisis anteriormente, a partir de la confrontación con el feminismo de las negras de EEUU., principalmente representadas por Angela Davis (1975), que no se sentían identificadas con el feminismo de las blancas académicas, de la clase media y alta. De hecho, no eran las únicas disconformes. Importantes sectores de mujeres se sentían excluidas de unas definiciones que no las tenían en cuenta: amas de casa, clases bajas, grupos étnicos. Las esencias que teóricamente unirían a todas las mujeres, en realidad las separaban profundamente (Juliano, 1998: 24-25).

Esto nos sirve para colocar a los personajes analizados en uno de estos macrogrupos o bien fuera de ellos, aunque sabemos que el desarrollo del feminismo es más complejo. Sonia Reverter (2012) resume la evolución histórica de las tres olas del feminismo, para que entendamos cómo definimos estos feminismos.

La primera ola viene marcada por las reivindicaciones de las sufragistas estadounidenses y británicas del siglo XIX. Estos primeros grupos pedían fundamentalmente el derecho al voto, así como los mismos derechos legales que los varones, sobre todo aquellos relacionados con la representación política y económica. La segunda ola se caracteriza por la coincidencia con otros movimientos sociales y por la mayor complejidad del análisis que las feministas hacen del patriarcado. La principal novedad radica en el concepto de género, que 
«ayuda a poner en evidencia las estructuras sociales, culturales, políticas, económicas, etc. que integran la compleja construcción de lo que llamamos patriarcado; y que es en definitiva del sistema de dominación de las mujeres a todos los niveles y espacios» (Reverter, 2012: 16). La tercera ola se desarrolla en los años 90 y se caracteriza por «avanzar y ampliar la agenda de liberación feminista» (Reverter, 2012: 16). Está caracterizada por una mirada crítica que pretende dar respuesta a por qué a pesar de la igualdad legal sigue existiendo una desigualdad de facto arraigada en el imaginario social y cultural. Esta reflexión crítica tiene respuesta mediante una diversificación de las voces del feminismo que acoge puntos de vistas relacionados con la clase, la raza o la sexualidad, entre otros. Esto añade elementos a la crítica feminista que complejiza las relaciones de poder.

Los estudios de género que se desarrollan desde los años sesenta (segunda ola) realizan análisis críticos de la representación y la situación de las mujeres en las sociedades en que viven. La sociedad patriarcal occidental, donde situamos nuestro análisis, establece una serie de estereotipos de género, femenino y masculino, que determinan comportamientos, actitudes, o qué tipos de trabajos pueden realizar, entre otras cosas. Grosman, Materman y Adamo (1989: 66) marcan las características de los estereotipos. El estereotipo masculino estaría representado por individuos independientes, fuertes, inteligentes, valientes, objetivos, racionales, activos, individualistas, duros, libres sexualmente, feos. Mientras el estereotipo femenino estaría representado por individuos, con valores opuestos, dependientes, débiles, menos inteligentes que ellos, temerosas, subjetivas, emocionales, pasivas, altruistas, tiernas, y blandas, sexualmente reprimidas, símbolos de la belleza.

Alicia Giménez Bartlett y Mercedes Castro, sin exponerla explícitamente, realizan una crítica a esta categorización de los géneros. Petra señala cómo esta división sexual es perversa, tanto para las mujeres como para los hombres. Fermín Garzón que es dibujado como el escudero de Petra Delicado, leal, apoya a su compañera, incluso cuando ella plantea una descabellada estrategia de investigación. Él suele mostrarse sensato, nos atrevemos a afirmar que se asemeja 
a Sancho Panza. Garzón intenta que Petra sea consciente de la realidad que él conoce muy bien por sus años de servicio en el cuerpo y por las circunstancias sociales que ha vivido antes de conocerla: dictadura, matrimonio sin amor, posición social desfavorecida... El subinspector Garzón ha vivido en una sociedad tradicional, con dos mujeres que cumplían una función de reproducción y de conservación de ésta, su mujer y su madre, dos beatas que seguían todos preceptos religiosos de manera estricta. Esto provocaba en el inspector una sensación de frustración e insatisfacción con su vida. Cuando era pequeño, su madre le decía que tenía suerte comparado con otros niños, él como hombre adulto sigue sin entender ese razonamiento.

Mi madre era muy religiosa. Me enseñó que nunca debía sentir demasiado placer. «Cuando te comas un buen trozo de carne, piensa que hay gente que no tiene nada que llevarse a la boca -me decía-: Cuando estés calentito en la cama acuérdate de los que no tienen donde dormir». Siempre cosas por el estilo, y si le contestaba: «Madre, no conozco a ningún necesitado», saltaba como si le hubieran picado y contestaba: «iPues los hay!, aunque sea muy lejos, en el Perú. En el mismo momento en que a ti se te deshace una onza de chocolate en la boca, en ese mismo momento, un niño pobre está muriéndose de hambre, en ese instante, dando el último suspiro, entregando el alma a Dios» (Delicado, 1996 [2013]: 146-147).

Su mujer era una mujer piadosa como su madre y planteaba el mismo tipo de argumentos, lo que provocaba desazón en Fermín, pero bien aleccionado desde la niñez nunca se atrevió a cuestionar la situación, a pesar de que su vida sexual era poco satisfactoria.

-Eso he querido pensar siempre para no volverme loco. Pero mi mujer era igual que mi madre, o peor, porque con mi madre no tenía que compartir la cama y con ella sí. Sus manías de limpieza, su beatería, su estupidez, sus remilgos. A saber por qué siempre le fui fiel. No se podía hacer el amor en viernes, ni en Cuaresma, ni por Navidad, porque era indecoroso estar haciendo «esas cosas» mientras nacía nuestro Salvador. Y cuando la operaron de los ovarios y no pudo tener más hijos, entonces argumentaba: «¿Para qué, Fermín, para qué vamos a estar juntos si Dios ya no nos quiere como marido y mujer?» No se imagina lo que es para un hombre aún joven y fuerte acostarse bien 
afeitado, con pijama limpio y agua de colonia para recibir siempre la misma respuesta (Delicado, 1996 [2013]: 146-147).

Petra, en cierto modo, se apena por el estricto sistema de roles al que Garzón ha estado sometido toda su vida. La reflexión de la inspectora considera que el patriarcado ejerce presión no solamente sobre las mujeres, sino también sobre los hombres.

¡Pobre Garzón!, el juego sempiterno de los roles sexuales lo había convertido en un inútil, en un ser tan incapacitado para organizar las cosas mínimas de la vida que tenía que pedir ayuda para lo primordial. La época gloriosa había sido mala para las mujeres, pero también para los hombres. Los tiempos habían cambiado, dejando a algunos mal preparados para lo que se avecinaba. Una broma pesada, ipobre Garzón! Incluso aquellos amores suyos tan a destiempo, tan deslumbrados e infantiles, eran también producto de su inadecuación anterior. Jamás se había planteado una separación de aquella esposa suya que tan desgraciado lo hacía. Y claro, ahí estaba ahora, divertido y halagado, paladeando como maná lo que hubiera tenido que ser plato de diario (Giménez Bartlett, 1997 [2013]: 315).

Marcos, el tercer marido de Petra, define a la inspectora como un compendio de cualidades que aparecen en el estereotipo femenino (sensible y atractiva) y el estereotipo masculino (inteligente y dura): «Eres encantadora, Petra, inteligente, dura pero sensible, atractiva» (Giménez Bartlett, 2007 [2013]: 151).

Petra, policía dura, se niega a tener pálpitos. La intuición policial que suele ser un valor en el género negro porque muestra la perspicacia del investigador aplicado a una mujer detective la colocaría en una posición irracional.

Únicamente después de pasado un tiempo me di cuenta de que se trataba de una premonición. Se me representó entonces la idea con toda claridad, y sentí deseos de proclamar a los cuatro vientos que de todo lo que estaba sucediendo yo había tenido un atisbo inicial. Pero nada hay más inútil que reivindicar el papel de Casandra por parte de una mujer. La gente está acostumbrada a que las mujeres pronostiquemos los problemas con mucha anticipación, y se cansa de escuchar, de cotejar las predicciones con lo que pasa después. Reconozco 
que es pesado andar siempre previendo las cosas malas. Admito también que los pálpitos tienen poca base científica y cuentan con escasa bibliografía a su favor, pero empíricamente están demostrados. No puedo encontrar otra explicación a que mi tendencia de aquella mañana melancólica se viera respaldada poco más tarde por un caso sin duda muy poco corriente ${ }^{132}$ (Giménez Bartlett, 2000 [2013]: 686).

Los personajes de Castro son más emocionales. Clara, incluso utiliza esta sensibilidad para construir sus teorías. Santi, su jefe, en un momento en que revisan el caso, le dice: "pero tampoco es para emocionarse. Antes teníamos dos simples muertos y ahora parece que hay algo más, sin embargo aún no se sabe qué y puede ser todo una paja mental tuya, una corazonada de poli sensible, y ya sabes que hay históricas meteduras de pata basadas sólo en corazonadas poco inspiradas» (Castro, 2008 [2010]: 163).

Uno de los aspectos que el sistema patriarcal impone a las mujeres es la culpabilidad, asociada a las características de los estereotipos. Petra la siente en diferentes momentos a lo largo de la serie. Uno de estos episodios le sobreviene cuando no puede atender adecuadamente a su hermana Amanda, que ha aparecido en su casa porque tiene que pensar qué va a hacer con su matrimonio. La inspectora de policía, al ver la vida de su hermana, vuelve a cuestionarse su propia forma de vivir y considera que tal vez tenga razón cuando le dice que está en un ambiente masculino que la aleja de su feminidad. Amanda le recrimina:

${ }^{132}$ El mito de Casandra surge en la literatura griega de la mano de Homero, que la menciona por primera vez aunque no la caracteriza con los atributos que ha llegado a nuestros días. Apolo se enamoró de Casandra, hija de los reyes de Troya (Hécuba y Priamo). Ésta le prometió que accedería a sus peticiones si le concedía el don de la profecía. Apolo le otorgó este don, pero Casandra no cumplió su promesa. Al sentirse engañada, Apolo castigó a la joven con una maldición: nadie creería sus profecías. Así sucedió en la guerra de Troya, aunque avisó de que el caballo de madera era una trampa nadie le creyó y la ciudad quedó destruida. Superviviente de este desastre fue entregada a Agamenón, hecho que selló su desgracia. A esta versión que nos ha llegado desde los relatos de Esquilo hay que sumar la versión de Eurípides, que cambia el don que Apolo otorga a Casandra de la videncia a la virginidad. Bartlett evidentemente hace referencia a la versión de Esquilo en su novela (Grimal, 1951 [1981]: 89-90). 
-¿Cómo has podido, delante de todo el mundo...?

-¡Pero, Petra! ¿Qué crees que hacían las matronas romanas cuando iban a los baños? Todo esto forma parte de una larga tradición.

-No entiendo nada, de verdad.

-Creo que has estado demasiado tiempo metida en contextos masculinos. Las mujeres decimos lo que sentimos, no hay nada vergonzoso en ello, ¿o sí?

-Vergonzoso no, pero la intimidad...

- La intimidad es un cuento para que todos nos aguantemos solos nuestras penas. No lo entendía. Era posible que mi hermana estuviera en lo cierto, pero yo hubiera sido incapaz de obrar así. ¿Demasiado contexto masculino, demasiada soledad? ¿Qué se ganaba callando, qué se perdía con una comunicación tan abierta? No lo sabía, pero yo prefería dosificar los datos sobre mí misma (Giménez Bartlett, 2000 [2013]: 741).

En el caso de Clara Deza la culpa en ocasiones le viene impuesta por parte de su suegra.

Y la suegra, mira tú qué mala suerte, y ahora mi niño, el pobre, histérico y preocupado y sin poder dormir por culpa de semejante resabiada que ni para darle un hijo va a servir al final, como si no le bastara con andar por ahí haciendo de marimacho. ¿Y sabes qué te digo?, que esas cosas no vienen así como así, que algo habrá tenido que tomar o hacer, tú ya me entiendes, para ahora, tan joven, tropezarse con eso. Porque no me dirás que es normal (Castro, 2008 [2010]: 8-9).

Otras veces, Clara se siente golpeada por la culpabilidad que ella misma se impone: «Si es que eres idiota, siempre intentando salvar lo desahuciado, empeñada en purgar por los pecados de los demás, culpándote de los males del mundo cuando sabes que no hay cura ni remedio» (Castro, 2008 [2010]: 14). Esta culpa llega por no resolver el caso o porque muere alguno de los testigos o porque en sus relaciones con los compañeros y jefes no sabe mantener una actitud menos empática, como el resto de sus compañeros. «Yo opino que, de ser bueno el soplo de nuestro confidente, la cantidad es demasiado elevada como para dejarla escapar y considerarnos responsables de lo que pueda matar o de lo que se pueda matar 
por ella. Yo, al menos, me sentiría culpable por más que me digan que los muertos no pierden sangre» (Castro, 2008 [2010]: 15).

Es curioso comprobar cómo tanto Petra como Clara sufren y no entienden el exceso de celo profesional que muestran los hombres en el trabajo. Entienden su labor como un servicio público y no están tan interesadas en ponerse siempre la medalla, prefieren que se reconozca su trabajo, pero aceptando éste como un trabajo en equipo: forenses, juezas/jueces, compañeros/compañeras de otros departamentos, etc. a los que elogian el trabajo.

Fermín está enfadado porque la prensa ataca la investigación que están llevando a cabo de las violaciones. Petra cansada del mahumor del subinspector le dice:

- ¡Basta, Fermín!, me tiene usted hasta los cojones con todo este asunto. No importa quién se haya apuntado los méritos. Para nada necesito que me restituyan el honor, ya ve a qué extremos puede llegarse por culpa del jodido honor. Si quiere usted adornarse el historial no tiene más que pasarse por las bolas la resolución del juez y dar su propia rueda de prensa. Ahí pone usted todas las cosas en su lugar, pero a mí ni me mencione, ¿entendido? (Giménez Bartlett, 1996 [2013]: 228).

Más adelante el pique se debe a que otro compañero se va a llevar el mérito en solitario del trabajo que han realizado entre todos. «Si Palafolls había encontrado algo, ¿por qué demonio se lo había guardado para sí? ¿Qué pretendía, colocarse él solo todas las medallas del mérito policial, o realmente se creía una especie de superagente?» (Giménez Bartlett, 1999 [2013]: 632).

Finalmente, aunque Garzón no puede entrar en esta especie de guerra de egos, ya tiene claro que la prioridad de Pera es el caso y «hacer justicia». Así, al darse una situación similar a la anterior, tienen una conversación sobre el tema:

—En el fondo, lo que vamos a sacar en claro es que Moliner y Rodríguez se llevarán todos los méritos del caso si dan con el final antes que nosotros. 
—QQuiere que le diga lo que eso me importa?

-Sí, ya sé, lo sé muy bien, inspectora. Tres carajos es lo que le importa, ¿me equivoco? (Giménez Bartlett, 2000 [2013]: 886)

La subinspectora Deza, por su parte, junta las piezas del puzzle y sugiere que un operativo. La idea es buena, pero claro, tampoco era tan difícil llegar a esa conclusión. La policía debe tragarse su autoestima y aceptar que en el organigrama ella es el último escalón y quien se pone las medallas son otros. «Como el inspector jefe Bores, tan justo él, tan ecuánime, tan a su disposición, señor comisario, ¡si el mérito ha sido sólo suyo!, y tú, niña, a ver, mueve ese culito del asiento y haz algo de utilidad, que yo voy a invitar a Su Excelencia a un aperitivo» (Castro, 2008 [2010]: 17).

Clara se muestra más segura de su condición de mujer que Petra, a pesar de que en ocasiones pueda tener dudas. En una discusión con Ramón defiende: «Vaginal. -Me niego a considerarlo como un insulto. Las mujeres somos vaginales, es lo propio, tenemos que serlo. Hombre convencional» (Castro, 2008 [2010]: 31).

Este cambio se relaciona, a nuestro juicio, con un cambio de actitud en las lectoras. Los datos señalan que las mujeres son grandes lectoras de todo tipo de literatura, como ya hemos visto con anterioridad. Durante mucho tiempo se les asignó a las mujeres, casi en exclusiva, la novela romántica, sin embargo, la chick lit, que se inicia en los noventa, enseña a las mujeres que pueden ser protagonistas y, además, que pueden leer sobre lo que desean, necesitan, o sobre los problemas que tienen Este nuevo género se inaugura con El diario de Bridget Jones (Helen Fielding, 1996), Isabel Santaulària i Capdevila (2005a) lo define como un «producto post-feminista por excelencia caracterizado por centrar sus argumentos en las historias, deseos, temores, relaciones, amistades, etc. de mujeres independientes que han alcanzado sus objetivos profesionales; todas ellas siguen defendiendo el ideario de que la felicidad para la mujer se consigue, sólo, en pareja» (Santaulària i Capdevila, 2005a: 145). En realidad lo que favorece es que las mujeres se vean reflejadas y sean protagonistas de la historia. Esto se extiende a otros formatos como el cine y la televisión (Sexo en Nueva York, 1998-2004), y a otros géneros. De ahí que consideremos que, a principio de siglo, las mujeres estén 
acostumbradas a ser los personajes de la historia y no estén dispuestas a renunciar a ello. La novela negra incorpora estos elementos y nos presenta investigadoras que tienen bultos en el pecho, que acaban de dar a luz y no saben cómo gestionar la nueva situación.

Teresa Sinde, por su parte, es un personaje completamente diferente. Se trata de la mujer fatal que, cual mantis depredadora, es capaz de devorar al macho que se le pone por delante. La culpabilidad que puede sentir la maneja mediante la creación de los platos que sirven de título a cada uno de los capítulos. Sin olvidar que, siendo muy consciente de lo que ha sufrido por parte de una madre represora y un entorno hostil, no está dispuesta a continuar siendo una víctima. Al menos, esto es lo que sucede en la superficie, porque lo cierto es que cada una de sus «recetas» la dejan agotada física y, sobre todo, emocionalmente, como demuestra el hecho de que Teresa necesite el apoyo de su amiga-secretaria, Estrella, y se apoye en ella tanto en casa como fuera de ella. Muchas mañanas, se pasa por el palacete donde reside la cocinera para ver cómo está y asegurarse de cómo había transcurrido el día anterior o repasar la agenda del día. «Como siempre, Estrella me atrapa delante de la primera, la mejor taza de café del día. Al tanto de todo, no en vano se jacta de ser la mejor informada [mañana siguiente a recibir un puñetazo por meterse en medio de una agresión a una modelo clienta del restaurante]» (Castro, 2010: 153). En el Barbantesa, el restaurante de Teresa, también es una especie de figura omnipresente, lleva las cuentas del local, el marketing, coordina las relaciones públicas y está pendiente del estado de ánimo de Teresa.

Más tarde se presentará Estrella, y en la cocina superpoblada de hormigas con delantal que preparan lo necesario para servir medio centenar de comidas se cruzará una mirada con Tomás y decidirá, ante la seña disuasoria de él, vigilarme desde lejos, no olvidarse de pasar en algún momento por mi lado para comprobar qué tal nos está saliendo el invento [el plato del día que está creando Teresa]. (Castro, 2010: 338).

Tras la confianza que aparenta Teresa hay una mujer con inseguridades y miedo a la «bestia negra de su interior», de ahí que busque rodearse de amigos en los que apoyarse (Tomás en la cocina, Estrella en todos los ámbitos de su vida). 
En cuanto a si el personaje presenta actitudes tradicionalmente asignadas a las mujeres o más masculinizadas, lo cierto es que Castro concluye la novela haciendo que la cocinera le pida a Germán, de forma literal: «Sácame de aquí» (Castro, 2010: 438). Mantis narra la historia de Teresa Sinde (cocinera de éxito, presentadora de un programa de cocina y escritora de libros de cocina) que mantiene breves relaciones con hombres que desaparecen: un prometido que la dejó, el hijo de un policía que la persigue, un joven que trabaja en un programa de televisión... A pesar del éxito de su vida, Teresa se siente sola, sobre ella se ciernen «pensamientos oscuros»y, a pesar de sus intentos, no consigue apagar su «voracidad». Torturada por una niñez infeliz bajo la sombra de una madre autoritaria las noches de insomnio intenta calmar su ansiedad creando sabrosos platos que servir a la mañana siguiente en su restaurante mientras busca a su «alma gemela» entre sus amantes. No será hasta el final de la novela cuando parece que lo encuentre en un periodista que la ha estado siguiendo a lo largo de la historia cuando huyen juntos y Teresa cree tener controlado su gran apetito. Este final asimila la historia a un cierre clásico en el que el príncipe azul salva a la princesa, sin embargo, en este caso, es Teresa la que ha escogido a Germán para huir porque: «en cuanto a mi hambre, finalmente estoy tranquila. Creo que la podré dominar. En todo caso sé que si me acucia, no importa dónde me encuentre, siempre puedo volver a cazar» (Castro, 2010: 441). Es decir, Teresa Sinde finaliza su camino empoderada de alguna forma.

Estas protagonistas se ajustan mejor a los nuevos feminismos de la diferencia en los que las mujeres pueden poner en valor sus intereses, incluso aquellas conductas que se han considerado siempre como femeninas.

Este fenómeno no se circunscribe sólo a las protagonistas femeninas, también los nuevos investigadores presentan conductas más próximas a la ética de los cuidados que tradicionalmente asignamos al género femenino. Así lo demuestra el personaje de la Trilogía de la Ciudad Blanca de Eva García Sáenz de Urturi (El 
silencio de la ciudad blanca, 2016 y Los ritos del agua, 1997) ${ }^{133}$, el inspector Unai López de Ayala.

La primera entrega de la Trilogía de la Ciudad Blanca deja patente la existencia de diferentes masculinidades. El protagonista de la historia que transcurre en el presente, Unai López de Ayala, representa a una nueva masculinidad más igualitaria. Esto se puede rastrear en la relación que mantiene con su compañera, su concepto sobre la paternidad ${ }^{134}$, la forma en que manifiesta sus sentimos, etc. Mientras que el protagonista de la historia que transcurre en el pasado, el rico industrial Javier Ortiz de Zárate, encarna una masculinidad violenta y pendenciera que avasalla a quienes le rodean cuando no actúan como a él le conviene, y que entiende la paternidad como una posesión ${ }^{135}$. El resto de personajes masculinos se posicionan cerca de una y otra masculinidad. En este sentido, el afable abuelo del inspector López de Ayala representaría, en un momento poco propicio para ello, una masculinidad «distinta», muy apegada a la tierra y el misticismo que de ella emana. Es tranquilo y comprensivo, además, ha criado a dos niños (Unai y su hermano Germán). El abuelo, que fue alcalde de la aldea, tuvo que enfrentarse a algún hombre violento que maltrataba a su esposa.

\footnotetext{
${ }^{133}$ Cabe señalar que la autora tiene una saga de novela de ciencia ficción titulada la serie de La saga de los Longevos (2012), Los hijos de Adán (2014), Paisaje a Tahití (2014). El éxito de la primera novela, autopublicada en amazon, se debió al boca a boca y de ahí surgió la primera saga y, seguidamente, la Trilogía de la Ciudad Blanca. García Sáenz de Urturi, meticulosa con los detalles y la documentación para sus novelas, estuvo dos meses en una academia de policía realizando cursos de inspección técnica ocular y revelado de huellas.

${ }^{134}$ Unai y Alba/Blanca se encuentran para correr y el inspector se da cuenta que lleva ropa deportiva nueva. "-He estado embarazada unos meses y quería recuperar el tono muscular. No me esperaba aquella respuesta, apreté la mandíbula, alejando fantasmas. Vaya... Tiene mérito -fui capaz de decir.

-Estarás agotada con el bebé, seguro que no te deja dormir por las noches. Ahora te reincorporas al trabajo y además te preocupas por estar tonificada. [...] -No, no es lo piensas. Estuve embarazada hasta los siete meses. El... el bebé se malogró. [...] -Mi hijo no era viable. Cada día que crecía, sus huesos se rompían dentro de mi útero y estaba sufriendo mucho. Me hicieron una cesárea programada, sólo vivió unas horas. No soporto verme el vientre, no soporto tener todavía cuerpo de embarazada» (García Sáez de Urturi, 2016: 117-118).

135 Lo importante es el apellido y la herencia. Así se puede comprobar cuando el médico le comunica que su esposa está embarazada de gemelos. Javier comenta que sus tíos eran gemelos, a lo que el doctor responde que ya tiene los hombres si son varones. Ofendido: «¿Y qué otra cosa iban a ser si no, doctor? No me fastidie con pronósticos agoreros. Serán varones, como su padre» (García Sáenz de Urturi, 2016: 370).
} 
La respuesta de éste fue acercarse a casa de éste y darle una paliza, las agresiones cesaron.

Es importante observar que Unai no se muestra violento con los testigos y que va a hablar con su abuelo, en cierto modo, a pensar en la naturaleza para despejar dudas. Dolores Redondo también utiliza la cosmogonía del norte para la Trilogía del Baztán. Así vemos que tanto Amaia Salazar como el inspector López de Ayala manifiestan una conexión mística con el entorno natural donde se hunden las raíces de sus antepasados ${ }^{136}$. Sin embargo, en este caso, las guardianas de la Mari no son mujeres (como sucede en Redondo) sino que es el abuelo, un hombre, apuntando a masculinidades alternativas. Amaia Salazar, la inspectora de la Policía Foral de Navarra, tiene una red social de mujeres en su entorno personal, pero en su ámbito laboral está rodeada de hombres que se ajustan a diferentes masculinidades. Sólo tomaremos dos de los personajes como ejemplo: el subinspector Fermín Montes, que se enfrenta a Salazar porque considera que ocupa el puesto que él debería ocupar por una cuestión de política, y. el ayudante de la inspectora, Jonan Etxaide

Fermín Montes siente que está siendo discriminado porque los programas de igualdad de oportunidades y la tendencia a lo políticamente correcto lo relega a él con años de experiencia para beneficiar a una mujer, Amaia. Para conseguir su respeto, la inspectora se pelea con éste a puñetazos en un callejón. En este sentido, vemos que Montes representa una masculinidad tradicional que contagia a Salazar.

136 En algunos aspectos se aproximan al realismo mágico, esta es tal vez, una de las mayores diferencias que existe entre los personajes de Alicia Giménez Bartlett y Mercedes Castro y las nuevas escritoras de género negro. Las nuevas autoras incluyen en sus relatos elementos imaginarios o irreales como algo del día a día. Amaia Salazar, por ejemplo, tiene conversaciones con su mentor del FBI en Nueva Orleans, a pesar que éste está desaparecido. Unai López de Ayala ve a su abuelo en el momento de su accidente, a pesar de estar a kilómetros de distancia. Delicado y Deza son dos policías de ciudad y sus herramientas de trabajo están ancladas en un entorno urbano y ligadas a la realidad. Parece que en este entorno resulta más difícil introducir esas nuevas masculinidades, a pesar de lo cual, en los siguientes epígrafes veremos los pequeños cambios que se introducen en el modelo de masculinidad que se plantea en las novelas de Giménez Bartlett y Castro. 
Por otra parte, Etxaide es presentado como

[...] un policía con una gran formación y se siente incómodo en los escenarios del crimen o en la sala de autopsias, hecho que toman a chanza algunos de sus compañeros. Su homosexualidad no se trata a lo largo de la serie, únicamente es mencionada por alguno de sus compañeros, que manifiesta sentirse incómodos (Valero Valero, 2015: 94).

En este caso, la competencia de Jonan también ayuda a la policía a realizar un mejor trabajo. En este ejemplo, Redondo no se centra en la orientación sexual del personaje aunque lo construye con características diferentes a las que generalmente se asigna a los detectives de novela negra (incluso a las mujeres). No ejerce violencia, tiene una formación amplia, siente rechazo por la parte menos intelectual del trabajo y es gay. Un personaje con cuya homosexualidad no se satiriza, no se juega al humor, sino que se representa integrado y en igualdad de condiciones, a priori, con el resto de compañeros.

Es decir, la responsabilidad de conseguir la igualdad y justicia social ya no recae de forma exclusiva sobre las mujeres, sino que las nuevas masculinidades también se ven involucradas. Algo que Petra trabaja con Garzón y Marcos, así como con otros de los compañeros sexuales que ha tenido a lo largo de la serie.

En este apartado hemos comprobado cómo las protagonistas de las novelas analizadas, aunque adoptan, en ocasiones, actitudes que se consideran propiamente masculinas, suelen reivindicar también una parcela de identidad propia por el hecho de ser mujeres.

Así pues, podemos decir que los personajes femeninos protagonistas en el corpus estudiado son profesionales que se mueven entre la contradicción de asumir comportamientos que, tradicionalmente, se le han asignado a los hombres, lo que hace que las vean como masculinas, y la reivindicación de los valores que tradicionalmente se les han asignado a las mujeres. Esto las convierte en personajes más complejos y reales. Son personajes que mantienen relaciones sociales con hombres y con mujeres. Abordamos, a continuación, cómo son estas relaciones sociales, tanto en el ámbito laboral como social, con las mujeres. 


\subsubsection{Representación de la maternidad en Alicia Giménez Bartlett $y$ Mercedes Castro}

La división de roles, en las sociedades patriarcales, determina a las mujeres por la posibilidad de la maternidad, asignándoles como su principal función la reproductiva. Los feminismos, por su parte, reivindican la maternidad como un hecho voluntario cuya responsabilidad debe ser compartida. En el ámbito laboral, la maternidad es uno de los hándicaps más importantes, provoca el rechazo del empresariado, que lo ve como una carga, y supone un tiempo con currículums en blanco que penaliza en el ascenso en algunas carreras profesionales.

El imaginario colectivo de las sociedades patriarcales establece la maternidad como un elemento indisociable de la condición femenina. Las mujeres, según esta teoría, tienen «instinto maternal», es decir, sienten deseo de ser madres y tienen un vínculo especial y «natural con sus hijos». Elisabeth Badinter (1981) hace una revisión de este concepto de la maternidad:

Hemos concebido durante tanto tiempo el amor maternal en términos de instinto, que de buena gana creemos que se trata de un comportamiento arraigado en la naturaleza de la mujer cualquiera sea el tiempo y el espacio que la rodean. Creemos que al convertirse en madre la mujer encuentra en ella misma todas las respuestas a su nueva condición. Como si se tratara de una actividad preformada, automática y necesaria que sólo espera la oportunidad de ejercerse (Badinter, 1981: 12).

Esta lógica patriarcal que surge en el siglo XVIII se reforzará en el XIX con la aparición del concepto del «ángel de hogar» y la idea de que la mujer debe cuidar de su familia y supervisar la educación de sus hijas $y$, en menor medida, de los hijos. El instinto maternal se transforma en «amor maternal», que supone una mayor exigencia para las mujeres, pues si no ejercen la maternidad según los valores que establece la sociedad patriarcal son consideradas «malas madres», lo que las hace susceptibles de ser castigadas. Las mujeres se convierten en reproductoras de los principios patriarcales. 
En la actualidad, gracias a la facilidad de comunicación que ofrecen las redes sociales, han aparecido numerosos blogs y microblogs de madres que cuentas sus experiencias y rompen con la carta de naturalidad que se le otorga a la maternidad en las sociedades patriarcales ${ }^{137}$. Pero estos argumentos no son nuevos. Será Simone de Beauvoir (1949 [2011]) la primera en señalar que la condición maternal no es natural sino social, y afirma:

Esta obligación no es nada de natural: la naturaleza no podía dictar una conducta moral, que implica un compromiso. Engendrar es asumir un comportamiento; si la madre luego lo olvida, comente una falta contra la existencia humana, contra una libertad; pero es algo que nadie puede imponer. La relación de los padres con los hijos, como la relación entre esposos, debería ser libremente deseada. Ni siquiera es cierto que el hijo sea para la mujer la mejor forma de realizarse...» (Beauvoir, 1945 [2011]: 678).

Por otra parte, Beauvoir (1945 [2011]) razona que si la maternidad no es natural, no hay posibilidad de que haya madres desnaturalizadas, pero sí buenas y malas madres, ya que esa calificación dependería de si la maternidad se ajusta a las normas que la sociedad establece para que las sigan las buenas madres.

El segundo prejuicio que se deduce inmediatamente del primero es que el hijo encuentra la felicidad segura entre los brazos maternos. No puede haber madres «desnaturalizadas», porque el amor materno no tiene nada de natural, pero precisamente por eso existen las malas madres. Una de las grandes verdades que ha proclamado el psicoanálisis es el peligro que constituyen para el niño los padres «normales» (Beauvoir, 1945 [2011]: 678).

Beauvoir desnaturaliza «lo natural», y transforma la maternidad en algo extraño a la condición de mujer. Sentencia que el deseo femenino es más complejo que la definición que dan las sociedades patriarcales de éste, la maternidad es ambigua y contradictoria.

Autoras feministas españolas siguen la misma línea de argumentación, por ejemplo, Victoria Sau (1995) y Dolores Juliano (1998) sostienen la necesidad de

\footnotetext{
${ }^{137}$ Algunas de estas webs con millones de visitas en todo el mundo son: El club de las malas madres (https://clubdemalasmadres.com/. Fecha de consulta: 21 de marzo de 2017), y No soy una drama mamá (https://nosoyunadramamama.com/. Fecha de consulta: 21 de marzo de 2017).
} 
desnaturalizar la maternidad, ya que la idea del instinto maternal determina la identidad de las mujeres. Para cuestionar esta idea ambas autoras hacen un recorrido histórico del concepto demostrando que el instinto maternal y la maternidad son funciones construidas socialmente de manera diacrónica (a lo largo del tiempo) y sincrónica (diferentes culturas en un mismo momento).

Nuestras autoras se posicionan ante la maternidad de diferentes maneras. Petra Delicado tiene sentimientos ambivalentes. Petra, al inicio de la saga, se ha decidido por la soledad, aunque se cuestiona en ocasiones su elección:

\begin{abstract}
Observé a una elegante ama de casa más o menos de mi edad que entraba distraída en una tienda de ropa para niños. ¡Naturalmente, eso era la felicidad, sentarse a ver cómo le crecen los dientes a tus hijos en vez de andar como una perdularia intentando averiguar por qué les cortan la polla a los demás! Mi elección vital había sido desacertada, aunque resultara un poco tarde para remediarlo (Giménez Bartlett, 1999 [2013]: 512).
\end{abstract}

Ella y su compañero, Fermín Garzón, hablan de lo pesado que es criar a unos hijos ${ }^{138}$. Sin embargo, en la línea de literatura mainstream en la que se enmarca esta serie, la inspectora acaba siendo madre «por poderes». Su tercer

\footnotetext{
${ }^{138}$ El subinspector Garzón tiene un hijo que vive y trabaja en Estados Unidos y con el que no tiene mucho trato. El hijo, empleado de un hospital de prestigio, se muestra displicente y arrogante con su padre, al que no muestra cariño. De hecho, en un momento dado, Garzón sentencia: «mi hijo es gilipolla» (Giménez Bartlett, 1997 [2013]: 247). Fermín está harto de la actitud que mantiene su hijo durante las dos semanas que está de visita en Barcelona y en la que constantemente le da consejos sobre alimentación, ejercicio... Este comportamiento le recuerda al subinspector la conducta de su primera mujer, que actuaba siempre con prudencia, lo que le provocaba infelicidad e insatisfacción. En una de las conversaciones con Petra sobre este asunto se pregunta ¿qué sabe su hijo sobre la vida? "Qué sabe de cómo su padre se ha roto el culo en un oficio tan duro como éste para que él estudiara. Qué sabe de lo absolutamente insoportable que fue su madre para mí. ¿Ha visto acaso una décima parte de las cosas que yo he visto: drogadictos, putas envilecidas, escorias humanas, cadáveres anónimos? ¡Presidente...! -Lo que dice no es razonable, Garzón, justamente usted ha luchado para que él tuviera otras perspectivas. -¡Bueno, pero que se entere de que hay cosas distintas en el mundo, gente puteada, jodida, tíos que nunca han podido salir de donde estaban! ¡Y sobre todo que me deje en paz, comeré todos los callos que quiera, y morcillas, y huevos fritos con mucho aceite!» (Giménez Bartlett, 1997 [2013]: 427). Finalmente el hijo de Garzón regresa a su vida, a kilómetros de distancia de su padre, con una nota en la nevera. La segunda visita que realiza Alfonso a su padre es para presentarle a su novio. Esto supone un shock para el subinspector. Desarrollaremos este aspecto en el epígrafe Representación de la sexualidad de las protagonistas en la novela negra de Alicia Giménez Bartlett y Mercedes Castro.
} 
marido tiene cuatro hijos. Por otro lado, Yolanda, la joven agente que la ayuda en alguno de sus casos, también se queda embarazada y, aunque en principio cree que será un freno para su carrera, no le hace saber cuáles son sus reservas sobre su estado.

El ideal de abnegación del estereotipo de mujer-madre elaborado por Hélène Cixous no puede corresponder al de una persona porque remite a un ser sin existencia propia. La mística de la mujer-madre encubre la realidad de que las mujeres que renuncian a todo por la maternidad y el matrimonio son justamente las que más decepcionadas y tiránicas se muestran después. El altruismo que se predica a las mujeres es impracticable, ya que implica la negación de propio yo. El amor no puede ser identificado con ese sacrificio sin pervertirse. La mujer exige la seguridad a cambio de su autonegación en el matrimonio. Pero entonces, realiza un comercio, no un sacrificio. Incluso peor, se trataría de un engaño porque nunca ha tenido un yo propio. Ésta será la situación, señala la autora, mientras la subsistencia de la mujer depende del matrimonio (Puleo, 2005: 26).

Giménez Bartlett modifica, poco a poco, la opinión de Petra respecto a la maternidad. Esta transición comienza en Serpientes en el paraíso (2002), aunque es una maternidad en la que no se incluye la paternidad. Nina Molinaro (2016) considera que para desarrollar el concepto de maternidad en la saga de Petra Delicado resulta fundamental que la inspectora y Garzón no sean pareja, ni sientan ninguna atracción sexual mutua: «Her entanglement with the performance of conventional femininity gets an unlikely boost from the fact that she is neither attracted to nor involved with a male romantic partner for the duration of the case» (Molinaro, 2016: 115).

De hecho, las apariencias sobre la maternidad en esta entrega llevan a nuestros protagonistas a hablar de la maternidad como un asunto «pequeñoburgués» cuando se encuentran con que la cuartada de una de las sospechosas está relacionada con un tratamiento de fertilidad que parece no importarle a su marido. En este sentido: «Sex seems to be off limits for Petra because, within the logic of Serpientes en el paraíso, it could facilitate pregnancy and childbirth, as opposed to desire and pleasure» (Molinaro, 2016: 115). 
Y es que la inspectora observa que las familias perfectas de la urbanización perfecta no lo son tanto, y se ajustan a una realidad familiar tradicional en cuanto a las funciones de madres y padres.

When she imagines parenthood, her dream never includes the requirement of paternity. Fathers are described as distracted, selfish, and superfluous. «Good» mothers care for their children at home, whereas «good» fathers spend their days at invisible offices and are tangential to child care and the emotional needs of their wives and children ${ }^{139}$. Although this dynamic has infused other novels in the series, the narrator-protagonist has, until the present case, eschewed women's work in favor of the resolutely masculine realm of police work. (Molinario, 2016: 115).

Petra reconoce sus sentimientos frustrados de ser madre en esta quinta entrega, a pesar de que anteriormente ya se cuestiona qué posición puede tener la maternidad en la vida de una mujer. En Mensajeros de la oscuridad (1999) ve a unas amas de casa y piensa:

Observé a una elegante ama de casa más o menos de mi edad que entraba distraída en una tienda de ropa para niños. ¡Naturalmente, eso era la felicidad, sentarse a ver cómo le crecen los dientes a tus hijos en vez de andar como una perdularia intentando averiguar por qué le cortan la polla a los demás! Mi elección vital había sido desacertada, aunque resultara un poco tarde para remediarlo (Giménez Bartlett, 1999 [2013]: 212).

En Serpientes en el paraíso (2002), al ver las niñas y niños de estas familias que intentan quedarse embarazadas, pero que luego dejan el cuidado de sus hijas e hijos en manos de mujeres inmigrantes mal pagadas ${ }^{140}$.

\footnotetext{
139 «Rosa y Mateo Salvia tiene problemas para tener hijos, aunque parece que a ella le parece que es una ventaja, así se pude dedicar a su carrera profesional» (Giménez Bartlett, 2002 [2013]: 992), sin embargo han intentado varias tratamientos (no quieren utilizar la inseminación artificial ni la adopción). Tras la entrevista con Rosa, la inspectora deduce: «Bajo la apariencia férrea de una mujer de negocios llena de sentido práctico palpitaban los más primarios instintos de la maternidad. El marido, frívolo y contento con su suerte, no quiere ni oír hablar de más pruebas de fertilidad. Entonces ella acude sola al hospital, pero no quiere que nadie sepa de su debilidad» (Giménez Bartlett, 2002 [2013]: 1048).

${ }^{140}$ «Sin duda, las criadas tenían su propio mundo paralelo en «El Paradís». Eran amigas, se comunicaban, libraban sus luchas de preponderancia o poder según la nacionalidad y se hacían confidencias sobre las familias para las que les había tocado trabajar. Me habría encantado meter la nariz allí» (Giménez Bartlett, 2002 [2013]: 957).
} 
Petra reflexiona junto a Garzón:

- Le gusta a usted esa niña, ¿eh, inspectora?

—Es mona —dije en tono casual.

- ¿Por qué no se casa otra vez y tiene un bebé? 0 incluso puede seguir sola y adoptar a una niña china. Ahora eso es una cosa muy corriente. [...]

- [...]. De todos modos le advierto que sólo pretendía que usted fuera feliz.

— ¿Y quién coño le dice que quiero ser feliz? Me siento perfectamente siendo desgraciada, estando frustrada y puteada. ¿No se había dado cuenta? (Giménez Bartlett, 2002 [2013]: 1010).

Observamos en esta conversación que el modelo de maternidad está cambiando. Fermín sugiere a su compañera que sea madre sola. Aunque la pareja continúa con el argumento iniciado desde la primera entrega de la serie de que la felicidad y la maternidad no son sinónimos. Cuando conoce a Marina (Nido vacío, 2007), la hija de su tercer marido, es cuando entra en la lógica de la maternidad. Ya no sólo porque ella misma es madre a tiempo parcial, sino porque en Italia se encuentra con Gabriella, una carabiniera recién incorporada después de una baja por maternidad que le hará tomar el pulso de lo que significa ser madre desde otro punto de vista, aunque las conversaciones sobre el tema estén plagadas de estereotipos y prejuicios. El isppetore Abate presenta a su subordinada como una gran profesional, primera de su promoción, que domina la informática, es máster en criminología y cinturón negro. Pero «anda preocupada» porque acaba de ser madre y ha dejado al bebé con la niñera por primera vez. El inspector italiano comenta: «Como mujer ya sabrá de estas cosas. Las mujeres cambian después de ser madres, pasan una época fieras con la sociedad y sólo son dulces con su hijo. Estuve a punto de decirle que aquello me parecía una soberana gilipollez pero me contuve» (Giménez Bartlett, 2013: 100). A la hora de la comida, Gabriella llama a la niñera para ver cómo está el niño y Petra tiene que ver cómo una mujer capaz hace aquello que ella criticaba en sus compañeras al principio de la serie, y siendo una policía a la que puede admirar por su profesionalidad.

Pero es que Petra ahora también es madre y tiene que pelearse con cuestiones como la culpa. Su viaje a Italia es inesperado, y la inspectora debe lidiar 
con el enfado de Marina (su hijastra) por no haberse despedido de ella antes de irse. En la acostumbrada conversación diaria que tiene con Marcos mientras está en Italia comentan esta situación: «-Marina está muy enfadada contigo. Dice que no te despediste de ella ni de los chicos. -Espero que le contaras que tuve que irme con precipitación. -Para que se quedara más conforme le dije que, prácticamente, tampoco te habías despedido de mí» (Giménez Bartlett, 2013: 114).

Así, aunque no lo quiera reconocer, queda inmersa dentro de la dinámica que la sociedad patriarcal asigna a las mujeres por su capacidad para ser reproductoras. Petra se resiste a la maternidad, a pesar de todo, y comenta con Abate:

¡Ah, no estaba dispuesta a ceder frente a las debilidades maternales! Justamente el día anterior lo había comentado con Gabriella, como aviso de navegantes. Las chicas actuales tienen su primer hijo a los treinta y tantos e inmediatamente autogeneran la conciencia de que la sociedad les debe una especie de gratitud. ¡Ah, no!, conmigo pinchaban en hueso. Parir siempre me había parecido una actividad femenina ancestral y cotidiana; de modo que no veía ninguna necesidad de tratar a las neomadres como si fueran una especie en extinción (Giménez Bartlett, 2013: 140).

También se molesta Petra cuando Garzón, en un gesto de sobreprotección, pretende que Gabriella se quede fuera durante el operativo, porque es madre y puede ser peligroso, ¿también se quedan fuera quienes han sido recientemente padres? A pesar de que los prejuicios del estereotipo proliferan en esta situación lo cierto que es hay un fenómeno de contagio entre Petra y Gabriella. La policía italiana le confiesa: «- ¿Ha visto, inspectora? He comprendido que usted tenía razón, el hecho de que tengas un bebé no puede convertirse en el centro de tu vida» (Giménez Bartlett, 2013: 153).

Sin embargo, la inspectora de policía no tiene que justificarse sólo en Italia. En España, cuando habla con Yolanda y Sonia, sus subalternas, también debe hacerlo.

Lo desenvolvió con extrañeza y casi se echó a llorar al descubrir un pijama de bebé estampado en manchas de jirafa. 
-¡Dios mío, inspectora, cómo se lo agradezco! Mucho más viniendo de usted.

- ¿Eso qué significa, que tengo fama de Herodes femenina?

-No, en absoluto, es que me he expresado mal.

Sonia intentó sacarla del apuro metiendo la pata según su costumbre.

-Yolanda quiere decir que a usted los niños ni fu ni fa; como no ha tenido hijos propios...

-Tampoco hace falta criar un cerdo para que te guste el jamón -dije con mala uva (Giménez Bartlett, 2013: 170).

Mientras Petra tiene sentimientos ambivalentes con la maternidad, los hijos de Marcos (su tercer marido) la adoran, tal vez porque les hace gracia que sea policía y les cuente algunas cosas de sus casos, tal vez porque los trata como personas inteligentes, sobre todo, a su pequeña Marina. La inspectora no sabe qué puede regalar a la niña, así que recordando que hace danza y habían estado hablando de la danza contemporánea, le regala un libro sobre la vida de Isadora Duncan, no sin preguntarse si será lo mejor. «¿Y si le daba por volverse alocada y pasional tras leer el libro sobre Isadora? ¿Tendría eso una influencia nefasta en su formación, sería yo la culpable, me perseguiría por los siglos la madre de Marina con un bate de béisbol en la mano para darme mi merecido?» (Giménez Bartlett, 2013: 219). Marina está encantada con su libro hasta que se lo incauta su madre por considerarlo inapropiado. El equilibrio entre todos los miembros de una familia con múltiples madres e hijos resulta, a vece, complicado, Petra lo verbaliza en los siguientes términos: «pensé, la obligación de ser correcta con los hijos de Marcos estaba pesando demasiado sobre mí. ¡No sería yo quien se volviera intransigente por causa de un decálogo moral que en el fondo detestaba en su mayor parte! Mi conciencia estaba tranquila» (Giménez Bartlett, 2013: 219).

De hecho, es interesante cómo la vida de Petra cambia con su matrimonio y los niños. Con Marcos siente que puede ser independiente, su último marido parece entender que el trabajo es importante para ella, sin embargo, cuando está trabajando le presiona si está fuera o se pierde, o se olvida de alguna cosa. Al mismo tiempo, cuando se van a ir de vacaciones, se tiene que llevar Petra sola a los 
niños porque él tiene que quedarse con un proyecto importante. En un primer momento no reacciona, luego piensa: «Mi relación con los chicos era buena; aunque, a decir verdad, nunca habíamos estado solos durante un tiempo prolongado y fuera de la casa habitual. Aquella novedad me provocó cierta alarma. De cualquier manera, ¿qué podía hacer si no era aceptar? Y acepté » (Giménez Bartlett, 2015: 186).

Esto demuestra que la evolución de Petra se dirige a un modelo de maternidad tradicional una vez casada con Marco, a pesar de que ella no es la madre biológica e intenta no involucrarse para no crear problemas familiares (madres biológicas, hija-hijos, padre). Como el arquitecto ya había acordado la fecha en la que tendría a su hija e hijos, la inspectora es la que carga con la responsabilidad de llevar de vacaciones (cuidar) a los hijos de su marido. «-He pensado que busquemos un hotel, el que te apetezca a ti, y que te quedes esa semana con ellos en la playa. Estaréis mejor que aquí. Tú no tendrás que preocuparte por comidas ni organizaciones, y ellos disfrutarán a su aire sin darte la lata. ¿Qué te parece?» (Giménez Bartlett, 2015: 186).

Pero no todas las mujeres pueden decidir sobre su maternidad. En Serpientes en el paraíso (2003) vemos cómo las empleadas del hogar, todas ellas extranjeras, tienen que dejar a sus familiar para cuidar de las familias de otras personas. La conversación hace sentir mal a Petra porque le hace ver las diferentes entre sus privilegios del primer mundo y la realidad de su interlocutora.

— ¿Tú estás casada?

—Sí. Mi marido quedó en Ecuador y mi hijo también.

Sacó del bolsillo de la bata una foto que debía de llevar siempre consigo y me la mostró con ademán orgulloso. Era un indiecito moreno, de ojos redondos y curiosos que no aparentaba mucha más edad que la niña de los Puig.

${ }_{i}$ Es muy guapo!

Curioso mundo, complicado. Aquella mujer tenía su propio hijo a miles de kilómetros y cuidaba de una niña que no era suya. 
- Mando dinero todos los meses y cuando pasen dos años a lo mejor ya puedo ir para allá (Giménez Bartlett, 2003 [2013]: 957).

La situación de estas mujeres es dramática. Dejar a sus familias y en especial a sus hijas e hijos provoca disfunciones en sus relaciones con éstas y estos que, si la separación es muy larga, pueden llegar a manifestar sentimientos de desapego y abandono. Mientras, se convierten en los referentes afectivos de las niñas y niños que cuidan. Por otro lado, en el fragmento que reproducimos la mujer habla de su hijo y su marido, pero en la mayoría de los casos son otras mujeres las que se ocupan del cuidado de estas niñas y niños en origen, siendo las mujeres de la familia (abuelas, tías, hermanas, etc,) o mujeres a las que se contrata para ello las que realizan esta tarea (Parella Rubio, 2003). Así se consolida la reproducción como una función de las mujeres y se ahonada en la discriminación.

Volviendo a la saga de la inspectora Delicado, y observando más de cerca la vida privada de Petra, veremos que Giménez Bartlett está preparando el camino a la maternidad mucho antes de que aparezca el personaje de Marcos con toda su prole. Desde la primera entrega Petra reconoce que, del mismo modo, que en su primer matrimonio adoptó una actitud de sumisión y de desprotección frente a Hugo, en su segundo matrimonio basculó al lado contrario y es ella la que adopta un rol maternal con Pepe (su segundo esposo) al que le cuesta quitarse en encima después de la ruptura (Pepe dejará de estar en la vida de Petra cuando se case con una periodista, también mayor que él).

Por otro lado, en Días de perros (1997), vemos que la solitaria Petra tiene en Espanto, el perro testigo del asesinato, un compañero de piso al que cuida con cariño, a pesar de que Garzón le echa en cara que sobreestima al animal, «tampoco es Rintitín» (Giménez Bartlett, 1997 [2013]: 264), la inspectora considera que los ayudará en la investigación porque es muy inteligente e iba con Lucena, su dueño, a todas partes. Petra se une afectivamente, por primera vez, a otro ser vivo, más tarde sucederá con Marina, la que será su futura hijastra, cuando la conoce. De hecho, Delicado reflexiona: «Sin embargo, durante aquellos meses detectivescamente estériles Garzón había encontrado el amor por partida doble, yo había ligado con un veterinario y entrado en el club de los propietarios de perros. 
¿Qué más podía pedirse? Funcionábamos como una gran familia» (Giménez Bartlett, 1997 [2013]: 371).

Castro prefiere colocar a sus personajes en la posición de hijas con madres difíciles de tratar. Clara perdió a su madre, joven, a causa de un cáncer, pero para compensar está el personaje de su suegra. Una mujer de la clase alta de Madrid que cree que su hijo, Ramón, ha hecho un «mal matrimonio» y que su nuera no lo trata como debería. Clara es subinspectora de policía y no un ama de casa que está pendiente de las necesidades de su marido.

[...] entró en el ascensor refunfuñando y pensando qué mierda de día, y eso que acababa de empezar y ya se había meado la gata fuera del cajón y se escapaba la leche del cazo, toda desparramada y quemada en el fogón, y ya imaginaba después a Ramón que a ver para qué te regaló mi madre un microondas que le costó un güevo en El Corte Inglés, que menos mal que llevaba la Visa Platino, que dice que fue verlo y pensar mira tú lo bien que le viene a la paleta esta que está con mi hijo para que no se le salga la leche, que luego, como es tan liberada y tal, deja la cocina hecha un asco y le va a tocar fregar a él, que es tan sacrificado, angelito, y llega antes a casa y se lo come todo, y pobrecito mi niño (Castro, 2008 [2010]: 6-7).

La suegra de Clara es el ejemplo de madre abnegada y sacrificada, sin embargo su hijo la considera un verdadero incordio, no es comprensivo con la situación de una mujer a la que han enseñado que las mujeres deben ser cuidadoras, deben estar pendientes de su familia y, de repente, se da cuenta de que no hay nadie a quien cuidar. Ramón, durante una pequeña discusión con Clara le advierte: «Porque, esto te lo aviso ya, por nada del mundo me voy yo a casa de mi madre, que es una pesada que no para de tocarme los huevos. De modo que, tal y como está el panorama, mejor empezamos a hablarnos ahora mismo o nos repartimos los gananciales» (Castro, 2008 [2010]: 30).

Mientras Clara Deza se debate entre las diferentes posibilidades y lo que dice su reloj biológico, Ramón y ella tienen una gata que no siempre la quiere. «Hasta la gata me rehúye» (Castro, 2008 [2010]: 14), lo que la hace dudar de sí misma en 
muchas ocasiones. Ya que, a pesar de ser ella la que le da de comer, cuando se acuerda, la gata prefiere a su amo, es la gata de Ramón.

Algunos de los crímenes que investigan Petra y Clara tienen un denominador común, pues las figuras maternas y paternas con frecuencia presentan la vertiente de madre/padre monstruo. Barbara Creed (1993 [2012]) desarrolla la idea de lo femenino-monstruoso ahondando en el concepto de madre-monstruo como una manifestación del cine de terror, una representación que, en cierto modo, se ve materializada en el personaje de Teresa Sinde, en el rol de hija de esa madremonstruo. Desde un punto de vista psicoanalítico, se trata de una mujer castradora que provoca miedo en los hombres y cuya fantasía sólo tiene sentido dentro de una sociedad patriarcal. En este caso, la hija unida al padre será la que sufra el terror al monstruo, un terror que supera con pequeñas rebeldías. Ofelia, la madre de Teresa, ya hemos comentado que es la mujer perfecta, siempre en su sitio. No se permite, ni permite a las personas que la rodean ningún error. Teresa Sinde, niña, tiene en su padre a un cómplice de juegos, a un espíritu libre, diametralmente opuesto a su madre. Un hombre extravagante que inventa un juego para su hija en el que se inventan historias sobre las personas que ven (Castro, 2010: 111). Un hombre al que su esposa «castra» metafóricamente afeándole sus conductas hasta que es ingresado en un centro psiquiátrico cuando su comportamiento errático es insoportable para su mujer. El padre de Teresa no se recupera nunca y acaba suicidándose. En ese momento, la niña ocupa la posición de su padre en el perturbador ecosistema de Ofelia.

Después de la muerte de su madre, Teresa Sinde, adulta, se venga del dominio que Ofelia ejerció sobre ella. Una de estas pequeñas revanchas se materializa en Je Reste, la mansión que su madre convirtió en escuela de cocina de prestigio y que Teresa transformó en su domicilio. De niña, la «incontenible hipocondría» de su madre le impidió tener animales y el jardín siempre estaba perfectamente cuidado. La cocinera se siente unida al jardín y «empatiza» con la fauna y la flora que lo habitan (árboles de todo tipo como robles, gatos, etc.). Sinde confiesa: «Antes de cerrar me giro $\mathrm{y}$, en el umbral, reto con mi rebeldía acostumbrada a los árboles más cercanos aunque, he de reconocerlo, mezclada 
esta tarde con un poco de cansancio» (Castro, 2010: 127). Una vez dentro de la casa, continúa:

Avanzo por la casa a oscuras y me guío a tientas hasta la cocina. Cada vez que entro pretendo olvidar a quién perteneció y ahora me concentro en preparar algo [...] La jornada en el restaurante ha sido realmente larga y me gustaría sentirme diferente, nueva, otra, sin tener que recordar constantemente la hija de quién soy [Ofelia], que le debo tanto que por su causa me reconozco como la que leéis ahora, que puedo librarme de su recuerdo (Castro, 2010: 127).

Si bien en la mayoría de los casos sus venganzas están destinadas a acabar con el legado de su madre, al final de la historia, nos enteramos del mayor acto de revancha que se cobra Teresa con su madre, cuando huye con Germán y piensa:

A fin de cuentas no tengo nada que perder: Estrella y Tomás lo entenderán y se encargarán de todo en mi ausencia, recogerán la libreta roja que acabo de abandonar sobre la mesa de la cocina, regarán los árboles y las plantas con cuidado de esquivar las carnívoras y estoy segura de que tarde o temprano descubrirán el mejor modo de alimentar a los gatos que pululan por el jardín. Incluso duda que se sorprendan cuando al abrir las ventanas y airear mi casa, den en el piso más alto, en el torreón, con un cuarto clausurado, vetado, sin llave en el ojo de la cerradura oxidada que hace tanto que no se abre. Por mucho que intenten escuchar, aunque lleguen a pegar la oreja en la puerta, no oirán los débiles golpes, los frágiles aullidos, los imperceptibles rasguños que con sus dedos de hueso insiste en repetir en la madera la incorpórea Ofelia, arañando una y otra vez, sin posibilidad alguna de huida, derrotada, castigada en esa tumba sin bendecir, negrada a la posibilidad que tanto ansiaba de purgar sus penas y sus pecados durmiendo en tierra consagrada (Castro, 2010: 440).

Teresa había desenterrado el cuerpo de su madre para poder consumar esta venganza. La madre monstruo por excelencia aparece en Mantis (2010). Teresa Sinde no quiere que su hijo sufra como ella sufrió a causa de la falta de padre, al lado de una madre abusiva, madre monstruo. Así que cuando Agustín le dice que no la desea como antes y que tiene que separarse, Teresa toma la iniciativa.

Así pues, decidí en un instante que no me importaba si Agustín era infeliz y me daba igual si tenía a otra que le esperaba golosa. Lo que debía hacer ahora era 
permanecer a mi lado no por mí, que tampoco le amaba e incluso desde hacía unos minutos le despreciaba, sino por nuestro futuro hijo. No estaba dispuesta a que creciera partido por la mitad en una casa desestructurada que sembrara su miedo a crecer. Precisamente porque sabía lo que se sentía en un mundo como aquél ése no era el futuro que deseaba para mi bebé (Castro, 2010: 358).

Pero al final no hay embarazo sino un ingreso en un centro psiquiátrico. Nadie la cree y menos su madre que, como de costumbre, la maltrata despiadadamente. Cuando le pide ayuda para ella y el futuro posible bebé, la madre le dice que todo el mundo piensa que está loca y que acabará como su padre. Teresa intenta defenderse, pero sólo consigue que su madre continúe con su ataque: «¿Qué tonterías estás diciendo?, ¿ves cómo también estás loca? Eres igual de pusilánime, primero te inventas un embarazo y al final acabarás en el psiquiátrico con él» (Castro, 2010: 361).

Una madre monstruo que vamos componiendo con los recuerdos de Teresa. Durante su infancia sufrió la más absoluta de las indiferencias por parte de su madre. Una mujer de clase alta que enviuda y debe ponerse a trabajar para mantener su tren de vida. Lo consigue convirtiéndose en su propia imagen de marca. Ofelia Valverde «perfecta dama y su vivienda lo era también. El marco ideal para una digna viuda de noble cuna y modales exquisitos que supo sacar partido de una de sus más encomiables cualidades como esposa y ama de casa y levantar un boyante negocio de la nada» (Castro, 2010: 28). A Ofelia le gustaba «reinterpretar los guisos adaptándolos a sus nuevos artilugios que las compañías de electrodomésticos no cesaban de inventar» (Castro, 2010: 30). Teresa, adulta, lleva a cabo sus pequeñas venganzas contra su progenitora. También reputada cocinera, sus recetas son lo contrario a las de su madre: «Yo pienso en términos de deseo, de hambre, de anhelo, porque es lo único que me mueve ahora» (Castro, 2010: 47). «Yo sólo pretendo cocinar y experimentar, jugar con los ingredientes...» (Castro, 2010: 67).

El recuerdo que Teresa tiene de su madre, el que nos transmite, es el de una mujer dura, falta de empatía, y explotadora. Al trasladarse al edificio que sería su casa y centro de trabajo, Ofelia llevó a Malvina para que cuidara de Teresa, pero la mujer era mayor y no podía seguir su ritmo. Ofelia tomó la decisión de que Malvina 
trabajase en la escuela de cocina y llevó del pueblo a Cecilia, la hija que tuvo de soltera, para que cuidara de la pequeña. A nadie le importaba que Ofelia explotara a la joven niñera.

Teresa cuenta, para ilustrar su infancia, que tenía una muñeca Nancy y para Reyes Magos quería los complementos de la muñeca, como el resto de compañeras. Sin embargo, su madre ignora sus deseos y le regala lo que más le gusta a ella. «[...] para mi desconsuelo, sólo encontraba bajo el árbol una caja con un vestido para mí de precio desorbitado y objetos tan absurdos como una pulsera de oro o unos pendientes de perlas. Todo del gusto de mi madre pero nada adecuado para una niña» (Castro, 2010: 86).

Cecilia, por su parte, la conoce mejor que su propia madre y se rebela como una especie de Mary Poppins, una personalidad maternal que cuida de la niña con cariño. Para remediar los desastrosos regalos de Navidad se ofrece a ser ella quien los adquiera, para lo que Ofelia le da una cantidad irrisoria de dinero. Teresa tiene los vestidos para la Nancy, «sólo que a cada conjunto le faltaba su correspondiente par de zapatos» (Castro, 2010: 87).

Cuando Teresa tenía 13 años, a Cecilia le diagnosticaron una leucemia y falleció en unos meses. «Ofelia poseída por ese sentido práctico suyo tan ingrato como cruel: "Ahora que su dormitorio ha quedado vacío vamos a instalar un cuarto de planchar"» (Castro, 2010: 87). Malvina y Teresa recogieron las cosas de Cecilia para que Ofelia no las tirara a la basura y, entonces, descubrió que Cecilia hacía los vestidos para la Nancy y por eso los conjuntos no llevaban zapatos. Este episodio explica el ansia irrefrenable de Teresa por los zapatos. «Así me inoculó este veneno extraño, esta congoja que me embarga al descubrir en un escaparate un par espectacular que no poseo y que comienza a dominarme en cuanto aspiro el olor del cuero y acaricio su tacto suave y sucumbo al deseo y me los pruebo. Es un apetito que nunca se acaba, que me domina y me atrapa» (Castro, 2010: 88).

Junto al desmantelamiento de la escuela de cocina y al decantarse por la cocina creativa, Teresa realiza otras pequeñas venganzas como desinteresarse de la publicación del recetario de su madre: «Me da igual quien publique las recetas 
de mi madre» (Castro, 2010: 98). Lo importante es destruir el legado de Ofelia Valderrama.

La conclusión de la historia que plantea Mercedes Castro para esta trama recuerda, en cierto modo, a la película Psicosis (Alfred Hitchcock, 1960). Teresa desenterró a su madre y la encerró en la torre del palacete para que pudiera ver todo lo que estaba haciendo, su pequeña venganza, un gesto que se puede interpretar como liberador o como patológico, ya que en definitiva no puede deshacerse de la influencia de esa madre monstruo.

¿No se puede identificar esta situación con la misoginia? ¿Qué gana una autora con un personaje que podemos calificar de negativo? Mantis (2010), como señala la propia autora, se trata de un juego de ironías sobre los estereotipos tanto femenino como masculino, pretende dar un paso más allá de la guerra de los sexos porque «en esta sociedad todos estamos jodidos y tanto las mujeres como los hombres tienen sus problemas para asumir su rol social, atemorizados por lo políticamente correcto, que nos puede a todos». Además, puntualiza que no se burla tanto de los estereotipos de género como del «consejero delegado, del librero cultureta o de la mujer fatal, poco fatal». Es decir, su crítica «irónica se centra en los estereotipos sociales, a las clases, oficios y profesiones». Castro señala que en la actualidad se juzga a las personas sin tener en cuenta la responsabilidad que la sociedad pueda tener en su comportamiento y que la intención en la novela es poner el acento sobre el hecho de que las personas con responsabilidades (como el consejero delegado) siempre acaban eludiendo esta responsabilidad porque culpan a terceros de sus desmanes o sus meteduras de pata (Castro en Europa Press, 16 de abril de 2010). La escritora confiesa que la novela se convierte, con su sátira, «en la crónica del devenir de muchos monstruos modernos. En ella, o al menos eso he intentado, hay muchos más lobos de lo que parece a simple vista» (Castro en Filadón, 13 de junio de 2010: en línea).

Pero la crítica más intensa se dirige al «mundo de las apariencias» en el que se mueve Teresa, y donde su belleza influye directamente en sus relaciones. Con este personaje, una femme fatale, actualiza este arquetipo literario y lo trae a nuestros días para reseñar que «es mala porque el mundo la hizo así», «falta de amor e incomprensión [de su tiempo]», en realidad está buscando su identidad. Y 
consigue que consideremos que sus actos y sentimientos están influidos por la presión social y el mundo que les rodea.

Así pues, la posible misoginia se descarta porque la autora se posiciona dentro del marco de la crítica social y considera que «la ambigüedad, la mezcla de fantasía y realidad, no son más que componentes del artificio literario, del misterio final en torno al cual gira la trama y la intriga de la novela, poblada adrede de dobles sentidos y, espero, dobles lecturas» (Castro en Filadón, 13 de junio de 2010: en línea). Y, sobre todo, porque Mercedes Castro juega con la lectora y lector mediante referentes culturales actuales, mezcla de géneros, etc. a lo largo de toda la novela.

Giménez Bartlett tampoco es ajena a este tipo de madre y en la primera entrega (Ritos de Muerte, 1996) de Petra Delicado, la instigadora de las violaciones que investiga la pareja de policías es una madre represiva obsesionada por la decencia. Nido vacío (2007) gira en torno a una madre abusadora que vende a su hija para sacar dinero. Es cierto que hay miseria, pero no cabe duda que la perversidad de esa madre desencadena situaciones mortales. En Nadie quiere saber (2013) Delicado y Garzón se enfrentan a una paternidad enferma, reforzada por una maternidad ausente. Mientras el padre monstruo de Adolfo Siguán abusa de sus hijas, la madre ha sido anulada por su marido y no las defiende. En su declaración una de las hijas señala:

A mi madre, una mujer insignificante y dócil, la machacó a conciencia. La trataba como se trata, o mejor dicho como se trataba en el pasado remoto, a una criada. Creo que se casó con ella sólo porque era la norma y para que le diera hijos que pudieran heredar la fábrica. Mi madre tuvo la desdicha de que no naciera ningún varón, y a partir de ahí el desprecio de mi padre por ella se hizo aún más patente. En general tenía una opinión pobre y anticuada sobre las mujeres (Giménez Bartlett, 2013: 69).

En el resto de entregas hay diferentes perfiles de madres más o menos protectoras, más o menos ausentes, sobre las que Petra presenta un juicio. 


\subsubsection{Representación de las relaciones de los personajes femeninos en Alicia Giménez Bartlett y Mercedes Castro}

Algunos feminismos contemporáneos señalan la sororidad como una de las formas de relación entre las mujeres:

Es una experiencia de las mujeres que conduce a la búsqueda de relaciones positivas y alianza existencial y política, cuerpo a cuerpo, subjetividad a subjetividad con otras mujeres, para contribuir con acciones específicas a la eliminación social de todas las formas de opresión y al apoyo mutuo para lograr el poderío genérico de todas y al empoderamiento vital de cada mujer (Lagarde, 1993 [2006]: 3-4).

Dolores Juliano (1998: 82) realiza, también, un análisis de las relaciones entre las mujeres, para ello, estudia la importancia de las «redes femeninas familiares», laborales, entretenimiento y religiosas. Estas relaciones no suponían elementos censurables para el conjunto social, ya que solía reforzar la «autorreproducción de la estructura social» y no cuestionaba la realidad social en la que es constituían dando a las mujeres del grupo la posibilidad de desarrollar su proyectos. Sin embargo, Juliano (1998: 82) observa que esta función indirecta colisiona con el papel asignado a las mujeres, a tenor de la «incomodidad intelectual que ha producido el reconocimiento mismo de su existencia».

Las sociedades patriarcales han utilizado tradicionalmente una estrategia de división para «debilitar la organización y resistencia de los sectores subordinados», en este caso, de las mujeres. La estrategia se sustentaba en dos vertientes: fraccionar el colectivo (por ejemplo patrilocalidad) ${ }^{141}$ y limitarla al ámbito doméstico. De esta manera, la relación entre miembros del «colectivo mujer» es mínima. Además, esto se refuerza construyendo un entramado ideológico que sustenta la idea de que las mujeres no pueden mantener relaciones entre ellas (la idea popular de que las mujeres son peores con las mujeres que los hombres, o que las mujeres se critican entre ellas de manera despiadada, etc.).

\footnotetext{
${ }^{141}$ En antropología hace referencia al hecho de que un matrimonio establece su residencia, después de la boda, en la casa paterna del novio (Kottak, 1971 [1991]).
} 
[...] esa imagen según la cual sería mayor la capacidad de solidaridad de género entre hombres que entre mujeres, y la idea que las mujeres compiten entre ellas y se solidarizan con los hombres, implica una impotente distorsión del funcionamiento real de las estructuras sociales (Juliano: 1998, 83).

Esta afirmación que se cimenta en el hecho de que los hombres tienen amigos con los que comparten tiempo libre, trabajo, etc. mientras que las mujeres no comparten estas amistades se produce por la organización social que, como hemos señalado, evita que las mujeres puedan encontrarse en contextos sociales fuera del entorno doméstico. Sin olvidar que es difícil entablar amistades, «establecer relaciones de solidaridad», si el tiempo está ocupado en los cuidados de la familia y el hogar. Ahora bien, Juliano (1998: 83) concluye que «si definimos la amistad como la capacidad de disponer del tiempo propio a servicio de los demás, es claro que la definición se adecúa más a las relaciones entre mujeres que a las que se producen entre hombres».

La diferencia de los feminismos que estaban en boga en el momento en que las autoras comienzan a escribir se ve reflejada en las relaciones que las protagonistas tienen con otras mujeres, aunque las autoras afirmen que sus personajes no son feministas. Una vez más Petra Delicado intenta alejarse de otras mujeres, tanto fuera como dentro del trabajo. «Yo era policía, no psiquiatra, ni directora de una $\mathrm{ONG}$, ni una mujer solidaria con mis compañeras de sexo» (Giménez Bartlett, 2000: 1037). Huye de las relaciones $\mathrm{y}$, sobre todo, de la intimidad. De hecho, considera que puede vivir sola con alguna relación esporádica con algún hombre que conozca por motivos profesionales. Esto, en cierto modo, se rompe cuando se casa con Marcos y debe enfrentarse con la conciliación de la «maternidad por poderes» y su trabajo. Además, las jóvenes agentes con las que trabaja la admiran e intentan constantemente acercamientos que, aunque rechace en un primer momento, influyen en su conducta, protectora hacia ellas y de mentora en todo momento.

Clara Deza y Petra Delicado son conscientes del mundo masculino y masculinizado en el que trabajan. De hecho, Clara siente que la camaradería masculina la arrolla y tiene que aceptar aspectos con los que no se siente cómoda en el ámbito laboral. La subinspectora considera que no la tienen en consideración. 
Y todos, pero todos, con sólo una mirada se ponen de acuerdo y comienzan a evaluar la escena tras echar a los vecinos curiosos, aquí no hay nada que ver, esperen fuera, por favor, ya les tomaremos más adelante los datos para la declaración, y no se cortan un pelo, ni uno, y todos excepto París -ese cobarde que se hace el sordo con el rabo entre las piernas y no se decide a tomar posición entre ellos y yo (Castro, 2008 [2010]: 106).

Además, cuando llega al escenario del crimen no se callan o cambian su forma de hablar sobre el cadáver porque consideran que a las cosas se les llaman por su nombre, que para los compañeros de Clara son: teta en lugar de pechos, coño en lugar de vagina, puta, en vez de prostituta, y estas últimas son vistas como un objeto para usar. Clara Deza no es políticamente correcta, pero sí preferiría que hubiera respeto.

No, no se callan porque no les da la gana, y que me joda si me molesta, y que a las cosas se les llama por su nombre porque sí, porque así son y así las dicen ellos y que no venga con remilgos ni con aspavientos ni con amenazas de degüello, porque son hombres, qué cojones. Y si no me gusta ya me puedo ir yendo, porque las tetas se llaman tetas, las putas, putas son y los coños negros agujeros. Y ni senos ni prostitutas ni vaginas; a cada cosa su nombre y con un par (Castro, 2008 [2010]: 106).

Esta camaradería entre mujeres, lleva a Clara a enfrentarse con el mundo de hombres en el que trabaja.

-Y yo me congratulo de que sus opiniones sean unánimes, pero lo que me gustaría es que me dieran una orden precisa al respecto -interviene Clara bastante quemada después de oír cómo califican a su pobre amiga Laura de poco profesional, incluso de fresca, hay que ver qué jeta, y me refiero a la de ellos, por supuesto, que carecen por completo de la objetividad necesaria para verse a sí mismos como yo los veo ahora: endiosados, chulos, tan convencidos de su valía, de sus dotes de mando para decirnos cómo actuar, para montar una operación en la que no sabrían qué hacer si tuvieran que ser ellos los que se pusieran delante de Virtudes dispuestos a ser contemplados, evaluados y vejados como en una feria de ganado (Castro, 2008 [2010]: 287).

Petra comienza rodeada de compañeros hasta la llegada de las nuevas agentes, Yolanda y Sonia. La relación que entabla con ellas es de una especie de 
mentora, a pesar de que le abruma. Siente especial inclinación por Yolanda, que es más «espabilada» y que a su vez siente una gran admiración por la inspectora. Por esta relación llega a convertirse en una especie de protectora de las chicas.

Beatriz, la mujer de Garzón, en la fiesta de cumpleaños de la joven policía le hace ver: «-Yolanda te admira mucho. Dice que le gustaría llegar a ser una policía como tú y hacer las cosas como tú las haces» (Giménez Bartlett, 2007 [2013]: 1404). La inspectora reconoce que la agente siempre está dispuesta para el trabajo, pero esta devoción suponía una gran responsabilidad.

Nunca se enfadaba cuando yo la trataba con dureza; lo cual me hacía arrepentirme indefectiblemente de haberle hablado mal. Sin embargo, en esta ocasión me reafirmé. No podía arriesgarme a que Yolanda me viera como una figura materna. Me admiraba, me obedecía ciegamente... No, ser referente de alguien comporta demasiada responsabilidad, y eso me agobiaba de antemano (Giménez Bartlett, 2007 [2013]:1410).

Teresa Sinde, también, tiene una relación de hermandad con su secretaria, amiga y compañera, una relación casi maternal, una madre cuidadora que no había tenido antes. Es cierto que, en este caso, media una compensación económica porque trabaja para ella, pero Teresa reconoce que es mucho más:

Porque Estrella me recompuso cuando estaba rota. Porque Estrella, en mi oscuridad, es la luz que me guía por el mundo de los negocios. Porque Estrella me levantó después de tantos meses descosida y me forzó a pensar, a maquinar, a alzar la cabeza, también a ser en cierto modo una arpía. Hay personas, como yo, que se dejan ir con los embastes de la vida, que se desguarnecen y descomponen tras una fuente acometida, que permiten que los arrastre la corriente. Hay almas cándidas, ingenuas, desprevenidas, que necesitan de alguien que les cargue las pilas. A mí me las pone, y bien, Estrella. Por eso habla de «nuestro» negocio. Porque éste, y probablemente también yo, no existiríamos sin ella (Castro, 2010: 47).

El sentimiento de sororidad, de complicidad por el hecho de ser mujer en un mundo hostil, no se da únicamente entre personas conocidas. Clara conoce a Remedios, la nueva novia de Carlos París, su ex, cuando va a buscarlo a comisaría. La joven inocente le cuenta que no sabe si ha hecho bien, pero que las compañeras 
le han convencido para que fuera a buscar a su novio, en quien no ve ningún defecto. «-Bueno, si me indicas de quién se trata a lo mejor puedo decirte si se ha marchado ya o no -se ofrece en un acto inesperado de solidaridad femenina, enternecida tal vez por la mirada perdida de esa chavala tan expuesta, indefensa, que pudo haber sido ella hace años» (Castro, 2008 [2010]: 97).

Éste es un sentimiento que Petra no puede ocultar tampoco cuando se encuentra con algunas testigos en los casos, pero que no le llevan nunca a un «acto inesperado de solidaridad femenina», la coraza que ya hemos descrito que se pone hace que sea más distante. Pero, ¿qué atractivo puede tener para la lectora una mujer que parece no empatizar con las compañeras y las testigos? Precisamente esa falta de empatía y de apego que acaba convirtiéndola en el modelo a seguir por parte de las jóvenes policías, mientras ella sigue negando su inclinación a proteger a las mujeres. Al entrevistar a una de las testigos por la muerte de Ernesto Valdés, la joven está preocupada por los celos de un marido que ha conseguido una esposa trofeo. Cuando Petra ve cómo la trata su marido se le quiebra, momentáneamente, esa coraza y dice:

— ¿Ve, Fermín, ve por qué no soy feminista? Si fuera feminista saldría a la calle y le daría una somanta al tipo ese. Y a ella también por pensar que el matrimonio, sea con quien sea, es su única solución. Y a Valdés volvería a matarlo por lo que hizo. Tampoco me olvidaría de darle unas leches al imbécil de financiero que quiso comprarla como una oveja. Para acabar les pondría una bomba a todos los que ven el programa de Valdés y a los que compran las revistas de cotilleo (Giménez Bartlett, 2000 [2013]: 776).

Como suele pasar en este tipo de conversaciones, Fermín tranquiliza a la inspectora con una chanza: «-Vale, vale, inspectora. Enrólese usted en el Ejército de Salvación Feminista y cuando me toque a mí el paredón, recuerde que éramos amigos» (Giménez Bartlett, 2000 [2013]: 777). Para acabar riendo, lo que textualmente le sirve a la autora para incluir a un público más amplio, como ella misma reconoce sobre el posicionamiento ideológico que adopta a la hora de escribir y que hemos visto en el capítulo anterior. 


\subsubsection{Representación de la violencia de género: de la agresión física a los micromachismos}

En España, el asesinato de Ana Orantes (1997) a manos de su exmarido supuso un punto de inflexión en la forma en que la sociedad veía la violencia dentro de la pareja ${ }^{142}$. Sin embargo, no sería hasta 2004 cuando se publicó la Ley Orgánica 1/2004, de 28 de diciembre, de Medidas de Protección Integral contra la Violencia de Género con la que se pretendía reducir, si no eliminar, las situaciones de violencia que se ejercían sobre las mujeres. Doce años más tarde, la violencia de género sigue siendo una lacra y la mayoría de los micromachismos o machismos 2.0 están más arraigados si cabe. Luis Bonino (2004), psicoterapeuta y psiquiatra que trabaja desde hace cuarenta años en temas relacionados con la promoción de la igualdad entre mujeres y hombres, define los micromachismos como

[...] esos comportamientos que son obstáculos y también resistencias para la igualdad con las mujeres en lo cotidiano. Me refiero a los «pequeños» y cotidianos controles, imposiciones y abusos de poder de los varones en las relaciones de pareja. Comportamientos, que son especialmente invisibles y ocultos para las mujeres que los padecen (Bonino, 2004: en línea).

A pesar de que Bonino habla de las relaciones de pareja, por nuestra parte ampliamos el ámbito de influencia a la estructura de la sociedad en su conjunto. Así, compartimos la idea, también expuesta por este autor, de que

Muchos de estos comportamientos no suponen intencionalidad, mala voluntad ni planificación deliberada, sino que son dispositivos mentales y corporales incorporados y automatizados en el proceso de «hacerse hombres», como hábitos de funcionamiento frente a las mujeres. Otros en cambio sí son

\footnotetext{
${ }^{142}$ Ana Orantes contó la situación de violencia que había sufrido durante su matrimonio en un programa de Canal Sur Televisión. Orantes se había casado a los diecinueve años y estuvo casada durante cuarenta años con su maltratador. En la sentencia de divorcio se determinó que debía compartir la casa familiar, dividiendo su uso. Así que su asesino, su exmarido, no tuvo dificultad en acercarse a ella y quemarla viva trece días después de su aparición televisiva. Los motivos fueron que se sentía despechado y no «aceptaba la rebeldía de la que fuera su esposa» (Montalbán Huertas, 16 de diciembre de 2007: en línea).
} 
conscientes, pero de una y otra forma, los varones son expertos de su ejercicio por efecto de su socialización de género (Bonino, 2004: en línea).

Los encontramos en todas partes, y una de las principales fuentes de estos machismos de baja intensidad está en el lenguaje:

- ¿Ustedes saben lo que es un hijoputa? -inquirió el comisario Coronas como toda presentación del asunto.

Al tiempo que Garzón contestaba sin fisuras «Desde luego que sí», yo inicié una perorata de resultados inciertos.

-Hombre, pues no sé. En realidad es curioso que los mayores insultos dirigidos a los hombres acaben también cayendo sobre la cabeza de una mujer. Porque ya me dirá, comisario, si porque un tío sea malvado o cabrón hay que cargárselo también a su madre. (Giménez Bartlett, 2000 [2013]: 689).

Clara Deza vive una situación similar: «Aunque para qué buscarle las cosquillas, para qué darme por aludida con sus indirectas y tirarme piedras encima. Para qué ponerme a su altura. Tengo que callarme y hacerme la tonta, la buena, la mosquita muerta. Y no decir tacos, que no son femeninos» (Castro, 2008 [2010]: 15).

Durante mucho tiempo, afirma Giménez Bartlett, el lugar de las mujeres en la novela negra era el de víctima o el de femme fatale, por eso decidió crear a Petra Delicado. La escritora revela: «quería un personaje que fuera mujer y que tuviera protagonismo. Porque la mujer en la novela negra o es la víctima, que aparece muerta en la primera página, o es la ayudante de alguien» (Giménez Bartlett en Kingery, 2013: 15). Si bien esta afirmación puede ser cierta para parte de la novela negra anterior a Gimenez Bartlett, como hemos visto antes, con el tiempo y la concienciación social sobre el tema de la violencia machista está cambiando la representación que se hace de ella en estas novelas. Giménez Bartlett, desde su primer asesinato, muestra esta realidad al poner en el centro de su relato una serie de violaciones, por cuyas víctimas siente poca empatía. La inspectora intenta, en todo momento, distanciarse de las víctimas y ser profesional, sin embargo, el hecho de que sea mujer hace que cuestionen su buen hacer en la investigación. La madre 
de Juan, el principal sospechoso de las violaciones, acude a la televisión para quejarse por el modo en que se lleva la investigación. Garzón le explica lo que ha declarado: «Considera que una mujer no debería estar encargada de investigar una violación. [...]Porque pone demasiada emotividad, se deja llevar por los sentimientos de las víctimas, y debe encontrar un culpable como sea, aunque éste sea falso» (Giménez Bartlett, 1996 [2013]: 165). Petra, que viene de hablar con el padre de una víctima, rico y poco colaborador, estalla contra Garzón: «-¿[Usted creía] Que tenía mi profesionalidad empeñada en esto, mi sentido del ridículo, mi conciencia femenina? Pues no, Garzón, estoy hasta los cojones de todo este guiso en el que las víctimas se comportan como cabrones. Por mí el violador puede follarse a las once mil vírgenes, me da igual» (Giménez Bartlett, 1996 [2013]: 166).

La representación de la violencia de género es un interés que las escritoras han manifestado como un tema en sus relatos con asiduidad, algo que las diferencia de sus compañeros. Quizás el interés venga dado porque ven a otras mujeres sufrir estas violencias y ellas las sufren. Si pensamos en antecedentes, hemos mencionado que Pardo Bazán ya mostraba interés en sus escritos por la situación de las mujeres. Nieves Alberola (2012b) analiza la representación de la violencia en diferentes autoras y autores y señala que Susan Gaspell (1876-1948), a través de sus personajes femeninos, también buscaba la libertad de las mujeres y el cambio legislativo.

No woman is free to enjoy human rights when violence against women is tolerated by her country, community, employer or family. Governments should be urged to take legal and other measures to prevent such violence when domestic battery is rarely investigated, and rape frequently goes unpunished (Alberola, 2012b: 207).

Comprobamos que Alicia Giménez Bartlett y Mercedes Castro también representan la violencia y ponen en boca de sus personajes la crítica a la situación existente, más de un siglo después.

Otros tipos de violencia también están presentes, como los casos donde se presentan mujeres en situación de vulnerabilidad, por ejemplo, por haber ejercido 
la prostitución ${ }^{143}$. En su penúltima entrega (Nadie quiere saber, 2013) vuelve a situar como eje central la violencia contra las mujeres, aunque no de manera tan explícita como en casos anteriores (Ritos de muerte, 1996; Nido vacío, 2007), ya que aunque se intuye no es hasta la resolución cuando se presenta la realidad de la violencia de un padre abusador (desde el principio sabemos que es un pederasta o cuanto menos consumidor de prostitución con trabajadoras sexuales jóvenes). Garzón le echa en cara a Petra que ella sólo ve ciertos machismos: «-Dijo que le daría una somanta al marido de Beatriz del Peral, y a ella también, y a un montón de gente más. ¡Hasta una bomba quería ponerles! Si eso no es juzgar [...] lo que pasa es que usted sólo es sensible al problema del machismo» (Giménez Bartlett, 2000 [2013]: 784).

En $Y$ punto (2008), se trata el maltrato en la relación chulo-prostitutas y, sobre todo, se marcan los micromachismos que sufre la protagonista de su entorno. Como cuando tiene que soportar los comentarios degradantes de los compañeros sobre la víctima, una prostituta joven.

Y hay días, como hoy, en que soy tan torpe que abro la inoportuna boca en vez de hacerme la loca y les fastidio especialmente la diversión y les corto el rollo más de lo habitual y me odian porque molesto más que nunca y les da por farfullar, por rebelarse, por rebotarse y agarrarse las pelotas ante mí con sus dos manos y se plantan y se ponen bordes y en esta especie de pulso que mantenemos, tan enormemente desigual, deciden de repente un día, ante una puta colgada como del árbol del ahorcado, que no se dejan avasallar (Castro, 2008 [2010]: 104).

Mercedes Castro realiza una incursión más profunda en la violencia de género, no sólo por la violencia que sufren las prostitutas asesinas y explotadas, sino porque en Mantis (2010) Teresa Sinde intenta frenar un incidente entre una pareja, evidenciando de manera explícita la existencia de este tipo de agresiones cotidianas, lo que se convierte en una denuncia.

\footnotetext{
${ }^{143}$ Un elemento curioso es que la casa de Petra en Poble Nou era un antiguo burdel. La inspectora reforma la casa y la transforma de un lugar de explotación de mujeres al hogar de una mujer independiente y empoderada. Esto lo vemos como una metáfora del cambio social que se está produciendo en la sociedad.
} 
La modelo se ve lívida y desencajada, el novio despechado, fornido y malhumorado, la agarra del brazo y la zarandea con fuerza, no con intención de hacerle daño, pero sí como un padre que reprende a un vástago travieso del que ya está francamente harto $y$, en cuanto al nuevo pretendiente, después de su momento de gloria, de la conquista insospechada que le tenía embobado, despierta al fin a la realidad, a la dureza de la ley del corazón y parece por un instante con el suyo roto y despejado.

-¡Zorra! -exclama a su lado el cazador desengañado-. ¿Pero qué te creías, que no te vi a través del cristal tonteando con ese memo de cocinero, enseñándole las piernas y riéndote al ver cómo babeaba? ¡No sé ni para qué me preocupo por ti! -y su mano cargada de rockero rebelde, traza una parábola siniestra destinada a golpearle donde más duele, donde más puede hacerle daño debido a su trabajo, en la mismísima cara.

-¡Ni la toques! -se interpone el encargado de la planta, que habrá perdido a la joven pero que no está dispuesto a que el otro siquiera la roce y que, tal vez por ese alelamiento del que todavía sigue preso, no consigue llegar a tiempo para frenar el tortazo, ese que al final recibiré yo, entrometida e intentando imprimir una autoridad que no poseo, como si mi cuerpo pequeño pudiera detener a estas dos moles, como si esta situación tuviera algún sentido (Castro, 2010: 122).

Teresa Sinde se transforma en una femme fatale justiciera que protege a otras mujeres y a sí misma de los «depredadores», convirtiéndose ella en el mayor depredador. En una reunión de negocios, el consejero delegado se porta con superioridad haciendo gestos como catar el vino para aparentar ser un aficionado experto. La acompañante se muestra nerviosa y le comenta que le gustan los zapatos que lleva. Teresa le comenta que es una «viciosa del calzado» a lo que acompañante responde que ella también. El consejero delegado comenta displicente: «Tampoco es tan raro -apostilla su superior hosco y evidenciando su hastío ante temas que considera en exclusiva femeninos-: Al fin y al cabo sois mujeres» (Castro, 2008 [2010]: 82). Teresa identifica la especie a la que pertenece este individuo, un maleducado que piensa que por tener una formación cara es mejor que el resto del mundo. Sin embargo, es un «repulsivo que no se da cuenta de lo maleducado que resulta [...] un individuo con una torpeza social descomunal 
que no puede soportar el peso de mis ojos cuando habla, y menos descifrar sus oscuros significados» (Castro, 2008[2010]: 83). Ésta será una de las víctimas de Teresa Sinde como justiciera femme fatale.

En este sentido, ¿qué tiene de atractivo este personaje para la construcción de una identidad femenina distinta a la definida por el patriarcado? Insistíamos anteriormente, cuando situábamos a la femme fatale en el contexto de la novela negra, que era un personaje «peligroso» porque se saltaba las reglas de la sociedad patriarcal y adoptaba una postura activa. Así pues, si bien desde un aspecto moral se puede censurar la conducta criminal de Teresa, contextualizada dentro del ámbito de la literatura de género negro y con la intención de Castro, nos muestra una mujer que se empodera para acabar tomando las riendas de su destino. En este sentido, resulta interesante que otras ficciones de novela negra también usen para representar el empoderamiento de las mujeres a asesinas. Como, por ejemplo, Juan Carrá (2016), que utiliza a una asesina a sueldo (envenenadora con cianuro) cuando quiere plantear el tema del empoderamiento en su novela negra. Al igual que Castro con este personaje quiebra el sistema clásico de bien y mal. De este modo, podemos observar que el empoderamiento de los personajes femeninos en la novela negra, por su carácter de crítica social, se produce tanto si son las detectives como si son las asesinas, porque la intencionalidad de la autora o autor es fundamental para este fin como elemento imprescindible para una comprensión lectora plena y satisfactoria. Es decir, en este caso, Castro dibuja a esta mujer fatal vengativa con connotaciones positivas para la lectora y lector, pero esto no tiene por qué ser siempre así, ya que como señala Elena Losada Soler (2015: 10-11):

Las autoras de narrativa criminal no constituyen un bloque homogéneo, no todas escriben desde la conciencia feminista, no usan la misma matriz literaria, no se sitúan en la misma perspectiva social, y tampoco los resultados obtenidos alcanzan el mismo nivel literario, pero entre todas crean un tejido de textura diversa que contribuye a la visibilización de la escritura femenina.

Una de las agresiones más extremas contra las mujeres son las violaciones porque suponen la afirmación de que su cuerpo no les pertenece. Susan Brownmiller (1975 [2013]: ebook) revisa diferentes conceptos de violación: 
violaciones rituales, la evolución legal del concepto, etc., para concluir que: «It seems eminently sensible to hypothesize that man's violent capture and rape of the female led first to the establishment of a rudimentary mate-protectorate and then sometime later to the full-blown male solidification of power, the patriarchy». De esta manera, las violaciones se convierten en la piedra angular del sostenimiento de las sociedades patriarcales y el control de las mujeres. El sometimiento del cuerpo de las mujeres (mediante la amenaza de la violación) justifica la aparición de «los conceptos de jerarquía, esclavitud y propiedad privada». De forma que, históricamente, la violación no era una cuestión de consentimiento o rechazo de la mujer sino un problema de propiedad del cuerpo de ella por parte de los hombres de la familia.

En épocas recientes, continuamos viendo cómo las violaciones son un arma de control social sobre las mujeres, que las empuja a seguir las normas establecidas sobre el lugar y la función que ocupan en la sociedad. La violación como mecanismo de control, comenta Lagarde (1993 [2006]: 261), «gira en torno al atemorizamiento y a la humillación de la víctima, recalca las diferencias jerárquicas entre los géneros y simboliza el sometimiento de la mujer al poder (físico) político de los hombres».

La saga de Petra Delicado empieza con un violador en serie (Ritos de muerte, 1996), «Catharine A. MacKinnon famously postulated in 1997 that "[i]n feminist analysis, a rape is not an isolated event or moral transgression or individual interchange gone wrong but an act of terrorism and torture within a systemic context of group subjection, like lynching"» (MacKinnon en Molinaro, 2016: 41). Mercedes Castro también presenta este tipo de agresiones en su ficción, y, como ocurre en el mundo real, en ocasiones se cuestiona que el hecho se haya producido.

Podría interpretarse simplemente como que le iba la marcha, lo que corroboran, por otra parte, las leves señales de violencia sexual. La señora era aficionada a los escarceos eróticos «intensos» y lo que sea que pasó fue después, me explica Dolores. Se han tomado muestras de Santi y de ella que confirman que estuvo con él. Hay semen en su vagina y piel bajo las uñas: a esto le llaman algunos forenses rancios «marcas de pasión» (Castro, 2008 [2010]: 359). 
Consideramos que al poner en duda la violación visibilizan una realidad social y la cuestionan. En las conversaciones de Petra y Garzón se observa que repudian estos actos y se posicionan a favor de la víctima, siempre desde una postura profesional, en parte, porque les sirve de «coraza» frente al sentimiento de dolor de las víctimas (Ritos de Muerte, 1996). Molinaro (2016) plantea que la representación en este relato de la violación tiene una doble función: legitimar la actuación policial y mostrar la jerarquía de género, añadimos, como elemento crítico con la desigualdad social.

In order to explain the enduring call for social correction, as embodied in the institution of the police, Giménez Bartlett subscribes to just such a view of gender violence, in part because crime fiction relies so extensively on the prevalence of social transgressions in order to validate the sustained commitment to governmentally sanctioned detection and correction and in part because the crime of rape, together with how fictional police detectives might make sense of this offense, corroborates the gender hierarchy by which men continue to control women's sexuality (Molinaro, 2016: 41).

Por otro lado, una de las formas de violencia de género más extendida en las sociedades matriarcales es la hipersexualización de la imagen femenina tanto en mujeres adultas como en niñas. A continuación, pasamos a analizar qué tipo de sexualidad presentan Petra Delicado, Clara Deza y Teresa Sinde.

Una de las violencias que el sistema ejerce sobre las mujeres con más virulencia son las exigencias relacionadas con la morfología del cuerpo. Así, nos parece significativo, como hemos señalado en el capítulo 3, que Petra no sea descrita físicamente de una manera minuciosa, a veces comenta alguna cuestión sobre la ropa que lleva puesta, pero no va más allá. En este sentido, Clara somete a sus personajes a una mayor presión sobre sus cuerpos. También en el capítulo 3 hemos mencionado la pelea que tiene Clara con Ramón, y como éste para insultarla menciona sus michelines. En el caso de Teresa esta necesidad de estar siempre preparada se entiende porque, aunque sea cocinera, en cierto modo vive de su imagen al tener un programa de televisión. Si no tuviera el físico adecuado no le producirían el espacio de cocina por muy innovadores que fueran sus platos. 
Giménez Bartlett hace referencia a este culto a la imagen o la necesidad de tener un cuerpo perfecto en Muertos de papel (2000), donde se sumerge en el falso mundo del corazón donde todo es apariencia. Hecho que hace que se cuestione su aspecto, aunque supera la inseguridad porque estar pendiente del aspecto es cansado.

\begin{abstract}
¿Por qué me preocupaba tanto en aquellos momentos la imagen que pudiera proyectar en las mentes ajenas? Habitualmente no suelo pensar demasiado en ese particular, acaba siendo aburrido, incluso enloquecedor. En el fondo todos somos una mezcla variable de la realidad y de cómo nos gustaría ser (Giménez Bartlett, 2000 [2013]: 686).
\end{abstract}

\title{
4.1.6. Representación de la sexualidad de las protagonistas en las novelas de Alicia Giménez Bartlett y Mercedes Castro
}

La representación de la identidad sexual es un tema controvertido. La mayoría de las sociedades plantean un sistema sexual binario, mujer/hombre, y la reflexión en torno a la sexualidad de los individuos se circunscribe a estas dos dimensiones, tanto si se habla de género como si se habla de sexo. Hemos hecho girar toda la investigación sobre un principio que establecía que existe un estereotipo de género, es decir, se caracteriza a las personas con unas habilidades y capacidades que dependen de su sexo biológico. Éste es un sistema que estableció la antropóloga Gayle Rubin (1975) en el ensayo El tráfico de mujeres. Notas sobre la «economía política del sexo», en que define los conceptos de sexo, género, y la relación entre ellos. Actualmente, estos conceptos se han quedado pequeños porque la evolución social ha dado visibilidad a identidades sexuales que no encajan en este sistema binario.

Sin embargo, autoras como Judith Butler (1990) complejizan el sistema señalando que el sistema es reduccionista y añadiendo que el sexo es tan performativo como el género, es decir, se construye más allá de una realidad biológica. La crítica de Butler a la teoría feminista radica en que necesita emplear un lenguaje (normativo) para expresarse y, por lo tanto, sólo se puede definir 
como elemento dentro del sistema, lo que en cierto modo deslegitimaría su definición. Entre otras cosas porque para Butler la creación de un sujeto femenino único resulta coercitiva y no le permite desarrollarse con plenitud e incorporar el concepto «mujeres», que incluye a feministas negras, lesbianas, etc. Y desde luego deja fuera del sistema a homosexuales, transexuales e intergénero, pues las combinaciones de sexo-género son numerosas. En este sentido, el sistema genera unas expectativas sobre el individuo que deja fuera a quienes no se ajustan a él. La norma de las sociedades patriarcales establece que el sexo es una categoría conformada por machos y hembras (biología); el género se refiere a hombres y mujeres (cultural); el rol de género hace referencia a la masculinidad y la feminidad (social); la orientación sexual es heterosexual, sea cual sea la categoría anterior a la que se adscriba; finalmente, las prácticas sexuales se ciñen a unos códigos heterosexuales. En este sistema quedan fuera muchas personas que están en los márgenes.

Sólo después del trabajo que los movimientos sociales han realizado, en algunas sociedades contemporáneas, se ha empezado a tener en consideración a estas personas. Algunos sujetos empiezan a ser reconocidos, como aquellas personas cuya orientación sexual, sea cual sea su sexo, género o rol, es diferente a la normativa: homosexuales, lesbianas, bisexuales. Pero todavía se excluye a personas que no se ajustan al sexo o a los géneros establecidos, intersexuales y transexuales quedan en tierra de nadie, y entre la aceptación y el rechazo aquellas cuyo rol de género es confuso: mujeres «masculinas», hombres «afeminados», entre otras posibles combinaciones. Meri Torras (2016), dictó el modulo «Representación, cultura, sexualidad», en el curso abierto en línea y masivo de la Universidad Autónoma de Barcelona, Representaciones culturales de las sexualidades, en el que presenta un cuadro sobre las expectativas sociales sobre los individuos en relación a su sexualidad que clarificaría estas sexualidades normalizadas y de la periferia: 


\begin{tabular}{|c|c|c|c|}
\hline & NORMA & & EXCLUSIÓN \\
\hline sexo & macho & hembra & intersex \\
\hline género & hombre & mujer & transexual \\
\hline rol de género & masculinidad & feminidad & $\begin{array}{l}\text { mujer } \\
\text { masculina } \\
\text { hombre } \\
\text { afeminado, etc. }\end{array}$ \\
\hline $\begin{array}{l}\text { orientación } \\
\text { sexual }\end{array}$ & $\begin{array}{l}\text { heterosexual } \\
\text { (deseo por el } \\
\text { sexo opuesto) }\end{array}$ & $\begin{array}{l}\text { heterosexual } \\
\text { (deseo por el } \\
\text { sexo opuesto) }\end{array}$ & $\begin{array}{l}\text { homosexualida } \\
\text { d } \\
\text { lesbianismo } \\
\text { bisexualidad }\end{array}$ \\
\hline $\begin{array}{l}\text { prácticas } \\
\text { sexuales }\end{array}$ & $\begin{array}{l}\text { código } \\
\text { heterosexual }\end{array}$ & $\begin{array}{l}\text { código } \\
\text { heterosexual }\end{array}$ & \\
\hline
\end{tabular}

Tabla. Expectativas sociales sobre la sexualidad de los individuos. Meri Torras (2016)

Los personajes de Giménez Bartlett (Petra Delicado) y Mercedes Castro (Clara Deza y Teresa Sinde) pertenecen a esta categoría confusa al tener profesiones tradicionalmente masculinas, lo que las obliga a generar mecanismos de adaptación que las protejan. Aunque tenemos que tener en cuenta que estamos hablando de personajes dentro de la novela negra, es decir, unos personajes que deben tener unas características sexuales concretas dentro del esquema de normalidad que planteamos más arriba (Tabla).

Hemos hablado anteriormente de Gay Flower, un personaje estereotipado que estaría fuera de la representación sexual de la norma, tanto en el aspecto de rol, como orientación y práctica sexual (recordemos que PGarcía le asigna una especial habilidad en lo que a moda se refiere, un lenguaje afectado, etc.). El escritor valenciano hace una sátira del detective de hard-boiled a través de este personaje. Marta Sanz también se decanta por un personaje homosexual y también por convertirlo en el detective protagonista, alejándolo así de la representación de víctimas y ese ambiente de secretismo y ocultamiento vergonzoso que ha sido más habitual en la literatura negra. Arturo Zarco, un detective cuarentón que ha descubierto su atracción por el «efebos» de adulto. Él mismo reconoce: «Como un refinadísimo Philo Vance. Al mismo tiempo, fuerte y viril. Guapo. No puedo evitar ser una persona pulcrina ni que me gusten los muchachos de baja estatura y 
complexión débil» (Sanz, 2010: 13). Un elemento que Sanz utiliza con profusión son las constantes referencias al género negro, tanto cinematográfico como literario: Philo Vance, nada más empezar la saga; el doctor Watson; los espejos rotos de la dama de Shanghai; Lana Turner; El espejo se rasgó de lado a lado, a la que califica de «la novela más siniestra de Mrs. Christie» (Sanz, 2010: 67), entre otras muchas. El profundo conocimiento del género negro hace que Sanz pueda mezclar con solvencia diferentes tipos de novela negra, algo que quedará patente en Zarco. Por ejemplo, el detective tiene «un compañero», Paula Quiñones, su exmujer, quien después del divorcio continúa en su vida a través del teléfono como «Socia», pero también una molesta voz que le lanza constantemente pullas en las conversaciones telefónicas que mantienen sobre cada caso.

Zarco conoce, durante la investigación del primer caso, a Olmo, «un elfo de ojos rasgados y violetas... Un muchacho de cuerpo menudísimo y moreno... Un elfo que huele a leche con vainilla y a lápices» (Sanz, 2010: 24). La diferencia de edad no nos muestra cuál de los dos tiene más experiencia en las relaciones, y se intercambian los papeles de maestro alumno. Lo cierto es que Olmo se configura como «la seductora femme fatal de una película de los cincuenta» (Sanz, 2010: 54) que manipula y engaña al detective. De hecho, en el segundo volumen de la saga, Arturo pone tierra de por medio al enterarse de que Olmo le ha sido infiel, con un hombre y una mujer. En este sentido, se transpone el modelo de protagonista heterosexual en muchas de las novelas negras (Gutiérrez, 2014).

Una de las características que Zarco comparte con sus compañeros detectives es, precisamente, la individualidad, así que se resiste a que lo etiqueten dentro de cualquier categoría. Arturo declara: «porque a mí me sigue irritando que me llamen "maricón", incluso que asépticamente me tilden de "homosexual"» (Sanz, 2012a: 59). Sanz realiza, en el segundo volumen de la saga, desde su título, Un buen detective no se casa jamás, un ejercicio de teorización sobre la representación de la sexualidad en la novela negra. La escritora reflexiona sobre el hecho de que Chandler establece, como características de los personajes de novela negra, que el detective se debe resistir al amor (que no al sexo), sin embargo, la escritora considera que esta exigencia debería suprimirse para que cada creadora o creador encuentre la fórmula que mejor se ajuste a su historia. 
Un buen detective no se casa jamás es un axioma. Una recomendación. Un hecho indiscutible. Es el epifonema con que Raymond Chandler pretende resumir las estrategias que deben vincular sentimentalmente a los personajes en las novelas de detectives. Chandler habla del amor-odio que el detective siente hacia la mujer fatal. Habla de que la atracción e incluso el afecto deben ser impulsos que coloquen el detective en situaciones de peligro. Siempre al filo de la navaja. A punto de despeñarse. El amor es un sentimiento que acrecienta y expone la vulnerabilidad de un héroe que es un antihéroe que es un héroe. El detective no puede disfrutar de una seguridad afectiva. No puede comprarse un chalecito adosado con jardín y una secadora. No puede amar a una mujer con delantalito blanco que le prepare palitos congelados de merluza para cenar. Chandler era un tipo muy inteligente y un magnífico escritor. Pero quizá no debería haber dado instrucciones. Quizás hubiera sido mejor que permitiese a cada escritor buscar sus propias fórmulas. A mí me gustan los escritores ilegales. Los que se saltan las normas... (Sanz, 2012b: 44).

Si es así, a Marta Sanz le gustan los tres personajes centrales que analizamos en la tesis, ya que en todos los casos rompen con la premisa de Chandler. Las dos policías, Petra Delicado y Clara Deza, son de alguna manera exponente atípicas de la hard-boiled. La subinspectora Deza está casada desde el inicio de la historia, lo que la sitúa en una posición contraria a la del detective clásico de novela negra que tiene un nuevo interés sexual-amoroso en cada entrega. La representación de la sexualidad del matrimonio es altamente convencional. La misma Clara comenta que el sexo es bueno, pero no menciona ninguna práctica extravagante o fuera de lo considerado «normal». Esto choca con las prácticas sexuales de la red de prostitución de alto standing que investiga, que ponen en práctica sus fantasías más extremas utilizando cuero, látigo... Literariamente nos encontramos con una consciente o inconsciente representación del bien y del mal a través de las prácticas sexuales estándares o marginales.

Petra Delicado ejemplifica mejor el detective típico de hard-boiled, por un lado, con los estallidos de ira violentos y descontrolados, llegando, en alguna ocasión, a la violencia física, pero manejando extraordinariamente la violencia psicológica y, por otro, con una vida sexual activa, independiente y, por momentos, desinhibida, que cambia con el avance de la serie y su matrimonio con Marcos. 
En este sentido Petra es similar a otros personajes que hemos mencionado, como Mariana de Marco, y que en parte representan la fantasía de muchas mujeres que quieren romper los convencionalismos que impone la sociedad patriarcal en las relaciones sexuales. De hecho, Petra tiene un affaire nuevo en casi todas las entregas: un veterinario, un compañero ruso, un filósofo con pretensiones... Incluso una vez casada busca sexo sin amor con el ispettore italiano. En este caso, será Fermín Garzón, su subalterno, quien tenga relaciones más convencionales (después de unos escarceos amorosos en Días de perros (1997) no encontrará el amor nuevamente hasta que conozca a Beatriz Enríquez, en Serpientes en el paraíso (2002), con la que se casará finalmente). Cuando Petra le explica su teoría sobre la separación entre el sexo y las emociones se escandaliza porque considera que las mujeres no deben hablar así, mostrando su educación machista. Lo cierto es que este tipo de conversaciones, que no son insólitas entre ellos, podrían ser consideradas hoy día como acoso en el entorno laboral porque hacen que una de las partes se sienta incómodo.

-Los amantes ya no son lo que eran, Garzón, eso de retirar a la querida del mundo laboral creo que está de capa caída. Una cena de vez en cuando en el Ritz es suficiente. Como no desgrava...

-Entonces hasta yo podría permitírmelo.

-¿Cómo soluciono, qué?

-El problema del sexo y la emotividad. Nunca me comenta nada.

Me miró deseándome la rueda de molino para que me tiraran al mar.

-Sinceramente, inspectora, nunca pensé que se atreviera a preguntarme una cosa así. Es impropio de usted.

-¿Lo he escandalizado?

-Sí.

-No comprendo por qué. 
-En primer lugar es usted una mujer, espero que no se le haya olvidado. Y, además, es usted mi superior, eso estoy seguro de que no se le ha olvidado. De modo que...

-Sí, perdóneme, lleva usted razón, ha sido una vulgaridad (Giménez Bartlett, 2000 [2013]: 774).

Giménez Bartlett opta por una representación de la sexualidad muy convencional, lejos de transgresiones para los personajes protagonistas. La introducción de la homosexualidad se relaciona con el subinspector Garzón. Su hijo visita a su padre para presentarle a su novio y Garzón no gestiona muy bien el asunto. «Capté a la primera aquel pretendido hermetismo y deduje que su mancha familiar estaba relacionada con la homosexualidad de su hijo. Con toda probabilidad era conveniente que hablara con él sobre el tema, que le ofreciera aliento racional, pero el aire de desgracia que le confería a aquel asunto me resultaba intolerable» (Giménez Bartlett, 2004 [2013]: 1220). Petra intenta hacer entrar en razón a Fermín exponiendo que su hijo es «estupendo, inteligente y brillante», y le reprocha: «como la costumbre es que se case y le dé a usted muchos nietos, es incapaz de aceptar su homosexualidad» (Giménez Bartlett, 2004 [2013]: 1275). Petra confiesa: «Comprendí que nunca asimilaría tener un hijo gay y me di cuenta del dolor que eso le provocaba. Afortunadamente, nadie se percataba de lo que estaba pasando, nadie excepto el propio Alfonso, por supuesto...» (Giménez Bartlett, 2004 [2013]: 1282). Pero esta relación también entra en los parámetros mainstream. Serán los individuos que están implicados en los crímenes quienes realicen prácticas sexuales «depravadas» y criminales, abusos de menores, violaciones...

En las novelas de Mercedes Castro es significativa la relación de Teresa con Simón, jefe de la sección de arte de una revista de moda, un mexicano con un aspecto que parece el cruce entre Truman Capote y Dumbo (Castro, 2010: 201). Su padre lo internó en un centro psiquiátrico donde recibió terapia de electroshock, encierros prolongados y sedantes, a pesar de lo cual «contra todo pronóstico, logró sobrevivir a ese infierno y preservar su identidad sexual» y salir fortalecido, aunque presenta una «extraña fragilidad» por lo que los amigos intentan protegerlo. Este personaje dañado por su padre era el consejero de Teresa cuando 
ella afirma: «me jactaba de tener sentimientos, y mi paño de lágrimas en esos días aciagos en que comprendí que podía llorar» (Castro, 2010: 206-207). Como se puede observar es un personaje secundario y construido de manera estereotípica, pues presenta las características habituales en un personaje homosexual tipo: problemas con su familia al declarar su condición sexual, animoso, divertido, sensible... Es decir, la representación de la sexualidad homosexual desde una perspectiva mainstream.

De forma general, la novela negra, especialmente la hard-boiled, complementa al detective sexualmente activo y enamoradizo con el personaje de la femme fatale, una mujer atractiva sexualmente que utiliza la hipersexualización que desprende para atrapar a los protagonistas y conseguir convencerles para que actúen según sus intereses. En Mantis (2010), se rompe este criterio colocando a la femme fatale como protagonista. Una figura distante, egoísta y dura, en cierto modo una actitud heredada de la conducta de su madre (como hemos mencionado en el apartado de la maternidad). La propia Teresa Sinde confiesa: «No soy ninguna heroína desprendida y emotiva, madura y entera [...] no valgo para sacrificios» (Castro, 2010: 358). «Me imagino más bien como la última representante de una raza [...] incompleta y ridícula, triste sombra de mí misma con maneras de mujer pantera, un ser fronterizo y sanguinario de voz rota y melancólica una alimaña entre lo piadoso...» (Castro, 2010: 11). Teresa es capaz de convencer a los hombres para que la sigan hasta su fatal final, sin embargo no muestra apetitos sexuales extraños o periféricos.

En este punto, nos parece interesante apuntar la posibilidad de profundizar en el análisis de los personajes sexualmente periféricos como una futura línea de investigación sobre todo pensando en personajes homosexuales, escasos todavía en la novela negra en general y la novela negra española en particular, aunque en los últimos años esta situación se esté revisando. En este capítulo hemos mencionado a varios investigadores homosexuales como, por ejemplo, Amaiz Ezpaldoi, bisexual, creada por Itxaro Borda, o el detective privado Arturo Zarco, gay, creado por Marta Sanz. 


\subsection{Síntesis}

En este capítulo hemos desarrollado cómo, aunque la novela negra cuente con una estructura establecida, entendemos que si la escritora es una mujer cabe la posibilidad de que se maticen ciertos elementos introduciendo una realidad diferente. Sobre todo si el personaje femenino protagonista presenta unos valores y unas actitudes propias de la sociedad patriarcal en la que está inmersa pero a la que, al mismo tiempo, se enfrenta.

Hemos mostrado cómo, en el caso español, habrá que esperar hasta la Transición (1978) para que se publique, otra vez, novela negra. Así, en estos años, resurge el interés por dicho género novelesco, al mismo tiempo que las reivindicaciones de los movimientos feministas de ocupación de los espacios públicos, especialmente la ocupación de espacios en los que todavía no habían destacado las mujeres. Así encontramos, por ejemplo, a Lourdes Ortiz, María Antonia Oliver, Itxaro Borda o Rosa Montero, todas ellas autoras de novelas transgresoras y atravesadas por una perspectiva crítica feminista por la sexualidad de las protagonistas, la ironía que atraviesa toda la historia, y otras líneas de trabajo.

Durante los últimos años del siglo XX y principios del XXI, cada vez más escritoras se han sumado a la corta lista de autoras de novela negra en nuestro país. Así pues, en esta investigación hemos centrado nuestro análisis en torno a dos autoras: Alicia Giménez Bartlett (creadora de Petra Delicado) y Mercedes Castro (creadora de Clara Deza y Teresa Sinde).

Por su parte, Petra Delicado se presenta como una persona voluntariosa, obstinada, cabezota, profesional, tenaz, es consciente en todo momento de su posición en un mundo de hombres. Alérgica a la maternidad hasta que conoce a su tercer marido, un arquitecto polidivorciado con cuatro hijos.

Clara Deza es subinspectora de policía, casada y que tiene como compañero a un ex. Teresa Sinde es la cocinera propietaria de un restaurante (Barbantesa) de 
éxito, estrella de la televisión, posee un lado oscuro y cuando conoce a un hombre se transforma en una femme fatale.

El elemento unificador de los tres personajes radica en que son las protagonistas de la novela y pertenecen a una clase social acomodada de la que reniegan. Para analizarlas, las hemos abordado desde varias dimensiones: la profesionalidad, la asimilación-diferenciación de sus conductas, la maternidad, las relaciones personales, especialmente con otras mujeres, y la violencia de género.

Las sociedades patriarcales establecen un contrato social por el que las mujeres y los hombres ocupan diferentes espacios (privado y público) de producción y reproducción encerrándolas en el ámbito privado, doméstico. Petra Delicado es inspectora de policía (antes abogada) como Clara Deza, y Teresa Sinde es cocinera. Todas ellas se mueven en ese espacio público. Este aspecto nos parece significativo porque la popularidad de la novela negra puede ser empleada para visibilizar las cuestiones de género y hacer una crítica de la situación de desigualdad.

Ya en el capítulo, hemos destacado lo enunciado por (Venkataraman, 2010) quien, siguiendo a Kathleen Klein, afirma que es necesario que las autoras empleen la literatura popular, como es el género de novela negra, para la denuncia y exposición de la diferencia de género entre mujeres y hombres, impuesta por las sociedades y la cultura, de manera que hagan conscientes a sus lectoras y lectores de la desigualdad existente y de la labor que desempeña el feminismo en el fin de esta desigualdad.

Nuestro análisis parte de esta misma posición, por ello observamos en los personajes de Petra, Clara y Teresa unos modelos positivos, al visibilizar situaciones cotidianas en las que las mujeres se pueden ver reflejadas y de ese modo reflexionar sobre su situación. Asimismo, describen las diferentes estrategias que adoptan las protagonistas ante las situaciones que se les presentan «a diario».

Los tres personajes nos permiten visibilizar las dificultades de las mujeres en ámbitos laborales masculinizados, lo que nos parece positivo y ayuda a la toma de conciencia de la desigualdad y la pertinencia de los valores de los feminismos, 
aunque no se verbalice como tal, sino que se describan las relaciones cotidianas en las que se observa esta discriminación.

¿Cómo se manifiestan los personajes que estudiamos, ajustándose a los valores asignados por la sociedad patriarcal o adoptando aquellos que no son considerados propios de su género? Alicia Giménez Bartlett y Mercedes Castro, sin exponerla explícitamente, realizan una crítica a esta categorización de los géneros. Petra Delicado, de hecho, señala que esta división sexual le parece perversa, tanto para las mujeres como para los hombres.

Pero la contradicción que soportan las mujeres en un sistema patriarcal hostil se evidencia en el caso de Petra al describirla como una policía dura, que se niega a tener pálpitos. Los personajes de Castro son, por el contrario, más emocionales. Clara Deza incluso utiliza esta sensibilidad para construir sus teorías.

Teresa Sinde es un personaje completamente diferente. Se trata de la mujer fatal que cual mantis depredadora es capaz de devorar al macho que se le pone por delante. La culpabilidad que puede sentir por ello la maneja mediante la creación de los platos que sirven de título a cada uno de los capítulos. Como profesional no tiene competencia, pero como persona está herida y llena de contradicciones, lo que no le impide ser funcional en el restaurante y el programa de televisión, así como en el resto de actividades que realiza.

De este modo, podemos constatar que las protagonistas de las novelas analizadas aunque adoptan, en ocasiones, actitudes que se consideran propiamente masculinas, suelen reivindicar también una parcela de identidad propia como mujeres.

El estereotipo femenino tiene en la maternidad uno de sus fundamentos, es decir, la capacidad de tener hijos determina la conducta que la sociedad considera válida en una mujer. Cada uno de los personajes se posiciona de una manera diferente ante ésta. Petra se muestra ambivalente, en un primer momento rechaza la idea de ser madre, pero cuando conoce a Marcos entra en las dinámicas de la maternidad. 
Castro hace que ambos personajes tengan un «falso embarazo», tras lo cual toman caminos distintos, aunque próximos a la madre-monstruo. En Y punto (Clara Deza, 2008) con una suegra que la presiona para que cuide a su hijo, y en Mantis (Teresa Sinde, 2010), la maternidad personificada en Ofelia, madre de Teresa Sinde, se convierte en algo atroz frente a lo que se cobra algunas venganzas. La indiferencia y crueldad la hieren profundamente, pero Teresa tiene a su alrededor otras mujeres que pueden hacer esta función, su niñera cuando es pequeña y su secretaria-mano derecha en la edad adulta.

Tal y como hemos mostrado en el presente capítulo, el sentimiento de sororidad, de complicidad por el hecho de ser mujeres en un mundo hostil, es evidente en las novelas de Castro y está más desdibujado en las de Giménez Bartlett por la determinación de soledad de la protagonista. A pesar de ello, sí existe un sentimiento de «hermandad» incluso con mujeres que no son conocidas (como cuando Teresa sale en defensa de una modelo a la que agrede su noviofotógrafo o cuando Clara conoce a la novia de Carlos, su ex, y siente cierta empatía porque la joven sólo ve las cosas buenas del inspector).

Al mismo tiempo, cabe destacar que uno de los problemas más importantes en nuestros días es la violencia de género. Las dos autoras, Castro y Giménez Bartlett, presentan diversas formas de machismo, desde los pequeños machismos cotidianos que pasan desapercibidos, como el lenguaje, hasta la violencia más explícita. De hecho, Castro opta por convertir a Teresa Sinde en una especie de femme fatale justiciera que protege a otras mujeres y a sí misma de los «depredadores», convirtiéndose ella en una mantis con ese propósito.

A pesar de todo, los tres personajes, Petra Delicado, Clara Deza y Teresa Sinde, rompen la norma y tienen parejas estables. En este sentido las relaciones que se muestran son plenamente convencionales y dejan las prácticas sexuales menos convencionales para criminales y/o las víctimas de los crímenes.

Sin embargo, el gran paso en todos los ámbitos de la vida y, en este caso en la literatura sería plantear a mujeres profesionales, madres, esposas o no madres o no esposas, y que esto fuera una decisión propia. El tema de la soledad se presenta como una decisión/opción del ser humano. La igualdad real se verá reflejada 
cuando se plantee una protagonista femenina que decide tener una profesión, una familia (o no) y nadie se cuestione esto, sino que se dé por hecho que tienen derecho a moverse en ambos ámbitos. 



\section{CAPÍTULO 5. CONCLUSIONES Y FUTURAS LÍNEAS DE INVESTIGACIÓN}

5.1. Conclusiones

5.2. Otras líneas de investigación 



\section{CAPÍTULO 5. Conclusiones y futuras líneas de investigación}

Una vez expuestos los resultados de la investigación, vamos a recoger las principales ideas planteadas a lo largo de este investigación para responder a la cuestión que nos planteábamos en el inicio de la tesis: identificar los modelos de mujeres que aparecen en las novelas negras contemporáneas escritas por Alicia Giménez Bartlett y Mercedes Castro, y comprobar si estos son o no transgresores.

\subsection{Conclusiones}

Al comienzo de esta tesis nos planteamos la identificación de los modelos femeninos que aparecen en la novela negra de escritoras en España hoy día, y si estos se pueden convertir en modelos positivos que influyan en un lento, pero continuado, cambio social hacia la inclusión de las mujeres en todos los ámbitos de la vida.

Para conseguir nuestro objetivo hemos optado por acotar los elementos de análisis, que hemos reducido a seis: profesionalidad, asimilación/diferencia, maternidad, sororidad, violencia de género y sexualización de las protagonistas.

El primer paso ha sido clarificar el término género negro. Al repasar la literatura sobre la controversia del término que identifica al género encontramos que en el caso español han aparecido desde los años ochenta del siglo XX diferentes conceptos: novela criminal, novela policiaca clásica, novela policiaca, novela negra. En nuestro caso, seguimos a autoras como Hart (1987) o Janerka (2010), porque consideramos, como Hart, que la novela negra actual tiene elementos realistas y de crítica social (aunque no siempre se desarrollen en ámbitos urbanos), $\mathrm{y}$, siguiendo a Janerka, porque género negro es el término que mayoritariamente utilizan crítica, ámbito empresarial y aficionadas y aficionados 
para referirse a esta literatura. A pesar de lo cual, al realizar la revisión histórica de la evolución del género haremos referencia al término más utilizado por la crítica en su momento, de este modo, diferenciaremos subtipos de novela negra con características propias.

Tras la precisión terminológica hemos repasado la evolución del género desde su origen hasta la actualidad, haciendo especial hincapié en el ámbito internacional.

\section{Origen del género negro}

La crítica sitúa el nacimiento del género negro en la Inglaterra industrial de finales del siglo XIX. Será Edgar Allan Poe el que escribirá un relato, «Los crímenes de la calle Morgue» (1841), donde se apunta la estructura de la historia, así como las características de los personajes del género. La creciente delincuencia provocada por la crisis social, económica y de identidad supone la necesidad de profesionalizar a la policía. En estas historias, se introduce este creciente interés por la ciencia forense, que es utilizada por las investigadoras e investigadores aficionados para resolver los casos junto a las deducciones racionales. Es el momento del triunfo del racionalismo. A pesar de todo, estas historias tienen un componente lúdico explotado por las escritoras y escritores y que permite interactuar con las lectoras y lectores (López Martínez, 2006; James, 2009 [2010]).

Este primer subtipo de novela negra se denomina novela enigma (Resina, 1997; Rodríguez Pequeño, 1995), precisamente porque la o el protagonista debe resolver un misterio: ¿quién es el asesino? Rápidamente, este género se populariza extendiéndose tanto por el ámbito anglosajón como europeo continental, especialmente Francia: Arthur Conan Doyle, Agatha Christie, Maurice Leblanc, entre otros, son los nombres esenciales en esta etapa.

La importancia de las novelas por entregas es fundamental para el desarrollo del género. Será Charles Dickens con Bleak House (1852-1853) quien ayuda a sentar las bases del género negro. 
Al repasar sucintamente las publicaciones de la época, observamos que no existen diferencias significativas entre las historias que plantean o los personajes que crean unas y otros. Las características que comparten consisten en que se trata de investigadoras o investigadores aficionados con dotes especiales para la observación. En un primer momento, suelen representarse como extravagantes, con dotes extraordinarias, el arquetipo básico sería Sherlock Holmes. Además, suelen tener un compañero que les hace destacar, aún más. Según avanza el género se introducen elementos psicológicos.

La novela negra que analizamos en nuestro corpus de trabajo contiene alguno de estos elementos, pues suelen tener un compañero (tanto Petra Delicado como Clara Deza).

En Estados Unidos, el género evolucionará hacia la denominada novela hard-boiled, que se caracteriza por el realismo y el compromiso social. Algunos críticos hablan de una novela denuncia que se desarrolla en un ámbito urbano, y el interés radica en los personajes y no tanto en la resolución del caso. El investigador se profesionaliza, aparece el detective privado como protagonista, un personaje «duro», leal, violento, solitario y con una psicología «torturada» (Martín Cerezo, 2006; González, 2006; James, 2009). Los máximos exponentes de este subtipo son Phillip Marlow y Sam Spade.

También característica de este subtipo de novela negra es la femme fatale, un arquetipo que representa a una mujer egoísta y manipuladora, que suele relacionarse con el investigador. Ésta será la principal forma en que aparecen las mujeres en esta etapa de la evolución de la novela negra.

Observamos que las protagonistas de las novelas de Alicia Giménez Bartlett y Mercedes Castro cumplen algunas de estas características y se distancian de otras de las particularidades de este tipo de personajes. Petra Delicado es «dura», violenta, en ocasiones, solitaria, con fuertes principios morales. Teresa Sinde es una declarada femme fatale, mientras Clara Deza se presenta como un personaje más alejado del arquetipo.

Con el nacimiento de la hard-boiled, se inicia una relación simbiótica entre la literatura y el cine. El personaje protagonista y la violencia que emana de estos 
relatos resultan muy atractivos para el medio audiovisual. Las novelas de Alicia Giménez Bartlett, siguiendo esta tradición, han sido adaptadas a la televisión.

Pero el subtipo que mejor desarrolla esta relación con el cine es la novela negra de suspense. El mayor exponente fue Alfred Hitchcock, que rueda tanto guiones propios como adaptaciones de novelas cuya característica principal es el misterio. Se trata de historias inmersas en un ambiente psicológico angustioso, algo que encontramos precisamente en Mantis (2010), de Mercedes Castro.

Para finalizar, repasamos algunas novelas negras localistas: nórdica, africana, japonesa e india, por mencionar sólo unos casos del panorama global, en las que observamos que comparten características con las expuestas anteriormente, a las que añaden particularidades propias de su entorno.

\section{Novela negra en España}

A continuación, hemos repasado la evolución de la novela negra en España hasta llegar a nuestros días. Los inicios en España son similares a los del resto de países europeos y Estados Unidos. Fernando Colmeiro (1994) sitúa la aparición del género negro en España con la publicación de la novela corta de Pedro Antonio de Alarcón, El clavo (1853). En este primer momento, igual que sucede en el mundo anglosajón y el ámbito europeo (occidental), también hay una mujer que escribe novela negra, concretamente Emilia Pardo Bazán. La escritora, crítica con la novela policiaca clásica, introduce a las características propias del género, como el juego de investigar junto a un detective no profesional, personajes con una psicología más compleja, aportación que no se tendrá en cuenta, y no se incluirá en los relatos hasta más tarde. Sí vemos comprobado que no aparecen personajes protagonistas femeninos como investigadores, incluso en las novelas de Pardo Bazán el detective es amateur, pero varón. Los personajes femeninos aparecen como las criminales que hay que atrapar y castigar (dentro del marco de la legalidad).

Es obvio que, no es el caso de las novelas que analizamos, en las que las investigadoras protagonistas son mujeres: Petra Delicado y Clara Deza. Como 
contrapunto, Teresa Sinde es la responsable de los crímenes, sobre la que no se cierne ningún castigo ejemplarizante.

La situación política española entre las décadas de los treinta y setenta, Guerra Civil y Dictadura, provocan un parón en la evolución del género en España. Manuel Pedrolo introduce una novela negra más audaz que la anterior en la que recurre al punto de vista del sospechoso y critica duramente el sistema policial y judicial. Aunque será con la publicación de Tatuaje (1974), de Manuel Vázquez Montalbán (creador de Pepe Carvalho), cuando comienza progresivamente a tomar fuerza, tal vez por primera vez, en el país. Esta nueva novela negra es muy parecida a la hard-boiled de Chandler y Hammett y contiene un fuerte componente social, es como un diario de la situación social, y la crítica social se convierte en fundamental (Hart, 1987).

En las novelas que componen el corpus de esta tesis vemos como Petra Delicado y Fermín Garzón, su compañero, reflexionan en sus conversaciones sobre las desigualdades, aunque no sea el principal tema de las novelas de Giménez Bartlett, salvo en Un barco cargado de arroz (2004), donde se trata de manera abierta la problemática de la inmigración. Y, de hecho, un tema social recurrente tanto en la saga de Petra Delicado como en Y punto (2008) es la desigualdad entre géneros.

En este capítulo también repasamos elementos tangenciales, pero que consideramos importantes para el desarrollo de la literatura negra, en general, y la literatura negra escrita por mujeres, en particular. Los festivales del género sirven para dar visibilidad a los escritores de novela negra, y también a las escritoras. Y los premios permiten, no solamente, dar visibilidad a las escritoras premiadas, sino además distribuir estas novelas para que lleguen a la mayor cantidad de público posible.

Finalmente repasamos las novelas negras periféricas en España: novela negra catalana, novela negra gallega y novela negra en euskera. En este apartado hemos visto que el desarrollo de estas literaturas es similar y se influyen mutuamente. 
Las dos autoras de nuestro corpus han recibido premios literarios. Alicia Giménez Bartlett tiene numerosos reconocimientos: Premio Women Fiction Festival de Matera Award (Italia) (2006) por la Serie Petra Delicado, Premio Grinzane Cavour (Noir) a la Mejor Novela Extranjera (2006) por Un barco cargado de arroz, Premio Raymond Chandler (2008) por la Serie Petra Delicado, Premio Internazionale Fregene (2009), Premio Pepe Carvalho (2014), sólo en el ámbito de género negro.

Mercedes Castro fue galardonada por su novela $Y$ punto (2008) con la distinción a mejor ópera prima en castellano en el Festival de Chambéry (Francia). Además esta obra recibió numerosas alabanzas de la crítica.

\section{Análisis de las conclusiones de las variables de estudio}

Llegamos al tema central de la tesis, tras repasar la evolución de la novela negra, de lo general a lo particular (en España), y recordar brevemente las dificultades que han encontrado las mujeres a la hora de escribir y las reivindicaciones que desde su posición de escritoras han realizado sobre la situación de desigualdad de las mujeres de su época. Así, para detectar los modelos femeninos protagonistas en las novelas negras contemporáneas, repasamos la teoría crítica feminista, para establecer unos elementos que nos puedan ayudar a configurar este modelo. Tras las lecturas de diversos trabajos (Beauvoir, 1945 [2011]; Badinter, 1981; Butler, 1990; Lagarde, 1993; Sau, 1995; Amorós, 1997; Juliano, 1998; Puleo, 2005; Torras 2007; Caballero Guiral, 2012) consideramos que las variables adecuadas son las siguientes: profesionalidad, asimilación/diferenciación, maternidad, sororidad, violencia de género y la sexualización de las protagonistas.

En el capítulo uno, revisamos la novela negra, en el capítulo dos nos centramos en la evolución de la novela negra en España, en el tercer capítulo exponemos el corpus de la tesis presentando a las escritoras y su obra, y en el cuarto capítulo estudiamos qué sucedió durante la Transición con la novela negra española y los personajes protagonistas femeninos. Aparecen una serie de autoras 
que crean investigadoras transgresoras, como Lourdes Ortiz con Picadura mortal (1979), María Antonia Oliver (1969- ) y el personaje de Apolònia Guiu (Lònia) (Estudi en lila, 1985) o Itxaro Borda (1959- ), que crea a Amaia Ezpeldoi. Las novedades que presentan están en su sexualidad, son lesbianas o bisexuales, o el ámbito en el que desarrollan su actividad, el mundo rural. Veremos que en ese sentido las protagonistas del corpus de esta tesis (Petra Delicado, de Alicia Giménez Bartlett; Clara Deza y Teresa Sinde, de Mercedes Castro) muestran comportamientos más convencionales, heterosexuales, y residen en grandes ciudades. Otras escritoras introducen el elemento de la teoría crítica feminista de manera evidente en sus novelas, como es el caso de Rosa Montero. Hemos observado que Alicia Giménez Bartlett no es tan explícita en su saga al tratar el tema de la reivindicación de los derechos de las mujeres. Mercedes Castro se muestra más decidida a la hora de encuadrar a sus personajes dentro de demandas de género. Pero no serán sólo las escritoras las que introducen personajes femeninos en sus novelas, por ejemplo Lorenzo Silva (1966- ) crea la serie de los Guardia Civiles Bevilacqua y Chamorro, y José María Guelbenzu, la serie de la juez Mariana Marcos. En todos estos casos las protagonistas son representadas como mujeres autónomas y profesionales, en la línea de las detectives y la femme fatale que estudiamos.

Tras revisar de forma concisa qué está sucediendo en el ámbito editorial, nos centramos en las autoras contemporáneas objeto de nuestro análisis, Alicia Giménez Bartlett y Mercedes Castro, así como en los personajes que han creado, Petra Delicado, en el primer caso, y Clara Deza y Teresa Sinde, en el segundo.

\section{Mujeres profesionales: Petra Delicado, Clara Deza y Teresa Sinde}

La teoría crítica feminista nos plantea que las sociedades patriarcales establecen dos espacios diferenciados, un espacio privado que se circunscribe al ámbito doméstico, y que sostiene al ámbito público de la producción y reproducción. El primero, de manera tradicional, se asigna a las mujeres y el segundo a los varones, lo que resulta injusto para aquellas que sostienen el espacio de la toma de decisiones (en diversas profesiones, en política, etc.). 
Las tres protagonistas son profesionales. Clara Deza y Petra Delicado son miembros del cuerpo de la Policía Nacional. En el caso de Petra, además, había ejercido como abogada. Teresa Sinde es cocinera. Los tres personajes son modelos positivos que permiten a las mujeres identificarse con las situaciones cotidianas que viven en el mundo laboral. Del mismo modo, las estrategias que las protagonistas adoptan en estas circunstancias pueden plantear cómo responder a ellas.

En el ámbito laboral, tanto Petra Delicado como Clara Deza y Teresa Sinde, viven en un entorno laboral masculinizado que les es hostil en muchas ocasiones, lo que lleva a situaciones de desigualdad. Giménez Bartlett y Castro colocan a sus personajes en posiciones que les permiten crear conciencia de feminismo sin mostrarlo de forma explícita.

Otro aspecto en común es que las tres protagonistas, sobre todo, Petra y Clara, relegan sus vidas privadas a favor de sus trabajos. Siempre surge un caso que atender en medio de unas vacaciones, una discusión, mientras hacen el amor, o en cualquier otra situación personal. A pesar de ello, Petra se muestra encantada de estar en el servicio activo, lo que también les ocurre a Clara y a Teresa, que no se queda atrás y disfruta creando platos.

En las novelas se constata que, a pesar de la profesionalidad que muestran, las protagonistas se encuentran con dificultades derivadas de su condición de mujeres que trabajan en espacios masculinizados. Cada una de ellas se enfrenta a situaciones de discriminación por parte de los compañeros, y a la discriminación sistémica de sus profesiones de diferentes maneras. En ocasiones se mimetizan con las costumbres masculinas, en otras se resisten e intentan poner en valor su identidad femenina.

¿Cómo se manifiestan los personajes que estudiamos ajustándose a los valores asignados por la sociedad patriarcal o adoptando aquellos que no son considerados propios de su género? 
En relación con el sistema sexo/género y la división sexual del trabajo, observamos que las escritoras, Alicia Giménez Bartlett y Mercedes Castro, critican el ordenamiento que la sociedad patriarcal hace de los espacios público y privado y la caracterización de los individuos que están tradicionalmente asignados a cada uno de ellos. Así, se supone que las mujeres que ocupan el espacio doméstico (privado) deben tener condiciones que permitan realizar tareas de cuidado, mientras que los hombres desarrollan valores relacionados con la confianza y la autonomía para poder desenvolverse en el espacio de toma de decisiones (público).

Lo más interesante, en este caso, es observar que los personajes femeninos deben adoptar conductas que se consideran impropias de su sexo para conseguir conquistar el espacio público, asimilando comportamientos violentos y alejados de la sensibilidad y el cuidado que se entiende más propio de las mujeres. En este caso, también es diferente el modo en que se enfrentan Petra Delicado y los personajes de Castro, Clara Deza y Teresa Sinde, a esta situación. Mientras la primera asalta mediante la fuerza, si es necesario, su espacio en el ámbito profesional, Clara y Teresa se muestran menos contundentes, no por ello, menos efectivas. Simplemente, observamos diferentes destrezas para conseguir el mismo objetivo: ser respetadas. Todas ellas se muestran más próximas al estereotipo femenino de las sociedades patriarcales en las relaciones personales.

A esto hay que añadir un aspecto que nos parece de especial relevancia, pues Giménez Bartlett, en boca de Petra Delicado, además, visualiza que este sistema afecta también a los varones. Para ella esta perversión del sistema se personifica en Fermín Garzón, su compañero, sometido durante años a la rigidez de una sociedad tradicional que le ha impedido llegar a ser feliz.

A la vista de estos datos, podemos afirmar que las tres protagonistas adoptan una actitud de asimilación o diferenciación de los roles tradiciones según convenga a sus propósitos y necesidades en cada momento, es decir, se adaptan a cada situación que viven.

Representación de la maternidad en Alicia Giménez Bartletty Mercedes Castro 
El patriarcado tiene en la maternidad uno de sus fundamentos tradicionales, siendo uno de los aspectos que se vinculan con mayor determinación a las mujeres.

Cada uno de los personajes (Petra Delicado, Clara Deza y Teresa Sinde) se posiciona de una manera diferente ante la maternidad. Petra se muestra ambivalente, en un primer momento rechaza la idea de ser madre, pero cuando conoce a Marcos (quien se convertirá en su tercer marido) entra en las dinámicas de la maternidad.

Castro hace que sus personajes (tanto Clara Deza como Teresa Sinde) tengan un «falso embarazo», tras lo cual toman caminos distintos: Clara no descarta que pueda ser madre, y Teresa se niega a traer a un niño al mundo para que sufra como ella lo ha hecho. La representación de la maternidad se concreta ocasionalmente en la figura de la madre-monstruo. Giménez Bartlett presenta esta imagen de madre que abusa de sus hijos e hijas en Nido vacío (2007), por ejemplo, con una madre que vende a su hija a una red de pederastas. Mercedes Castro opta por una representación de esta figura más próxima a la definición que realiza Barbara Creed (1993 [2012]) en la novela Y punto, donde situamos esta figura en el personaje de la suegra de Clara, Esmeralda, que trata a su hija política de forma despótica para que cuide a su hijo, el marido de Clara, Ramón. Por otro lado, en Mantis, sí aparece una figura clásica de madre-monstruo personificada en Ofelia, madre de Teresa Sinde, que convierte la relación con su hija en algo atroz. De adulta, Teresa se cobra venganza por esta situación de despotismo a la que la tenía sometida. A pesar de ello, a la Teresa adulta, la indiferencia y la crueldad la hieren profundamente, situación que supera gracias a las mujeres de su entorno que realizan la función maternal: su niñera cuando es pequeña, y su secretaria-mano derecha en la edad adulta.

Esta relación que Teresa Sinde entabla con las mujeres de su entorno es maternal, en parte como respuesta a las redes solidarias que crean algunos grupos de mujeres.

Representación de las relaciones de los personajes femeninos en Alicia Giménez Bartletty Mercedes Castro 
El sentimiento de sororidad, de complicidad por el hecho de ser mujer en un mundo hostil, es evidente en las novelas de Castro y está más desdibujado en las de Giménez Bartlett, por la determinación de soledad de la protagonista y su denuedo por ser siempre profesional.

Petra tiene en su equipo de trabajo a dos oficiales (Yolanda y Sonia) para las que es como una mentora. Especialmente Yolanda la trata como un modelo a la que seguir, admiración que en cierto modo es recíproca, pues Petra la considera una chica inteligente y muy capaz. Incluso intenta protegerlas, pero en ocasiones su actitud más que de solidaridad y cooperación es incluso paternalista, algo a lo que las jóvenes oficiales no hacen demasiado caso.

Mercedes Castro introduce de manera mucho más decidida este comportamiento de sororidad entre las protagonistas y las mujeres que las rodean, y de manera efectiva existe un sentimiento de «hermandad» incluso con personas que no son conocidas (como cuando Teresa Sinde sale en defensa de una mujer en un altercado de violencia de género o Clara Deza se muestra empática con la novia de Carlos, su ex).

Representación de la violencia de género: de la agresión física a los micromachismos

Uno de los problemas más importantes en nuestros días es la violencia de género encarnada en diferentes fórmulas (desde el insulto hasta el asesinato pasando por la violación).

Las dos autoras, tanto Giménez Bartlett como Castro, presentan diversas formas de machismo, desde los pequeños machismos cotidianos que pasan desapercibidos, como pueden ser los presentes en el lenguaje, hasta la violencia más explícita. El enfrentamiento a los micromachismos cotidianos es explícito en Castro, mientras se presenta de forma menos evidente en Giménez Bartlett. Clara Deza se enfrenta a sus compañeros en estas situaciones, incluso a los jefes. La visibilización de esta violencia de género es todavía más patente en Mantis (2010), donde Castro opta por convertir a Teresa Sinde en una especie de femme fatale 
justiciera que protege a otras mujeres y a sí misma de los «depredadores», convirtiéndose ella en una mantis depredadora.

Representación de la sexualidad de las protagonistas en la novela de Alicia Giménez Bartletty Mercedes Castro

Los personajes de Giménez Bartlett (Petra Delicado) y Mercedes Castro (Clara Deza y Teresa Sinde) pertenecen a esta categoría «confusa» al tener profesiones masculinizadas, lo que las obliga a generar mecanismos de adaptación que las protejan. Aunque tenemos que tener en cuenta que estamos hablando de personajes dentro de la novela negra, es decir, unos personajes que deben tener unas características sexuales concretas. Autores como Chandler establecen que los detectives de la novela negra deben ser sexualmente activos, pero sin comprometerse y siempre adoptando una posición preponderante. Petra y Teresa se ajustan a esta premisa mostrándose en ocasiones sexualmente agresivas. Clara, tal vez porque mantiene sus relaciones en el marco de un matrimonio, es activa, pero carece de la violencia de las otras dos. Con todo, lo que sí concluimos es que la representación de las sexualidades resulta mainstream, y las tres acaban con parejas estables, con lo que se adaptan a las normas establecidas socialmente. En este sentido las relaciones que se muestran son plenamente convencionales.

Así pues, observamos que Alicia Giménez Bartlett y Mercedes Castro crean personajes que afirman no ser feministas, pero sus actitudes y compromisos sí apuntan de alguna forma a una conciencia feminista y de género, convirtiéndose en modelos positivos para un cambio social progresivo hacia la igualdad.

\subsection{Otras líneas de investigación}

No podemos terminar sin apuntar de forma sucinta algunas posibles líneas de investigación que podrían sustanciar futuros trabajos. La primera línea que 
querríamos seguir explorando tras la elaboración de esta tesis consistiría en ampliar el corpus de autoras de las que analizaríamos los mismos aspectos que hemos trabajado aquí: profesionalidad, asimilación-diferencia, maternidad, sororidad, violencia de género, y sexualidad de las protagonistas, con series de otros personajes como Amaia Salazar (Dolores Redondo), Ada Levy (Clara Peñalver), o Mariana de Marco (José María Guelbenzu), entre otras.

Asimismo podemos revisar, para futuras líneas de trabajo, qué profesiones tienen las protagonistas femeninas de la novela negra en España y compararlas con otras novelas negras. ¿Existen amas de casa pseudodetectives? ¿Todas son profesionales relacionadas con el ámbito policial o jurídico?

Por otra parte, también consideramos de interés aplicar otra categoría a este corpus, como pueden ser las masculinidades representadas en el mismo. Fermín Garzón es un personaje extraordinario desde la primera entrega de Petra Delicado para analizar las nuevas representaciones de la masculinidad. Dibujado, en un primer momento, como un policía algo cateto y machista, lo cierto es que se muestra más como un espíritu libre que busca un nuevo lugar en el mundo. Garzón, que procede de un estrato social bajo, se mueve bastante bien entre gente rica, clase social a la que pertenece su mujer. El compañero de Petra es un personaje sorprendente. No es tan ignorante como parece y, en realidad, nunca fue tan machista como nos lo pintaban, ¿o sí?

En este análisis de las nuevas masculinidades representadas en las novelas negras consideramos de especial interés el tema de la paternidad. Por ejemplo, en la novela de Eva García Sáenz de Urturi, El silencio de la ciudad blanco (2016), Unai López de Ayala, el personaje protagonista, tiene como uno de sus rasgos definitorios la paternidad perdida. De hecho, esto marca su estado de ánimo y el modo en que se enfrenta a su realidad. Sin olvidar que en la misma novela la autora nos dibuja un segundo personaje de control, si comparamos la experiencia de Unai con la experiencia de la maternidad que tiene su jefa (Alba/Blanca), que también se enfrenta a una pérdida similar.

La relación con la paternidad es únicamente uno de los elementos de las nuevas masculinidades. Para estudiar cómo se caracterizarían este nuevo modelo 
de hombre podríamos usar como corpus el personaje de Unai López de Ayala que hemos mencionado antes junto a, por ejemplo, James, el marido de la inspectora de la Policía Foral Amaia Salazar (Dolores Redondo, 2013a, 2013b, 2014).

Tampoco olvidamos un tema que ha quedado apuntado en esta investigación, pero sin desarrollar: el colectivo de Lesbianas, Gays, Transexuales, Bisexuales e Intergénero (LGTBI). ¿Aparece siempre como víctima? ¿Qué cualidades tienen los detectives o las investigadoras gays y lesbianas? ¿Asimilan las conductas de los detectives clásicos o marcan diferencias con estos?

Por otro lado, nos ha resultado curioso, aunque no lo hemos mencionado en el desarrollo de esta tesis, porque la perspectiva y el objetivo eran otros, la presencia de la comida en la novela negra. Por ejemplo, Nieves Pascual Soler (2013) hace una aproximación a cómo la comida es un elemento fundamental en la serie del inspector Brunetti escrita por Donna Leon. La comida se convierte en esta serie en un elemento identitario que transita entre lo autóctono y lo extraño (extranjero, turístico). «Al hacernos comer del plato de Brunetti, Leon nos permite apreciar con deleite lo real y lo exótico de una Venecia diferente» (Pascual Soler, 2013. 125).

En la serie de Petra Delicado también es un elemento recurrente y fundamental que nos desvela estados de ánimo de los personajes, puntualiza el progreso del caso que investigan, y aporta matices de interés. Petra Delicado y Fermín Garzón van a tabernas infames y a restaurantes de cinco tenedores, sin olvidar que en los viajes al extranjero se convierte en un elemento de hermanamiento con sus colegas, haciendo honor a la gastronomía local.

La comida sirve para tomar un respiro, celebrar algunos acontecimientos, animarse tras un revés, cocinan el uno para el otro y para otras personas, comen con otras personas, socializan delante de un plazo de garbanzos o un whisky. Es un elemento que los une desde el principio e iguala su relación en una estructura como la policial, fuertemente jerarquizada y en la que son jefa y subordinado. Sería interesante analizar si existen prejuicios de género respecto a la comida que encargan. ¿Come Petra más ensaladas que Fermín? ¿Bebe Garzón más que Petra? Cuando invitan, ¿quién lo hace más a menudo y en qué condiciones? 
Si nos centramos en la obra de Mercedes Castro, qué decir de Mantis, donde la comida que prepara Teresa Sinde es un ser vivo que describe su estado de ánimo. Toda la novela es un interesante recetario en el que se rastrean recetas populares o sofisticadas.

Otra línea de investigación estaría relacionada con la violencia de género. Hemos realizado un análisis sucinto sobre este tema en la presente tesis, sin embargo, se puede ahondar mucho más en esta cuestión de manera específica, sobre todo en la novela negra contemporánea. La novela negra como instrumento de denuncia social se debería posicionar contundentemente sobre el tema. Especialmente, cuando hablamos de las formas más extremas de violencia de género que llevan a la muerte de la víctima. ¿Se ha producido algún cambio en la novela negra contemporánea desde la publicación de la Ley Integral contra la violencia de género? En novelas como las anteriormente mencionadas de Dolores Redondo o Eva García Sáenz de Urturi, por ejemplo, se describen casos explícitos en los que hay agresiones por parte del marido, exmarido o la pareja. Al mismo tiempo, se describen actitudes que hacen referencia a micromachismos, como los insultos por ser mujer, por cómo va vestida, y tantos otros aspectos.

Por otro lado, Alicia Giménez Bartlett y Mercedes Castro pertenecen a un grupo de escritoras con formación universitaria aficionadas al género negro tanto literario como cinematográfico, que incluyen en sus novelas. En autoras como Marta Sanz (Black, Black, Black, 2010, y Un buen detective no se casa jamás, 2012) las referencias a películas y novelas negras de hecho definen a los personajes. Cabría analizar si cuando Giménez Bartlett o Castro hacen referencia a clásicos del género están haciendo una labor de teorización sobre la novela negra caracterizando diferentes aspectos de la narración. Hemos observado que Castro tiene una amplia cultura popular y la deja patente en ambas novelas, mencionando a Chandler, por ejemplo. Giménez Bartlett deambula por una amplia variedad de referentes culturales de todo tipo. Pone en boca de Petra Delicado referentes de la denominada «alta cultura», como William Shakespeare, pero también menciona a Sherlock Holmes. Rastrear si estas referencias caracterizan a un género propio podría ser una nueva línea de investigación. 
También nos planteamos como una línea de investigación futura el análisis lingüístico de las series de la juez Mariana de Marco y la inspectora Petra Delicado. Giménez Bartlett sí usa ambos términos (juez/jueza) según el sexo del magistrado o la magistrada que lleva el caso. «Todos aquellos pensamientos reconfortantes iba desgranándolos con indolencia frente al despacho de Flora Mínguez, la jueza que instruía nuestro caso y que, de modo sistemático, siempre había espera a sus visitantes» (Giménez Bartlett, 2000 [2013]: 1496). «Me alegró comprobar que el juez de guardia era Joaquín García Mouriños, un gallego de cierta edad, cordial y cachazudo con el que había coincidido varias veces y me llevaba muy bien» (Giménez Bartlett, 2002 [2013]: 904). Pero por su parte Guelbenzu siempre habla de juez Mariana de Marco. La investigación podría empezar con la reflexión que María Milagros Rivera (1994) realiza sobre la importancia que tiene el nombrar en femenino.

En Castellón hay cierta tradición de novela negra. Desde luego, la afición al género es innegable, recordemos, entre otras actividades en torno a este género, el festival Castellón Negro, y tampoco se puede negar el gran número de escritoras y escritores amateurs de la provincia que sitúan sus novelas negras en este entorno y que están protagonizadas por personajes femeninos, como Acuarela, de Bárbara Sáez Vidal (2014), o Larga tormenta de otoño, de José Manuel González de la Cuesta (2011), por mencionar únicamente algún ejemplo. A este corpus de autoras y autores locales se les podrían aplicar las variables de análisis mencionadas antes y realizar un trabajo de literatura comparada.

El cine y la televisión mantienen tradicionalmente una relación muy fructífera. Como línea de investigación futura y siguiendo ese planteamiento se puede ahondar en el cambio que las mujeres han tenido en las series de policías (procedimentales) desde ese momento. ¿Cuántas mujeres eran las investigadoras centrales en las series antes de la entrada en el nuevo siglo? ¿Cuántas hay en los últimos quince años? ¿España sigue el ejemplo de otros países? En las series estadounidenses sí se produce este cambio: The Closer (2005-2012), Bones (20052017), Rizzoli \& Isles (2010-2016), Major Crimes (2012- ), entre otras. 


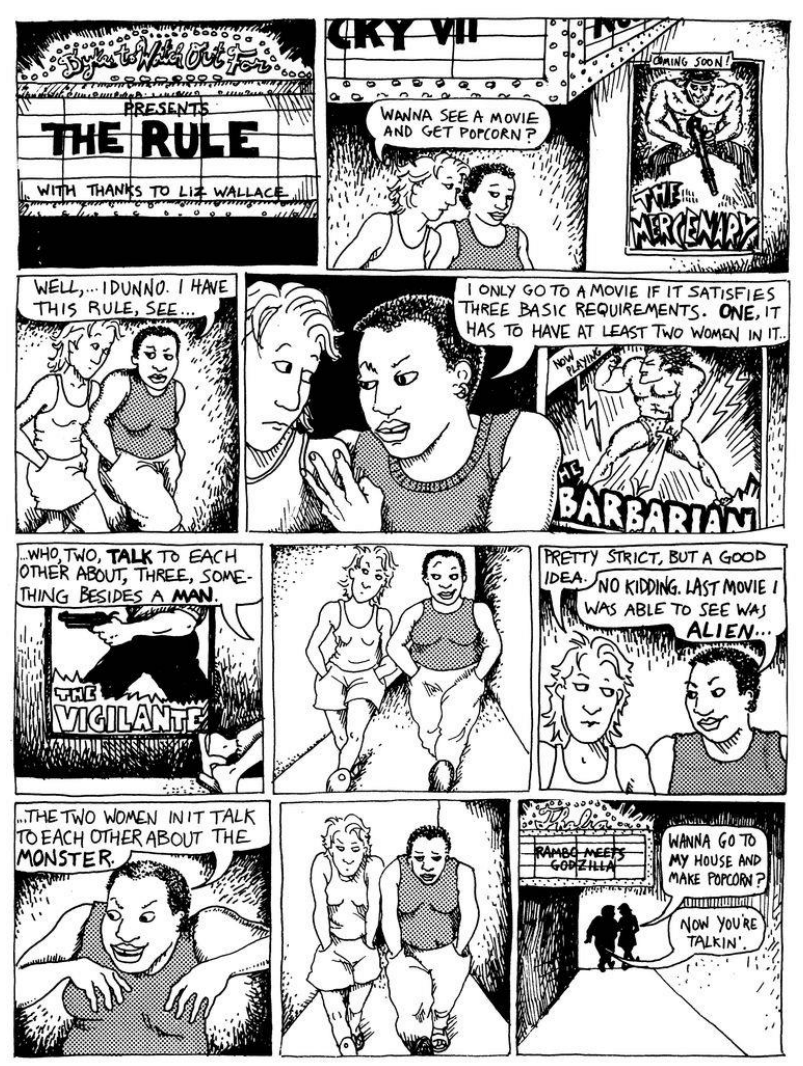

Alison Bechdel (1985) «Dykes to Watch Out». The Rule

Finalmente, planteamos una línea de investigación diferente a las anteriores. Consideramos que podría ser interesante «aplicar» un test de Bechdel $^{144}$ a las novelas para establecer si los criterios utilizados son machistas o igualitarios. Este test se podría desarrollar a partir del ya existente para el mundo cinematográfico, adaptándolo tras una revisión crítica. Sin embargo, debido a la

\footnotetext{
${ }^{144}$ Alison Bechdel dibujó en 1985 la tira «Dykes to Watch Out For» en el cómic The Rule. Uno de los personajes (femenino) comenta con el otro protagonista de la tira (también femenino) que no iría al cine a ver una película que no cumpliera las siguientes condiciones: en la película deben salir, al menos, dos mujeres; estas mujeres deben de hablar entre ellas y el tema de la conversación no debe hacer referencia a un personaje masculino. Esta conversación sirve como base para la creación del «Test de Bechdel», un sistema para medir el sexismo de los productos audiovisuales. Aunque nace sin pretensiones científicas, sólo como elemento para reflexionar, es un instrumento que permite establecer la representatividad de las mujeres en un producto audiovisual concreto. Posteriormente Anita Sarkeesian (2010) propone añadir una cuarta condición: que esta conversación entre mujeres debe de durar, al menos, sesenta segundos (el motivo, que un diálogo de esa extensión puede resultar relevante para el argumento). Sarkeesian y otras autoras, como la periodista Walt Hickey o el equipo de FiveThirtyEight, han contribuido desde 1990 hasta la actualidad con sus análisis de más de 7000 películas cuyos resultados se pueden consultar en la página: http:// bechdeltest.com/ (Fecha de consulta: 3 de marzo de 2017).
} 
complejidad de cualquiera de los relatos con tramas y subtramas, se nos antoja una tarea complicada, sobre todo porque no debería circunscribirse únicamente a la novela negra, sino que tendría que ser aplicable a otros géneros.

En definitiva, el género negro es tan amplio y está tan vivo que crece día a día. Esto hace que se nos presenten nuevas preguntas según avanzamos en la investigación, lo que nos abre nuevas posibilidades para continuar nuestro trabajo en un futuro, respondiendo a algunas de estas cuestiones, aunque se nos antoja una tarea titánica la que todavía nos queda por delante.

El elemento positivo es que disfrutamos acompañando a todas estas investigadoras e investigadores en sus casos, y seguir haciéndolo será un placer. 


\begin{tabular}{|c|}
\hline \multicolumn{1}{|c|}{ BIBLIOGRAFÍA } \\
Bibliografía primaria \\
Corpus \\
Otras obras literarias citadas \\
Bibliografía secundaria
\end{tabular}





\section{Bibliografía}

\section{Bibliografía primaria}

Corpus de la tesis

Giménez BARTLetT, Alicia (2013) Serie Petra Delicado, Barcelona: Destino. (ebook)

Libros incluidos en el pack Serie Petra Delicado:

Giménez BARTlETt, Alicia (1996) Ritos de muerte, Barcelona: Destino, 2013. (ebook)

Giménez Bartlett, Alicia (1997) Días de perros, Barcelona: Destino, 2013. (ebook)

Giménez BARTlett, Alicia (1999) Mensajeros de la oscuridad, Barcelona: Destino, 2013. (ebook)

GiménEz BARTLETT, Alicia (2000) Muertos de papel, Barcelona: Destino, 2013. (ebook)

Giménez BARTlETt, Alicia (2002) Serpientes en el paraíso, Barcelona: Destino, 2013. (ebook)

GIMÉNEZ BARTLETT, Alicia (2004) Un barco cargado de arroz, Barcelona: Destino, 2013. (ebook)

Giménez BARTLetT, Alicia (2007) Nido vacío, Barcelona: Destino, 2013. (ebook)

GimÉnEz BARTLETT, Alicia (2009) El silencio de los claustros, Barcelona: Destino, 2013. (ebook)

GimÉnez BARTLETT, Alicia (2013) Nadie quiere saber, Barcelona: Destino. (ebook) 
Alicia Giménez Bartlett y Mercedes Castro

Giménez BARTLETt, Alicia (2015) Crímenes que no olvidaré, Barcelona: Destino. (ebook)

CASTRO, Mercedes (2008) Y punto, Madrid: Alfaguara, 2010. (ebook)

CASTRO, Mercedes (2010) Mantis, Madrid: Alfaguara.

Otras obras literarias citadas

BASSAS, Carlos (2016) Mal trago, Barcelona: Al revés.

BoRDA, Itxaro (1994) Bakean ützi arte (Hasta que nos dejen en paz), Zarautz: Susa.

BordA, Itxaro (2012) Boga, boga, Zarautz: Susa.

CARRÁ, JuAn (2016) Lloran mientras mueren, Buenos Aires: Editoral Versales.

Снiсот, Marco (2016) El asesinato de Sócrates, Barcelona: Planeta.

Du MAURIER, Daphne (1938) Rebecca, Londres: Victor Gollancz Ltd.

García SÁEnz De Urturi, Eva (2016) El silencio de la ciudad blanca, Barcelona: Planeta.

GARCía SÁENZ DE URTURI, Eva (2017) Los ritos del agua, Barcelona: Planeta.

GimÉnEz BARTLETT, Alicia (1997) La habitación ajena, Barcelona: Belacqua de Ediciones y Publicaciones.

GonZÁlez DE LA CuestA, José Manuel (2011) Larga tormenta de otoño, Castellón: autoeditado.

GuELBEnZU, José María (2001) No acosen al asesino, Madrid: Alfaguara. (ebook)

GuELBEnZU, José María (2008) Un asesinato piadoso, Madrid: Alfaguara.

Kirino, Natsuo (1997) Out, Barcelona: Emecé (traducción de Albert Nolla Cabellos), 2008. 
Konate, Moussa (2009) La malédiction du Lamantin, Paris: Points.

Montero, Rosa (1997) La hija del caníbal, Madrid: Espasa.

Moreno, Eloy (2011) El bolígrafo de gel verde, Castellón: autoeditado.

NDINE, Abasse (2000 [2007]) Ramata, Barcelona: Roca editorial (traducción Dolors Gallart Iglesias).

OLIVER, Mํㅡㄹ Antonia (1985) Estudi en lila, Barcelona: La Magrana.

OrTiz, Lourdes (1979) Picadura mortal, Madrid: Sedmay Ediciones.

PGARCÍA (1982) Flower al aparato, Barcelona: Planeta.

RARo Rosario (2017) La huella de una carta, Barcelona: Planeta.

RARo, Rosario (2015) Volver a Canfranc, Barcelona: Planeta.

REDondo, Dolores (2013a) El guardián invisible, Barcelona: Destino.

REDondo, Dolores (2013b) Legado en los huesos, Barcelona: Destino.

REDondo, Dolores (2014) Ofrenda a la tormenta, Barcelona: Destino.

REDONDO, Dolores (2016) Todo esto te daré, Barcelona: Planeta.

SÁEz VIDAL, Bárbara (2014) Acuarela, Castellón: ACEN.

SANZ, Marta (2010) Black, Black, Black, Barcelona: Anagrama.

SANZ, Marta (2012a) Un buen detective no se casa jamás, Barcelona: Anagrama.

SiLVA, Lorenzo (1998) El lejano país de los estanques, Barcelona: Destino.

SILVA, Lorenzo (2000) El alquimista impaciente, Barcelona: Destino.

SILVA, Lorenzo (2012) La marca del meridiano, Barcelona: Planeta.

SiLVA, Lorenzo (2016) Donde los escorpiones, Barcelona: Destino. 


\section{Bibliografía secundaria}

AinAS, Txema (20 de mayo de 2016) «La novela negra en lengua vasca». En Solo novela negra. Disponible en: https://solonovelanegra.com/la-novela-negraen-lengua-vasca/.Fecha de consulta: 25 de mayo de 2017.

Alberola Crespo, Nieves (2012a) «Una definición polémica: la identidad femenina». En Rosalía Torrent Esclapés y Sonia Reverter Bañón (eds.), Variaciones sobre género, Castelló de la Plana: Acen, pp. 43-54.

Alberola Crespo, Nieves (2012b) «Homes and Kitchens. Rethinking on the Works of Susan Glaspell, Tennesse Williams and Lynn Nottage». En Mauricio D. Aguilera Linde, María José de la Torre Moreno, Laura Torres Zúñiga (ed.), Into Another's Skin: Selected Essays in Honour of Maria Luisa Dañobeitia, Granada: Universidad de Granada, pp. 201-209.

Almela, Margarita (2014) «Reflexiones sobre los estereotipos de maldad y bondad femeninas». En Malas, Madrid: Universidad Nacional de Educación a Distancia (UNED), pp. 58-106. (ebook)

Amorós, Celia (1997) Tiempo de feminismo. Sobre feminismo, proyecto ilustrado y postmodernidad, Madrid: Cátedra, 2000.

ApARICIO LlanAS, Ma Pilar y Gimeno, Isabel (1996) Literatura menor del siglo XIX, Vol. I. Ideas literarias. Temas recurrentes, Barcelona: Anthropos.

ARITZETA, Margarita (2014) «Jaume Fuster, la ficció sense fronteres». En Ítaca. Revista de Filologia. Alacant: Universitat d'Alacant, pp. 161-178. Disponible en: $\quad$ http://rua.ua.es/dspace/bitstream/10045/43540/1/Itaca_05.pdf. Fecha de consulta: 20 de mayo de 2017.

AuberT, Paul (2001) «La novela en España en los siglos XIX y XX. Historia, sociedad, búsqueda identitaria». En Paul Aubert, La novela en España: siglos XIX-XX, Madrid: Casa de Velázquez, pp. 5-17.

BADINTER, Elizabeth (1981) ¿Existe el amor maternal? Historia del amor maternal. Siglos XVIII al XX, Barcelona: Paidós (traducción de Marta Vassallo). 
BADOS CIRIA, Concepción (2010) «Feminización de la novela policiaca: alternativas para un cambio sociológico». En Mercedes González de Sande (ed.), La imagen de la mujer y su proyección en la literatura, la sociedad y la historia, Sevilla: ArCiBel Ediciones, pp. 27-48.

BALCELLS, Salvador (2014) «Rafael Tasis, els fonaments d'un gènere». En Ítaca. Revista de Filologia. Alacant: Universitat d'Alacant, pp. 215-230. Disponible en: http://rua.ua.es/dspace/bitstream/10045/43540/1/Itaca_05.pdf. Fecha de consulta: 20 de mayo de 2017.

BALiBreA, Mari Paz (2002) «La novela negra en la transición española como fenómeno cultural: una interpretación». En Iberoamericana (2001- ), vol. 2, no 7, pp. 111-118. Disponible en: http://www.jstor.org/stable/41672977. Fecha de consulta: 21 de marzo de 2017.

BALLó, JoRdi y PÉREZ, XAVIER (2005) Yo ya he estado aquí: ficciones de la repetición, Barcelona: Anagrama.

BALOGH, Anna María (2011) «La femme fatale en el noir». En Javier Sánchez Zapatero y Álex Martín Escribá (eds.), Género negro para el siglo XXI. Nuevas tendencias y nueva voces, Barcelona: Laertes, pp. 247-258.

BEAuvorr, Simone de (1949) El segundo sexo, Madrid: Cátedra (traducción de Alicia Martorell), 2011.

BENET, Vicente J. (2006) «Madres, vampiresas y mujeres caídas: imaginario femenino del primer cine de gangsters». En Dossiers Feministes. Mujeres y Universo Policial: Los cuerpos del delito, n. 9, Castellón de la Plana: Seminari d’Investigació Feminista de la Universitat Jaume I, pp. 105-123.

Berger, John (1974) Modo de ver, Barcelona: Gustavo Gili (traducción de Justo González Beramendi), 2000.

Bergman, Krestin (2014) «The Captivating Chill: Why Readers Desire Nordic Noir». En Scandinavian-Canadian Studies/ Études Scandinaves au Canada, vol. 2., Victoria: University of Victoria, pp. 80-89. Disponible en: 
http://scancan.net/pdf/bergman_1_22.pdf. Fecha de consulta: 25 de mayo de 2017.

BERLIÈRE, Jean-Marc (2011) «La invención de la policía "republicana" en la Francia de la Tercera República». En Diego Galeano y Gregorio Kaminsky (coord.), Mirada (de) uniformes. Historia y crítica de la razón policial, Buenos Aires: Teseo. Universidad Nacional de Rio Negro, pp. 49-68.

Blanco, Alda (1998) «Escritoras, feminidad y escritura en la España de medio siglo». En Iris M. Zavala (coord.), Breve historia de la literatura española (en lengua castellana). V. Literatura escrita por mujeres. Desde el siglo XIX hasta la actualidad, Barcelona: Anthropos, pp. 9-38.

BIEder, Maryellen (1998) «Emilia Pardo Bazán y la emergencia del discurso feminista». En Iris M. Zavala (coord.), Breve historia de la literatura española (en lengua castellana). V. Literatura escrita por mujeres. Desde el siglo XIX hasta la actualidad, Barcelona: Anthropos, pp. 75-110.

Biblioteca NACiONAL (s.f.) Web oficial. Disponible en: http://www.bne.es/es/Micrositios/Guias/novela_policiaca/seleccion_novel as/nn_japonesa/. Fecha de consulta: 20 de marzo de 2017.

«BOE» núm. 46, de 23 de febrero de 1988, Real Decreto-Ley 1-1988, de 22 de febrero, por el que se regula la incorporación de la mujer a las Fuerzas Armadas, páginas 5672 a 5672 (1 pág.).

«BOE» núm. 313, de 29 de diciembre de 2004, Ley Orgánica 1/2004, de 28 de diciembre, de Medidas de Protección Integral contra la Violencia de Género, páginas 42166 a 42197 (32 págs.).

Bollmann, Stefan (2005) Las mujeres que leen son peligrosas, Madrid: Maeva (traducción de Ana Košutič).

BonatTo, Adriana (2012) «Los registros de la violencia en La hija del Caníbal de Rosa Montero». En Revista Crítica Cultural, vol. 7, nº 1, pp. 67-81. Disponible en: 
http://portaldeperiodicos.unisul.br/index.php/Critica_Cultural/article/vie w/950/pdf_40. Fecha de consulta: 20 de marzo de 2017.

Bonino, Luis (2004) «Los micromachismos». En La Cibeles, vol. 2, noviembre de 2004. Disponible

en: http://www.luisbonino.com/pdf/Los\%20Micromachismos\%202004.pdf. Fecha de consulta: 4 de enero de 2017.

Bordoy, Alejandro Casadesús (2011) Negra i mallorquina: origens i evolució de la novel·la policiaca a Mallorca, vol. 442, Barcelona: L'Abadía de Monserrat.

BORNAY, Erika (1990) Las hijas de Lilith, Madrid: Cátedra.

Brownmiller, Susan (1975) Against our Will: Men, Women and Rape, New York: Open Road Integrated Media, 2013. (ebook)

BuTlER, Judith (1990) El género en disputa. El feminismo y la subversión de la identidad, Barcelona: Paidós (traducción de M.르 Antonia Muñoz), 2007.

CABAlLERo, Marta (17 de octubre de 2016) «Ellas tienen la palabra». Disponible en: http://www.elmundo.es/cultura/2016/10/17/5804469ae5fdeafb7e8b457 1.html. Fecha de consulta: 20 de marzo de 2017.

CABAllero Guiral, Juncal (2012) «¿Privado? ¿Público? La (des)construcción de una dicotomía patriarcal». En Rosalía Torrent Esclapés y Sonia Reverter Bañón (eds.), Variaciones sobre género, Castelló de la Plana: Acen, pp. 67-75.

CAmarasa, Paco (2016) Sangre en los estantes, Barcelona: Destino.

Canalda, José Luis y Cantero URibe-Echevarría, Igor (2002) «Las lecciones de ciencia ficción popular en España (1950-1990)». En La ficción española, Madrid: Robel, pp. 67-93.

CANALES, Esteban (1999) La Inglaterra victoriana, Madrid: Akal, 2008.

CARABÍ, Àngels (2000) «Construyendo nuevas masculinidades. Una introducción». En Marta Segarra y Àngels Carabí (eds.), Nueves Masculinidades, Barcelona: Icaria, pp. 15-27. 
CARbonell I CoRTÉs, Ovidi (1997) Traducir al otro: traducción, exotismo, poscoloniamismo, Cuenca: Universidad de Castilla-La Mancha.

Castellanos, Rosario (1950) Sobre cultura femenina, México: Fondo de Cultura Económica, 2005.

CATolRA, Carla Figueiras (2014) «La novela negra desde África, un ejemplo: el conocimiento del otro en "La malédiction du Lamantin" de Moussa Konaté». En Àlex Martín Escribà y Javier Sánchez Zapatero (eds.), La (re)invención del género negro, La Coruña: Andavira Editora, pp. 301-308.

Centro Mujeres y literatura. GÉnero, seXualidades, crítica de la cultura (s.f.) Web oficial. Disponible en: http://www.ub.edu/cdona/es/que-es. Fecha consulta 17 de mayo de 2017.

CERQueIro, Diana (2010): «Sobre la novela policíaca». En: Ángulo Recto. Revista de estudios sobre la ciudad como espacio plural, vol. 2, núm. 1. Disponible en: http://www.ucm.es/info/angulo/volumen/Volumen02-1/varia01.htm.

Fecha de consulta: 30 de diciembre de 2016.

Cervera Torres, Rafael (2012) Alaska y otras historias de la movida, Barcelona: Plaza y Janés. (ebook)

CHoI, Myung N. (2012) La mujer en la novela policial: evolución de la protagonista femenina en cinco autoras hispanas, Bloomington, IN (EEUU): Palibrio.

Collins, Phillip (1962) Dickens and Crime, London: MacMillan, 1994.

Colmeiro, José F. (1994) Novela policiaca española: teoría e historia crítica, Barcelona: Anthropos.

Coma, Javier (1980) La novela negra: historia de la aplicación del realismo crítico a la novela policíaca norteamericana, Barcelona: Ediciones 2001.

Corroto, Paula (10 de abril de 2010) «Mercedes Castro explora la "tragedia" de la maternidad en "Mantis"». En Público. Disponible en: http://www.publico.es/culturas/mercedes-castro-explora-tragediamaternidad.html. Fecha de consulta: 10 de diciembre de 2016. 
CoRroto, Paula (15 de abril de 2014) «Novela negra: entre lo sórdido y lo poético». En eldiario.es.

Disponible

en: http://www.eldiario.es/cultura/libros/Novela-negra-japonesa-sordidopoetico_0_313919557.html. Fecha de consulta: 25 de mayo de 2017.

Creed, Barbara (1993) The Monstruous-Feminine. Film, Feminism, Psychoanalysis, New York: Routledge, 2012.DorCA, Toni (1997) «Joven narrativa en la España de los noventa: La generación X». En Revista de Estudios Hispánicos, 31. Vol.2, pp. 309-324. Disponible en: https://www.academia.edu/27891130/Joven_narrativa_en_la_Espa\%C3\%B 1a_de_los_noventa_la_generaci\%C3\%B3n_X.pdf. Fecha de consulta: 30 de mayo de 2017.

DovaL, Gregorio (2009) Breve historia de la conquista del Oeste, Madrid: Ediciones Nowtilus.

EMSLEY, Clive (2011) «Los modelos de policía en el siglo XIX». En Diego Galeano y Gregorio Kaminsky (coord.), Mirada (de) uniformes. Historia y crítica de la razón policial, Buenos Aires: Teseo. Universidad Nacional de Rio Negro, pp. 21-48.

EquiPo E.P. (1977) Nuevo Testamento, Madrid: Ediciones Paulinas.

Europa Press (16 de abril de 2010) «Mercedes Castro se burla en su novela, 'Mantis', de los estereotipos profesionales a través de una 'femme fatale'». En 20 Minutos. Disponible http://www.20minutos.es/noticia/679909/0/. Fecha de consulta: 8 de diciembre de 2016.

EuSKomedia. Kultura Topagune. http://www.euskomedia.org/. Fecha de consulta: 8 de diciembre de 2016.

FERNÁNDEZ, Rebeca (25 de abril de 2011) «En España no se hacen series de personaje». $\quad$ En Público. http://www.publico.es/actualidad/espana-no-series-personaje.html. Fecha de consulta: 17 de mayo de 2017. 
FERnÁNDEZ IgLESIAS, Arantzazu (2014) «Y Amaia Expeldoi te abrirá los ojos: una detective rural contra el sistema». En Malas, Madrid: Universidad Nacional de Educación a Distancia (UNED), pp. 221-238. (ebook)

FILADón (13 de abril de 2010) «Me puede el afán de contar historias». En Diario de León. Disponible en: http://www.diariodeleon.es/noticias/filandon/mepuede-afan-contar-historias_534081.html. Fecha de consulta: 20 de mayo de 2017.

FuEntes Herbón, Isabel-Argentina (2001) Del Naturalismo al Decadentismo, pasando por la mujer fatal. Imagen femenina y literatura española en los inicios de la modernidad, Valencia: Universidad de Valencia. (tesis doctoral)

Galindo, Juan Carlos (1 de abril de 2016) «El machismo como enfermedad de la novela negra española». En elmundo.es. Disponible en: http://cultura.elpais.com/cultura/2016/04/01/elemental/1459481832_14 5948.html. Fecha de consulta: 20 de marzo de 2017.

GARCíA, Luis (31 de marzo de 2016) «Mercedes Castro: "Soy una gran consumidora de cine, de cómic, de música, de series de televisión de calidad». En Literaturas.com. Madrid: LcL Disponible http://www.literaturas.com/v010/sec0803/nuestro_novel/nuestronovel.h tm. Fecha de consulta: 23 de mayo de 2017.

GELI, Carles (31 de enero de 2014) «'Femicrime', una tendencia en alza en la novela negra policiaca». En El País. Disponible en: http://cultura.elpais.com/cultura/2014/01/30/actualidad/1391112276_8 86956.html. Fecha de consulta: 30 de marzo de 2017.

GimÉnEz BARTLETT, Alicia (s.f.) Web oficial. Disponible en: http://www.aliciagimenezbartlett.es/es/Alicia_Gimenez_Bartlett/. Fecha de consulta: 29 de diciembre de 2016.

Gilbert, Sandra M. y Gubar, Susan (1979) Las locas del desván. La escritora y la imaginación literaria del siglo XIX, Madrid: Cátedra (traducción de Carmen Martínez Gimeno), 1984. 
GoRDo, Alberto (22 de septiembre de 2014) «José María Guelbenzu: "La novela negra está metida en un berenjenal de psicopatía y gore». En El Cultural. Disponible en: http://www.elcultural.com/noticias/buenos-dias/JoseMaria-Guelbenzu/6808. Fecha de consulta: 16 de mayo de 2017.GodSLAND, Shelley (2011) Killing Carmens: Women's Crime Fiction from Spain, Cardiff: University of Wales Press.

GonZÁLEZ, Eric (22 de agosto de 2016) «'El sueño eterno’: el despertar de un género literario». En elmundo.es. Disponible http://www.elmundo.es/cultura/2016/08/22/57b724e546163fd5758b46 58.html. Fecha de consulta: 19 de diciembre de 2016.

GonZÁLEZ-ARIZA, Fernando (2004) Literatura y sociedad: El premio Planeta, Madrid; Universidad Complutense de Madrid. (tesis doctoral)

GonZÁlEZ DE LA AlEJA BARBERÁN, Manuel (2014) «El caso del reactivo precipitado por la hemoglobina: la novela policiaca y sus (des)encuentros con la ciencia». En Revista Signa. Revista de la Asociación Española de Semiótica, 23, Madrid: Universidad Nacional de Educación a Distancia (UNED), pp. 175-201.

GonZÁLEZ LEDESMA, Francisco (1987) «La prehistoria de la novela negra». En Cuadernos del Norte, 41, marzo-abril, Valencia: Faximil Edicions Digitals, pp. 10-14. Disponible en: http://gonzalezledesma.blogspot.com.es/1987/. Fecha de consulta: 12 de mayo de 2017.

GonZÁLEZ LóPEZ, Jesús Ángel (2004) La narrativa popular de Dashiell Hammett, 'Pulps', cine y comics, Valencia: Biblioteca Javier Coy d'Estudis NordAmericans, Universitat de València.

GoÑI, Ana (10 de marzo de 2013) «Alicia Giménez Bartlett habla con la auténtica Petra Delicado». En El confidencial. Disponible en: http://www.elconfidencial.com/cultura/2013-03-10/alicia-gimenezbartlett-habla-con-la-autentica-petra-delicado_736044/. Fecha de consulta: 17 de mayo de 2017.

GrimaL, Pierre (1951) Diccionario de mitología griega y romana, Barcelona: Ediciones Paidós, pp. 89-90 (traducción de Francisco Payarols), 1981. 
Grosman, Celia, P., Meterman, Silvia y Adamo, María T. (1989): Violencia de la familia: la relación de la pareja, aspectos sociales, psicológicos y jurídicos, Buenos Aires: Universidad de los Andes.

Guillén, Francesc (2015) Modelos de Policía y Seguridad, Bellaterra: Universitat Autònoma de Barcelona. (tesis doctoral) Disponible en: http:// www.tdx.cat/bitstream/10803/291813/1/fgl1de1.pdf. Fecha de consulta: 2 de mayo de 2017.GoldSLAnd, Shelley (2002) «Maria Antònia Oliver: la reescritura femenina/feminista de la novela negra». En Bulletin of Hispanic Studies, vol. 79, no 3, pp. 345-360. Disponible en: http://dx.doi.org/10.3828/bhs.79.3.7. Fecha de consulta: 21 de marzo de 2017.

GuTIÉRREZ, José Ismael (2014) «Las masculinidades en la narrativa antidetectivesca de Marta Sanz: el detective gay Artuzo Zarco». En Letras Femeninas, Volumen 40, no 2, Denver: University of Colorado, pp. 109-127. Disponible en:

https://www.academia.edu/12386719/_Las_masculinidades_alternativas_en_la_narra tiva_antidetectivesca_de_Marta_Sanz_el_detective_gay_Arturo_Zarco._Letras_Femen inas_40.2_2014_109-127. Fecha de consulta: 12 de junio de 2017.

GuTiÉRREZ, María Alicia (comp.) (2013) Voces polifónicas. Itinerarios de los géneros y las sexualidades, Buenos Aires: Ediciones Godot.

GuElbenzu, José María (s.f.) Web oficial. Disponible en: http://www.jmguelbenzu.com/. Fecha de consulta: 12 de mayo de 2017.

Hamilton, Cynthia S. (1987) Western and Hard-Boiled Detective Fiction in America: From High Noon to Midnight, London: MacMillan.

HART, Patricia (1987) The Spanish Sleuth: The Detective in Spanish Fiction, Rutherford, Madison and Teaneck Fairleigh Dickinson University Press, London and Toronto: Associated University Presses.

HERAS, Marcos (19 de octubre de 2010) «La "novela negra" en África se llama solamente literatura». En Ritmos21. Millennial Culture Information. Disponible en: http://www.ritmos21.com/1564/la-novela-negra-en-africa- 
se-llama-solamente-literatura.html. Fecha de consulta: 20 de marzo de 2017.

HoBSBAWN, Eric J. (1971) En torno a los orígenes de la revolución industrial, Madrid: Siglo XXI (traducción de Ofelia Castillo), 2003.

HoRSLEY, Lee (2005) Twentieth-century Crime Fiction, Oxford: Oxford University Press.

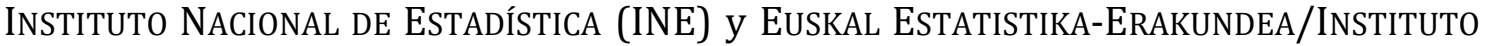
VASCO DE EsTADÍSTICA (EUSTAT) (14 de diciembre de 2005) «Encuesta sobre las personas sin hogar (EPSH 2005)». Madrid: Instituto Nacional de Estadística. Disponible en: http://www.ine.es/prensa/np398.pdf. Fecha de consulta: 6 de junio de 2017.

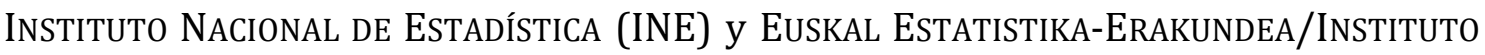
VASco DE Estadística (EUSTAT) (21 de diciembre de 2012) «Encuesta a las personas sin hogar Avance de resultados. Año 2012». Madrid: Instituto Nacional de Estadística. Disponible http://www.ine.es/prensa/np761.pdf. Fecha de consulta: 6 de junio de 2017.

InTXAUSTI, Aurora (24 de enero de 2013) «La mayoría de los escritores nórdicos son nefastos». En El País. Disponible en: http://cultura.elpais.com/cultura/2013/01/24/elemental/1359016326_13 5901.html. Fecha de consulta: 30 de marzo de 2017.

JAMES, P. D. (2009) Todo lo que sé sobre novela negra, Barcelona: Ediciones B (traducción de María Alonso), 2010. (ebook)

Juliano, Dolores (1998) Las que saben. Subculturas de mujeres, Madrid: Horas y Horas.

KINGERY, Sandra (2013) «Policing Social Injustice: Alicia Gimenez Bartlett's Petra Delicado Series». En Estrella Cibeiro y Francisca López (eds.), Global Issues in Contemporary Hispanic Women's Writing. Shaping Gender, the Environment, and Politics, New York: Routledge. 
KotTAK, Conrad Phillip (1971) Antropología: una exploración de la diversidad humana con temas de cultura hispana, Madrid; McGraw-Hill, 1994 (traducción José C. Lisón Arcal).

LAGARDE, Marcela (1993) Los cautiverios de las mujeres: madresposas, monjas, putas, presas y locas, México: Universidad Nacional Autónoma de México (UNAM), 2006.

LARIO, Ores (6 de noviembre de 2015) «Alicia Giménez Bartlett, Premio Planeta: "Recurrir a la prostitución masculina es como un ejercicio de poder"». En Cambio16. Disponible en: http://www.cambio16.com/actualidad/aliciagimenez-bartlett-premio-planeta/. Fecha de consulta: 21 de mayo de 2017.Lissorgues, Yvan, (1991) «Algunos aspectos de la renovación de la novela española desde 1975». En La renovation du roman espagnol depuis 1975: actes du colloque des 13 et 14 février 1991, avec un texte inédit de Manuel Vázquez Montalbán, La novela española entre el posfranquismo y el posmodernismo, Toulouse: Presses Univ. du Mirail, pp. 27-38.

LISSOURGES, Yvan (1992) «La novela detectivesca española actual: un posibilismo realista». En Actas de la Asociación Inernacional de Hispanistas, California: Universidad de California, pp. 173-182. Disponible en: http://cvc.cervantes.es/literatura/aih/pdf/11/aih_11_4_022.pdf. Fecha de consulta: 8 de marzo de 2017.

LOSADA SOLER, Elena (2015) «Matar con un lápiz. La novela criminal escrita por mujeres». En Lectora, 21, Barcelona: Universitat de Barcelona, pp. 9-14. Disponible en: http://revistes.ub.edu/index.php/lectora/issue/view/1262. Fecha de consulta: 20 de mayo de 2017.

LÓPEZ MARTínEZ, Marina (2006) «Historia de la novela policíaca. Introducción al género en femenino». En Dossiers Feministes. Mujeres y Universo Policial: Los cuerpos del delito, n. 9, Castellón de la Plana: Seminari d’Investigació Feminista de la Universitat Jaume I, pp. 11-31.

MACKLIN, John (2006) «Conformismo y disidencia: realismo, género y novela negra en España». En Moenia. Revista Lucense de Lingüística e Literatura, Santiago 
de Compostela: Universidade de Santiago de Compostela, pp. 425-504. Disponible en: https://minerva.usc.es/xmlui/handle/10347/5724. Fecha de consulta: 10 de mayo de 2017.

MALGORZATA, Janerk (2010) La novela policiaca española (1975-2005), Vigo: Editorial Academia del Hispanismo.

MAÑA, José Ángel (s.f.) Web autorizada. Disponible en: http://www.joseangelmanas.com/novelas.html. Fecha de consulta: 6 de junio de 2017.

Martín Alegre, Sara (2002) «El caso de Petra Delicado: La mujer policía en las novelas de Alicia Giménez Bartlett». En Carmen Riera, Meri Torras e Isabel Clúa (eds.), Perversas y divinas. La representación de la mujer en las literaturas hispánicas: el fin de siglo y/o el fin de milenio actual, Bellaterra: Universitat Autònoma de Barcelona, pp. 415-421.

Martín Cerezo, Iván (2006) Poética del relator policiaco (de Edgar Allan Poe a Raymond Chandler), Murcia: Universidad de Murcia.

MemBRA, Javier (20 de octubre de 2015) «Giménez Bartlett, la mujer en la novela negra». Disponible en: http://www.elmundo.es/cultura/2015/10/22/562892d1e2704e86178b45 fa.html. Fecha de consulta: 20 de marzo de 2017.

MiAMPIKA, Laundry-Wilfrid (18 de septiembre de 2009) «Negro sobre negro: un nuevo género policiaco refleja la violencia de África». En larazon.es. Disponible en: http://www.larazon.es/historico/negro-sobre-negro-unnuevo-genero-policiaco-refleja-la-violencia-de-africa-

ULLA_RAZON_163325. Fecha de consulta: 20 de marzo de 2017.

Ministerio de EduCACión, Cultura y Deporte y ObSERVATORio DE LA LECTURA Y EL Libro (2015) El sector del libro en España (2013-2015), Madrid: Ministerio de Educación, Cultura y Deporte y Observatorio de la lectura y el libro. Disponible en: http://www.mecd.gob.es/dms/mecd/cultura-mecd/areascultura/libro/mc/observatoriolect/redirige/estudios-e- 
informes/elaborados-por-el-observatoriolect/sector-libro-

abril2015/sector-libro-abril2015.pdf. Fecha de consulta: 1 de abril de 2017.

Molinaro, Nina L. (2016) Policing Gender and Alicia Giménez Bartlett's Crime Fiction, New York: Routlege.

Monlau, Pedro Felipe (1856) Diccionario etimológico de la lengua castellana, Madrid: Imprenta y estereotipia de M. Rivadeneyra.

Montalbán Huertas, Inmaculada (16 de diciembre de 2007) «Desde Ana Orantes». Disponible

en: http://elpais.com/diario/2007/12/16/andalucia/1197760924_850215.ht ml. Fecha de consulta: 24 de abril de 2017.

Montiel Álvarez, Teresa (2016) «La fotografía policial en el siglo XIX. El sistema Bertillon». En ArtyHum. Revista de Artes y Humanides. La fotografía como herramienta científica, no 21, Vigo: ArtyHum, pp. 148-159. Disponible en: https://www.artyhum.com/descargas/PDF/ArtyHum\%20n\%C2\%BA\%202 1.pdf. Fecha de consulta: 5 de mayo de 2017.

MoRet, Xavier (4 d julio de 1995) «El tímido resurgir de la novela negra. Los autores españoles siguen ejerciendo de francotiradores». En El País. Disponible: http://elpais.com/diario/1995/07/04/cultura/804808805_850215.html. Fecha de consulta: 15 de mayo de 2017.

Mujeres y Novela CRiminal en EsPaÑa (1975-2010) MUNCE (s.f.) Web oficial. Disponible en: http://www.ub.edu/munce/. Fecha de consulta: 17 de mayo de 2017.

NARCEJAC, Thomas (1986) Una máquina de leer: la novela policiaca, México: Fondo de Cultura Económica (traducción de Jorge Ferreiro).

Olmos SÁNCHEZ, Isabel (2013) «Imperialismo y colonización (1885-1914)». En Paloma García Picazo (coord.), La sociedad internacional en el cambio de siglo (1885-1919), Madrid: UNED, pp. 51-98. 
PARElla RuBio, Sònia (2003) Mujeres, inmigrantes y trabajadora: la triple discriminación, Barcelona: Anthropos.

PARra Membrives, Eva (2013) «Crímenes con denominación de origen. Glocalización en la novela policiaca nórdica femenina». En Revista Signa. Revista de la Asociación Española de Semiótica, 22, Madrid: Universidad Nacional de Educación a Distancia (UNED), pp. 549-567. Disponible en: http://revistas.uned.es/index.php/signa/article/view/6366/6099. Fecha de consulta: 19 de marzo 2017.

Pascual Soler, Nieves (2013) «Comiendo del mismo plato: mecanismos de exotización en la obra de Donna Leon». En Nieves Alberola (ed.), Dossiers Feministes. La cultura de las cocinas, n. 17, Castellón de la Plana: Instituto Universitario de Estudios Feministas y de Género «Purificación Escribano» de la Universitat Jaume I, pp. 111-127.

PiÑol, Rosa María (27 de julio de 1991) «Mi novela para 'La Vanguardia' describe con realismo el mundo de las sectas». En La Vanguardia, p. 34. Disponible en: http://hemeroteca.lavanguardia.com/preview/1986/04/08/pagina34/33485509/pdf.html. Fecha de consulta: 25 de mayo de 2017.

Pizarro Prada, María (2013) «De policías, detectives y crímenes: la actualidad de la novela policiaca». En Revista Iberoamericana, 51, Pittsburgh: University of Pittsburgh, pp. 211-218. Disponible http://www.jstor.org/stable/24369393. Fecha de consulta: 31 de marzo de 2017.

PlanETA (2015): Web oficial. Disponible en: http://www.planeta.es/es/el-grupoplaneta. Fecha de consulta: 17 de mayo de 2017.

$\begin{array}{llllll}\text { Policía NACIONAL } & (8 \text { de }\end{array}$ https://www.policia.es/prensa/20160308_1.html. Fecha de consulta: 22 de marzo de 2017.

PulEo, Alicia (1997) «Mujer, sexualidad y mal en la filosofía contemporánea». En Daimon. Revista de Filosofía, no 14, Murcia: Universidad de Murcia, pp. 167172. 
PulEo, Alicia (2005) «Lo personal es político: el surgimiento del feminismo radical». En Ana de Miguel Álvarez y Celia Amorós Puente (coords.) Teoría feminista: de la Ilustración a la globalización, vol. 2, no 2, pp. 35-67.

RÉmond, René (2002) Historia de los Estados Unidos, París: Presses Universitaries de France (traducción de Publicaciones Cruz O., S.A. con la colaboración de Beatriz Álvarez Klein).

RESINA, Joan Ramon (1997) El cadáver en la cocina: La novela criminal en la cultura del desencanto, Barcelona: Anthropos Editorial.

REVERTER, Sonia (2012) «Los estudios de género y el feminismo». En Rosalía Torrent Esclapés y Sonia Reverter Bañón (eds.), Variaciones sobre género, Castelló de la Plana: Acen, pp. 15-31.

RiverA, María Milagros (1994) Nombrar el mundo en femenino. Pensamiento y teoría feminista, Barcelona: Icaria.

RocafulL, Maribel (2017) Lletra de dona, Castellón: Universitat Jaume I.

RoDríGUEZ, Marie-Soledad (2009) «Las novelas policiacas de Alicia Giménez Bartlett: un nuevo enfoque sobre la identidad femenina». En Pilar Nieva-de la Paz (ed.), Roles de género y cambio social en la literatura española del siglo XX, Amsterdam-Nueva York: Rodopi, pp. 247-262.

Rodríguez Pequeño, Francisco Javier (1995) Ficción y géneros literarios, Madrid: Universidad Autónoma de Madrid.

Romero LóPez, Alicia (2016) «Xénero na novela Y punto de Mercedes Castro». En Boletín Galego de Literatura, no 99/ 2º sem., pp. 5-18. Disponible en: http://www.usc.es/revistas/index.php/bgl/article/view/3234/4117. Fecha de consulta: 28 de abril de 2016.

SAlado, Ana (1 de julio de 2000) «Más allá del misterio». En ABC Cultural. Disponible en: http://hemeroteca.abc.es/nav/Navigate.exe/hemeroteca/madrid/cultural/ 2000/07/01/026.html 
http://hemeroteca.abc.es/nav/Navigate.exe/hemeroteca/madrid/cultural/ 2000/07/01/027.html. Fecha de consulta: 10 de diciembre de 2016.

SALES SAlVAdoR, Dora (2012) «Mujeres y literaturas: nosotras también lo hacemos posible». En Rosalía Torrent Esclapés y Sonia Reverter Bañón (eds.), Variaciones sobre género, Castelló de la Plana: Acen, pp. 135-144.

SAles SAlVAdor, Dora (octubre de 2014) Voces indias contemporáneas: Manju Kapur y Kalpana Swaminathan. Lección inaugural del Máster Universitario en Investigación Aplicada en Estudios Feministas, de Género y Ciudadanía organizado por el Instituto Universitario de Estudios Feministas y de Género «Purificación Escribano». Disponible en: https://www.youtube.com/watch?v=St-Rg8PL0NE. Fecha de consulta: 8 de marzo de 2017.

SAnahuja YlL, Maㅡ Encarna (2002) Cuerpos sexuados, objetos y prehistoria, Madrid: Cátedra.

SÁnCHEZ-VERDEJo PÉREZ, Francisco Javier (2014) «La vampiresa en la sociedad victoriana inglesa: arquetipo de la femme fatale». En Patricia Cifre Wibrow y Manuel González de Ávila (eds.) Cultura de la seducción, Salamanca: Universidad de Salamanca, pp- 225-232.

SÁNCHEZ ZAPATERO, Javier (2014a) La novela europea contemporánea: una aproximación panorámica. En Extravío. Revista electrónica de literatura comparada, n. 7, Valencia: Universitat de València, pp. 10-24. Disponible: https://ojs.uv.es/index.php/extravio/article/view/3032/3342. Fecha de consulta: 20 de marzo de 2017.

SÁNCHEZ ZAPATERO, Javier (2014b) «Domingo Villar: novela negra con sabor gallego». En Revista Sigma, 23, Madrid: UNED, pp. 805-826. Disponible en: http://revistas.uned.es/index.php/signa/article/view/11758/11205.

Fecha de consulta: 20 de mayo de 2017.

SantaulÀria I CAPdeVila, M. Isabel (2005a) «Sexo en Nueva York o cómo ser mujer y no morir en el intento». En Lectora, 11, Barcelona: Universitat de Barcelona, pp. 143-156. Barcelona: Universitat de Barcelona. Disponible en: 
http://revistes.ub.edu/index.php/lectora/article/view/7116/8997. Fecha de consulta: 2 de marzo de 2017.

SANTAULÀRIA I CAPDEVILA, M. Isabel (2005b) «Un viaje al reino de la niebla. La novela de detectives en Gran Bretaña». En Quimera. Revista de literatura, no 259 260, pp. 36-44. Disponible en: http://www.digitaliapublishing.com/visor/21109. Fecha de consulta: 3 de junio de 2017.

SANZ, Marta (2012b) «¿Por qué un detective no se casa jamás?». En Cuadernos Hispanoamericanos, no 741, pp. 43-48. Disponible en: http://www.cervantesvirtual.com/nd/ark:/59851/bmcfj342. Fecha de consulta: 21 de marzo de 2017.

SAU, Victoria (1981) Diccionario ideológico feminista, Barcelona: Icaria Editorial, 1989.

SAU, Victoria (1995) El vacío de la maternidad. Madre no hay más que ninguna, Barcelona: Icaria Editorial.

SERRA, Francesca (2011) Las buenas chicas no leen novelas. Un repaso irónico, crítico e inteligente a la relación de las mujeres con la lectura, Barcelona: Ediciones Península (traducción de Helena Aguilà Ruzola), 2013.

SiLIó, Elisa (2 de febrero de 2008) «Entrevista: La vida cotidiana en la novela policiaca». En El País. Disponible http://elpais.com/diario/2008/02/02/babelia/1201913416_850215.html. Fecha de consulta: 10 de diciembre de 2016.

SILVA, Lorenzo (2008) «Teoría (informal) de la novela benemérita». En ANPE. II Congreso nacional: Multiculturalidad y norma policéntrica: Aplicaciones en el aula de ELE, 26-27/09-2008. Disponible: http://www.mecd.gob.es/dctm/redele/MaterialRedEle/Numeros\%20Especiales/2009_ESP_09_II\%20Congreso\%20Anpe/P lenarias/2009_ESP_09_02Silva.pdf?documentId=0901e72b80e6f1c3. Fecha de consulta: 20 de mayo de 2017. 
ToRras, Meri (2007) «El delito del cuerpo». En Meri Torras (ed.) Cuerpo e identidad, Barcelona: Universitat Autònoma de Barcelona, pp. 11-36.

TORRAS, Meri (2016) «Representaciones, cultura, sexualidad». CuRso Representaciones culturales de las sexualidades, Universitat Autònoma de Barcelona, en Coursera. Junio 2016.

Trotman, Tiffany (2011) The Changing Spanish Family: Essays on New Views in Literature, Cinema and Theater, North Carolina: McFarland.

TruffaUT, François (1966) El cine según Hitchcock, Madrid: Alianza (traducción de Ramón G. Redondo, con la colaboración de Miguel Rubio y Jos Oliver), 1974.

TYRAS, George (2001) «La novela negra española después de 1975: ¿renovación de un género?». En Paul Aubert, La novela en España: siglos XIX-XX, Madrid: Casa de Velázquez, pp. 249-264

TYRAS, George (2002) «Novela negra española encuentros del tercer milenio (con Giménez Bartlett, Silva, Abasolo y Sánchez Soler». En Iberoamericana, vol. 2, no 7, pp. 97-110. Disponible en: https://journals.iai.spkberlin.de/index.php/iberoamericana/article/view/562. Fecha de consulta: 8 de diciembre de 2016.

Urruela, María Cristina (2005) «El “Ángel del Hogar": María Pilar Sinués y la cuestión de la mujer». En Lisa Vollendorf (ed.), Literatura y feminismo en España (siglo XV-XXI), Barcelona: Icaria, pp. 155-170.

Valero Valero, Dori (2015) «Del Baztán a México. A Amaia y a Lupita les gustaba ser policías». En Dora Sales Salvador, Manolo Dos Ramos y Dori Valero Valero. (eds.), Dossiers feministes, 20, Castellón: Universitat Jaume I, pp. 85$99 . \quad$ Disponible h: http://www.erevistes.uji.es/index.php/dossiers/article/view/1748/1800. Fecha de consulta: 20 de mayo de 2017.

VALLÉS CALATRAVA, José R. (1991) La novela criminal española, Granada: Universidad de Granada. 
VÁZquEZ DE PARGA, Salvador (1983) «La novela policiaca en España». En Cuadernos del Norte, nำ 19, mayo-junio, Valencia: Faximil Edicions Digitals, pp. 26-39. Disponible en: http://www.numerossueltos.com/los-cuadernos-del-norte19.html. Fecha de consulta: 31 de marzo de 2017.

VÁZquez Sallés, Daniel (5 de febrero de 2015) «Todo se lo debo a Petra Delicado». Disponible en: http://www.elmundo.es/cataluna/2015/02/05/54d39ab5268e3e3c058b4 574.html. Fecha de consulta: 17 de mayo de 2017.

VENKATARAman, Vijaya (2010) «Mujeres en la novela policial: ¿reafirmación o subversión patriarcal? Reflexiones sobre la serie de Petra Delicado de Alicia Giménez Bartlett». En Hala Awaad y Mariela Insúa (eds.), Textos sin fronteras. Literatura y Sociedad, 2, Pamplona: Ediciones digitales del GRISO, pp. 229-240.

VENTURA, Joaquín (2012) «Género negro en una ciudad patrimonio de la humanidad». En Javier Sánchez Zapatero y Àlex Martín Escribà (eds.), El género negro: el fin de la frontera, A Coruña: Andavira, pp. 135-148.

VERA, Sergio (13 de enero de 2017) «Seishi Yokumizo, el rey de la novela japonesa». En El País. Disponible en: http://cultura.elpais.com/cultura/2017/01/13/elemental/1484285018_85 5104.html. Fecha de consulta: 20 de marzo de 2017.

VIDAL, M. Carmen África (1989) ¿Qué es el posmodernismo?, Alicante: Universidad de Alicante.

ViLLALONGA, Anna Maria (2013) «La novel-la negra catalana actual: la bona salut d'un gènere». En Els Margens, 101, Tardor, pp. 45-68. Disponible en: http://www.raco.cat/index.php/Marges/article/view/295961/384658.

Fecha de consulta: 5 de mayo de 2017.

WIRTH, Linda (2002) Romper el techo de cristal. Las mujeres en los puestos directivos, Madrid: Ministerio de Trabajo y Asuntos Sociales. Disponible en: http://staging.ilo.org/public/libdoc/ilo/2002/102B09_692_span.pdf. Fecha de consulta: 1 de abril de 2017. 
WOLLSTONECRAFT, Mary (1791) Vindicación de los derechos de la mujer, Madrid: Cátedra (traducción de Carmen Martínez Gimeno), 1994.

Woolf, Virginia (1979) Las mujeres y la literatura, Barcelona: Ediciones Lumen (traducción de Andrés Bosch), 1981.

YANG, Chung-Ying (2010) «Petra Delicado y la (de)construcción del género y la identidad». En Hispania. Vol 93 no 4, Walled Lake, MI, American Association of Teachers of Spanish and Portuguese, pp. 594-604. Disponible en: https://www.jstor.org/stable/25758238?seq=1\#page_scan_tab_cont ents. Fecha de consulta: 17 de mayo de 2017. 



\section{Índice de imágenes}

Imagen 1. Humphrey Bogart interpreta a Phillip Marlowe en El sueño eterno (The Big Sleepy, Howard Hawks, 1946). Autoría de la foto: Vintage by López Linares. Disponible en: http://blog.lopezlinares.com/anticuarios/fotografiavintage/page/6/. Fecha de consulta: 7 de junio de 2017.

Imagen 2. Robert Mitchum interpreta a Phillip Marlow en Adiós muñeca (Farewell, My Lovely, Dick Richards, 1975). Autoría de la foto: ITV/REX/Shutterstock. Disponible en: https://therake.com/stories/style/watching-the-detectivesfilm-noirs-enduring-influence-on-style/. Fecha de consulta: 7 de junio de 2017.

Imagen 3. Fotograma de El sueño eterno (The Big Sleep, Howard Hawks, 1946). Disponible en: http://www.jotdown.es/wpcontent/uploads/2013/05/Humphrey-Bogart-y-Lauren-Bacall.jpg. Fecha de consulta: 7 de junio de 2017.

Imagen 4. Fotograma de L.A. Confidential (Curtis Hanson, 1997). Disponible en: http://filmexperience.blogspot.com.es/2010/11/take-three-kimbasinger.html. Fecha de consulta: 7 de junio de 2017.

Imagen 5. Portadas de series de novela negra nórdica (de derecha a izquierda y de arriba abajo). El policía que ríe (Maj Sjöwall y Per Wahbo, 1968), Segundos negros (Karin Fossen, 2002), La princesa de hielo (Camilla Läackberg, 2002), Nemesis (Jo Nesbø, 2002), Aurora Boreal (Åsa Larsson, 2003), El leopardo de las nieves (Peter Mattiessen, 2004), Invierno ártico (Arnaldur Indridason, 2007), The Glass Devil (Helene Tursten, 2009), The Troubled Man (Henning Mankell, 2009), Le noyé dans la glace (Kjell Ola Dahl, 2014). Autoría de la foto: las editoriales que publican los libros.

Imagen 6. Manuel Vázquez Montalbán. Foto de: Santi Cogolludo. Disponible en: http://www.elmundo.es/elmundo/2012/10/01/cultura/1349081726.html. Fechas de consulta: 7 de junio de 2017. 
Imagen 7. Fotograma de El alquimista impaciente (Patricia Ferreira, 2002). Disponible en: http://www.abc.es/fotonoticias/fotos-castillaleon/20150330/fotograma-pelicula-alquimista-impaciente162668009229.html. Fechas de consulta: 7 de junio de 2017.

Imagen 8. Alicia Giménez Bartlett. Autoría de la foto: cedida por la autora a los medios. Disponible en: http://www.diariodenavarra.es/noticias/suplemento/2015/03/17/alicia_gi menez_bartlett_presentara_crimenes_que_olvidare_premio_pepe_carvalho_20 15_199397_1065.html. Fechas de consulta: 7 de junio de2017.

Imagen 9. Fermín Garzón y Petra Delicado.

Imagen 10. Portadas de la saga de Petra Delicado (de derecha a izquierda y de arriba abajo). Ritos de muerte (1996), Días de perros (1997), Mensajeros de la oscuridad (1999), Muertos de papel (2000), Serpientes en el paraíso (2002), Un barco cargado de arroz (2004), Nido vacío (2007), El silencio de los claustros (2009), Nadie quiere saber (2013), Crímenes que no olvidaré (2015). Autoría de la foto: las editoriales que publican los libros.

Imagen 11. Mercedes Castro. Autoría de la foto: Jorge Leal. Disponible en: http://www.laopinioncoruna.es/cultura/2010/04/13/mercedes-castro-vampiros-son-hijos-epoca-hoy-molan/374868.html. Fechas de consulta: 7 de junio de 2017.

Imagen 12. Portadas de las novelas de Mercedes Castro. Y Punto y Mantis. Autoría de la foto: Editorial Alfaguara. Disponible en: http://www.megustaleer.com/. Fechas de consulta: 7 de junio de 2017. 

